DOE/RL-92-29

UC-900

\title{
Hanford 200 Areas Development Plan
}

\author{
C. A. Rinne \\ K. S. Daly
}

Date Published

August 1993

The Goverment reserves for itself and others acting on its behalf a royalty free, nonexclusive, irrevocable, world-wide license for governmental purposes to publish, distribute, translate, duplicate, exhibit, and perform any such data copy righted by the contractor.

Prepared for the U.S. Department of Energy Office of Environmental Restoration and Waste Management

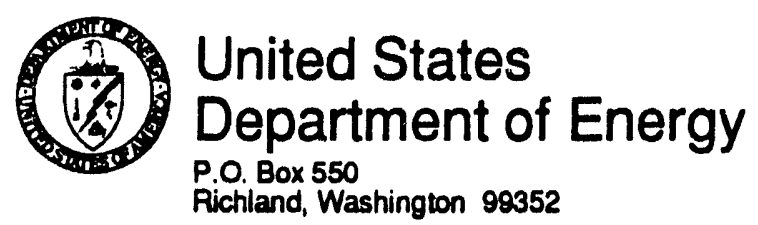


LEGAL DISCLAIMER

This report was prepared as an account of work sponsored by an agency of the United States Government. Neither the United States Government nor any agency therecf, nor any of their employees, nor any of their contractors, subcontraciors or their employees, makes any warranty, express or implied, or assumes any legal liability or responsibility for the accuracy, completeness, or any third party's use or the results of such use of any information, apparatus, producl, or process disclosed, or represents that its use would not intringe privately owned rights. Reference herein to any specific commercial product, process, or service by trade name, trademark, manufacturer, or otherwise, does nol necessarily constitute or imply its endorsement, recommendation, or favoring by the United States Government or any agency thereof or its contractors or subcontractors. The views and opinions of authors expressed herein do not necessarily state of reflect those of the United States Government or any agency thereof.

This report has been reproduced from the best available copy. Available in paper copy and microfiche.

Available to the U.S. Department of Energy

and its contractors from

Office of Scientific and Technical Information

P.O. Box 62

Oak Ridge, TN 37831

(615) 576.8401

Available to the public from the U.S. Department of Commerce National Technical Information Service

5285 Port Royal Road

Springfield, VA 22161

(703) $487-4650$

Printed in the United Slates of Ameriea

DISCLM-1.CHP (1-81) 


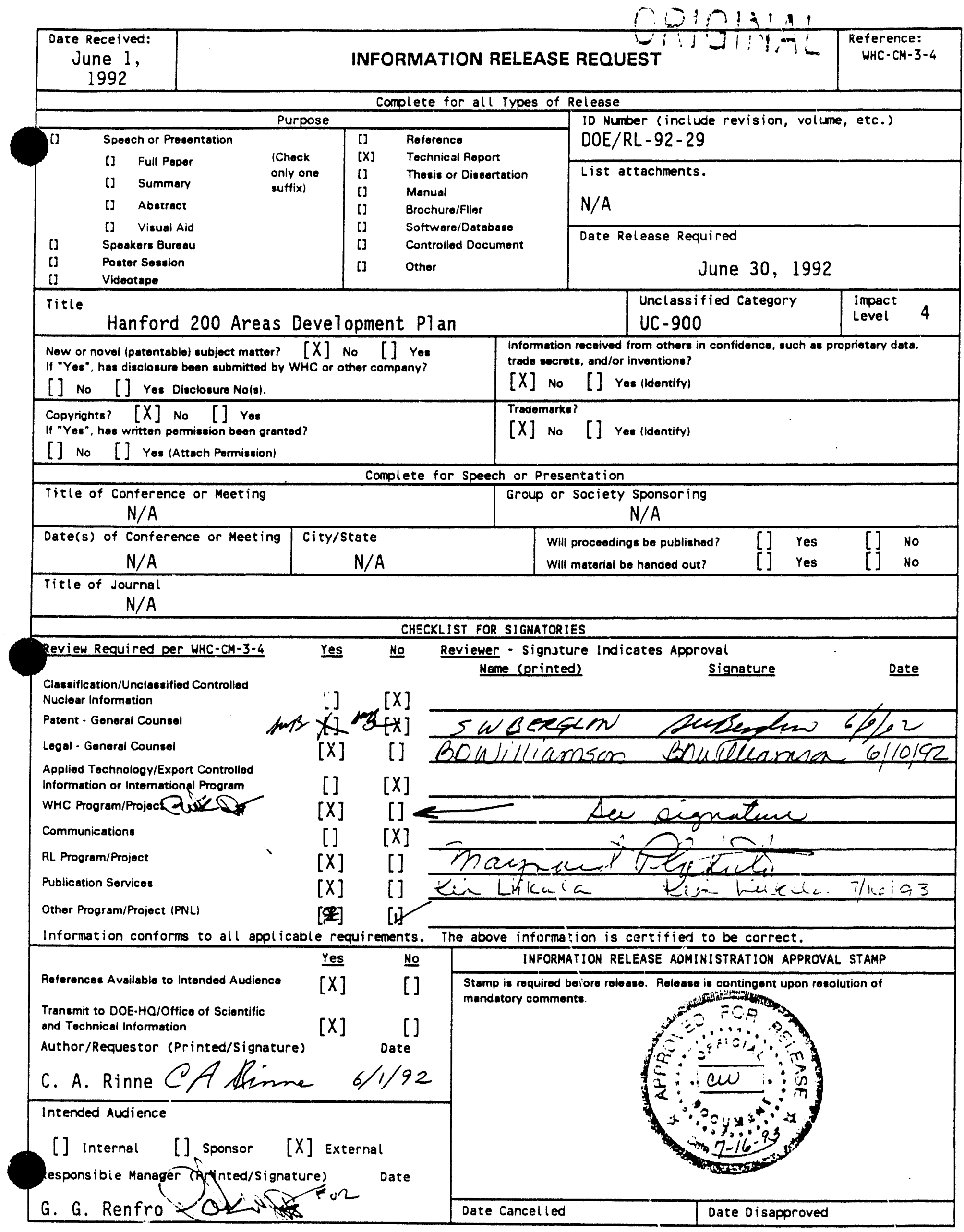


DOE/RL-92-29

Hanford 200 Areas

Development Plan

FOR THE RICHLAND FIELD OFFICE

U.S. Department of Energy Richl and Field Office Richland, Washington

Approved by:
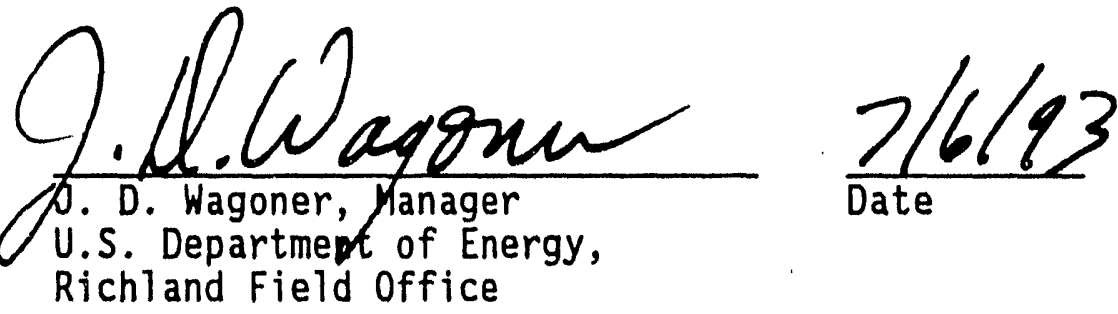

The planning provided in this document is based on information avallable at the close of Fiscal Year 1992. 
This page intentionally left blank. 
This distribution of the Hanford 200 Areas Development Plan will be updated as changes are made to the document. A Record of Revision Form (Form Number A-7320-005) will be used to provide updates to the Plan. Informational copies of the Development Plan are also available. These informational copies will not be updated as changes are made to the document. To be put on distribution to receive an informational copy, please contact the Westinghouse Hanford Company Operations Support Services Site Planning Group.

\section{NATIONAL ENVIRONMENTAL POLICY ACT DISCLAIMER:}

This document does not direct federal actions. Its purpose is to guide the physical development of the 200 Areas by identifying issues and influencing programmatic planning. Individual federal actions taken subsequent to the release of this document may require evaluations under the National Environmental Policy Act of 1969. 
$\bullet$

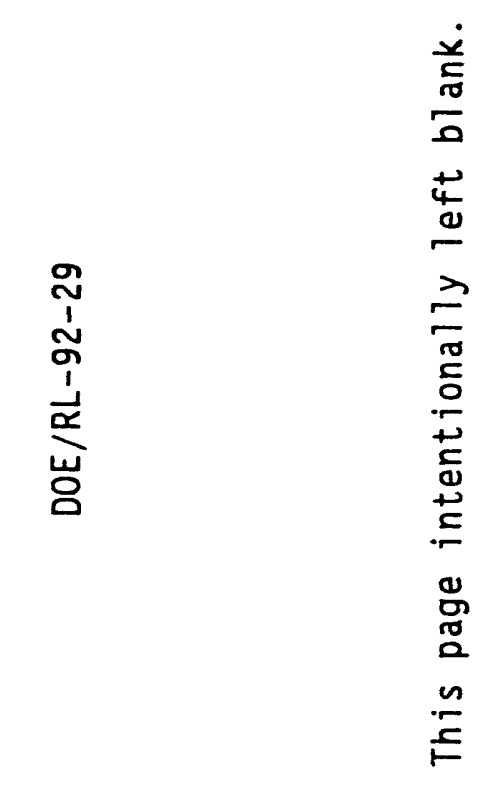


$D O E / R L-92-29$

\section{CONTENTS}

1.0 INTRODUCTION ....................... . . . . . . .

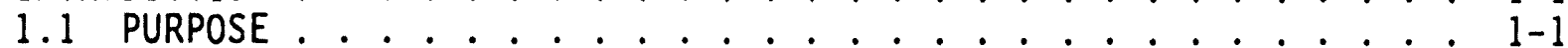

1.2 SCOPE . . . . . . . . . . . . . . . 1-1

1.3 MAJOR PLANNING ISSUES .................. . . . . . . . . .

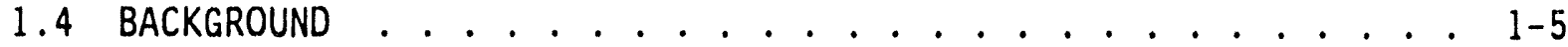

2.0 PLANNING ANALYSIS, EXISTING CONDITIONS, AND PROJECTIONS . . . . . 2-1

2.1 MISSIONS ..................... . 2-1

2.1.1 Environmental Restoration .......... 2-3

2.1.2 Tank Waste Remediation System .......... 2-4

2.1.3 Solid and Liquid Waste Disposal . . . . . . . . 2-6

2.1.4 Nuclear Facilities . . . . . . . . . . . . 2-8

2.1 .5 Science and Technology ............ 2-. 2-

2.1 .6 Site Support ................. 2-9

2.1 .7 Special Initiatives . . . . . . . . . . 2-10

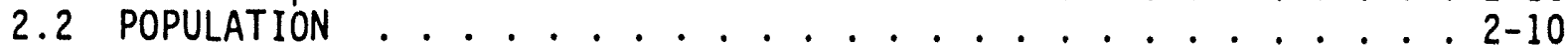

2.3 FACILITIES AND INFRASTRUCTURE . . . . . . . . . . 2-12

2.3.1 Facilities............. . 2-12

2.3.2 Line Item Projects . . . . . . . . . . . 2-20

2.3.3 Infrastructure . . . . . . . . . . . . 2-20

2.3.4 Developable Lands .............. . 2-52

2.4 SAFEGUARDS AND SECURITY . . . . . . . . . . . . 2-54

2.4.1 Physical Security . . . . . . . . . . . . 2-54

2.4.2 Significant Nuclear Inventories . . . . . . . 2-57

2.5 ENVIRONMENTAL ACTIVITIES . . . . . . . . . . . . 2-57

2.5.1 Hanford Federal Facility Agreement and Consent Order . . 2-57

2.5.2 Operable Units . . . . . . . . . . . . 2-57

2.5.3 Expedited Response Actions ......... 2-65

2.5.4 Aggregate Area Management Study Reports . . . . . . . 2-65

2.5.5 Environmental Permitting Activities . . . . . . . 2-68

2.6 PLANNING INTEGRATION ................ 2- . . . . . .

2.6.1 Responsibilities and Internal Coordination..... 2-70

2.6.2 State and Local Agencies ......... 2-70

2.6.3 Hanford Site Integrated Planning Process and 1992

2.7 LAND USE Hanford Mission Plan . . . . . . . . . . . . . . . . . . 2-71

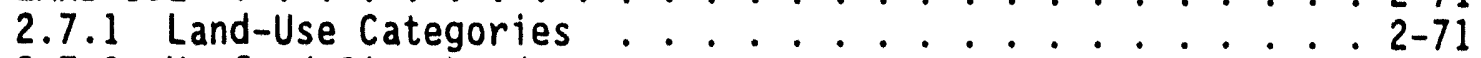

2.7.2 Hanford Site Land-Use Category Definitions . . . . . 2-73

2.7.3 200 Areas Existing Land-Use Plan .......... . 2-75

2.7.4 200 Areas Long-Range Land-Use Plan . . . . . . . . 2-77

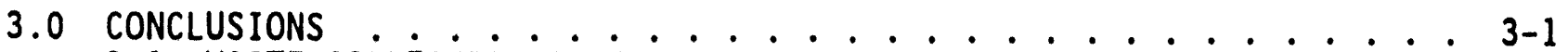

3.1 WASTE COLLECTION OR TRANSFER LINES $\ldots 3-1$

3.2 WASTE SAMPLING AND CHARACTERIZATION FACILITY $\ldots \ldots \ldots . \cdots 3-1$

3.3 INFRASTRUCTURE ISSUES . . . . . . . . . . . . . 3-1

4.0 MASTER PLANNING ..................... . . . . . . . . . .

4.1 INDIVIDUAL MASTER PLAN DRAWINGS ............. 4 4-1

4.1.1 200 East Area . . . . . . . . . . . . . . . . . . 4-1

4.1 .2200 Area Corridor . . . . . . . . . . . . 4-8

4.1 .3200 West Area . . . . . . . . . . . . . 4-8 


\section{CONTENTS (cont)}

4.2 200 AREAS MASTER PLAN . . . . . . . . . . . . . . . . . . 4-11

4.3 DEVELOPMENT STANDARDS . . . . . . . . . . . . . . . . . . 4-11

4.3.1 Architectural Standards . . . . . . . . . . . . . 4-11

4.3.2 Site Development Standards . . . . . . . . . . . . 4-15

4.3.3 Setback Standards ................. . . 4-15

4.3.4 Landscaping Standards .. . . . . . . . . . . . . . . . 4-15

4.3.5 Energy Conservation Standards . . . . . . . . . . 4-16

4.4 NEW INITIATIVES .................... . . . . . . . . . . . .

5.0 REFERENCES . . . . . . . . . . . . . . 5-1

6.0 BIBLIOGRAPHY . . . . . . . . . . . . . . . 6-1

\section{APPENDIXES :}

A. 200 AREAS FACILITIES AND GENERAL LAYOUT . . . . . . . . . . . A-1

B. PROJECTED POPULATIONS BY AREA . . . . . . . . . . . . . . . B-1

C. SITE INFORMATION . . . . . . . . . . . . . . . . . . . . . . C C-1

D. PACIFIC NORTHWEST LABORATORY PROPOSED CONSTRUCTION

RESTRICTIONS IN CORRIDOR AREA ................ . D-1 


\section{LIST OF FIGURES}

1-1 Location of the Hanford Site and the 200 Areas ......... 1-2

2-1 200 Area Decommissioning Projects . . . . . . . . . . . . 2-18

2-2 Construction Projects Planned in the 200 East Area . . . . . . . 2-29

2-3 Construction Projects Planned in the 200 Area Corridor . . . . . . 2-30

2-4 Construction Projects Planned in the 200 West Area . . . . . 2-31

2-5 Existing Access to the 200 Areas ............. 2-33

2-6 Existing Roads and Rail in the 200 Areas . . . . . . . . 2-34

2-7 Proposed Primary Road Development Between and Around the 200 Areas . . . . . . . . . . . . . . . . 2-35

2-8 Future 200 East Area Roads and Rail . . . . . . . . . . . . 2-37

2-9 Future 200 West Area Roads and Rail . . . . . . . . . . . 2-38

2-10 Conceptual Plan for Roads and Rail in 200 Area Corridor . . . . . 2-39

2-11 Existing and Planned 200 East Water System . . . . . . . . . 2-40

2-12 Existing and Planned 200 West Water System ......... 2-41

2-13 Existing and Planned Telecommunications in the 200 East Area . . . 2-44

2-14 Existing and Planned Telecommunications in the 200 West Area . . 2-45

2-15 Existing and Planned Electrical Power Distribution in the 200 East Area . . . . . . . . . . . . . . . . . 2-46

2-16 Existing and Planned Electrical Power Distribution in the 200 West Area . . . . . . . . . . . . . . . . . 2-47

2-17 Existing and Planned Steam Distribution in the 200 East Area . . 2-49

2-18 Existing and Planned Steam Distribution in the 200 West Area . . 2-50

2-19 Proposed 200 Areas Sanitary Waste Collection System . . . . . 2-51

2-20 200 Areas Developable Lands . . . . . . . . . . . . 2-53

2-21 Existing 200 Areas Physical Security . . . . . . . . . 2-55

2-22 200 East Area Operable Units . . . . . . . . . . . . . 2-60

2-23 200 West Area Operable Units . . . . . . . . . . . 2-61 


\section{LIST OF FIGURES (cont)}

2-24600 Area Operable Units . . . . . . . . . . . . . . . . . 2-62

2-25 200 East Aggregate Areas . . . . . . . . . . . . . . . . 2-66

2-26 200 West Aggregate Areas . . . . . . . . . . . . . . . 2-67

2-27 Development Planning Integration . . . . . . . . . . . . 2-72

2-28 200 Areas Existing Land-Use Plan . . . . . . . . . . . . 2-76

2-29 200 Areas Long-Range Land-Use Plan . . . . . . . . . . . . . 2-78

4-1 200 East Core Area Master Plan . . . . . . . . . . . . . . 4-2

4-2 200 East Core Area Master Plan--Utilities . . . . . . . . . . . . 4-3

4-3 241-A Tank Farms and Grout Treatment and Disposal Master Plan . . 4-5

4-4 Treated Effluent Disposal Area Master Plan . . . . . . . . . . . . 4-7

4-5 Collection System for Treated Effluent Disposal Facility . . . . 4-9

4-6 Tank Waste Remediation System Development Conceptual Plan . . . . 4-10

4-7 Hanford Central Waste Complex Master Plan . . . . . . . . . . . 4-12

4-8 Hanford Central Waste Complex--Utilities Master Plan . . . . . . 4-13

4-9 200 Areas Master Plan . . . . . . . . . . . . . . . . . . . 4-14 


\section{LIST OF TABLES}

2-1 200 Areas Projected Population (as of September 1991) . . . . . 2-11

2-2 200 East Area Inadequate Facilities List . . . . . . . . . . 2-14

2-3 200 West Area Inadequate Facilities List . . . . . . . . . . 2-15

2-4 Decommissioning Projects . . . . . . . . . . . . . 2-16

2-5 200 Areas' Facilities Planned to be Transferred to

Decontamination and Decommissioning within the Next 10 Years . . 2-19

2-6 200 Areas Construction Projects (More than \$1.2 Million) . . . 2-21

2-7 200 East Area Significant Nuclear Inventories . . . . . . . . . 2-58

2-8 200 West Area Significant Nuclear Inventories . . . . . . . . 2-59

2-9 200 East Area Operable Units . . . . . . . . . . . . . . 2-63

2-10 200 West Area Operable Units . . . . . . . . . . . . . . 2-64

2-11 200 Area Resource Conservation and Recovery Act.

Permitting Status ............... 2-. . . . . . . . . 


\section{LIST OF TERMS}

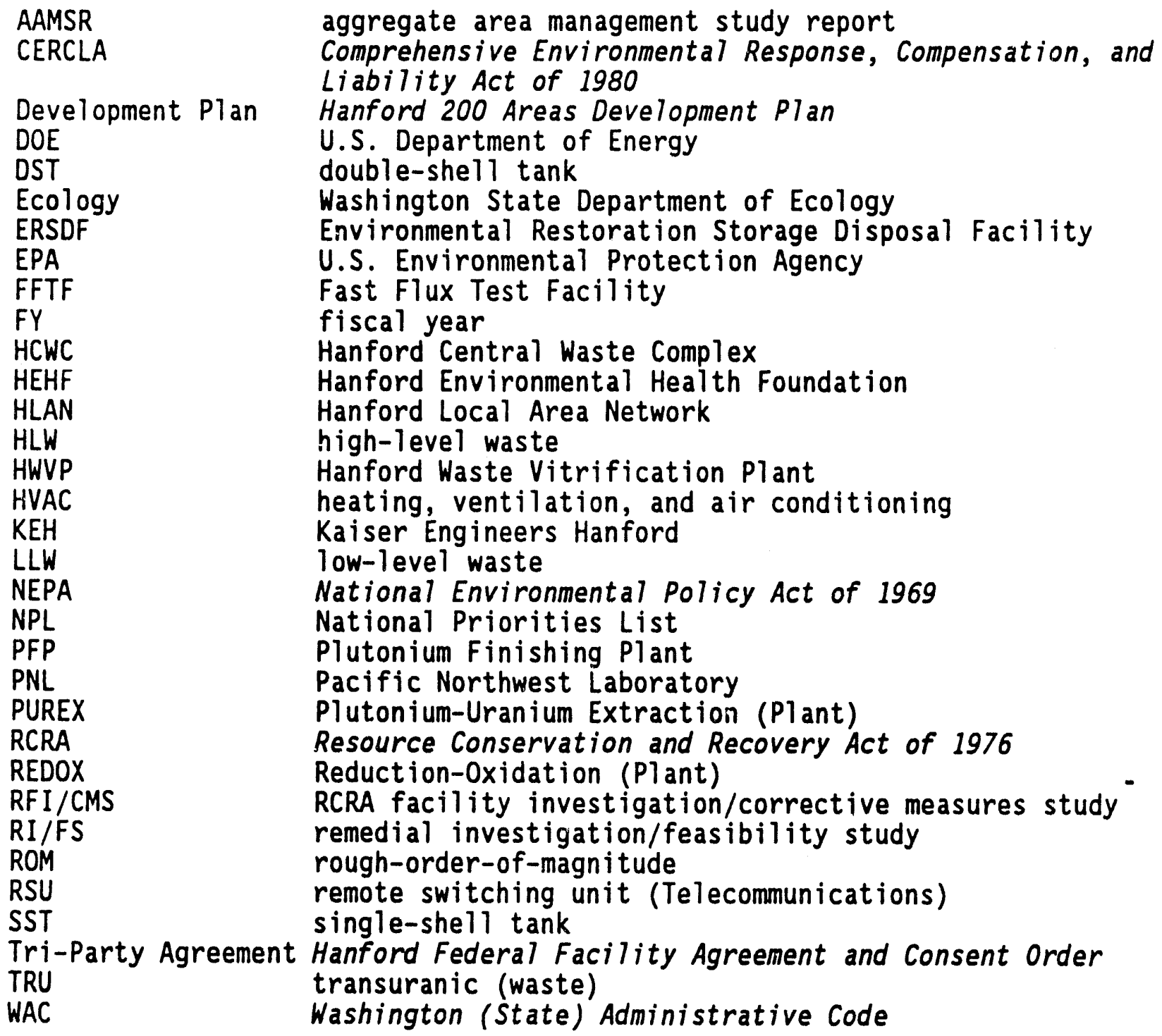


DOE/RL-92-29

HANFORD 200 AREAS DEVELOPMENT PLAN

\subsection{INTRODUCTION}

\subsection{PURPOSE}

The purpose of the Hanford 200 Areas Development Plan (Development Plan) is to guide the physical development of the 200 Areas (which refers to the 200 East Area, 200 West Area, and 200 Area Corridor, located between the 200 East and 200 West Areas) (Figure 1-1) in accordance with U.S. Department of Energy (DOE) Order 4320.1B (DOE 1991a) by performing the following:

- Establishing a land-use plan and setting land-use categories that meet the needs of existing and proposed activities

- Coordinating existing, 5-year, and long-range development plans and guiding growth in accordance with those plans

- Establishing development guidelines to encourage cost-effective development and minimize conflicts between adjacent activities

- Identifying site development issues that need further analysis

- Integrating program plans with development plans to ensure a logical progression of development

- Coordinate DOE plans with other agencies [i.e., Washington State Department of Ecology (Ecology) and U.S. Environmental Protection Agency (EPA)]

- Being a support document to the Hanford Site Development Plan (DOE-RL 1990a) (parent document) and providing technical site information relative to the 200 Areas.

\subsection{SCOPE}

This Development Plan discusses the use of 200 Areas land and facilities in the foreseeable future. It develops a picture of what is currently known and anticipated. As time passes, this document will be updated to reflect changed conditions and new concepts. The long-range picture is created by setting a baseline of what exists today, projecting what will be accomplished over the next 5 years, and then developing a vision of what might occur through completion of all Hanford Federal Facility Agreement and Consent Order (Tri-Party Agreement) (Ecology et al. 1990) milestones by the year 2018. The following criteria have been developed as a guide for establishing the content and level of detail presented in the Development Plan.

- The Development Plan should be flexible to support its use in making decisions concerning broad programmatic issues. 
Figure 1-1. Location of the Hanford Site and the 200 Areas.

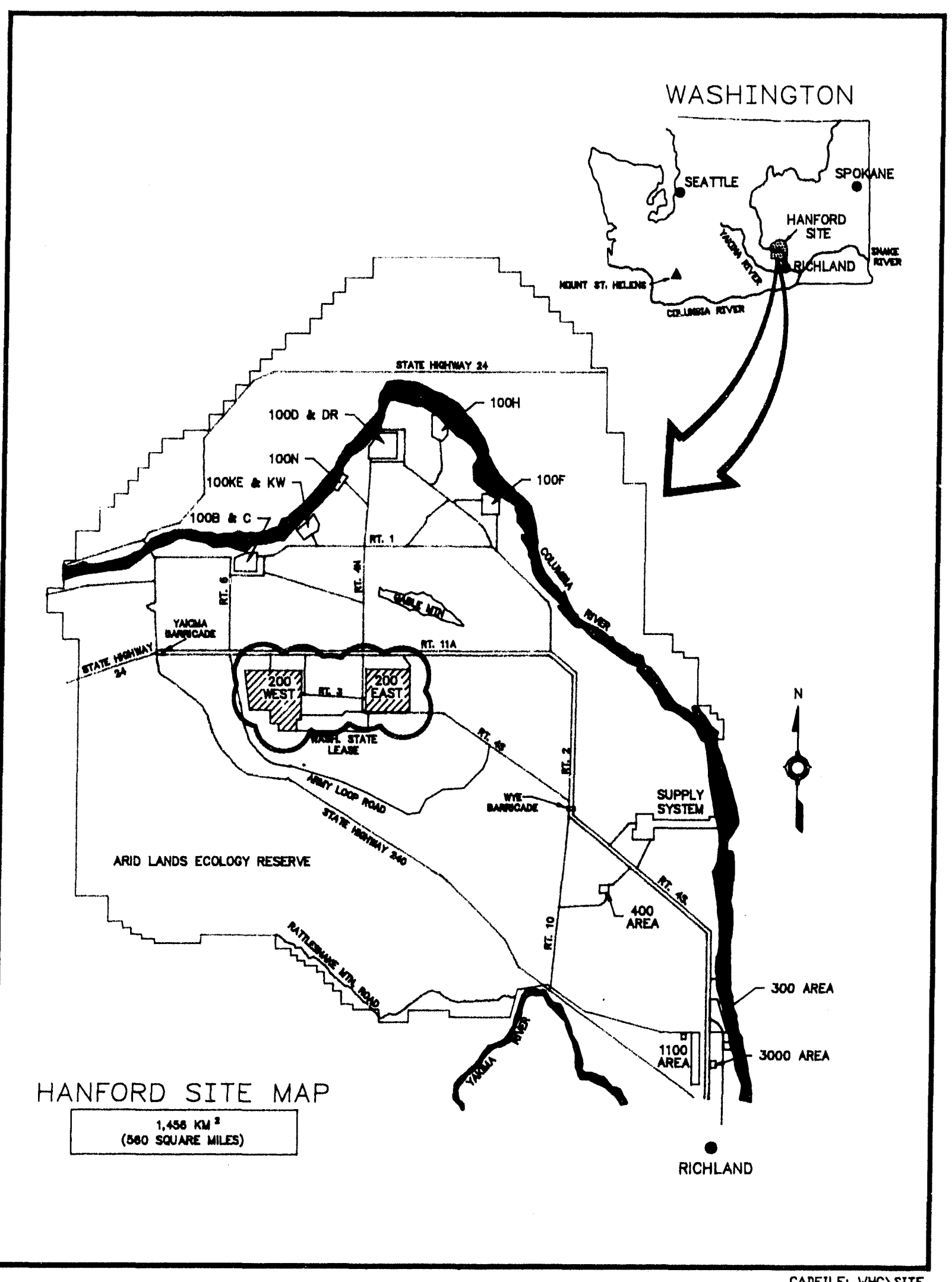

CADFILEI WHCISITE 
$\mathrm{DOE} / \mathrm{RL}-92-29$

- The Development Plan should take the initiative in presenting concepts and standards for development.

- The Development Plan should identify issues and course(s) of action to resolve them.

The analysis presented in the Development Plan is based on existing and future mission activities within the 200 Areas.

Results of the Hanford Site remedial action environmental impact statement will ultimately be incorporated into all site and area development plans. Public and other agency participation through this environmental impact statement process are expected to change or modify elements of these plans. Additionally, the DOE, Richland Field Office (RL) is using an integrated planning process that identifies how Site and area development plans are integrated with the 1992 Hanford Mission Plan (RL 1992a) and the overall Hanford Site integrated planning process.

The DOE has requested proposals for an environmental restoration contract to manage environmental activities at the Hanford Site. The impact of an Environmental Restoration and Management Contractor on 1 and use and facilities planning for the 200 Areas is not yet defined and is not addressed in this Development Plan.

\subsection{MAJOR PLANNING ISSUES}

The major planning issues broadly summarize the conclusions drawn from this document. The following major planning issues focus on developing the required facilities and infrastructure to achieve the 200 Areas' missions.

1. Treatment and discosal facilities for the low-level waste (LLW) fraction of singie-shell tank (SST) wastes have yet to be selected. Depending on the method chosen for closing the SSTs and the process chosen for treating the low-level part of the waste (if retrieved), the space needed could be between "none" and "over 800 acres." Two potential locations for $L L W$ treatment and disposal have been identified for the maximum area scenario; one just south of the 200 East Area and one north of Route 3 in the 200 Area Corridor.

2. The 1992 Hanford Mission Plan assumes a record of decision will select transferring the production reactor graphite cores to the 200 Areas as solid waste. The mission planning basis should include acceptance and disposal of these cores.

3. A decision on natural gas as the primary energy source for processing and heating needs to be made. Some studies indicate that providing natural gas to the 200 Areas would be the beginning of significant reductions in energy usage both in processing and heating. This is also attractive in light of public concern over coal plant stack emissions, ash disposal issues, and the Northwest's electrical power supply. 
4. Recently, there has been added emphasis on locating support personnel close to where the mission activity is taking place. For instance, office and shop facilities are being planned at the tank farms, at the Effluent Treatment Facility, and at the Hanford Central Waste Complex (HCWC). The benefits of placing major concentrations of employees adjacent to waste handling activities need to be compared with the responsibility to keep personnel exposure to hazards as low as reasonably achievable. Specifically, placing additional personnel adjacent to waste handling facilities needs to be evaluated for potential risks to employees resulting from their relocation (DOE Order 6430.1A) (DOE 1989) and need to be evaluated for impacts to existing safety analyses (DOE Order 5480.21) (DOE 1991b). Other considerations could be additional traffic to the 200 Areas and the environmental effect of this commuting traffic.

5. Significant reconstruction and upgrade of infrastructure systems will be needed to support the planned development of new work centers and an incressing number of staff members.

6. Coordination of numerous construction and cleanup projects within the 200 Areas over the next 10 to 20 yaars will present a significant challenge. Currently proposed activities will bring 2,000 to 3,000 construction workers into the 200 Areas as well as over 1,000 DOE and contractor employees. At the same time, burial ground closure and remedial action activities may close off some existing transportation routes. Careful project planning will be required to avoid significant conflicts and ensure safe access and operations.

7. Currently, the Pacific Northwest Laboratory (PNL) has requested that construction be restricted within the 200 Area Corridor to preserve land used in meteorological field measurement programs (see Appendix D). But in the cleanup of the Hanford Site, large tracts of usable land in and around the 200 Area, which are scarce, are needed for the processing and disposal of waste. Centralized waste disposal activities in the 200 Area would require encroaching into PNL's proposed construction restrictive zone.

8. Hanford Site contractors are experiencing a major office space shortfall, approximately 2,700 work stations short, including inadequate space, at the end of fiscal year (FY) 1992. By 1997, projections indicate an additional 2,650 work stations will be needed. The current shortfall in the 200 Areas is greater than 1,000 work stations, including inadequate space. Requirements for an additional 870 work stations are expected by the end of FY 1997. As new missions and facilities are planned, projects for increased work stations should be considered to relieve the existing overcrowding, replace inadequate office space, and compensate for future growth.

9. Safety analyses (but not necessarily safety analyses reports) will be required for all construction, decommission and decontamination, and cleanup projects. 
10. Facilities have yet to be identified for the following:

- Disposal form conversion of irradiated fuel and cesium and strontium capsules. Options for disposal form include overpacking the existing fuel and capsules, vitrify them as separate glass $\mathrm{plant}$ feed, processing and blending their material with other glass plant feed material to minimize the quantity of vitrified material, and processing them to form insoluble materials which are packaged separately for disposal. These separately packaged materials could have beneficial use before disposal.

- Large volume soil contamination partitioning, soil leaching, and leachate contamination partitioning.

11. A disposal method needs to be identified for the treated effluent from the proposed sanitary waste collection and treatment facilities. Options include the following:

- Recycling

- Soil column discharge

- Surface irrigation to grow shallow-rooted plants for soil stabilization.

\subsection{BACKGROUND}

The Hanford Site occupies a mostly flat, semiarid site of approximately $1,456 \mathrm{~km}^{2}\left(560 \mathrm{mi}^{2}\right)$ in the southeastern portion of Washington State. The Hanford Site is owned by the U.S. Government and administered by the DOE.

The 200 Areas occupy approximately $44 \mathrm{~km}^{2}\left(17 \mathrm{mi}^{2}\right)$ on an expansive plateau near the center of the Hanford Site. The 200 East Area, 200 West Area, and 200 Area Corridor (the land between the 200 East and West Areas) form the 200 Areas.

Washington State has a 99-year lease on 404.7 hectares (1,000 acres) along the south border of the "corridor" area. The State has subleased 40.5 hectares ( 100 acres) to California Nuclear, Inc. (U.S. Ecology), who operates this site for the disposal of commercial low-level nuciear waste. While it is not officially part of the 200 Areas, state leased land is served by the 200 Areas infrastructure. For this reason, impacts from activities on the leased land on the 200 Areas infrastructure are considered in this plan. See Appendix $C$ for additional Site information. 
DOE/RL-92-29

This page intentionally left blank. 


\subsection{PLANNING ANALYSIS, EXISTING CONDITIONS, AND PROJECTIONS}

The next three sections (2.0 through 4.0) provide the rationale and framework for the land-use plans and development concepts outlined in this document. The plans are based on an analysis of existing conditions and projected activities. A number of goals, objectives, planning issues, and conclusions are developed from this analysis and will be used as a framework for future development.

This section discusses the existing conditions and projected activities of the 200 Areas. This section is divided into seven areas:

- Missions

- Population

- Facilities and infrastructure

- Safeguards and security

- Environmental activities

- Planning integration

- Land use.

Section 2.1, "Missions," is further divided into the following seven mission area activities:

- Environmental restoration

- Tank waste remediation system

- Solid and liquid waste disposal

- Nuclear facilities

- Science and technology

- Site support

- Special initiatives.

\subsection{MISSIONS}

Many events described in the Tri-Party Agreement could significantly affect Site missions described in the Strategic Plan (RL 1992b). Development of the 200 Areas must support these missions and be flexible enough to respond to change as Hanford Site missions evolve. As described in the 1992 Hanford Mission Plan (RL 1992a), development of a firm technical baseline for disposition of Hanford Site wastes is limited by decisions that must be made as part of the National Environmental Policy Act of 1969 (NEPA) process. The Final Environmental Impact Statement, Disposal of Hanford Defense High-Level Transuranic and Tank Wastes, Hanford Site, Richland, Washington (DOE 1987) describes the primary disposition decisions completed for Hanford Site wastes. The record of decision (DOE 1988) based on this environmental impact statement covers disposition of the following:

- Liquid waste contained in double-shell tanks (DST)

- Retrievably stored transuranic (TRU) solid waste stored in the 200 Areas 
- Pre-1970 buried suspect TRU-contaminated solid waste in the 618-11 Burial Ground

- Newly generated TRU solid waste

- Cesium and strontium capsules.

Material disposition plans are generally undefined for the remaining wastes at this time, including SST waste, pre-1970 buried TRU solid waste, nuclear materials, contaminated soils, contaminated groundwater, and surplus facilities.

To evaluate the potential impacts from completing the disposition of all Hanford Site wastes, the Hanford Integrated Planning Process Strategic Systems Analysis Task Team developed an interim technical baseline in two parts. First, a core technical baseline was developed based on currently available decisions (DOE 1987). Second, a 1992 planning basis was developed by anticipating certain results of key decisions that ultimately must be made via the NEPA process.

The 1992 planning basis is a plan to address the entire Hanford Site inventory of materials and integrate the cleanup actions into a single systein. In general, the 1992 planning basis uses the 200 Areas and vicinity as a collection and disposal area for the entire inventory of Site materials. The 1992 planning basis focuses on converting all wastes into stable solid materials that can be disposed of either onsite or offsite, or shipped offsite as usable materials.

Cleanup activities in the 1992 planning basis focus on removing materials from other areas (especially the 100 Areas and the 300 Area) to satisfy future use of soils in those areas. Groundwater cleanup activities are directed toward protecting the Columbia River from contamination that would exceed drinking water standards, while requiring institutional controls restricting groundwater use throughout portions of the site for an indeterminate time period. The 200 Areas are assumed to be maintained in perpetuity for waste disposal and other DOE activities.

The following key assumptions were used to develop long-range mission projections and assess future needs for the 200 Areas.

- The 200 Areas plateau will remain under Federal control throughout the planning period.

- Radioactive wastes will be collected in the 200 Areas as cleanup progresses in other areas of the Hanford Site.

- The 200 Areas will be cleaned up to meet criteria for in situ disposal. Criteria has or will be established by DOE and Washington State regulations or via the Hanford Site remedial action environmental impact statement process.

- Management of risks associated with historical defense nuclear materials production will continue to be a major public issue. 
Public concern will continue to focus on environmental, health, and safety impacts of potentially hazardous pollutants and wastes from Hanford Site activities.

- Activities will be initiated and implemented to ensure compliance with the terms and objectives of the Tri-Party Agreement (Ecology et a1. 1990).

- Waste management and environmental restoration activities will increase.

- Production of special nuclear material will not restart. Some special nuclear material may be produced as a residual byproduct of stabilization and cleanup activities.

- Plutonium production facilities will be decontaminated and decommissioned.

- A viable infrastructure will be needed in the 200 Areas to support the work defined and scheduled in the Tri-Party Agreement (Ecology et a1. 1990).

\subsubsection{Environmental Restoration}

The following section describes how the environmental restoration mission would be handled by the 1992 planning basis. The environmental restoration mission area will be influenced by the ultimate Hanford Site remedial action environmental impact statement and cleanup decisions more than any other mission area. Therefore, the 1992 planning basis described may be subject to major modifications when decisions are established.

Remedial Actions. For the 1992 planning basis, contaminated soils outside the 200 Areas are excavated and treated with simple classification process steps to remove the contaminated soil. This separation will be done near the excavation sites and convert the bulk of the soil into material suitable for return to excavation backfill. The smaller soil volume with concentrated contaminants is transferred to a central facility in the 200 Areas for stabilization and disposal.

The 1992 planning basis for contaminated groundwater is primarily directed toward protecting the Columbia River. Groundwater remediation activities will take into account the impacts of liquid effluent disposal plans, which were developed by the liquid effluent mission area. Restrictions on groundwater use throughout major portions of the Site, including the 200 Areas, are assumed to be maintained in perpetuity for planning purposes. The timeframe projected to achieve general use of groundwater outside the 200 Areas is long enough to be equivalent to perpetual control of the groundwater.

The 1992 planning basis is the same for solid waste located in active and inactive waste sites. In general, all TRU solid waste will be retrieved for 
treatment and ultimate disposal offsite. Solid LLW outside the 200 Areas will be retrieved for diuposal in systems within the 200 Areas, and solid LLW within the 200 Areas will be disposed of in place.

The 1992 planning basis for SST structures and waste residuals dispositioned by the remedial action mission area will emphasize in situ disposal of the structures. This assumes that the tank waste remediation systen mission area will complete waste material retrieval to the extent required by established in situ disposal criteria. Because the SSTs are located within the 200 Areas, in situ disposition of the residuals will comply with the concept of collecting and managing wastes in the 200 Areas.

Decontamination and Decommissioning. The 1992 planning bas is for facility decontamination and decommissioning uses a combination of alternatives. Facility decontamination followed by complete demolition is planned for most facilities. For selected facilities in the 200 Areas, decommissioning options that either demolish or result in partial decontamination with in situ disposal of below-grade structures are available. For larger radioactively contaminated facilities in the 200 Areas, entombment of major process structures such as B Plant, $T$ Plant, $U$ Plant, Plutonium-Uranium Extraction (PUREX) Plant, Reduction-0xidation (REDOX) Plant, and Plutonium Finishing Plant (PFP) is assumed to be more likely than demolition.

\section{Actions Needed to Comolete Environmental Restoration Mission}

- Achieve remediation of Comprehensive Environmental Response Compensation, and Liability Act of 1980 (CERCLA)/Resource Conservation and Recovery Act of 1976 (RCRA) Past Practice operable unit:.

- Make decisions on acceptable clean up standards to achieve performance assessment requirements.

- Designate areas for wastes collected from onsite restoration actions. The Environmental Restoration Storage and Disposal Facility (ERSDF) is planned to meet this need.

- Cap and close the burial grounds.

- Replace roads along burial grounds because closure caps will cover adjacent roads.

- Demolish most surplus ancillary and support structures. Finalize decisions for disposal of large surplus contaminated concrete structures.

\subsubsection{Tank Waste Remediation System}

It is anticipated that each operational facility supporting interim waste storage (i.e., the 242-A Evaporator/Crystallizer, tank car unloading facility) will be deactivated by waste tank safety and operations before transfer of these facilities to the Environmental Restoration Program. 
Double-Shell Tank Waste Disposal. The 1992 planning basis for DSTs is retrieval of all tank waste. Neutralized cladding removal, neutralized current acid, PFP, and complexed concentrate wastes are pretreated to produce high-level waste (HLW), LLW, and condensate fractions for disposal. The HLW fraction is converted to a glass form and packaged for interim storage onsite until eventual geologic disposal. The LLW fraction is converted to a solid grout form for onsite disposal. Condensates are disposed of in the treated effluent disposal system in the solid and liquid waste mission area. The DST systems, internal tank equipment, and any associated contaminated soils would be disposed of in situ, assuming that waste material is retrieved to the extent required to comply with in situ disposal criteria. This applies to both existing and future DSTs.

The 1992 planning basis for cesium and strontium capsules is that they will be disposed of in a geologic repository as follows: (1) overpacking the capsules in repository disposal canisters, or (2) by incorporating them in borosilicate glass in the Hanford Waste Vitrification Plant (HWVP); for HWVP the $\mathrm{CSCl}$ and $\mathrm{SrF}_{2}$ would be removed from the capsules and blended with pretreated tank waste to make a feed suitable for vitrification. Low-heat vitrification plant feeds, such as those originating with pretreatment of complexed concentrate or PFP waste, are candidates for blend stock to minimize the number of glass canisters created for disposal. Both forms of disposal will be deposited in a geologic repository as one becomes avallable.

Single-Shell Tank Waste Disposal. The 1992 planning bas is is retrieval of tank waste to the extent required for in situ disposal, followed by interim storage in DSTs, and pretreatment to separate the waste into HLW, LLW, and condensate fractions. The HLW fraction is converted to glass for geologic disposal; the LLW fraction is converted to a solid form for onsite disposal; and the condensate is transferred to the treated effluent disposal system. Disposition activities for the SST systems, internal tank equipment, and associated contaminated soils are outlined in the environmental restoration mission area.

\section{Actions Needed to Complete Tank Waste Remediation System Mission}

- Develop and construct tank waste retrieval facilities.

- Build pretreatment facilities to resolve waste tank safety issues and provide feed material to HWVP and Grout Treatment Facility.

- Build and operate the HWVP.

- Build multipurpose storage facilities to store glass from HWVP, irradiated fuel, special nuclear material, and cesium and strontium capsules.

- Build additional tank farms (the total number of new tanks could range from 12 to 90 ).

- Build up to 43 additional grout vaults to support the disposal of LLW from DSTs. 
- Build a LLW treatment and disposal facility and up to 139 vaults to dispose of LLW from SSTs. The treatment process selected will have a major impact on the amount of 1 and required (by as much as a factor of six).

- Replace the 242-A Evaporator/Crystallizer.

- Provide the supporting infrastructure (i.e., pipelines, control systems, transiortation, utilities, communications).

- Complete closure of existing SSTs and DSTs.

\subsubsection{Solid and Liquid Waste Disposal}

Solid Waste. It is assumed that offsite geologic repositories will be available for the disposal of HLW and TRU waste from the Hanford Site. Uncertainties in the availability of offsite treatment and disposal facilities will require onsite interim storage of these wastes. Note, cleanup actions will not be considered complete until these interim storage areas are emptied by offsite shipments. The 1992 planning basis for solid waste is summarized as follows.

- Transuranic and Transuranic-Mixed Solid Waste--Pre-1970, buried suspect TRU-contaminated waste is retrieved for treatment along with stored and newly generated TRU and TRU-mixed solid waste. The waste is treated to segregate the TRU and TRU-mixed fractions from materials in other waste groups. The TRU and TRU-mixed fractions are converted to a disposal form by simple stabilization and volume reduction processes, repackaged, and transferred to a storage facility for ultimate shipment offsite to the Waste Isolation Pilot Plant in New Mexico. Uncertainty about if and when the Waste Isolation Pilot Plant will receive Hanford Site waste makes it prudent to plan for storing this waste onsite through the planning period (20 to $30 \mathrm{yr}$ ).

- Low-Level Mixed Solid Waste--Stored and newly generated materials are treated as required by permits. The mixed waste is converted to a disposal form and is disposed of onsite in permitted near-surface disposal systems. A possible alternative would include retrieval of buried low-level mixed solid waste for treatment along with stored and newly generated materials.

- Low-Level Solid Waste--Material continues to be disposed of in nearsurface trenches, which are closed as landfi]ls. The LLW buried outside the 200 Areas is retrieved and transferred to similar nearsurface trenches in the 200 Areas.

- Nonradioactive Hazardous Solid Waste--Shipment of hazardous waste materials offsite for treatment and disposal continues. 
- Nonradioactive, Nonhazardous Solid Waste--Nonradioactive, nonhazardous solid waste is currently sent to the landfill located in the 600 Area. The central landfill will be full in FY 1996. This category of waste is planned to be shipped offsite.

- Production Reactor Graphite Cores--A decommissioning option that transfers the reactor cores to the 200 Areas as solid waste is assumed to have been selected by the Surplus Production Reactor Decommissioning-Environmental Impact Statement record of decision. Therefore, the solid waste mission area should accommodate disposal of the production reactor cores.

- Alkali Metal Material Storage--A complete 1992 planning basis for alkali metal disposition has not yet been identified. The primary option available for sodium is conversion to a hydroxide for reuse in the future offsite processing activities.

- Offsite Waste--A variety of offsite locations transfer solid waste to the Hanford Site for storage and disposal. Most waste comes from commercia? sources for disposal by U.S. Ecology on the state leased 1 and south of the 200 Area corridor. These materials will continue to be received according to existing agreements and will be disposed of according to waste class, along with the waste currently in the Hanford Site inventory.

Liquid Effluents. The Hanford Site is committed to stop discharging untreated liquid effluents. The 1992 planning basis for liquid effluents focuses on implementing the best avai?able treatment technology that is economically achievable. The 242-A Evaporator/PUREX Plant Process Condensate Treatment Facility (Effluent Treatment Facility) is being constructed to treat and dispose of the liquid effluent stream from the 242-A Evaporator and, should it be required, two PUREX streams. For the other streams in the 200 Areas, best available treatment technology will be implemented at the point of origin. Collection systems are being constructed to transport these clean effluents to a permitted disposal structure.

The liquid effluent treatment facility will generate secondary wastes containing the contaminants emoved by the treatment systems. The liquid effluent mission area will stabilize and package the removed contaminants, and transfer the resulting hazardous and mixed waste to the solid waste mission area for disposal as newly generated waste from cleanup activities.

Actions Needed to Complete the Solid and Liquid Waste Disposal Mission

- Complete retrieval of all buried TRU. Projects planned to meet this need include Enhanced RMW Storage, Solid Waste Retrieval Facility phase 1 and phase 2, and alpha caisson retrieval.

- Build and operate the Waste Receiving and Processing Facility to prepare TRU waste for shipment offsite and RMW disposal onsite. 
- Implement best available technology to treat liquid effluents (e.g., sanitary, Phase I, Phase II, PUREX Plant, 242-A Evaporator/ Crystallizer condensate) before disposal, and identify permitted disposal options for these liquid effluent streams.

\subsubsection{Nuclear Facilities}

Facilities Operations. The 1992 planning basis for irradiated fuel presupposes the results for a record of decision from an environmental impact statement on irradiated fuel disposition. As the 1992 planning basis, all fuel is repackaged in the existing form and stored in interim storage facilities for 10 to 20 years. The likely strategy of disposition is conversion of $N$ Reactor and single-pass reactor fuel to a stable form, which is acceptable for repository disposal. The Fast Flux Test Facility (FFTF) and Shippingport Naval Reactor fuel would be directly packaged for repository disposal. The fuel forms packaged for repository disposal are then placed in a facility for onsite storage until a repository is available.

The 1992 planning basis for special nuclear material that contains high concentrations of plutonium (e.g., oxide, metal) is based on treatment via partitioning flowsheets, with the resultant recovered special nuclear material placed in onsite secured storage. The special nuclear material that contains low concentrations of plutonium, or is in a foriil for which recovery is difficult (e.g., filters, ash, sludge), will be treated via a conversion flowsheet and placed in secured storage. All material then will be available for offsite shipment, after an indeterminate storage period.

The 1992 planning basis for uranium materials uses uranium oxide and metal as the preferred storage forms. The uranium billets are packaged and stored as metal billets, and the clad fuel and uranyl nitrate hexahydrate are converted to uranium oxide. The material is stored for future offsite shipment after an indeterminate storage period.

\section{Actions Needed to Complete the Nuclear Facilities Mission}

- Decontaminate and decommission nuclear facilities within the planning period.

- Upgrade or replace existing facilities for storing irradiated materials.

- Provide a facility to convert $N$ Reactor and single-pass reactor fuel to a stable form that is acceptable for repository disposal.

\subsubsection{Science and Technology} mission.

The following assumptions are made about the science and technology

- Meteorological information will continue to be gathered and compiled in the 200 Areas. 
- The PNL will continue to provide independent environmental surveillance and oversight of area operations.

- Research and development will continue in the area of hazardous waste characterization and remediation, including development of the following:

- Improved sensing and measurement technology

- Novel concepts for in situ or other remediation of wastes using physical, chemical, or biological processes

- Intermediate- and field-scale research to evaluate remediation methods.

- Technologies developed will be applied to waste treatment, storage, and disposal activities in the 200 Areas.

- Technologies developed and demonstrated in the underground storage tank integrated demonstration will be applied to tank wastes in the 200 Areas.

- Other integrated demonstrations and integrated programs will have applications in the 200 Areas.

- Efforts for the Environmental Science and Technology Complex will identify new technology development facilities and pilot plants, which may be located in the 200 Areas.

\subsubsection{Site Support}

The following actions are needed/planned by the Site support mission.

- Add and/or replace office and other support facilities to relieve overcrowding and to vacate old, maintenance-intensive facilities.

- Replace the aging central steam plants with distributed package boilers or a new central steam plant. A central steam plant could be owned and operated by DOE or privately.

- Upgrade the main road to, through, and around the 200 Areas to handle higher traffic volumes and heavy hauling.

- Upgrade, replace, and extend the 200 Areas infrastructure to serve the new cleanup work centers in the 200 Areas (e.g., HWVP, HCWC, Tank Waste Remediation System).

- Replace the aging decontamination laundry facility by contracting for offsite laundry services by a private facility to be located in Richland.

- Decommission the existing decontamination laundry facility. 
DOE/RL-92-29

\subsubsection{Special Initiatives}

The following assumptions are made about the special initiatives mission.

- Special initiatives, such as space programs and isotopes, will be developed outside of the 200 Areas.

- Wastes generated by special initiatives could be processed or stored in the 200 Areas.

\subsection{POPULATION}

The number of employees on the Hanford Site grew significantly in FY 1990 and FY 1991, while the number of employees in the 200 Areas increased only moderately. This was because of an ongoing, severe shortage of office space primarily in the 200 Areas. The overflow of personnel who cannot get offices in the 200 Areas caused significant growth in the downtown Richland area. At the end of FY 1992, there were 5,019 staff members in the 200 Areas. Overall, 3,045 (61 percent) were office and laboratory personnel and 1,974 (39 percent) were bargaining personnel.

The 200 Area population will continue to increase during the next 5 years to support tank farm operations, solid/liquid waste, analytical laboratory, D\&D, and tank waste remediation system activities. These increases will be composed primarily of office and laboratory personnel. Growth will level off in the late 1990's and early 2000's then begin a gradual downward trend as the cleanup mission progresses. Moderate increases in the number of bargaining personnel are expected to occur through FY 1996 and larger increases are expected later in the 1990 's as environmental cleanup activities begin to expand.

Current staffing projections indicate that approximately 6,150 people will be located in the 200 Area by the end of FY 1997. Of this total, approximately 3,960 (64\%) will be office and laboratory personnel and 2,190 (36\%) will be bargaining personnel.

During the mid to late 1990 's, construction personnel will increase significantly with the construction of the HWVP projects, HCWC, Pretreatment Modules, and tank farm projects. These projects along with other facility and infrastructure projects will represent an additional peak population of between 2,000 and 3,000 construction workers during the mid to late 1990's. This projection is based on the assumption that all projects will be funded and completed as currently scheduled. Based on these projections, approximately 8,625 people will be located in the 200 Areas by the end of FY 1997. Table 2-1 presents a breakdown of projected populations in the 200 Area. Appendix B contains projected contractor, RL, and construction worker populations by area. 
Table 2-1. 200 Areas Projected Population (as of September 1992).

\begin{tabular}{|c|c|c|c|c|c|c|c|}
\hline \multirow[t]{2}{*}{ Organization } & \multirow{2}{*}{$\begin{array}{l}\text { Type of } \\
\text { personnel }\end{array}$} & Actual & \multicolumn{5}{|c|}{ Projected } \\
\hline & & 1992 & 1993 & 1994 & 1995 & 1996 & 1997 \\
\hline \multirow{2}{*}{$\begin{array}{l}\text { Hanford } \\
\text { Environmental } \\
\text { Health } \\
\text { Foundation }\end{array}$} & $\begin{array}{l}\text { Office/Lab } \\
\text { Bargaining }\end{array}$ & $\begin{array}{r}4 \\
-- \\
\end{array}$ & $\begin{array}{r}4 \\
-- \\
\end{array}$ & $\begin{array}{r}5 \\
--\end{array}$ & $\begin{array}{r}6 \\
--\end{array}$ & $\begin{array}{r}6 \\
--\end{array}$ & $\begin{array}{r}6 \\
--\end{array}$ \\
\hline & Total & 4 & 4 & 5 & 6 & 6 & 6 \\
\hline \multirow{2}{*}{$\begin{array}{l}\text { Kaiser } \\
\text { Engineers } \\
\text { Hanford }\end{array}$} & $\begin{array}{l}\text { Office/Lab } \\
\text { Bargaining }\end{array}$ & $\begin{array}{l}182 \\
244 \\
\end{array}$ & $\begin{array}{l}216 \\
220 \\
\end{array}$ & $\begin{array}{l}236 \\
225 \\
\end{array}$ & $\begin{array}{l}251 \\
230 \\
\end{array}$ & $\begin{array}{l}261 \\
235 \\
\end{array}$ & $\begin{array}{l}281 \\
240\end{array}$ \\
\hline & Total & 426 & 436 & 461 & 481 & 496 & 521 \\
\hline \multirow{2}{*}{$\begin{array}{l}\text { Pacific } \\
\text { Northwest } \\
\text { Laboratory }\end{array}$} & $\begin{array}{l}\text { Office/Lab } \\
\text { Bargaining }\end{array}$ & $\begin{array}{r}8 \\
--\end{array}$ & $\begin{array}{r}8 \\
--\end{array}$ & $\begin{array}{r}8 \\
--\end{array}$ & $\begin{array}{r}8 \\
--\end{array}$ & $\begin{array}{r}8 \\
--\end{array}$ & $\begin{array}{r}8 \\
--\end{array}$ \\
\hline & Total & 8 & 8 & 8 & 8 & 8 & 8 \\
\hline \multirow{2}{*}{$\begin{array}{l}\text { Stone \& Webster } \\
\text { Engineering } \\
\text { Corporation }\end{array}$} & $\begin{array}{l}\text { Office/Lab } \\
\text { Bargaining }\end{array}$ & $\begin{array}{l}12 \\
-- \\
\end{array}$ & $\begin{array}{l}10 \\
-- \\
\end{array}$ & $\begin{array}{l}10 \\
--\end{array}$ & $\begin{array}{c}10 \\
--\end{array}$ & $\begin{array}{l}10 \\
--\end{array}$ & $\begin{array}{l}10 \\
--\end{array}$ \\
\hline & Total & 12 & 10 & 10 & 10 & 10 & 10 \\
\hline \multirow[t]{2}{*}{$\begin{array}{l}\text { Westinghouse } \\
\text { Hanford Company }\end{array}$} & $\begin{array}{l}\text { Office/Lab } \\
\text { Bargaining }\end{array}$ & $\begin{array}{l}2,824 \\
1,730 \\
\end{array}$ & $\begin{array}{l}3,050 \\
1,765\end{array}$ & $\begin{array}{l}3,260 \\
1,790\end{array}$ & $\begin{array}{l}3,415 \\
1,890 \\
\end{array}$ & $\begin{array}{l}3,520 \\
1,920\end{array}$ & $\begin{array}{l}3,565 \\
1,950 \\
\end{array}$ \\
\hline & Total & 4,554 & 4,815 & 5,050 & 5,305 & 5,440 & 5,965 \\
\hline \multirow{2}{*}{$\begin{array}{l}\text { U.S. Department } \\
\text { of Energy, } \\
\text { Richland Field } \\
\text { Office }\end{array}$} & $\begin{array}{l}\text { Office/Lab } \\
\text { Bargaining }\end{array}$ & $\begin{array}{l}15 \\
-- \\
\end{array}$ & $\begin{array}{l}85 \\
-- \\
\end{array}$ & $\begin{array}{l}85 \\
-- \\
\end{array}$ & $\begin{array}{l}85 \\
-- \\
\end{array}$ & 90 & $\begin{array}{l}90 \\
-- \\
\end{array}$ \\
\hline & Total & 15 & 85 & 85 & 85 & 90 & 90 \\
\hline \multirow{2}{*}{$\begin{array}{l}\text { Total of DOE } \\
\text { and Site } \\
\text { contractors }\end{array}$} & $\begin{array}{l}\text { Office/Lab } \\
\text { Bargaining }\end{array}$ & $\begin{array}{l}3,045 \\
1,974 \\
\end{array}$ & $\begin{array}{l}3,373 \\
1,985 \\
\end{array}$ & $\begin{array}{l}3,604 \\
2,015 \\
\end{array}$ & $\begin{array}{l}3,775 \\
2,120 \\
\end{array}$ & $\begin{array}{l}3,895 \\
2,155 \\
\end{array}$ & $\begin{array}{l}3,960 \\
2,190 \\
\end{array}$ \\
\hline & Total & 5,019 & 5,358 & 5,619 & 5,895 & 6,050 & 6,150 \\
\hline $\begin{array}{l}\text { Construction } \\
\text { workers }\end{array}$ & Total & 145 & 425 & 775 & 1,500 & 2,275 & 2,475 \\
\hline Total* & Total & 5,164 & 5,783 & 6,394 & 7,395 & 8,325 & 8,625 \\
\hline
\end{tabular}

DOE = U.S. Department of Energy.

* See Appendix B for projected populations in each of the 200 East Area, 200 Area Corridor, and 200 West Area. 


\subsection{FACILITIES AND INFRASTRUCTURE}

The analysis of facilities in this section focuses on the demolition of older or inadequate facilities as well as 5-year and long-range projects. Infrastructure is divided into three areas: transportation, utilities, and emergency services. Transportation includes existing and planned road and rail routes. Utilities include water, telecommunications, electrical, steam, and sewer. Emergency services include fire and medical services. Several deficiencies are identified, and recommendations are provided. The Hanford Site Infrastructure Plan (DOE-RL 1990b) provides a comprehensive discussion of the facilities, utilities, systems, and services that support the 200 Areas' activities. This document only provides an overview of the 200 Areas' infrastructure systems.

Many of the 200 Areas' facilities and much of the infrastructure were built in the 1940's and 1950's. Originally, these facilities were expected to be temporary and were constructed accordingly. Consequently, much of the 200 Areas' facilities and infrastructure need major upgrades or replacement.

\subsubsection{Facilities}

There are 651 facilities in the 200 Areas. Of these, 428 are permanent buildings and 223 are mobiles. The gross square footage of the 428 buildings is approximately $2,287,920$. The gross square footage of the 223 mobiles is approximately 30?,215. The total gross square footage for building and mobiles combined is $2,595,135$. Appendix A contains a listing of facilities over 1,000 $\mathrm{ft}^{2}$ and maps showing their location.

2.3.1.1 Dominant Facilities. The dominant structures in the 200 Areas are the PFP and canyon buildings. Those facilities that have floor areas greater than $50,000 \mathrm{ft}^{2}$ are listed below.

Major Buildings in the 200 Areas.

\begin{tabular}{|c|r|l|c|}
\hline Area & $\begin{array}{c}\text { Building } \\
\text { number }\end{array}$ & \multicolumn{1}{|c|}{ Building name } & $\begin{array}{c}\text { Building size } \\
\left(\mathrm{ft}^{2}\right)\end{array}$ \\
\hline 200 West & $234-5 Z$ & Plutonium Finishing Plant & 212,477 \\
\hline 200 East & $202 \mathrm{~A}$ & PUREX Plant Canyon and Service Facility & 188,890 \\
\hline 200 East & $2101 \mathrm{M}$ & Spare Parts Warehouse, Office Building & 169,320 \\
\hline 200 West & $202 S$ & REDOX Canyon and Service Facility & 149,935 \\
\hline 200 West & $221 \mathrm{~T}$ & Process, Canyon, Laboratory and Office & 97,711 \\
\hline 200 East & $2750 \mathrm{E}$ & $\begin{array}{l}\text { Waste Management Surveillance and } \\
\text { Operating Facility }\end{array}$ & 96,000 \\
\hline 200 East & $221 \mathrm{~B}$ & Process Treatment Building, Canyon & 83,500 \\
\hline 200 West & $221 \mathrm{U}$ & U Plant Canyon and Service Building & 83,500 \\
\hline 200 West & $222 S$ & Control Laboratory & 60,167 \\
\hline
\end{tabular}


2.3.1.2 200 Areas Inadequate Facilities. Tables 2-2 and 2-3 1 ist the existing inadequate facilities in the 200 East and 200 West Areas, respectively. The term "inadequate" applies to the substandard structural (e.g., foundation, walls, roof) or technological [e.g., heating, ventilation, and air conditioning (HVAC), electrical, piping] status of the building (DOE/RL-89-01) (DOE-RL 1989). These facilities often require renovation to meet increasingly stringent health and safety codes or to meet simple program needs. For example, the HVAC in these facilities is often characterized by substandard output even with careful operator attention, repetitive maintenance, occasional to constant downtime, and costly operations and maintenance because of the physical condition of the plant and equipment.

Population growth in the 200 Area requires continued occupancy of most of the inadequate facilities despite incompatibilities between buildings and programs. Continued occupancy of these inadequate facilities increases the need to renovate major building systems to meet codes and regulations. Inadequate facilities and systems identified as deficient, relative to contemporary safety codes and standard design criteria, will (1) be modified and upgraded to meet current requirements if cost effective and necessary to maintain required margins, (2) continue to operate if within acceptable risk operating constraints, or (3) be replaced with a facility or system meeting applicable criteria.

Twenty-one percent of the gross square footage of all buildings in the 200 Areas that are not already in the Decontamination and Decommissioning Program are inadequate facilities. The accumulation of inadequate facilities is the result of funding only the highest priority efforts, which are the facilities that have an immediate and direct impact on programmatic goals.

The inadequate facilities list will be updated as ongoing Condition Assessment Survey and Inadequate Facility Assessment and Disposition continues to monitor the 200 Areas' facilities.

2.3.1.3 Decommissioning and Demolition. Of the 651 existing facilities in the 200 Areas, 64 percent of the square footage is over 30-years old with a majority of the facilities constructed in the 1940's and 1950's.

There are 91 inadequate facilities identified for D\&D or demolition in the 200 Areas. The removal of these facilities is contingent on facility and funding availability. The gross square footage of these facilities is 30 percent of the gross square footage of all the 200 Areas facilities combined.

The 22 decontamination and decommissioning projects listed in Table 2-4 (see Figure 2-1 for location) identify 52 structures with a gross square footage of $357,620 \mathrm{ft}^{2}$, which have been planned to be decommissioned from 1986 through 2017 at a cost of over $\$ 410$ million. Four of the structures have already been demolished. 
Table 2-2. 200 East Area Inadequate Facilities List.

\begin{tabular}{|c|c|c|c|c|}
\hline $\begin{array}{l}\text { Building } \\
\text { number }\end{array}$ & Building name & $\begin{array}{c}\text { Year } \\
\text { constructed }\end{array}$ & $\begin{array}{l}\text { Square } \\
\text { footage }\end{array}$ & $\begin{array}{l}\text { Number of } \\
\text { occupants }\end{array}$ \\
\hline 12654 & Changeroom Trailer & 1971 & 112 & \\
\hline 15342 & Office/Craft Lunchroom Trailer & 1977 & 720 & \\
\hline $2101 \mathrm{M}$ & Spare Parts/Office & 1953 & 160,559 & 112 \\
\hline 2228 & office & 1944 & 7,501 & 18 \\
\hline 2701EB & Muin Guard station & 1980 & 50 & \\
\hline 2701ED & Guurd House, West Entrance & 1974 & 50 & \\
\hline 2701EF & Property Protected Area Badgehouse & 1986 & 140 & \\
\hline $2704 \mathrm{C}$ & Office & 1952 & 1,025 & \\
\hline $2707 E$ & Change House & 1944 & 2,553 & 15 \\
\hline 2718 & Service and office Building & 1944 & 30,700 & 114 \\
\hline $2713 E$ & Office & 1944 & 4,127 & 23 \\
\hline $2715 E$ & Paint and oil storage & 1944 & 952 & \\
\hline 2715EA & Point Booth & 1944 & 320 & \\
\hline $2719 E$ & Computer shop & 1944 & 833 & \\
\hline $2722 E$ & office & 1944 & 1,200 & 33 \\
\hline 274E & Lendlord Meintenance Office & 1944 & 3,815 & 24 \\
\hline $273 E$ & Carpenter Shop & 1944 & 5,285 & 15 \\
\hline 27JEA & Storage & 1944 & 36,000 & \\
\hline 284E & Powerhouse & 1944 & 33,815 & 48 \\
\hline $2918 A$ & Air Sempler & 1956 & 49 & \\
\hline MO- 114 & Mobile office at $2418 \mathrm{BY}$ & 1977 & 300 & \\
\hline$M 0-317$ & Mobile office at $2704 \mathrm{C}$ & 1961 & 300 & \\
\hline$n 0-323$ & Mobile Office at $202 A$ & 1975 & 600 & 4 \\
\hline $100-324$ & Chengeroan Trailer ot 284E & 1961 & 325 & \\
\hline no-327 & Changeroam Trailer at $218 E$ & 1961 & 325 & \\
\hline M0-337 & Changeroom Trailer at $2704 \mathrm{C}$ & $196:$ & 300 & \\
\hline $190-666$ & Mobile office at $202 A$ & 1967 & 520 & 5 \\
\hline 10.707 & Mobile office at $202 A$ & 1966 & 520 & 3 \\
\hline 10.997 & Mobile office at Grout & 1975 & 1,440 & \\
\hline \multicolumn{3}{|c|}{200 East Area inadequate facillities total } & 294,996 & 414 \\
\hline \multicolumn{3}{|c|}{ Combined 200 Areas' inadequate facilities total (see Table 2-3) } & 511,923 & 881 \\
\hline
\end{tabular}

NOTE: This list does not include facilities already in the Decontanination and Decommissioning Progran. 
Table 2-3. 200 West Area Inadequate Facilities List.

\begin{tabular}{|c|c|c|c|c|}
\hline $\begin{array}{l}\text { Building } \\
\text { number }\end{array}$ & Building name & $\begin{array}{c}\text { Year } \\
\text { constructed }\end{array}$ & $\begin{array}{c}\text { Square } \\
\text { footage }\end{array}$ & $\begin{array}{l}\text { Number of } \\
\text { occupants }\end{array}$ \\
\hline 2195 & Waste Treatment & 1952 & 1,100 & \\
\hline $222 U$ & Office and Laboratory Building & 1945 & 7,508 & \\
\hline 2312 & Materials Engineering Laboratory & 1944 & 38,451 & 80 \\
\hline 27045 & Offices & 1944 & 8,065 & 43 \\
\hline $2704 \mathrm{H}$ & Office & 1945 & 6,457 & 28 \\
\hline 27042 & office & 1949 & 3,911 & 12 \\
\hline $2707 N$ & Change House & 1944 & 2,616 & 11 \\
\hline 2709 w & Maintenance Storage & 1965 & 1,860 & 28 \\
\hline $2710 \mathrm{~s}$ & Inert Gas Generator & 1952 & 400 & \\
\hline $2713 \mathrm{~W}$ & Maintenance Garage & 1944 & 4,160 & 14 \\
\hline 2713WB & Storage & 1944 & 6,150 & \\
\hline $2715 W$ & Inflamable storage & 1944 & 588 & \\
\hline 27152 & Storage & 1958 & 192 & \\
\hline 2719 WA & First-Aid, Hanford Environmental Health Foundation & 1949 & 2,269 & 6 \\
\hline $271 T$ & Office & 1944 & 30,700 & 80 \\
\hline 2710 & Office/Shop Storage & 1952 & 30,700 & \\
\hline $2720 \mathrm{~W}$ & Patrol Headquarters Office & 1944 & 2,216 & \\
\hline $2722 \mathrm{~W}$ & Storage & 1944 & 1,474 & 1 \\
\hline $2723 W$ & office & 1944 & 4,515 & 40 \\
\hline $2724 \mathrm{H}$ & Laundry & 1950 & 14,657 & 42 \\
\hline $2724 \mathrm{WB}$ & Laundry Storage Facility & 1979 & 1,600 & \\
\hline 27252 & Storage & 1965 & 400 & \\
\hline 27275 & Storage & Unknown & 800 & \\
\hline 2744 & Office & 1945 & 3,815 & 16 \\
\hline $275 \mathrm{H}$ & Landl ord Maintenance Shop and Changeroom & 1944 & 3,792 & 12 \\
\hline $284 \mathrm{H}$ & Powerhouse & 1944 & 27,132 & 14 \\
\hline $292 T$ & FP Release Lab & 1950 & 919 & \\
\hline 190.014 & Mobile office at $234-52$ & 1977 & 924 & 7 \\
\hline MO-015 & Mobile Office at $234-52$ & 1976 & 672 & 2 \\
\hline M0-016 & Mobile Office at $234-52$ & 1976 & 672 & 5 \\
\hline MO-017 & Mobile Office at $234-52$ & 1975 & 672 & 4 \\
\hline MO-319 & Mobile Office & 1961 & 300 & \\
\hline $140-320$ & Female Changeroom at 242-s & 1961 & 300 & \\
\hline MO-326 & Decontamination/Changeroom Facility at 2725 & 1961 & 300 & \\
\hline $40-924$ & Mobile Office at 27045 & 1977 & 1,344 & 11 \\
\hline Mo-936 & Mobile Office at $222 \mathrm{~s}$ & 1977 & 1,584 & 8 \\
\hline M0.939 & Mobile Office at 2342 & 1977 & 672 & 3 \\
\hline$W-19$ & Iron Workers' Shop & Unknown & 1,152 & \\
\hline $\mathrm{N-26}$ & Carpenters' Storage & Unknown & 864 & \\
\hline$W-27$ & Carpenters' Shop & Unknown & 880 & \\
\hline$\times 8$ & Gang Car Storage & 1945 & 144 & \\
\hline \multicolumn{3}{|c|}{200 West Area inadequate facilities total } & 216,927 & 467 \\
\hline \multicolumn{3}{|c|}{ Combined 200 Areas' inadequate facilities total (see Table 2-2) } & 511,923 & 881 \\
\hline
\end{tabular}

NOTE: This list does not include facilities already in the Decontamination and Decomissioning Program. 
Table 2-4. Decommissioning Projects. (sheet 1 of 2)

\begin{tabular}{|c|c|c|c|}
\hline Schedule & Cost & Project & Description \\
\hline $\begin{array}{l}\text { FY } 1986 \\
\text { to } 2000\end{array}$ & $\begin{array}{l}523.7 \\
\text { million }\end{array}$ & $\begin{array}{l}201-C \text { Bullding, } \\
\text { stront ium Semiworks } \\
\text { Decomissioning }\end{array}$ & $\begin{array}{l}\text { Total project costs include demolishing } 201-C, 291-C \text {, } \\
2707-c \text { Buildings and the } 291-\mathrm{C}-1 \text { stack, which have } \\
\text { been completed. Cont inuing demol ition of } 215-\mathrm{C} \text {, } \\
271-\mathrm{C} \text { Buildings; } 291-\mathrm{C}-2 \text { stack; } 241-\mathrm{Cx} ; 70,71 \text {, and } \\
72 \text { tanks and vaults. }\end{array}$ \\
\hline $\begin{array}{l}\text { Fy } 1988 \\
\text { to } 2002\end{array}$ & $\begin{array}{l}\$ 14.8 \\
\text { milition }\end{array}$ & $\begin{array}{l}224-B \text { Building, } \\
\text { Plutonium } \\
\text { Concentration } \\
\text { Facility } \\
\text { Decomissioning }\end{array}$ & $\begin{array}{l}\text { This project is to continue decomissioning } \\
224-8 \text { Building. }\end{array}$ \\
\hline $\begin{array}{ll}\text { Fy } & 1990 \\
\text { to } & 1999\end{array}$ & $\begin{array}{l}\$ 16.9 \\
\text { mililion }\end{array}$ & $\begin{array}{l}233-5 \text { Building, } \\
\text { Plutonium } \\
\text { Concentration } \\
\text { Facllity } \\
\text { Decomissioning }\end{array}$ & $\begin{array}{l}\text { Total project costs include continued decommissioning } \\
\text { of the 233-5 and 233-SA Bulldings; } 296-5-7 \text { stack; and } \\
\text { the procurement of a compactor. }\end{array}$ \\
\hline $\begin{array}{ll}\text { Fy } & 1992 \\
\text { to } & 1994\end{array}$ & $\begin{array}{l}\$ 2.3 \\
\text { million }\end{array}$ & $\begin{array}{l}232-2 \text { Building, Waste } \\
\text { Incinerator } \\
\text { Decomissioning }\end{array}$ & This project is to decomisston the $232-2$ Building. \\
\hline $\begin{array}{ll}\text { FY } & 1998 \\
\text { to } & 1998\end{array}$ & $\$ 255,000$ & $\begin{array}{l}276-C \text { Bullding, } \\
\text { Solvent Handling } \\
\text { Facillity } \\
\text { Decomissioning }\end{array}$ & This project is to desomission the $276 . \mathrm{C}$ Building. \\
\hline $\begin{array}{l}\text { Fy } 1999 \\
\text { to } 1999\end{array}$ & $\$ 1$ million & $\begin{array}{l}276-\text { s Building, } \\
\text { Solvent Handling } \\
\text { Facillity } \\
\text { Decormissioning }\end{array}$ & $\begin{array}{l}\text { Total project costs include decomilssioning of } \\
276-5 \text { Building, } 296-5-12 \text { stacks, i276-s-141 and } \\
276-5-142 \text { tanks and vault. }\end{array}$ \\
\hline $\begin{array}{l}\text { FY } 2000 \\
\text { to } 2000\end{array}$ & $\begin{array}{l}\text { s2.3 } \\
\text { milition }\end{array}$ & $\begin{array}{l}222-1 \text { building, } \\
\text { Office and storage } \\
\text { Facllity } \\
\text { Decommissioning }\end{array}$ & This project is to decommission the 222-T Building. \\
\hline $\begin{array}{l}\text { Fr } 2001 \\
\text { to } 2001\end{array}$ & $\begin{array}{l}\$ 2.3 \\
\text { milition }\end{array}$ & $\begin{array}{l}222-U \text { bullding, } \\
\text { office and storage } \\
\text { Facillity } \\
\text { Decomissioning }\end{array}$ & This project is to decomission the $222-U$ Building. \\
\hline $\begin{array}{l}\text { FY } 2001 \\
\text { to } 2001\end{array}$ & $\begin{array}{l}\text { \$1.3 } \\
\text { milition }\end{array}$ & $\begin{array}{l}\text { "212-N Building, } \\
\text { Storage Facillity } \\
\text { Decomissioning }\end{array}$ & This project is to decomission the $212-N$ Building. \\
\hline $\begin{array}{l}\text { FY } 2002 \\
\text { to } 2002\end{array}$ & $\begin{array}{l}\$ 1.3 \\
\text { milition }\end{array}$ & $\begin{array}{l}\text { "212-p Building, Stors } \\
\text { ge Focillty } \\
\text { Decomissioning }\end{array}$ & This project is to decomission the $212-\mathrm{p}$ Building. \\
\hline $\begin{array}{l}\text { FY } 2002 \\
\text { to } 2002\end{array}$ & $\$ 931,000$ & $\begin{array}{l}241-A-431 \text { Building, } \\
\text { Tank Farm Ventillation } \\
\text { Facility }\end{array}$ & $\begin{array}{l}\text { This project is to decommission the } \\
241-A-431 \text { Building. }\end{array}$ \\
\hline $\begin{array}{l}\text { FY } 2002 \\
\text { to } 2002\end{array}$ & $\begin{array}{l}\text { s1.7 } \\
\text { milition }\end{array}$ & $\begin{array}{l}242-B \text { and } 242-B L \\
\text { Laboratories } \\
\text { Decomissioning }\end{array}$ & $\begin{array}{l}\text { This project is to decomission the } 242-8 \text { and } \\
242-8 L \text { Buildings. }\end{array}$ \\
\hline $\begin{array}{l}\text { FY } 2003 \\
\text { to } 2003\end{array}$ & $\$ 732,000$ & $\begin{array}{l}241-C-801 \text { Building, } \\
\text { Cesium Losdout } \\
\text { Facillty } \\
\text { Decomissioning }\end{array}$ & $\begin{array}{l}\text { This profect is to decommission the } 241-C-801 \\
\text { Building. }\end{array}$ \\
\hline $\begin{array}{l}\text { FY } 2003 \\
\text { to } 2003\end{array}$ & $\$ 481,000$ & $\begin{array}{l}205-A \text { Building, } \\
\text { Silice Gel facility } \\
\text { Decomissioning }\end{array}$ & This project is to decommission the 205-A Building. \\
\hline $\begin{array}{l}\text { Fy } 2003 \\
\text { to } 2003\end{array}$ & $\begin{array}{l}\$ 2.6 \\
\text { milition }\end{array}$ & $\begin{array}{l}216-2-9 \text { Mining } \\
\text { Facility } \\
\text { Decomissioning }\end{array}$ & $\begin{array}{l}\text { This project is to decomission the } 216-2-9 \text { Mining } \\
\text { Facility. }\end{array}$ \\
\hline $\begin{array}{l}\text { FY } 2003 \\
\text { to } 2003\end{array}$ & $\begin{array}{l}\$ 1.3 \\
\text { milition }\end{array}$ & $\begin{array}{l}212-R \text { building, } \\
\text { Storage Facillity } \\
\text { Decomiseioning }\end{array}$ & This project is to decomission the $212-R$ Building. \\
\hline
\end{tabular}


Table 2-4. Decommissioning Projects. (sheet 2 of 2)

\begin{tabular}{|c|c|c|c|}
\hline Schedule & $\operatorname{Cos} t$ & Project & Description \\
\hline $\begin{array}{l}\text { FY } 2004 \\
\text { to } 2015\end{array}$ & $\begin{array}{l}\$ 156.5 \\
\text { Million }\end{array}$ & $\begin{array}{l}\text { 2221-U Building, } \\
\text { (U Plant) Canyon } \\
\text { Decommissioning }\end{array}$ & $\begin{array}{l}\text { Total project costs include decommissioning the } \\
221-U, 276-U, 271-U, 291-U \text { Builidings, and } 296-U-1 \text {, } \\
296-U-6 \text {, and } 296-U-10 \text { stacks. }\end{array}$ \\
\hline $\begin{array}{l}\text { FY } 2004 \\
\text { to } 2017\end{array}$ & $\begin{array}{l}\$ 174.8 \\
\text { million }\end{array}$ & $\begin{array}{l}\text { 202-s (REDOX) Canyon } \\
\text { Decomissioning }\end{array}$ & $\begin{array}{l}\text { Total project costs include decomissioning the } \\
202-5,291-5,292-5,293-5,2711-5,2718-5 \text { Buildings, } \\
\text { and } 296-5-1,296-5-2,296-5-4, \text { and } 296-5-6 \text { stacks. }\end{array}$ \\
\hline $\begin{array}{l}\text { FY } 2005 \\
\text { to } 2005\end{array}$ & $\begin{array}{l}\text { so.4 } \\
\text { milition }\end{array}$ & $\begin{array}{l}\text { 270-E Neutral- } \\
\text { ization Tank } \\
\text { Decomnissioning }\end{array}$ & $\begin{array}{l}\text { This project is to decommission the } \\
270-E \text { neutralization tank. }\end{array}$ \\
\hline $\begin{array}{l}\text { Fy } 2005 \\
\text { to } 2005\end{array}$ & $\begin{array}{l}\$ 1.6 \\
\text { milition }\end{array}$ & $\begin{array}{l}241-5 x-401 \text { Bullding, } \\
\text { Condenser Loodout } \\
\text { Facillity } \\
\text { Decommissioning }\end{array}$ & $\begin{array}{l}\text { This project is to decomission the } \\
241-\text { sx-401 Building. }\end{array}$ \\
\hline $\begin{array}{l}\text { Fy } 2005 \\
\text { to } 2005\end{array}$ & $\begin{array}{l}\$ 1.6 \\
\text { milition }\end{array}$ & $\begin{array}{l}241-5 x-402 \text { Building, } \\
\text { Condenser Loadout } \\
\text { Facillity } \\
\text { Decommissioning }\end{array}$ & $\begin{array}{l}\text { This project is to decommission the } \\
241-5 x-402 \text { suilding. }\end{array}$ \\
\hline $\begin{array}{l}\text { FY } 2006 \\
\text { to } 2006\end{array}$ & $\$ 140,000$ & $\begin{array}{l}\text { 2904-SA Building, } \\
\text { Sampler Facility } \\
\text { Decomissioning }\end{array}$ & This project is to decomission the 2904-SA Building. \\
\hline
\end{tabular}

"Identifies facilities that may meet criteria for nomination for inclusion on the National Register of Historic Places. These facilities should be historically preserved through photography or some other means so that decomissioning can cont inue.

The 43 facilities planned to be decommissioned, in Table 2-5, have a gross square footage of $409,805 \mathrm{ft}^{2}$ and are planned to be transferred to the Decontamination and Decommissioning Program in the fiscal year indicated. Once the factlity has been transferred to the Decontamination and Decommissioning riogram, the facility will be shut down and put under maintenance and surveillance until demolition funding is available.

Some of the facilities in Table 2-5 have had a rough-order-of-magnitude (ROM) cost estimate done for preliminary budget analysis. These ROM cost estimates are determined by multiplying the square footage to be decontaminated and the cubic yards of rubble produced, by a unit cost associated with the specific material it was constructed with, and for the fill and grade of the area. The ROM cost estimates (developed in FY 1990 through FY 1992) do not include any contingencies or allowances for undiscovered conditions, economic inflation, increasingly stringent codes and regulations, or any other additional factors.

These planned and projected decontamination and decommissioning projects account for only 46 percent of the 200 Areas' facility square footage that is over 30-years old. Ongoing condition and assessment survey and inadequate facility assessment and disposition activities will continue to monitor the remaining 54 percent. It is expected that additional facilities will be added to the decontamination and decommissioning list in the near future. 
Figure 2-1. 200 Area Decommissioning Projects.

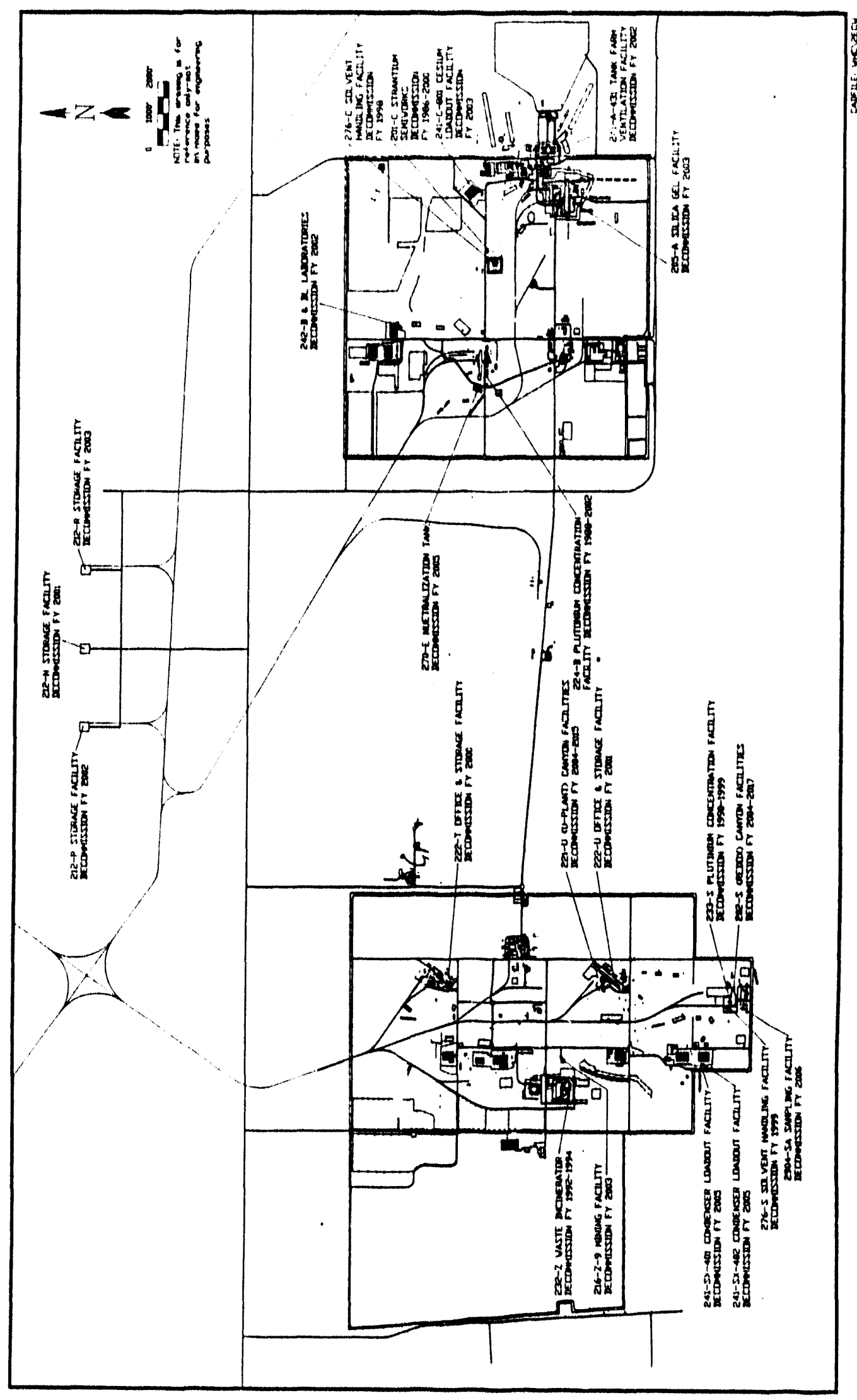


Table 2-5. 200 Areas' Facilities Planned to be Transferred to Decontamination and Decommissioning within the

Next 10 Years. (sheet 1 of 2)

\begin{tabular}{|c|c|c|c|}
\hline schedule & $\begin{array}{c}\text { Bullding } \\
\text { number }\end{array}$ & Building name & $\cos t^{\circ}$ \\
\hline FY 1993 & $\begin{array}{r}W-19 \\
2709-W \\
2720-W \\
2718-E \\
209-E\end{array}$ & $\begin{array}{l}\text { Old Fabrication Shop } \\
\text { office } \\
\text { offlice } \\
\text { Critical Mase Fiselle storage } \\
\text { Critical Mass Laboratory }\end{array}$ & $\begin{array}{r}\$ 35,000 \\
\$ 67,000 \\
\$ 62,000 \\
N / A \\
N / A\end{array}$ \\
\hline FY 1994 & $\begin{array}{r}2707-E \\
2707-H \\
2719-H A \\
2701-2 \\
242-T C \\
242-T B\end{array}$ & $\begin{array}{l}\text { Changeroom } \\
\text { Chengeroom } \\
\text { Medical station } \\
\text { Plutonium Finishing Plant Badgehouse } \\
\text { Metal/Instrument } \\
\text { Metal/Venthouse }\end{array}$ & $\begin{array}{r}\$ 82,000 \\
\$ 73,000 \\
\$ 87,000 \\
N / A \\
N / A \\
N / A\end{array}$ \\
\hline FY 1995 & $\begin{array}{r}2713-E \\
2715-E \\
2715-E A \\
2719-E \\
2722-E \\
274-E \\
222-B\end{array}$ & $\begin{array}{l}\text { Offlce } \\
\text { Paint and oll storage } \\
\text { Paint Booth } \\
\text { Office } \\
\text { offlice } \\
\text { office } \\
\text { office }\end{array}$ & $\begin{array}{r}\$ 97,000 \\
\$ 55,000 \\
N / A \\
\$ 53,000 \\
N / A \\
\$ 91,000 \\
\$ 161,000\end{array}$ \\
\hline FY 1996 & $\begin{array}{r}274-W \\
2704-H \\
2704-C \\
2715-H \\
2722-W\end{array}$ & $\begin{array}{l}\text { Office } \\
\text { office } \\
\text { offlice } \\
\text { Inflemmable storage } \\
\text { storage }\end{array}$ & $\begin{array}{r}\$ 98,000 \\
\$ 8,900 \\
\$ 52,000 \\
\$ 26,000 \\
\$ 51,000\end{array}$ \\
\hline FY 1997 & \begin{tabular}{r|}
$275-E A$ \\
$2723-W$ \\
$X-8$ \\
$242-T$
\end{tabular} & $\begin{array}{l}\text { Werehouse } \\
\text { Office } \\
\text { Gang Car Storage (200W) } \\
\text { Metal, Concrete/Waste }\end{array}$ & $\begin{array}{r}N / A \\
\$ 103,000 \\
\$ 9,000 \\
N / A\end{array}$ \\
\hline FY 1998 & $\begin{array}{l}W-26 \\
W-27\end{array}$ & $\begin{array}{l}\text { Carpentar's Shop } \\
\text { Carpenter's storage }\end{array}$ & $\begin{array}{r}\$ 35,000 \\
\mathrm{~N} / \mathrm{A}\end{array}$ \\
\hline FY 1999 & $275-4$ & Heavy Equipment Shop & 398,000 \\
\hline
\end{tabular}


Table 2-5. 200 Areas' Facilities Planned to be Transferred to Decontamination and Decommissioning within the Next 10 Years. (sheet 2 of 2 )

\begin{tabular}{|c|c|c|c|}
\hline schodule & $\begin{array}{l}\text { Bullding } \\
\text { number }\end{array}$ & Building name & $\cos t$ \\
\hline FY 2001 & $\begin{array}{r}2713-W \\
284-E \\
284-W \\
231-2^{b} \\
2713-W B \\
2724-W \\
292-T \\
275-E \\
2704-2\end{array}$ & $\begin{array}{l}\text { Vehicle Service } \\
\text { Powerhuuse } \\
\text { Powerhouse } \\
\text { Materials Engineering Laboratory } \\
\text { Mointenance Facility } \\
\text { Laundry } \\
\text { FP Release Laboratory } \\
\text { Carpenter's Shop } \\
\text { Office Regulated Equipment }\end{array}$ & $\begin{array}{r}\text { N/A } \\
\$ 1,314,000 \\
\$ 1,306,000 \\
\$ 16,572,000 \\
\$ 199,000 \\
\$ 326,000 \\
\$ 549,000 \\
N / A \\
\$ 110,000\end{array}$ \\
\hline FY 2002 & $\begin{array}{l}2101-M \\
2704-S\end{array}$ & $\begin{array}{l}\text { Spere Porte and Laboratory } \\
\text { office }\end{array}$ & $\begin{array}{r}\$ 2,729,000 \\
\$ 164,000\end{array}$ \\
\hline fY Unknown & $277 \cdot 1$ & Blow Down Building & $N / A$ \\
\hline
\end{tabular}

OFy is the projected year the facillty will be transferred to the Decontamination and Decomissioning Progrem and the costs are rough-order-of-magnitude est imates for degommisaioning the facility.

Facility way met criterie for nomination into the Mationd Reaister of Historic Places. These facllities should be historically preserved through photography or some other mans so that planning for decomissioning can continue. PP = Fission product.

$N / A=$ Not appl leable.

\subsubsection{Line Item Projects}

This section contains a list (Table 2-6) of the line item projects that construct new facilities or otherwise significantly affect 1 and use and infrastructure development. Their proposed locations are shown in Figures 2-2, 2-3, and 2-4. Many more projects (not identified here) are planned consisting of rehabilitation and renovation work, which is being driven by the Site's priority for complying with environmental, safety, and health standards and all applicable laws, regulations, and orders.

The projects listed in Table 2-6 have varying degrees of probability and programmatic clarity. Therefore, this presentation is only for envisioning the potential long-range development in the 200 Areas.

\subsubsection{Infrastructure}

The Facilities Upgrade (Restoration) Program of the early 1980's improved many important systems. The systems that received improvements remain in good condition today, but the systems that did not receive improvements can be rated only as fair to poor. Current funding is inadequate for maintenance and upgrades. Further, with the resurgence of growth in the 200 Areas, the systems will soon be operating beyond existing capacity. Emergency services will also be required to be upgraded in the near future to provide reliable service for this increase in growth. 
Table 2-6. 200 Areas Construction Projects

(More than \$1.2 Million). (sheet 1 of 8 )

\begin{tabular}{|c|c|c|c|c|}
\hline Area & $\begin{array}{l}\text { Fiscal } \\
\text { year } \\
\text { budget }\end{array}$ & $\begin{array}{l}\text { Project } \\
\text { number }\end{array}$ & Project title & Project description \\
\hline \multicolumn{5}{|c|}{ Funded Projects } \\
\hline \multicolumn{5}{|c|}{ Nuclear Facilities } \\
\hline 200 West & 1986 & $c-038$ & PFP Changeroom Addition & $\begin{array}{l}\text { This project provides a } 5,000 \mathrm{ft}^{2} \text { of changeroom } \\
\text { addition with a centralized security access } \\
\text { portal, clean and soiled laundry storage, and a } \\
\text { corridor for women to reach the security portal } \\
\text { from the } 234-52 \text { women's changeroom. }\end{array}$ \\
\hline 200 West & 1989 & $8-610$ & $\begin{array}{l}\text { Plutonium Reclamation } \\
\text { Facility Process } \\
\text { Instrumentation Upgrade }\end{array}$ & $\begin{array}{l}\text { This project will install a distributed process } \\
\text { monitoring and control system. The system will } \\
\text { monitor and control all instruments and equipment } \\
\text { presently connected to the panels in the existing } \\
\text { Plutonium Reclamation Facility control room, plus } \\
\text { adequate spare capacity for future expansion. }\end{array}$ \\
\hline 200 West & 1990 & $B-631$ & $\begin{array}{l}\text { PFP Fire Safety and Loss } \\
\text { Limitations }\end{array}$ & $\begin{array}{l}\text { This project will install an automatic sprinkler } \\
\text { system in the west half of the duct limitation } \\
\text { level, modify or construct new personnel } \\
\text { emergency exit routes from specific rooms and } \\
\text { ereas, upgrade the plant fire alarm system, and } \\
\text { provide fire area separations. }\end{array}$ \\
\hline \multicolumn{5}{|c|}{ site support } \\
\hline 200 East & 1987 & $8-483$ & $\begin{array}{l}\text { Steam System } \\
\text { Rehabilitation Phase I, } \\
200 \text { Area }\end{array}$ & $\begin{array}{l}\text { This project will replace refractory (tubing and } \\
\text { bricks) in } 284 \text { east boilers. }\end{array}$ \\
\hline 200 West & 1990 & $W-001$ & $\begin{array}{l}\text { 222-s Laboratory } \\
\text { Vent il lation and Electrical } \\
\text { system Upgrades }\end{array}$ & $\begin{array}{l}\text { This project will upgrade the existing HVAC } \\
\text { system in the } 222-\mathrm{s} \text { Laboratory, ond upgrade the } \\
\text { electrical system to accomodate the HVAC system } \\
\text { and other facility electrical needs. }\end{array}$ \\
\hline 200 East & 1990 & $8-604$ & $\begin{array}{l}\text { Water System Upgrades- } \\
\text { Reservoir }\end{array}$ & $\begin{array}{l}\text { This project will upgrade the present fire } \\
\text { protection water supply system for the } 200 \text { East } \\
\text { and } 200 \text { West Areas to provide adequate isolated } \\
\text { water storage. ihe project will also provide the } \\
\text { necessary ossociatid piping, equipment, controls, } \\
\text { and beckup power to deliver the water to the } \\
\text { existing distribution system and to interface } \\
\text { with the existing water system controls. Two new } \\
\text { fire protection reservoirs, new emergency fire } \\
\text { protection pumps, and intercomecting piping will } \\
\text { be installed to upgrade the capacity of the } \\
\text { current water storage and supply systems. }\end{array}$ \\
\hline 200 East & 1990 & B-690 & $\begin{array}{l}\text { Steam System } \\
\text { Safety/Productivity } \\
\text { Upgrade }\end{array}$ & $\begin{array}{l}\text { This project will upgrade and/or replace } \\
\text { electrical service, circuits, and components in } \\
\text { the } 282,283 \text {, and } 284 \text { east and west areas } \\
\text { buildings. Also, it will provide upgrades in the } \\
\text { same buildings to comply with current life safety } \\
\text { codes and standards. }\end{array}$ \\
\hline 200 & 1990 & $W-011 H$ & $\begin{array}{l}\text { Waste Sampling and } \\
\text { Characterization facility } \\
\text { (HEC) }\end{array}$ & $\begin{array}{l}\text { This project will provide facility for use in } \\
\text { analyzing low-lovel and nonradioactive samples } \\
\text { from various envirommental and operating programs } \\
\text { on the Hanford site. }\end{array}$ \\
\hline
\end{tabular}


Table 2-6. 200 Areas Construction Projects

(More than $\$ 1.2$ Million). (sheet 2 of 8 )

\begin{tabular}{|c|c|c|c|c|}
\hline Area & $\begin{array}{l}\text { Fiscal } \\
\text { year } \\
\text { budget }\end{array}$ & $\begin{array}{l}\text { Project } \\
\text { number }\end{array}$ & Project title & Project description \\
\hline 200 East & 1991 & $H=041 H$ & $\begin{array}{l}\text { Environmental Hot Cell } \\
\text { Expansion (HEC) }\end{array}$ & $\begin{array}{l}\text { This project provides a new hot cell addition to } \\
\text { the existing } 222-5 \text { Laboratory in the } 200 \text { West } \\
\text { Area. The hot cell consists of seven } \\
\text { compartments and is housed in a } 40,000 \mathrm{ft}^{2} \\
\text { structurally independent building addition. }\end{array}$ \\
\hline 200 East & 1992 & $L-017$ & $\begin{array}{l}\text { Steam Plant Rehabilitation } \\
\text { Phase II }\end{array}$ & $\begin{array}{l}\text { This project will provide for refurbishment of } \\
\text { two coal-fired boilers in the } 284 \text { E Powerhouse } \\
\text { including the ancillery equipment supporting } \\
\text { these boilers. A third coal-fired boiler in the } \\
284 \text {. Powerhouse will also be refurbished with the } \\
\text { exception of the refractory work and tube } \\
\text { replacement. One stand-alone package boiler unit } \\
\text { will be installed near the } 284 \mathrm{~W} \text { Powerhouse, } \\
\text { including ancillary services, to support main- } \\
\text { tenance outages of the inter-ares steem tie line. }\end{array}$ \\
\hline 200 East & 1992 & $L-044$ & $\begin{array}{l}\text { Hanford Infrastructure } \\
\text { Underground Storage Tanks }\end{array}$ & $\begin{array}{l}\text { This project replaces, removes, or upgrades } \\
33 \text { underground storage tanks and associated } \\
\text { piping and equipment. }\end{array}$ \\
\hline \multicolumn{5}{|c|}{ Solid and Liquid Waste } \\
\hline 200 West & 1986 & $c-181$ & 2706-T Facility Upgrades & $\begin{array}{l}\text { This phase I subproject will bring the } 2706-T \\
\text { Facility in compliance with safety and } \\
\text { operational requirements associated with the } \\
\text { operation of a low-level decontamination } \\
\text { facility. }\end{array}$ \\
\hline 200 East & 1987 & $B-455$ & $\begin{array}{c}\text { WESF } K-3 \text { filter System } \\
\text { Uparade } \\
\therefore\end{array}$ & $\begin{array}{l}\text { This project provides new HEPA filter assemblies } \\
\text { for the existing WESF K-3 exhaust system, which } \\
\text { incorporates features to increase system } \\
\text { reliability and environmental safety. }\end{array}$ \\
\hline 200 West & 1988 & $\omega-025$ & $\begin{array}{l}\text { RMW Disposal Facility/ } \\
\text { Mon-Dragoff }\end{array}$ & $\begin{array}{l}\text { This project will provide a RCRA RMU Land } \\
\text { Disposal Facility that will include double } \\
\text { geosynthetic liner and leachate collection } \\
\text { system. The facility will accormodate disposel } \\
\text { of low-level sol id wastes from both onsite and } \\
\text { offsite sources that meet regulatory treatment } \\
\text { standards. }\end{array}$ \\
\hline 200 West & 1989 & $H=016 H$ & RMH Storage Facility (HEC) & $\begin{array}{l}\text { This project provides interim storage facilities } \\
\text { for radioactive mixed waste, ganerated onsite and } \\
\text { offsite, until completion of the WRAP facillity. }\end{array}$ \\
\hline 200 East & 1989 & $H-017 H$ & $\begin{array}{l}\text { Groundwater Monitoring } \\
\text { Well Systems (HEC) }\end{array}$ & $\begin{array}{l}\text { This project provides groundwster monitoring } \\
\text { wells to be constructed between Fy } 1989 \text { and } \\
\text { Fy } 1993 \text {. Based on current compl iance } \\
\text { requirements, an estimated } 165 \text { wells at an } \\
\text { average depth of approximately } 92.44 \text { in }(300 \mathrm{ft}) \\
\text { will be installed. }\end{array}$ \\
\hline 200 & 1989 & $\mathrm{~W}-\mathrm{O2OH}$ & $\begin{array}{l}\text { Waste Management } \\
\text { Facilities Cathodic } \\
\text { Protection (HEC) }\end{array}$ & $\begin{array}{l}\text { This project provides upgrades of cathodic } \\
\text { protection systems to prevent galvanic corrosion } \\
\text { of underground waste transfer lines and } \\
\text { associated equipment in the } 200 \text { Areas. }\end{array}$ \\
\hline 200 East & 1990 & $\mathrm{~W}-\mathrm{O} 010 \mathrm{H}$ & $\begin{array}{l}\text { B Plant Environmental } \\
\text { Compl i ance Upgrades (HEC) }\end{array}$ & $\begin{array}{l}\text { This project will provide engireered barriers to } \\
\text { prevent or mitigate any releases of chemical or } \\
\text { radiological hazardous materials from two B Plant } \\
\text { subsystems: (1) chemical storage system, and } \\
\text { (2) scale tank system. }\end{array}$ \\
\hline 200 West & 1990 & C-031H & $\begin{array}{l}\text { PFP Liquid Effluent } \\
\text { Treatment Facilities (HEC) }\end{array}$ & $\begin{array}{l}\text { This project will upgrade the } 141-2 \text { building and } \\
\text { associated yard piping by replacing four waste } \\
\text { storage treatment tanks, including related pipe, } \\
\text { instrumentation, and tank basin areas to meet } \\
\text { environmental requirements. }\end{array}$ \\
\hline
\end{tabular}


Table 2-6. 200 Areas Construction Projects

(More than $\$ 1.2$ Million). (sheet 3 of 8 )

\begin{tabular}{|c|c|c|c|c|}
\hline Area & $\begin{array}{l}\text { Fiscal } \\
\text { year } \\
\text { budget }\end{array}$ & $\begin{array}{l}\text { Project } \\
\text { number }\end{array}$ & Project title & Project description \\
\hline 200 West & 1990 & B-680H & $\begin{array}{l}\text { PFP Liquid Low-Level Waste } \\
\text { System Modification (HEC) }\end{array}$ & $\begin{array}{l}\text { This project provides two systems for controlling } \\
\text { contaminants in the PFP wastewater discharge to } \\
\text { the } 2-20 \mathrm{Crib} \text {. The project installs a closed } \\
\text { loop cool ing system to reduce the major } \\
\text { radionuclide source potential, and reduce the } \\
\text { volume of wastewater requiring waste treatment } \\
\text { processing. The project then installs a } \\
\text { wastewater treatment facility for controlling the } \\
\text { remaining contaminants that will be discharged to } \\
\text { the } 2-20 \text { Crib. }\end{array}$ \\
\hline 200 West & 1990 & $B-634$ & $\begin{array}{l}\text { PFP Nitrate Handling } \\
\text { System Support }\end{array}$ & $\begin{array}{l}\text { This project will provide soliution storage and } \\
\text { transfer capability to support the PFP operation } \\
\text { of Remote Mechanical "C" line and Plutonium } \\
\text { Reclamation Facility. }\end{array}$ \\
\hline 200 East & 1990 & $W-105$ & $\begin{array}{l}\text { 242-A Evaporation Interim } \\
\text { Retention Basins }\end{array}$ & $\begin{array}{l}\text { This project provides interim storage capability } \\
\text { for process condensate from the } 242-A \text { Evaporator/ } \\
\text { Crystallizer. The project consists of } \\
\text { approximately } 6,000 \mathrm{ft} \text { of } 3-\text { in. carrier piping } \\
\text { with a } 6-\text { in. encasement. The piping supplies } \\
\text { three } 6.5-\mathrm{Mgal} \text { surface impoundments north of the } \\
242-A \text { Evaporator/Crystallizer. }\end{array}$ \\
\hline 200 West & 1991 & $H-026$ & WRAP Facility Module 1 & $\begin{array}{l}\text { This project will construct a } 52,000 \mathrm{ft}^{2} \text { pre- } \\
\text { engireered metal building facility. The facility } \\
\text { provides certification and characterization } \\
\text { capabilities for newly generated and retrieved } \\
\text { solid wastes. }\end{array}$ \\
\hline 200 East & 1991 & $\mathrm{C}-018 \mathrm{H}$ & $\begin{array}{l}\text { 242-A Evaporator/PUREX } \\
\text { Plant Condensate Treatment } \\
\text { Facility }\end{array}$ & $\begin{array}{l}\text { This project provides a liquid effluent treatment } \\
\text { facility for } 242-A \text { Evaporator process condensate, } \\
\text { plus two PUREX Plant process condensate waste } \\
\text { streams. The facility will start operation in } \\
\text { June } 1994 \text {. Initially, the facility will process } \\
13 \text { Mgal of } 242-A \text { Evaporator process condensate } \\
\text { stored in the Liquid Effluent Retention Facillity } \\
\text { basins. Thereafter, the facility will provide } \\
\text { primary effluent treatment for the three streams } \\
\text { identified above. }\end{array}$ \\
\hline 200 & 1992 & $\mathrm{~W}-049 \mathrm{H}$ & $\begin{array}{l}200 \text { Area Treated Effluent } \\
\text { Disposal Facility }\end{array}$ & $\begin{array}{l}\text { This project will construct an effluent gathering } \\
\text { system to verify discharge criteria, and provide } \\
\text { diversion to the state approved disl, sal site. }\end{array}$ \\
\hline \multicolumn{5}{|c|}{ Tank Waste Remediation System } \\
\hline 200 East & 1987 & B-534 & $\begin{array}{l}242-A \\
\text { Evaporator/Crystallizer } \\
\text { Upgrades }\end{array}$ & $\begin{array}{l}\text { This project provides upgrades to the } 242-A \\
\text { Evaporator/Crystallizer Facility including the } \\
\text { primary condenser, electrical, pumps, and vessel } \\
\text { vent and process control system. }\end{array}$ \\
\hline 200 East & 1988 & B-595 & HWVP & $\begin{array}{l}\text { This project will convert the high-level fraction } \\
\text { of the radioactive waste stored in the SSTs and } \\
\text { DSTs located on the Hanford Site into } \\
\text { borosilicate glass. }\end{array}$ \\
\hline 200 East & 1988 & $B-714$ & $\begin{array}{l}\text { Grout Disposal Vaults 102- } \\
105\end{array}$ & $\begin{array}{l}\text { This project constructs four grout disposal } \\
\text { vaul ts. }\end{array}$ \\
\hline 200 East & 1989 & $H=007 \mathrm{H}$ & $\begin{array}{l}\text { B Plant Process Condensate } \\
\text { Treatment Facility }\end{array}$ & $\begin{array}{l}\text { This project will provide condensate effluent } \\
\text { upgrades to B Plant. This project is on hold and } \\
\text { is presently being rescoped. }\end{array}$ \\
\hline 200 East & 1989 & $W-030$ & $\begin{array}{l}\text { Tank Farm Ventilation } \\
\text { Upgrades }\end{array}$ & $\begin{array}{l}\text { This project will upgrade the primary ventilation } \\
\text { system to } 241-A Y \text { and } 241-A Z \text { Tank Farms. }\end{array}$ \\
\hline
\end{tabular}


Table 2-6. 200 Areas Construction Projects

(More than $\$ 1.2$ Million). (sheet 4 of 8 )

\begin{tabular}{|c|c|c|c|c|}
\hline Area & $\begin{array}{l}\text { Fiscal } \\
\text { year } \\
\text { budget }\end{array}$ & $\begin{array}{l}\text { Project } \\
\text { number }\end{array}$ & Project title & Project description \\
\hline 200 East & 1990 & $W-028$ & Aging Waste Transfer Lines & $\begin{array}{l}\text { This project provides for the replacement of } \\
\text { thin-walls, concrete-encased piping with double- } \\
\text { encased piping. Two pipelines will be installed } \\
\text { between the } 241 \text {-AY and } 241-A Z \text { Tank Farms and } \\
\text { B Plant. A diversion box to the south of B Plant } \\
\text { provides for HWVP connection to these lines and } \\
\text { the OST system. The waste transfer lines will be } \\
\text { used for pretreatment and vitrification. }\end{array}$ \\
\hline 200 East & 1990 & $W-125$ & $\begin{array}{l}\text { Grout Disposal Vaults 106- } \\
109\end{array}$ & $\begin{array}{l}\text { This project constructs four grout disposal } \\
\text { vaul ts. }\end{array}$ \\
\hline 200 East & 1990 & $H-024 H$ & $\begin{array}{l}8 \text { Plant Radiological } \\
\text { Effluent/Containment } \\
\text { Upgrades (HEC) }\end{array}$ & $\begin{array}{l}\text { This project provides radiological effluent } \\
\text { containment upgrades to B Plant. The project is } \\
\text { on hold and is presently being rescoped. }\end{array}$ \\
\hline 200 East & 1991 & $W-153$ & TRUEX Pilot Plant & $\begin{array}{l}\text { This project will demonstrate the TRUEX process } \\
\text { for pretreatment of Hanford Site tank wastes. } \\
\text { The pilot plant will be located in B Plant, } \\
\text { cell } 38 \text { (dissolution), and WESF, cells B and C } \\
\text { (solvent extraction). The project will clean out } \\
\text { these cells; package and dispose of resulting } \\
\text { solid and liquid waste from cell clean out; and } \\
\text { install dissolution, sludge washing, and solids- } \\
\text { liquid separation equipment in B Plant, cell } 38 \text {. }\end{array}$ \\
\hline 200 East & 1992 & $W-059$ & $\begin{array}{l}\text { B Plant Safety Class } \\
\text { Ventilation Upgrade }\end{array}$ & $\begin{array}{l}\text { This project provides ventilation upgrades to B } \\
\text { Plant. The project is on hold and is presently } \\
\text { being rescoped. }\end{array}$ \\
\hline 200 East & 1992 & $w-151$ & 101-Az Retrieval system & $\begin{array}{l}\text { This project provides two mixer pumps and a } \\
\text { transfer pump in tank } 241-A z-101 \text { to mobilize and } \\
\text { retrieve the waste. It also provides for removal } \\
\text { and burial or storage of the existing } \\
\text { thermocouple trees and transfer pump, and } \\
\text { replacement of the thermocouple trees. } \\
\text { strengthening of some of the remaining in-tank } \\
\text { components is required, and instrumentation to } \\
\text { monitor waste mobilization and in-tank forces } \\
\text { imposed by pump forces will be installed. }\end{array}$ \\
\hline \multicolumn{5}{|c|}{ Budgeted Projects } \\
\hline \multicolumn{5}{|c|}{ Site Support } \\
\hline 200 West & 1993 & $W-087$ & $\begin{array}{l}\text { Radioactive Liquid Waste } \\
\text { Line Replacement }\end{array}$ & $\begin{array}{l}\text { This project will replace the radioactive waste- } \\
\text { drain piping from the hot cells in } \\
222-5 \text { Laboratory to the } 2195 \text { Waste Handl ing } \\
\text { Facility. The project will also install a new } \\
\text { waste transfer line from } 2195 \text { to the } 2445 \text { Catch } \\
\text { Station. }\end{array}$ \\
\hline 200 East & 1993 & $R-003$ & $\begin{array}{l}200 \text { East Unsecured Core } \\
\text { Area Fabrication Shop }\end{array}$ & $\begin{array}{l}\text { This project constructs } 51,000 \mathrm{ft}^{2} \text { fabrication } \\
\text { shop. The centralized shop will replace oging } \\
\text { facilities in the } 3000 \text { Area. }\end{array}$ \\
\hline 200 East & 1994 & $L-091$ & 200 East Office Facility & $\begin{array}{l}\text { This project will provide a replacement office } \\
\text { facility in the } 200 \text { East unsecured cose area. } \\
\text { The facillity, approximately } 60,000 \text { ft } t^{2} \text {, will } \\
\text { consist of three-story building for } \\
\text { approximately } 250 \text { employees. site preparations } \\
\text { will include parking space for } 250 \text { vehicles, } \\
\text { landscaping, and site stabilization. The project } \\
\text { will also provide the demolition of five } \\
\text { buildings and removal of four mobile office } \\
\text { facilities. }\end{array}$ \\
\hline
\end{tabular}


Table 2-6. 200 Areas Construction Projects

(More than \$1.2 Million). (sheet 5 of 8)

\begin{tabular}{|c|c|c|c|c|}
\hline Area & $\begin{array}{l}\text { Fiscal } \\
\text { year } \\
\text { budget }\end{array}$ & $\begin{array}{l}\text { Project } \\
\text { number }\end{array}$ & Project title & Project description \\
\hline \multicolumn{5}{|c|}{ Solid and Liquid Waste } \\
\hline 200 West & 1993 & $w-152$ & $\begin{array}{l}\text { Fy } 1993-1996 \text { Groundwater } \\
\text { Monitoring Wells }\end{array}$ & $\begin{array}{l}\text { This project will provide groundwater monitoring } \\
\text { systems for hazardous, mixed and radioactive } \\
\text { waste disposal sites. The system will be } \\
\text { constructed to comply with the RCRA and WAC } \\
\text { groundwater monitoring regulations. During the } \\
\text { calendar years } 1993 \text { through } 1996,240 \text { groundwater } \\
\text { monitoring wells will be constructed at a rate of } \\
60 \text { wells per year. }\end{array}$ \\
\hline 200 East & 1994 & $w-112$ & $\begin{array}{l}\text { Enhanced RMW Storage } \\
\text { Facility Phase V }\end{array}$ & $\begin{array}{l}\text { This project will construct lag storage for WRAP } \\
\text { operations and store sol id wastes awaiting } \\
\text { treatment, and provide infrastructure upgrades to } \\
\text { support the Hanford Central Waste Complex. }\end{array}$ \\
\hline 200 West & 1994 & $W-113$ & $\begin{array}{l}\text { Solid Waste Retrieval } \\
\text { Facility Phase I }\end{array}$ & $\begin{array}{l}\text { This project will provide the required retrieval } \\
\text { of suspect transuranic waste from one underground } \\
\text { location (trench) for processing at the WRAP } \\
\text { Facility. }\end{array}$ \\
\hline 200 West & 1994 & $W-100$ & WRAP Facility, Module $2 A$ & $\begin{array}{l}\text { This project will construct a facility that will } \\
\text { provide characterization, packaging, and } \\
\text { treatment required for process effluent streans. }\end{array}$ \\
\hline \multicolumn{5}{|c|}{ Tank Waste Remediation System } \\
\hline 200 & 1993 & $W-058$ & $\begin{array}{l}\text { Replacement of the Cross- } \\
\text { site Transfer system }\end{array}$ & $\begin{array}{l}\text { This project provides two encased stainless steel } \\
\text { transfer pipelines ( } 6.5 \mathrm{mi} \text { route), diversion } \\
\text { boxes, booster pumps, leak detection, and } \\
\text { cathodic protection per current codes and } \\
\text { standards. }\end{array}$ \\
\hline 200 East & 1993 & $W-2364$ & $\begin{array}{l}\text { Multi-Function Waste Tank } \\
\text { Facility }\end{array}$ & $\begin{array}{l}\text { Provides new underground storage tanks, which } \\
\text { will provide additional waste } \\
\text { storage/pretreatment capacity needed for the } \\
\text { resolution of tank safety issues. In addition, } \\
\text { the facillity will be used for limited } \\
\text { pretreatment, and waste staging and/or storage in } \\
\text { support of the HWVP. Each underground tank } \\
\text { system shall consist of three concentric } \\
\text { structures, and shall be provided with a } \\
\text { ventilation system, process piping, and } \\
\text { components. This facility will contain all } \\
\text { essential support systems, inter-tie piping, and } \\
\text { sampling systems. }\end{array}$ \\
\hline 200 East & 1993 & $w-276$ & $\begin{array}{l}\text { Grout Disposal Vaults } 110- \\
115\end{array}$ & $\begin{array}{l}\text { This project constructs six grout disposal } \\
\text { vaults. }\end{array}$ \\
\hline 200 East & 1994 & $H-211$ & $\begin{array}{l}\text { Initial Tanks Retrieval } \\
\text { Systems }\end{array}$ & $\begin{array}{l}\text { This project will provide retrieval capability to } \\
\text { remove radioactive waste from underground storage } \\
\text { tanks. The project provides system design, } \\
\text { equipment procurement, equipment installation, } \\
\text { and retrieval operations for } 10 \text { underground } \\
\text { storage tanks. Tank safety issues will be } \\
\text { mitigated before initiating waste renoval. } \\
\text { Retrieval systems will be developed to mobilize } \\
\text { settled solids, mix them into solution, and } \\
\text { transfer the tank contents to pretreatment or } \\
\text { other processing facilities. }\end{array}$ \\
\hline 200 East & 1994 & $W-174$ & $\begin{array}{l}\text { Low-Level Waste Disposal } \\
\text { Facility }\end{array}$ & $\begin{array}{l}\text { This project will provide a facility for disposal } \\
\text { of high activity, LLH. }\end{array}$ \\
\hline
\end{tabular}


Table 2-6. 200 Areas Construction Projects

(More than \$1.2 Million). (sheet 6 of 8 )

\begin{tabular}{|c|c|c|c|c|}
\hline Area & $\begin{array}{l}\text { Fiscal } \\
\text { year } \\
\text { budget }\end{array}$ & $\begin{array}{l}\text { Project } \\
\text { number }\end{array}$ & Project title & Project deecription \\
\hline \multicolumn{5}{|c|}{ Planned Projects } \\
\hline \multicolumn{5}{|c|}{ Site Support } \\
\hline 200 East & 1995 & $L-011$ & $\begin{array}{l}\text { Rail road Maintenance } \\
\text { Facility }\end{array}$ & $\begin{array}{l}\text { This project would construct a railroad } \\
\text { maintenance facility for the purpose of } \\
\text { preventive and corrective maintenance of rail road } \\
\text { equipment. }\end{array}$ \\
\hline 200 East & 1995 & $L-103$ & office/Training facility & $\begin{array}{l}\text { This project will construct an office/training } \\
\text { facility in the } 200 \text { East Ares. }\end{array}$ \\
\hline 600 & 1995 & $L-102$ & $\begin{array}{l}\text { Primary Highway Route } \\
\text { North of the Wye Barricade }\end{array}$ & $\begin{array}{l}\text { This project will upgrade the primary highway } \\
\text { north of the Wye Barricade, bring the highwoy } \\
\text { into compliance with Washington State Department } \\
\text { of Transportation. }\end{array}$ \\
\hline 200 East & 1996 & $L-116$ & $\begin{array}{l}200 \text { Area Sanitary Sewer } \\
\text { System }\end{array}$ & $\begin{array}{l}\text { This project will install a sanitary sewer } \\
\text { coll ection system and construct a treatment } \\
\text { system. The project will replace the use of } \\
\text { sept ic tank and drainfield systems in the } \\
200 \text { Areas. }\end{array}$ \\
\hline 200 East & 1996 & $R-004$ & $\begin{array}{l}\text { Kaiser Engineers Hanford } \\
200 \text { East Office Facility }\end{array}$ & $\begin{array}{l}\text { This project will provide new } 60,000 \mathrm{ft}^{2} \text { office } \\
\text { facillity. The facility will house approximately } \\
250 \text { employees. }\end{array}$ \\
\hline 200 East & 1997 & $L-022$ & $\begin{array}{l}\text { Hazardous Materials } \\
\text { Harehouse }\end{array}$ & $\begin{array}{l}\text { This project would consolidate commercial } \\
\text { herbicide and pesticide chemicals on the Henford } \\
\text { site. }\end{array}$ \\
\hline 200 East & 1997 & $L-X X X$ & Office/Support Facility & $\begin{array}{l}\text { This project will provide new } 60,000 \mathrm{ft}^{2} \text { office } \\
\text { facility. The facility will house approximately } \\
250 \text { employees. }\end{array}$ \\
\hline 200 East & 1998 & $L-117$ & $\begin{array}{l}\text { General Support and } \\
\text { Electrical Utilities } \\
\text { Complex }\end{array}$ & 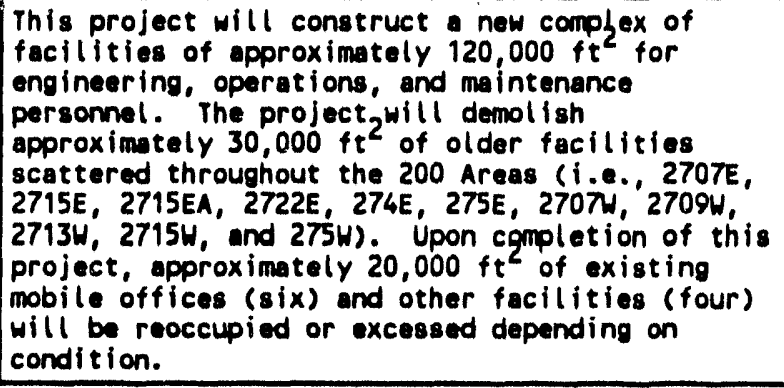 \\
\hline \multicolumn{5}{|c|}{ Solid and Liquid Waste } \\
\hline 200 West & 1995 & c-or7 & $\begin{array}{l}\text { T Plant Ventilation } \\
\text { Upgrade }\end{array}$ & $\begin{array}{l}\text { This project will correct the air supply, } \\
\text { distribution, exheust, and pressure control } \\
\text { problems within the } 221-\mathrm{T} \text { Canyon. }\end{array}$ \\
\hline 200 West & 1995 & $c \cdot 116$ & PFP Waste Water Disposal & $\begin{array}{l}\text { This project will provide methods to achieve zero } \\
\text { discharge to the } 2-20 \text { Crib. The methods will be } \\
\text { for both interim and final disposal. }\end{array}$ \\
\hline 200 West & 1995 & $W-255$ & WRAP Facilities, Module 28 & $\begin{array}{l}\text { This project will construct a facility that will } \\
\text { provide characterization, packaging, and } \\
\text { treatment required for disposal of transuranic } \\
\text { waste. }\end{array}$ \\
\hline
\end{tabular}


Table 2-6. 200 Areas Construction Projects

(More than $\$ 1.2$ Million). (sheet 7 of 8 )

\begin{tabular}{|c|c|c|c|c|}
\hline Area & $\begin{array}{l}\text { Fiscal } \\
\text { year } \\
\text { budget }\end{array}$ & $\begin{array}{l}\text { Project } \\
\text { number }\end{array}$ & Project title & Project description \\
\hline 200 West & 1995 & $W-253$ & $\begin{array}{l}\text { Plant Waste Water } \\
\text { Modifications }\end{array}$ & $\begin{array}{l}\text { This project supports the plan to discontinue } \\
\text { disposal of contaminated liquids into the soil } \\
\text { colum. The project will eliminate the T Plant } \\
\text { pressurized water reactor cool ing water; provide } \\
\text { a connection of the T Plant waste water and } \\
T \text { Plant laboratory waste water systems to the } \\
\text { TEDF; reline or replacement of active chemical } \\
\text { sewer piping to prevent movement of potentially } \\
\text { existing radionuclides contaminat lon of the } \\
\text { piping to the soil column; refurbishment of the } \\
207 \text { basin to collect and monitor the T Plant } \\
\text { waste water before connection to the TEDF; } \\
\text { transfer of potentially radionuclides- } \\
\text { contaminated T Plant floor drain, sump, and steam } \\
\text { condensate contributions to tank farms. }\end{array}$ \\
\hline 200 West & 1995 & $W-259$ & $\begin{array}{l}\text { T Plant Secondary } \\
\text { Containment and Leak } \\
\text { Detection }\end{array}$ & $\begin{array}{l}\text { This project will upgrade key operational areas } \\
\text { of T Plant to comply with secondary containment } \\
\text { and leak detection of dangerous waste } \\
\text { constituents as defined by Washington state } \\
\text { Department of Ecology. Some of the areas at } \\
\text { T Plant that will be upgraded are the } 2706 \mathrm{~T} \\
\text { railroad and automotive pits, } 2111 \text { sludge } \\
\text { collection sump, transfer piping, railroad } \\
\text { turnel, piping trench, process cells, Cell 5R } \\
\text { sump, and tank 5-7. }\end{array}$ \\
\hline 200 West & 1996 & $W-252$ & $\begin{array}{l}\text { Phase II Liquid Effluent } \\
\text { Treatment Facility }\end{array}$ & $\begin{array}{l}\text { This project will construct collection, storage, } \\
\text { treatment, and disposal facilities for process } \\
\text { effluent streans. }\end{array}$ \\
\hline 200 West & 1996 & $w-221$ & $\begin{array}{l}\text { Solid Waste Retrieval } \\
\text { Facility, Phase II }\end{array}$ & $\begin{array}{l}\text { This project will retrieve transuranic waste from } \\
\text { burial grounds. }\end{array}$ \\
\hline 200 West & 1996 & $W-242$ & $\begin{array}{l}\text { Solid Waste Thermal } \\
\text { Treatment }\end{array}$ & $\begin{array}{l}\text { This project will provide high-temperature } \\
\text { disposal of mixed waste. }\end{array}$ \\
\hline 200 East & 1997 & $W-156$ & Alphe Caisson Retrieval & $\begin{array}{l}\text { This project will provide for retrieval of a } \\
\text { large quantity of the high-dose-rate waste using } \\
\text { a movable confinement structure that has } \\
\text { appropriate shielding to minimize risk to } \\
\text { operations staff and the enviroment. The } \\
\text { project will olso provide the casks that will be } \\
\text { used to move the retrieved wastes to the } \\
\text { processing facillty. }\end{array}$ \\
\hline \multicolumn{5}{|c|}{ Tank Waste Remediation System } \\
\hline 200 East & 1995 & TBD & $\begin{array}{l}\text { Multi-Purpose Storage } \\
\text { Facility }\end{array}$ & $\begin{array}{l}\text { This project will consol idate the storage of } \\
\text { nuclear fuels, cesium strontium capsules, glass } \\
\text { canisters from HWVP, and plutonium residuals at a } \\
\text { central location on the Hanford Site. }\end{array}$ \\
\hline 200 East & 1995 & $w-139$ & 241-C-106 Waste Retrieval & $\begin{array}{l}\text { This project provides the retrieval system, } \\
\text { supporting utillity systems, tank modifications, } \\
\text { test facility, and waste transfer line required } \\
\text { to remove } 95 \text { percent of the waste from tank } 241 \text {. } \\
\text { C-106, and transfer the waste to the DST system } \\
\text { for subsequent processing. }\end{array}$ \\
\hline 200 West & 1995 & $W-188$ & $\begin{array}{l}\text { Tank farms Radiological } \\
\text { Support Facilities }\end{array}$ & $\begin{array}{l}\text { This program will construct access control, } \\
\text { changeroom, shop, equipment storage, computer } \\
\text { workstation, local alarm, data display, and } \\
\text { control facilities for more than } 10 \text { tank farms in } \\
\text { the } 200 \text { East and } 200 \text { West Areas. }\end{array}$ \\
\hline
\end{tabular}


Table 2-6. 200 Areas Construction Projects

(More than \$1.2 Million). (sheet 8 of 8 )

\begin{tabular}{|c|c|c|c|c|}
\hline Area & $\begin{array}{l}\text { Fiscal } \\
\text { year } \\
\text { budget }\end{array}$ & $\begin{array}{l}\text { Project } \\
\text { number }\end{array}$ & Project title & Project description \\
\hline 200 East & 1995 & $W-236 B$ & $\begin{array}{l}\text { Initial Pretreatment } \\
\text { Module }\end{array}$ & $\begin{array}{l}\text { This project provides a new radiochemical process } \\
\text { facility designed to resolve Hanford site tank } \\
\text { waste issues and provide capability to prepare } \\
\text { liquid high-level radioactive defense waste for } \\
\text { final treatment in either a grout or borosilicate } \\
\text { glass waste form. This facillity will contain all } \\
\text { essential support systems, inter-tie piping, and } \\
\text { sampling systems. This project will provide for } \\
\text { pretreetment systems to destroy or modify waste } \\
\text { from safety issue tanks to acceptable } \\
\text { storage/disposal forms. }\end{array}$ \\
\hline 200 West & 1995 & $W-201$ & Transfer System Upgrades & $\begin{array}{l}\text { This project replaces approximately } 15,000 \mathrm{ft} \text { of } \\
\text { encased waste transfer lines from T Plant and } \\
\text { miscel laneous segments of pipel ine to support all } \\
\text { waste transfers. The project includes diversion } \\
\text { boxes, leak detection, and cathodic protection } \\
\text { per current codes and standards. }\end{array}$ \\
\hline 200 West & 1995 & $W-260$ & $\begin{array}{l}\text { New DST Farm, } 200 \text { West } \\
\text { Area }\end{array}$ & $\begin{array}{l}\text { This project will provide additional DSTs to } \\
\text { replace existing tanks and expand capacity. }\end{array}$ \\
\hline
\end{tabular}

DST = Double-shell tank.

FY = Fiscal year.

HEC = Hanford Environmental Compl iance.

HEPA = High-efficiency particulate air (filter).

HVAC = Heating, ventilation, and oir conditioning.

HWNP = Hanford Haste Vitrification Plant.

PFP = Plutonium Finishing Plant.

PUREX = Plutonium-Uranium Extraction.

RCRA = Resource Conservation and Recovery Act of 1976.
RMW = Radioactive mixed waste.

SST = single-shell tank.

$T B D=$ To be determined.

TEDF = Treated Effluent Disposal Facility.

TRUEX = Transuranic extraction.

WAC = Hashington (state) Acministrative Code

WESF = Waste Encapsulation and Storage Facility.

WRAP = Waste Receiving and Processing. 
Figure 2-2. Construction Projects Planned in the 200 East Area.

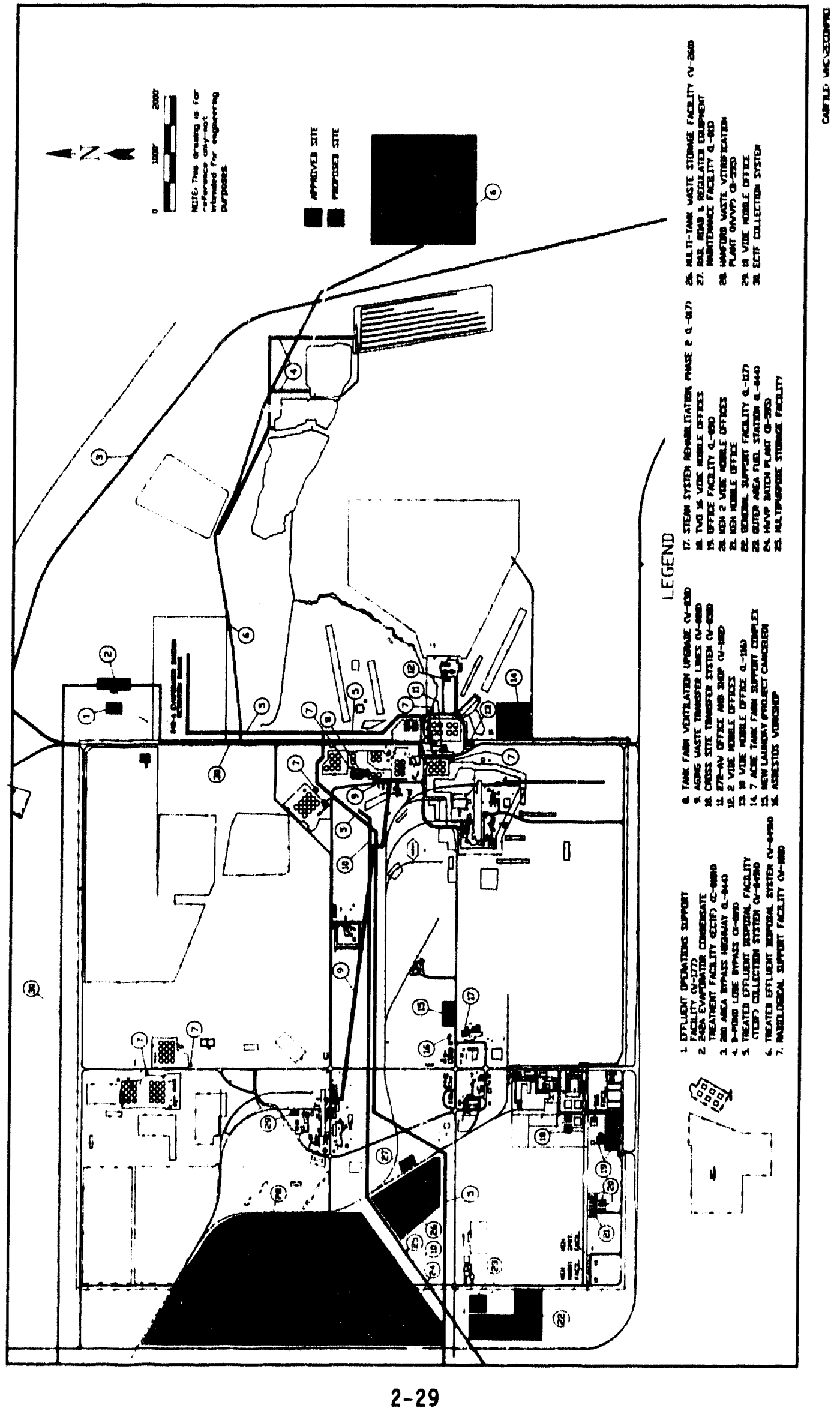


Figure 2-3. Construction Projects Planned in the 200 Area Corridor.

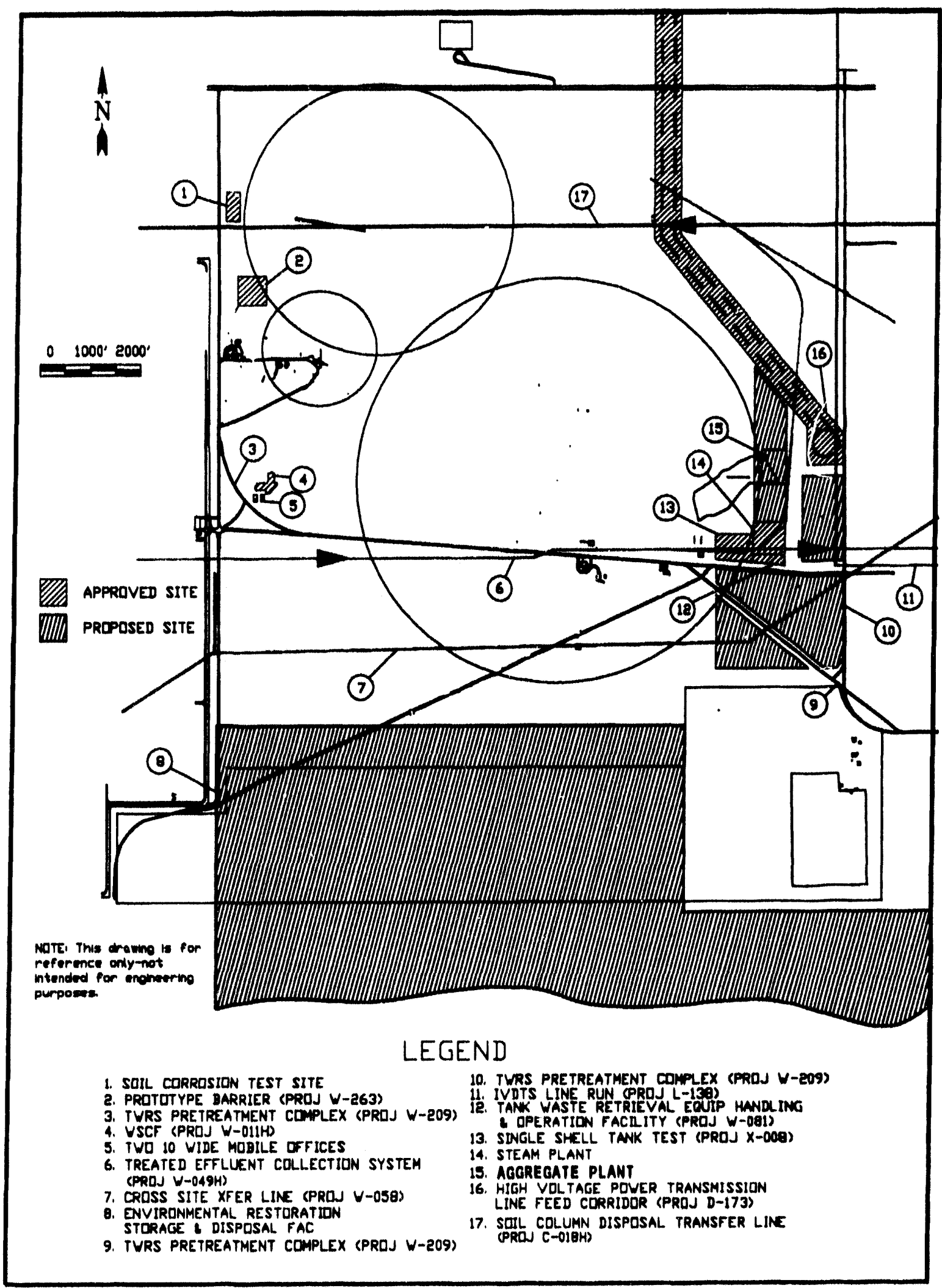


Figure 2-4. Construction Projects Planned in the 200 West Area.

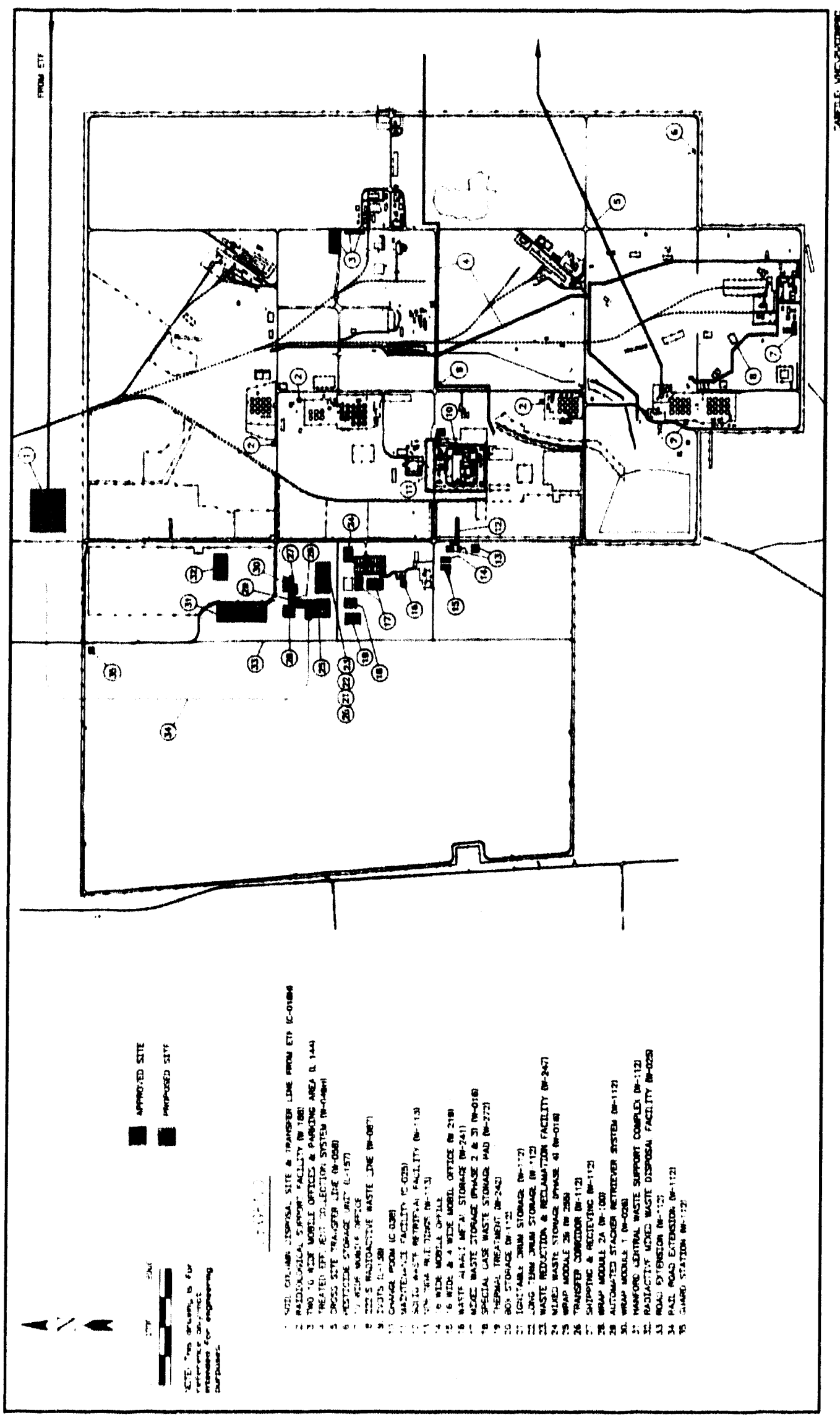


2.3.3.1 Transportation Routes. This section identifies existing traffic routes in the 200 Areas and new road schemes to serve projected activities.

Existing Circulation. Figure 2-5 shows existing access routes to the 200 Areas. Figure 2-6 shows existing roads and rail in the 200 Areas. The main access from the south is via the Wye Barricade using Route $4 \mathrm{~S}$. A secondary access via the Wye Barricade is Route 25 to Route $11 \mathrm{~A}$. The main access road to this area from the north via the Yakima Barricade is Route $11 \mathrm{~A}$ directly or by combinations of Route $11 \mathrm{~A}$ and Route 3 or Route $4 \mathrm{~S}$. Access to the 200 East Area is via gate 810 at the northeast corner, gate 814 on the west side, and gate 815 on the south side. Access to the 200 West Area is via gate 609 on the north side and gate 612 on the east side. Access to the 200 Area Corridor is not controlled.

The roads within the 200 East and 200 West Areas run in a broken grid pattern; the north-south roads are named for cities and the east-west roads are numbered. These roads generally travel short distances and are commoniy broken by previous expansions to major operating facilities. Many of the roadways in the 200 East and 200 West Areas need to be resurfaced. In addition, many of the roadways are used for pedestrian traffic because of the lack of sidewalks. The condition of these roads ranges irom fair to poor.

Private parking in the 200 Areas is primarily located at each facility with adequate walkways to the buildings. Vehicles must park outside of the security entrances to the PUREX Plant and PFP. Provisions for walkways are marginal inside these compounds, but vehicular traffic volumes are low. While some private vehicle parking is available adjacent to offices in the 200 East Core Area, most people working there must park outside the limited area fence and walk through the guard station at gate 815 , or they must park in the gravel lot north of the $2101 \mathrm{M}$ Building. In general, walkways between buildings are marginal.

Approximately $24.0 \mathrm{~km}$ (14.9 $\mathrm{mi})$ of rallroad track runs within the 200 Areas. The rail system transports coal to the powerhouses, waste to burial grounds, and equipment and materials to major work centers. The railroad system trackage is generally sound. Maintenance levels vary with use. For instance, the spurs to the powerhouses are well maintained while some sections of track through burial grounds are covered with potentially contaminated blow sand.

Road and Rail Changes. This Development Plan assumes that a new road between Route 11A and Route $4 S$ will be built just east of the 200 East Area and that significant upgrades will be made to the remaining road sections between the Wye and Yakima Barricades (Figure 2-7). These will be required to support the projected traffic for the 200 Areas and to support the heavy hauling loads for burial ground closure activities. 
$D O E / R L-92-29$

Figure 2-5. Existing Access to the 200 Areas.

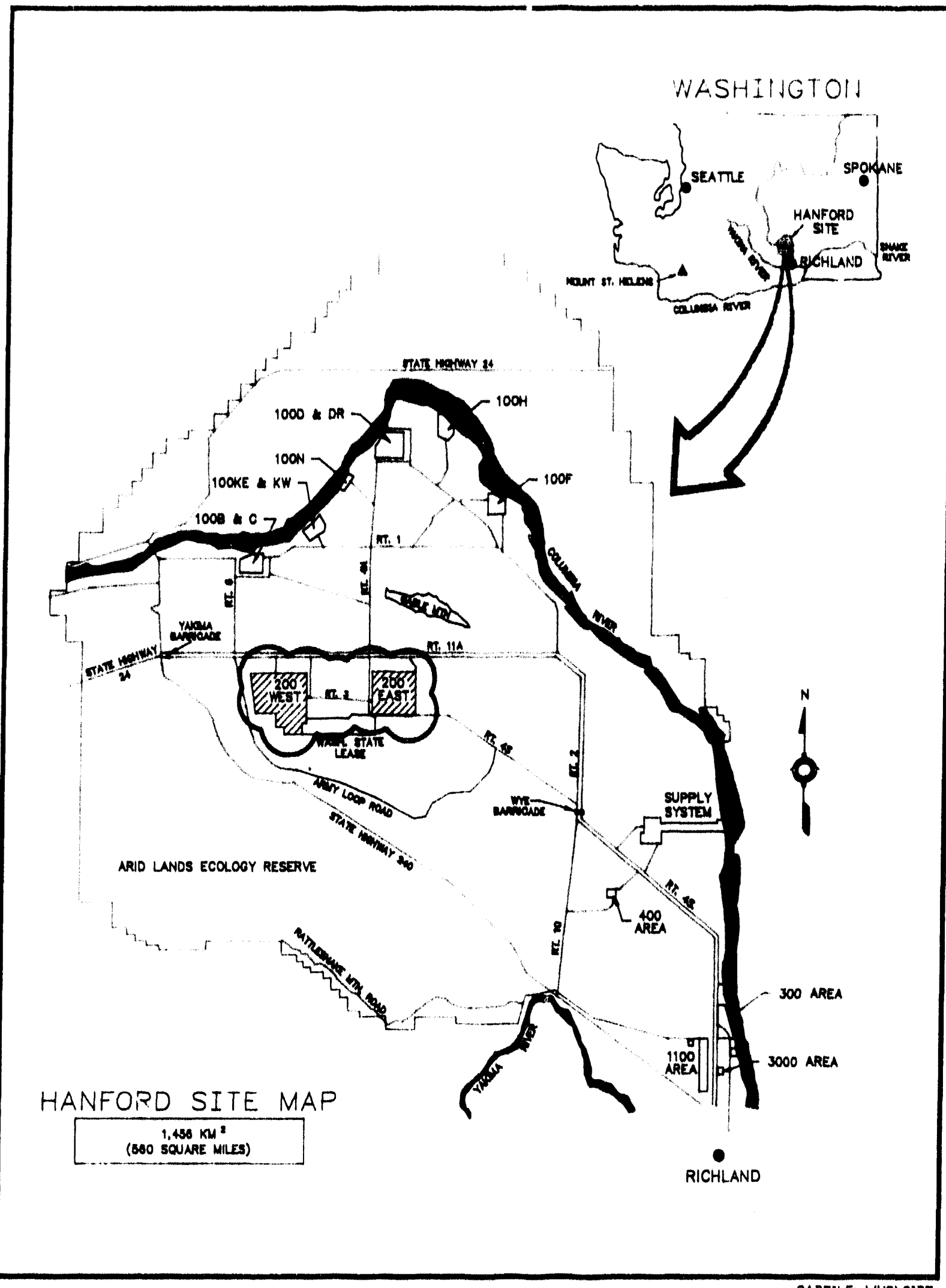

CADFILEI WHCISITE 
DOE/RL-92-29

Figure 2-6. Existing Roads and Rail in the 200 Areas.
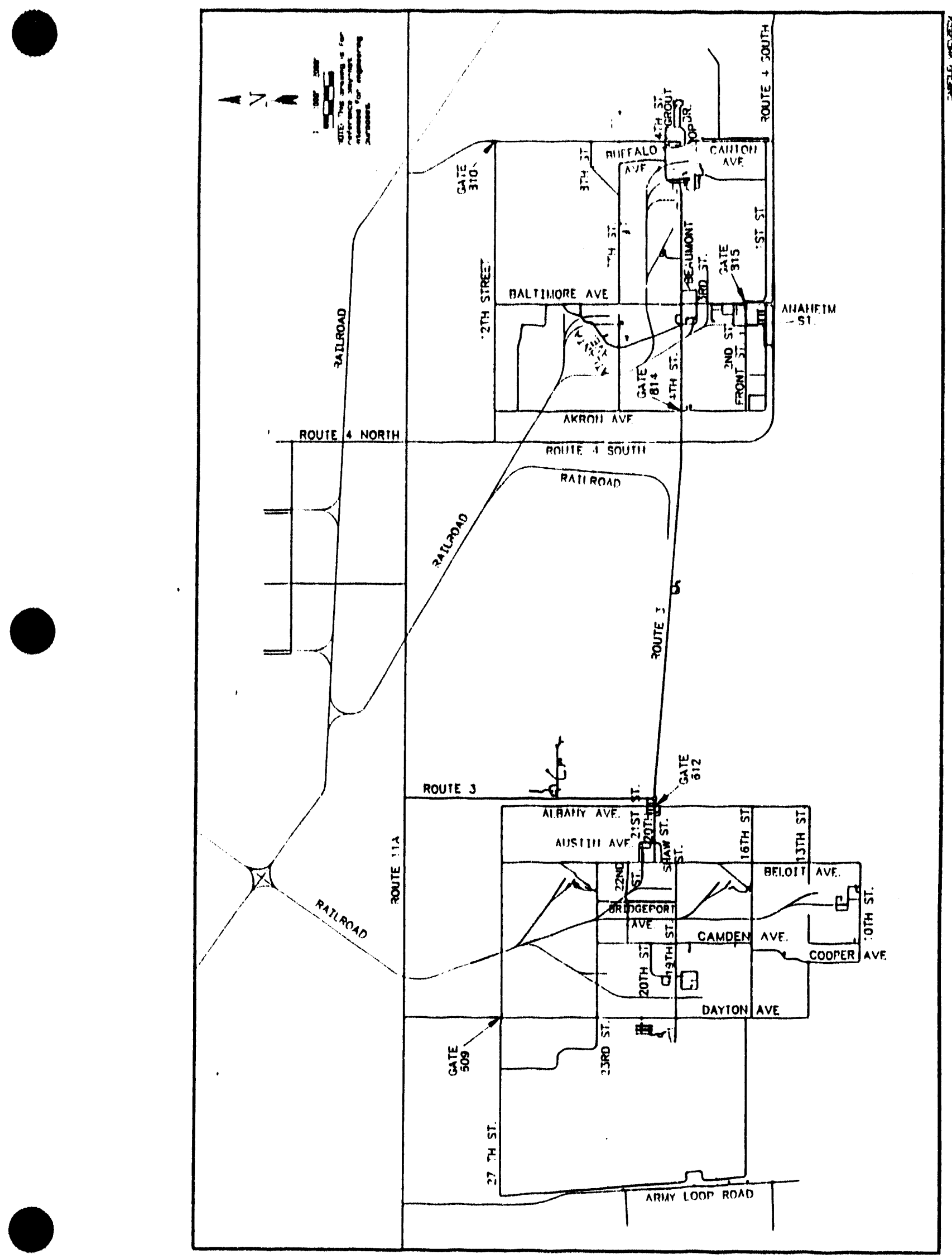


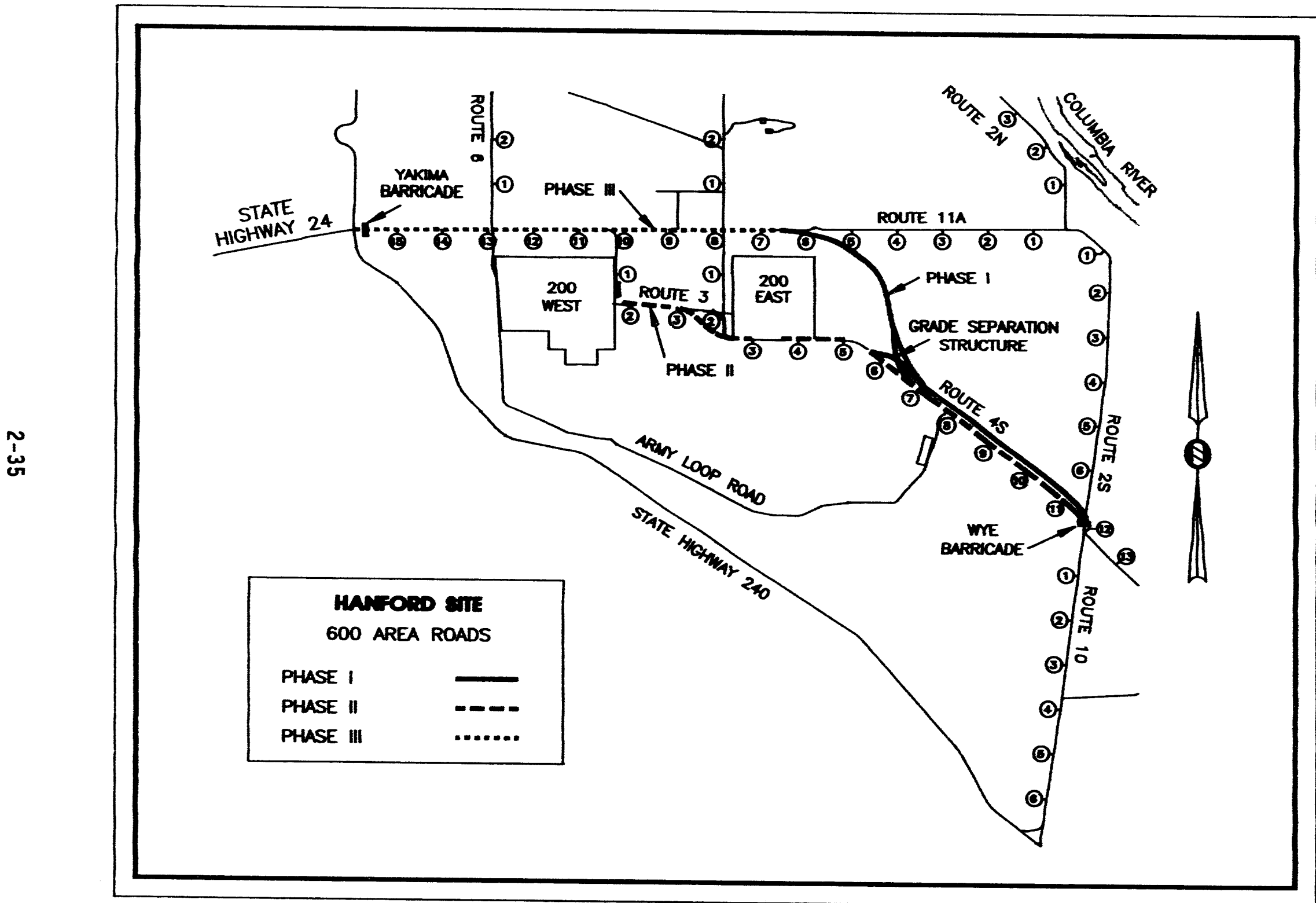

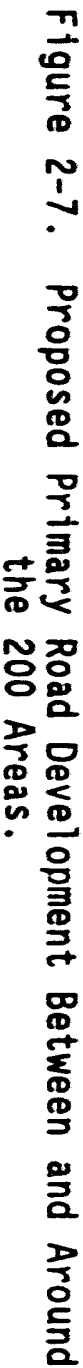


Existing burial grounds will be closed and covered. Some roads and rail lines adjacent to these burial grounds will need to be relocated to allow room for the down slope at the edge of the burial ground covers. Dayton Avenue in the 200 West Area will be closed to through traffic when TRU retrieval activities begin. A new north access to the 200 West Area will be installed to provide easy access to the HCWC and to get around road blocks caused by burial ground retrieval and closure activities. Main roads to burial grounds will require upgrades to support large volumes of heavy hauling. Figures 2-8 and 2-9 show anticipated road and rail closures, relocations, and new road construction in 200 East and 200 West Areas, respectively.

The infrastructure in the 200 Area Corridor needs to be built up from the backbone along Route 3 . Tank Waste Remediation System facilities are expected to be constructed along the cross-site transfer line. Road and rail service should parallel this route. Another road could be built along the boundary between the corridor and the State-leased land to allow further development of the south end of the corridor area and to encourage development of the leased land. Figure 2-10 shows a conceptual layout of roads and rail for the 200 Area Corridor.

2.3.3.2 Utilities. This section identifies utilities serving the 200 Areas. Utilities include water, telecommunications, electrical, steam, and sewer.

2.3.3.2.1 Water. Most of the 200 Areas' water systems were constructed in 1944. Systems were designed to support the high demand chemical processing operations. New requirements for water are expected to be met by the capacities made available by the reduction in chemical processing requirements. For instance, $15,141.6$ to $22,712.4 \mathrm{~L} / \mathrm{min}(4,000$ to $6,000 \mathrm{gal} / \mathrm{min}$ ) of capacity will become available for other use upon completion of activities at the PUREX Plant. The Hanford Site Infrastructure Plan (DOE-RL 1990b) contains a detailed description of the water systems.

The existing 200 Areas' water system, with upgrades identified below, is expected to continue to serve the areas for the foreseeable future. Suppiy, storage, pumping, and distribution components will be evaluated continualiy for adequacy and condition to ensure the availability of raw and sanitary wuter to activities in these areas. Replacement of the majority of the $43.47 \mathrm{~km}$ ( $27 \mathrm{mi}$ ) of steel piping will probably be required before the

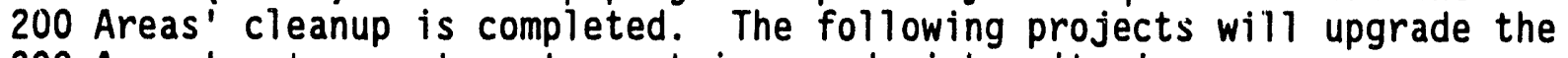
200 Areas' water systems to meet improved risk criteria.

\begin{tabular}{|c|l|l|r|} 
Project & \multicolumn{2}{c}{ Year } & \multicolumn{1}{c|}{ Description } \\
\hline L-005 & 1989 & East Area Water Laterals & $\$ 900,000$ \\
\hline L-007 & 1990 & Water System Safety Upgrade, 200W Laterals & $\$ 900,000$ \\
\hline B-604 & 1990 & Water System Upgrade Reservoir & $\$ 18,000,000$ \\
\hline
\end{tabular}

Figures 2-11 and 2-12 show existing and planned water distribution in the 200 East and 200 West Areas, respectively. Water distribution in the 200 Area Corridor will parallel the new roads (see Figure 2-10 for conceptual road plans). 
Figure 2-8. Future 200 East Area Roads and Rail.

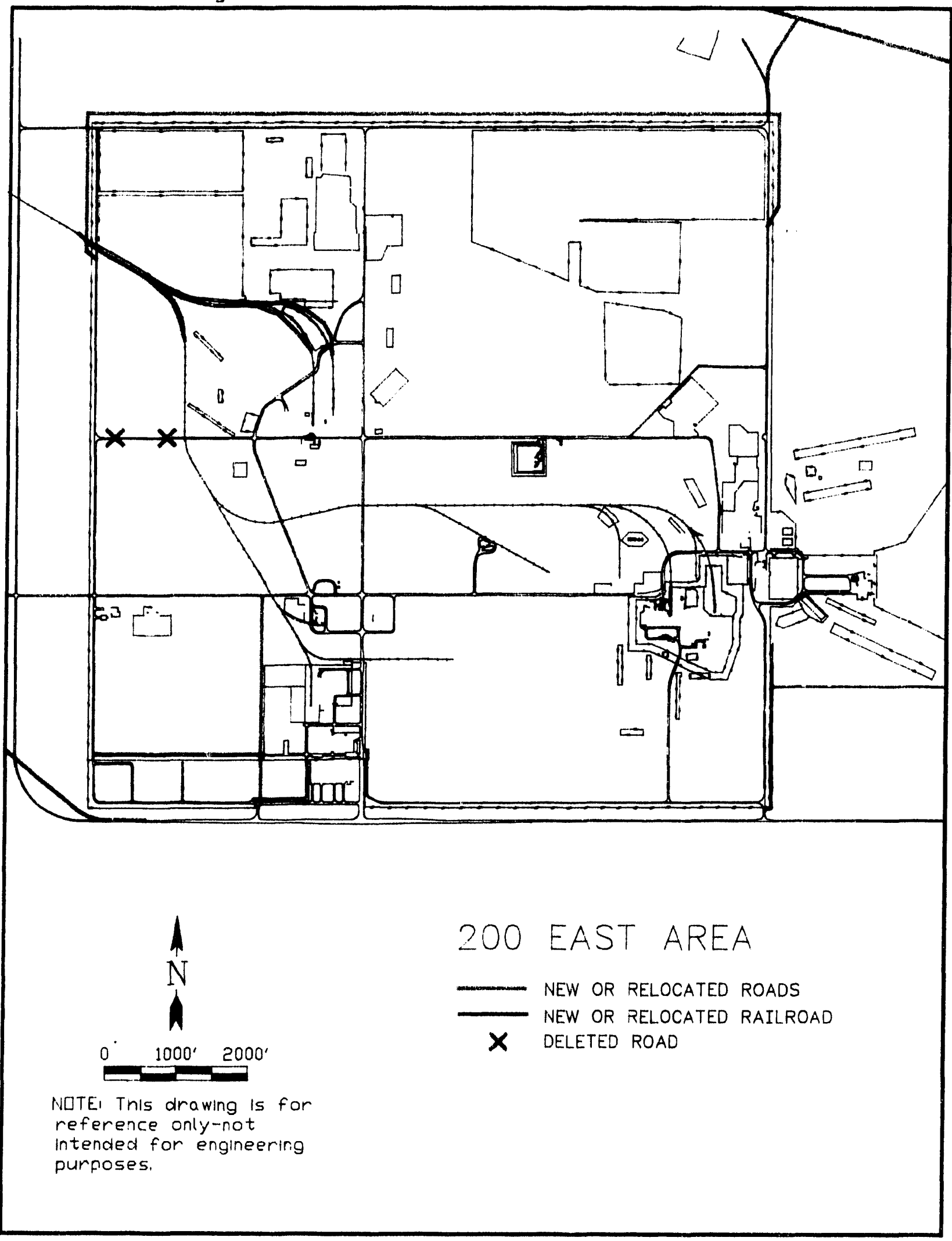


Figure 2-9. Future 200 West Area Roads and Rail.

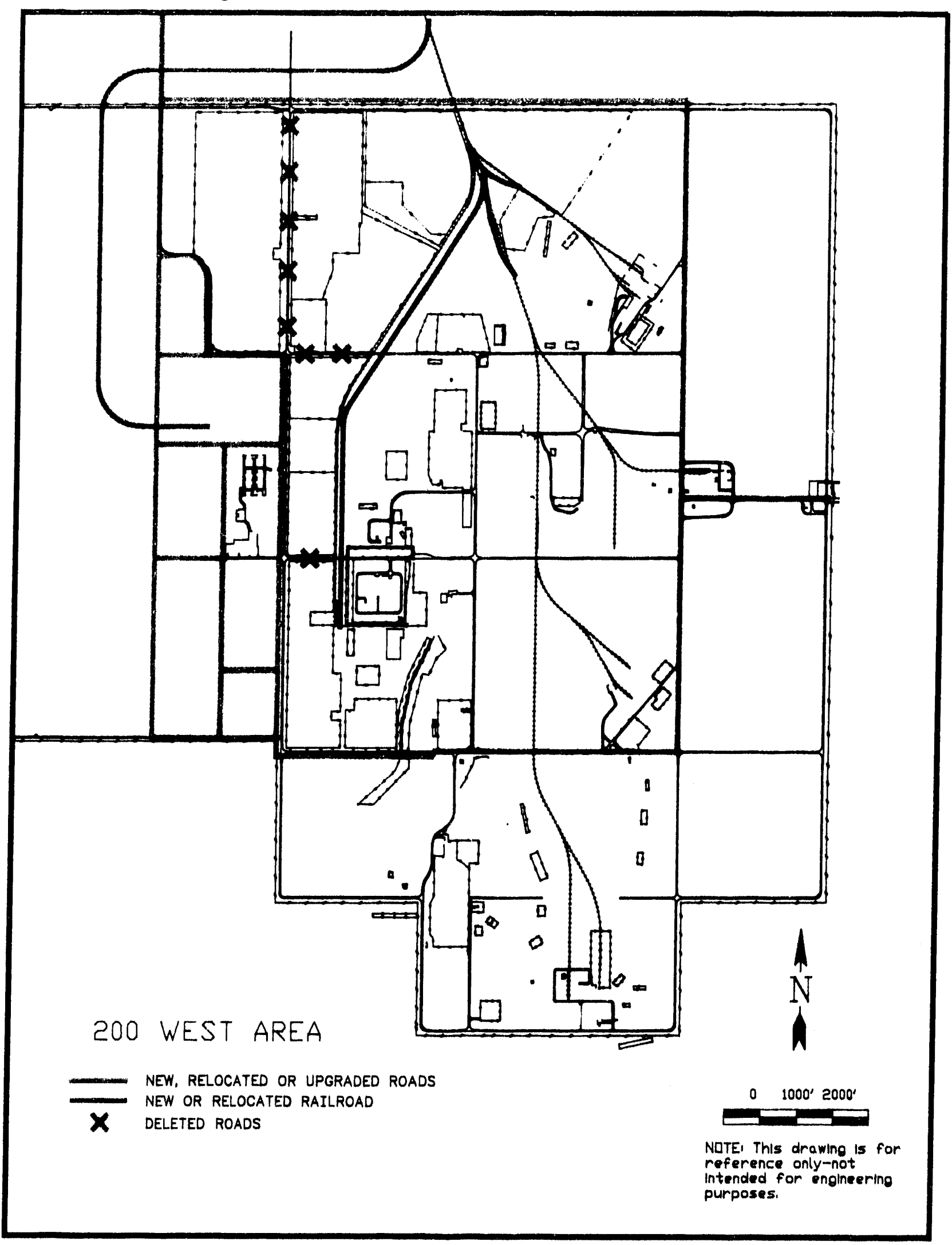


Figure 2-10. Conceptual Plan for Roads and Rail in 200 Area Corridor.

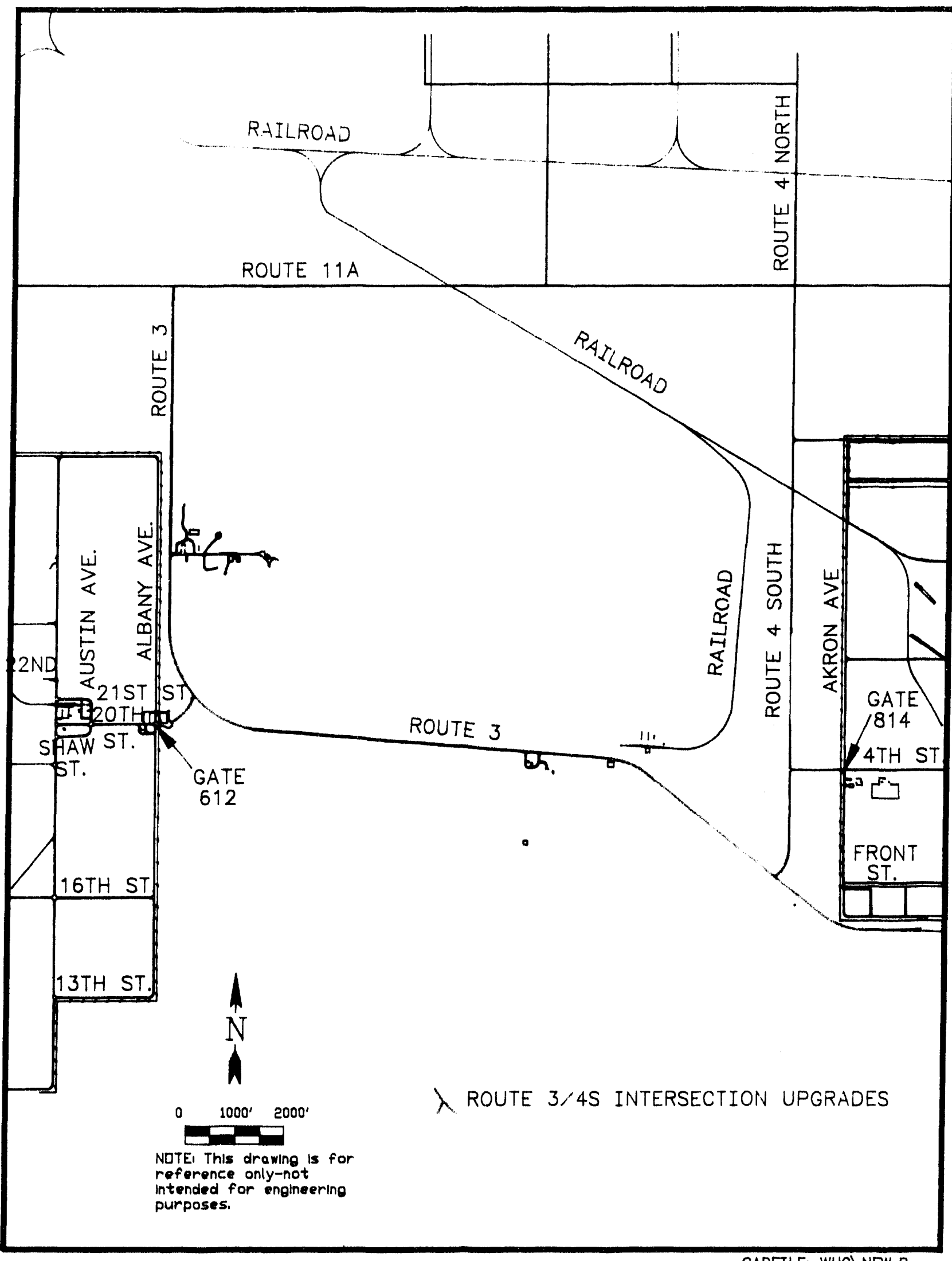


Figure 2-11. Existing and Planned 200 East Water System.

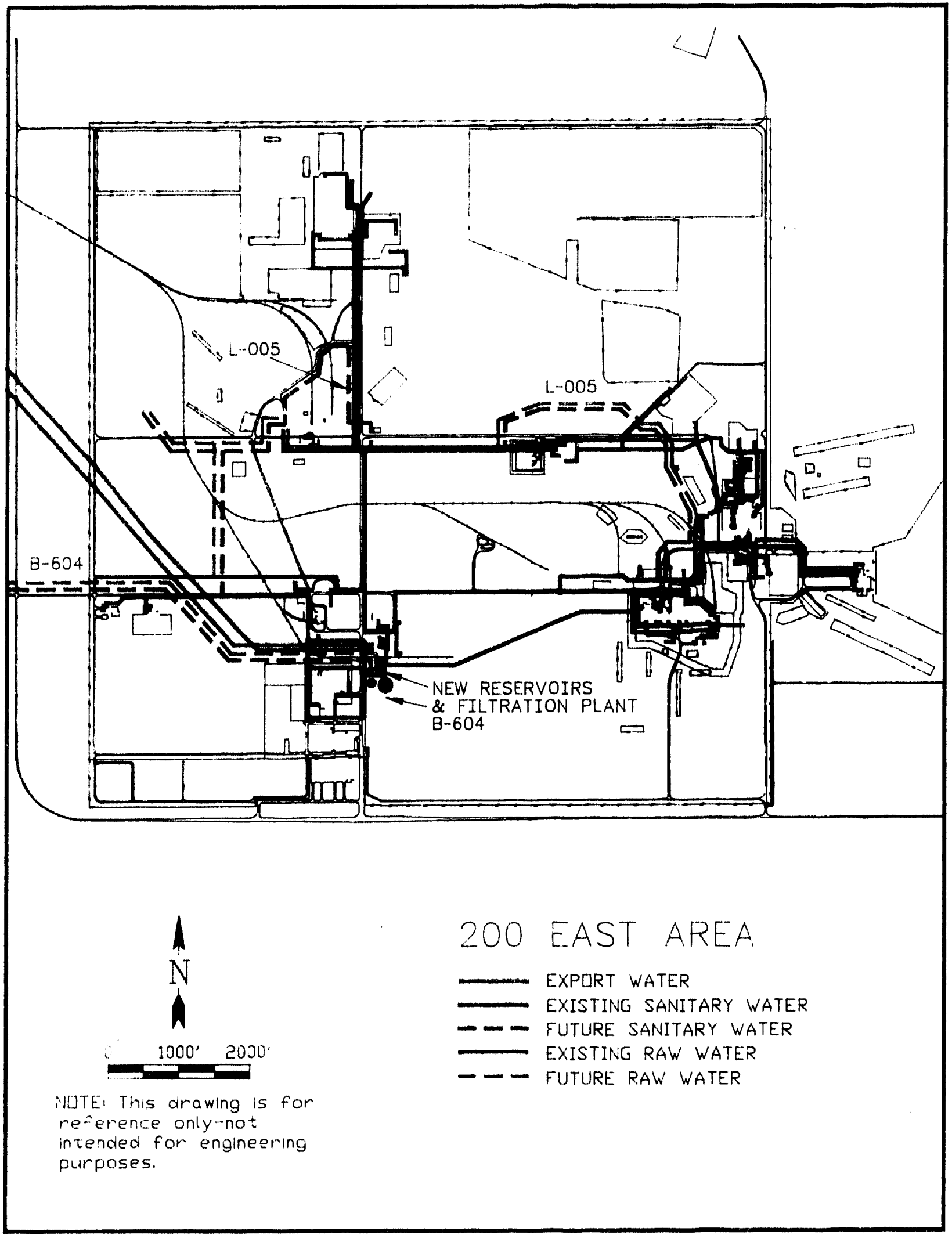


Figure 2-12. Existing and Planned 200 West Water System.

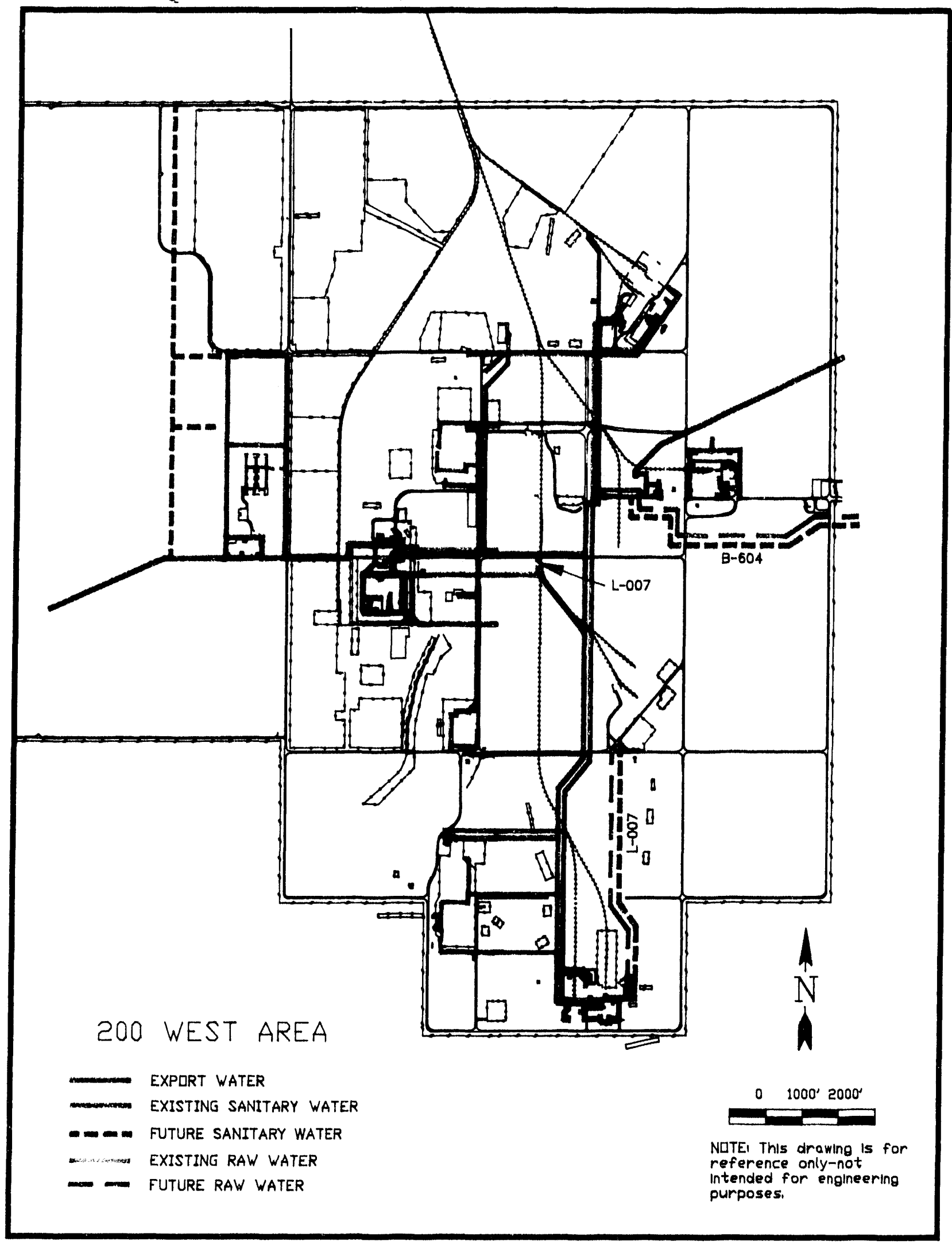


2.3.3.2.2 Telecommunications. The Integrated Voice and Data Telecommunications System will replace the current telecommunications system on the Hanford Site in FY 1993. The Integrated Voice and Data Telecommunications System will have the capability of standalone optical remote modules. Telephone and some data service will be provided by remote switching units (RSU) located in the 200 East and 200 West Areas. These RSUs will be connected via a fiber optic network to the host switching location within the 300 Area. Site space allocation will be required for the RSUs within 200 East and 200 West Areas. Intra-area Hanford Local Area Network (HLAN) data traffic will also use the interconnecting fiber optic cables to transmit data.

Message traffic in and out of the host to the FTS 2000 and public network will use either fiber optic cable or digital microwave radio. All message trunks to the RSUs, including the private lines, will use digital pulse code modulation carrier facilities. The private lines, tie trunks, and data 1 inks between the host and RSU will also be diverse routed using fiber optic cable facilities and digital microwave radio.

Transmission facilities for the HLAN will use existing and future fiber optic, coaxial, and microwave routing. Enhancement of the transmission rates and speeds will be evaluated as the technologies and hardware become available. Planning for landlord capital equipment not related to construction has been completed for FYs 1991 through 1993. The HLAN transmission facilities will be expanded based on future needs, costs, and functionality. Several fiber optic hub locations will be installed within buildings in each area. These hub locations will be established as points of distribution. Additional fiber optic cables will be extended from these hub locations to support high speed data requirements in their immediate areas.

Initial use of the fiber hub distribution networks will be to extend the $10 \mathrm{MB}$ Ethernet ${ }^{1}$ to locations within the hub serving areas. Transmission capabilities of the fiber routes and hubs are expected to be enhanced to $100 \mathrm{MB}$ speeds within the next 5 years.

Future facility requirements to support the telecommunications needs for the 200 Areas will consist of identifying and providing telecommunications rooms within building space to accommodate operating requirements for these various types of telecommunications equipment. This building space is required to be identified and provided on all new and existing (remodeled) structures within the 200 Areas.

Routing capability (easements), for main route fibers to interconnect the host switching system and the RSUs, and the HLAN and distribution routing to the new service locations will be required.

The HLAN equipment in the 200 Areas has more than doubled within the past 2 years. Additional support equipment, such as mail routers and monitoring units, have taxed the space, power, and cooling capacity of the existing facilities. Additional space for the HLAN hardware will be required to

\footnotetext{
${ }^{1}$ Trademark of Xerox Corporation.
} 
support continued expansion of the system. Growth of the data traffic on the HLAN within the 200 Areas is expected to require a minimum 100 Mbps by 1995 and 1 Gbps by 1999.

Figures 2-13 and 2-14 show existing and planned telecommunications distribution in the 200 East and 200 West Areas, respectively.

Telecommunications distribution in the 200 Area Corridor will parallel the new roads (see Figure 2-10 for conceptual road plans).

2.3.3.2.3 Electrical. Power to the 200 Areas comes from the 251-W Substation located just north of Route $11 \mathrm{~A}$ and approximately $2.25 \mathrm{~km}$ (1.4 mi) west of Route $4 \mathrm{~N}$. This substation is part of the Hanford Site 230-kV transmission loop.

The 251-W Substation has two 230-kV buses and two 230-kV to 13.8-kV transformers, each with a maximum rating of 50 MVA. Two 13.8-kV switchgear buses distribute 13.8-kV electrical power to the 200 Areas via overhead distribution power lines. Critical services are supplied electrical power by two distribution circuits, one from each of the 13.8-kV buses. The normally open 13.8-kV bus-tie breaker keeps both of the 13.8-kV buses independent. The two 230-kV power sources from two sides of the substation provide a reliable energy supply. The current peak demand at the 251-W Substation is $18 \mathrm{MW}$.

The distribution system is generally in fair to good condition. The following two projects are planned/proposed to improve safety, reliability, or capacity.

The Landlord Program is currently studying replacement of the $2,400-V$ systems in the 200 East and 200 West Areas with 13.8-kV systems. The project would also include replacing road and fence lighting.

Two 230-kV lines will be installed between the 251-W Substation and a new substation to be located southeast of the intersection of the export water lines and Route 4S. The new substation will be sized to support HWVP and be capable of expanding to meet the needs of proposed Tank Waste Remediation System facilities.

Figures 2-15 and 2-16 show existing and planned electrical distribution in the 200 East and 200 West Areas, respectively. Electrical power distribution in the 200 Area Corridor will parallel the new roads (see Figure 2-10 foi" conceptual road plans).

2.3.3.2.' Steam. Heating and process steam is supplied from two powerhouses, one in each area. The 200 East Area powerhouse has five coalfired boilers rated at a total of $325,000 \mathrm{lb} / \mathrm{h}$, and a short-term overload rating of $345,000 \mathrm{lb} / \mathrm{h}$ for 4 hours. In the 200 West Area, four boilers provide $260,000 \mathrm{lb} / \mathrm{h}$.

The existing steam plants, constructed in 1943, will not meet future space heating and process needs without significant upgrades. Because the 200 Areas will serve as the primary area for waste treatment and long-term storage, a reliable steam or alternative energy supply is critical. 
Figure 2-13. Existing and Planned Telecommunications in the 200 East Area.

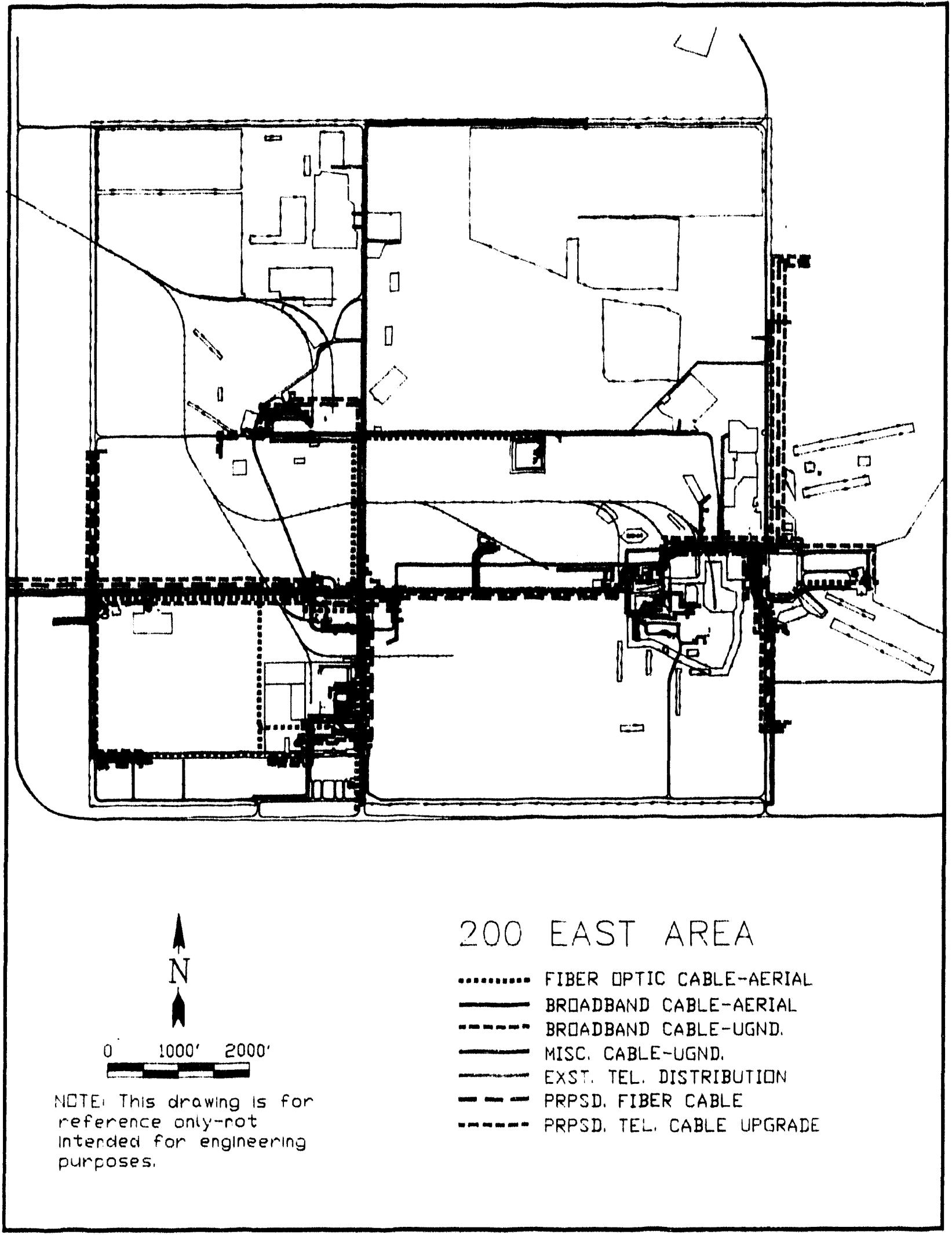

CADFILEI WHC \2OCE 
Figure 2-14. Existing and Planned Telecommunications in the 200 West Area.

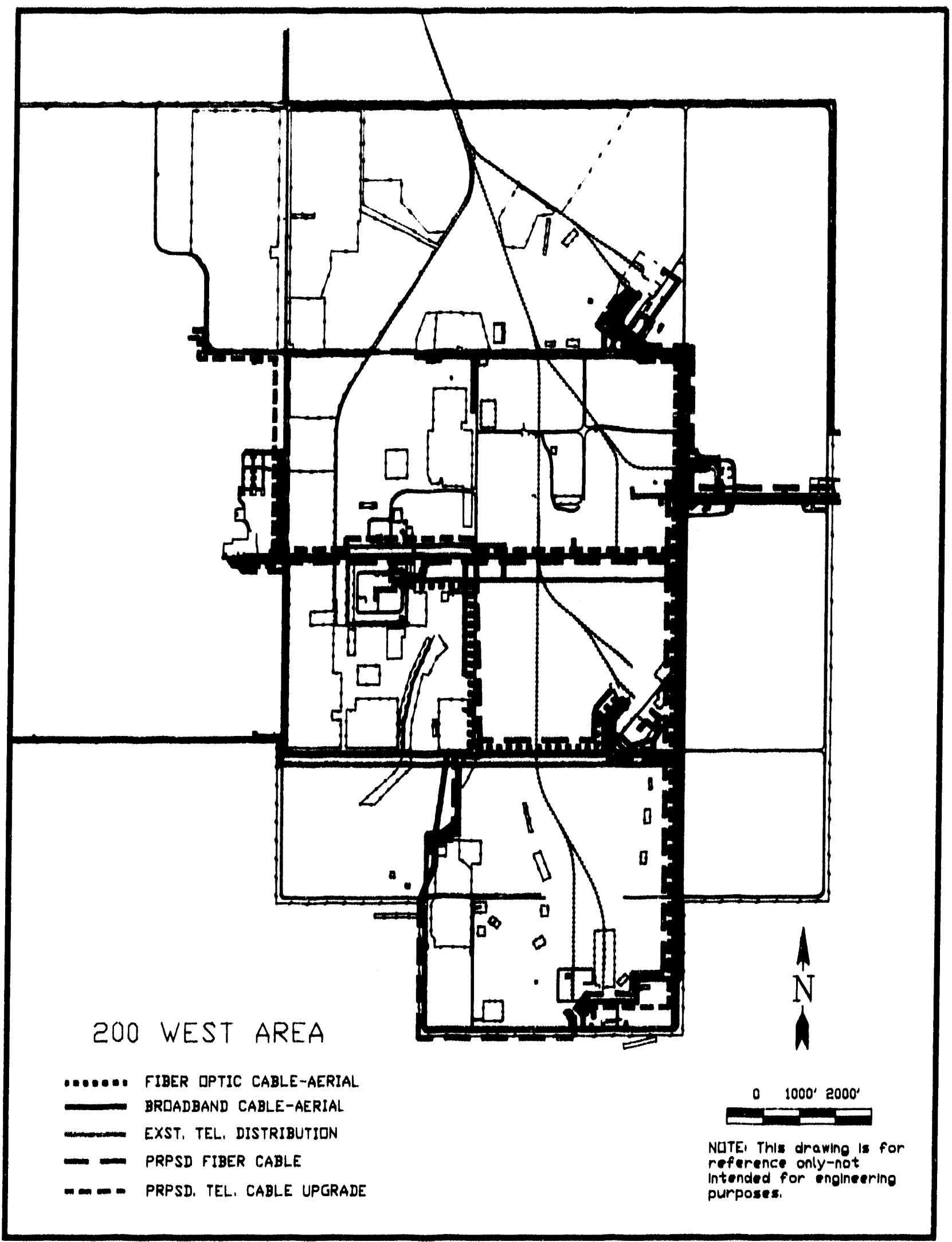

CADFILEI WHC\200W 
Figure 2-15. Existing and Planned Electrical Power Distribution in the 200 East Area.

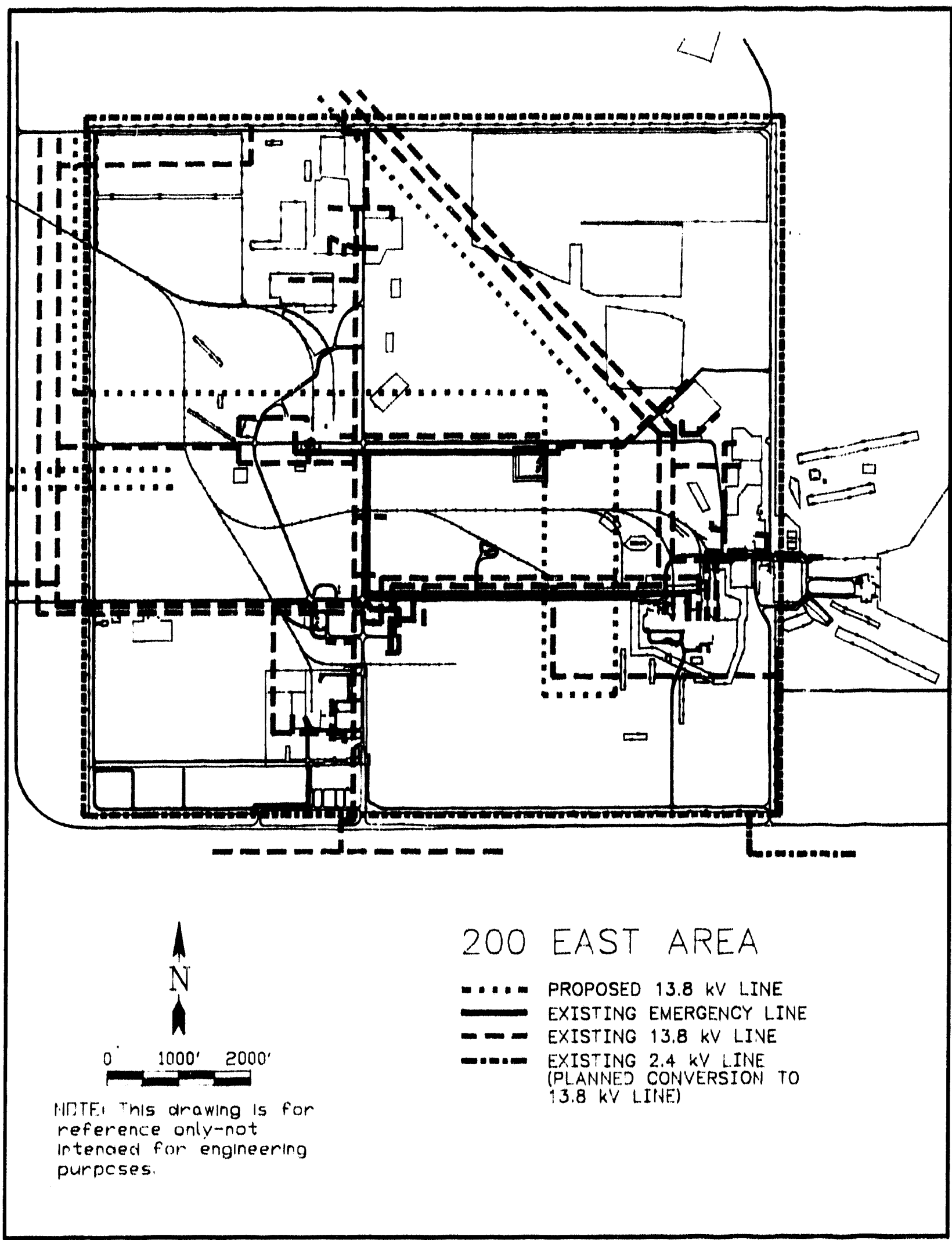

CADFILE ' W'HC DCOE 
Figure 2-16. Existing and Planned Electrical Power Distribution in the 200 West Area.

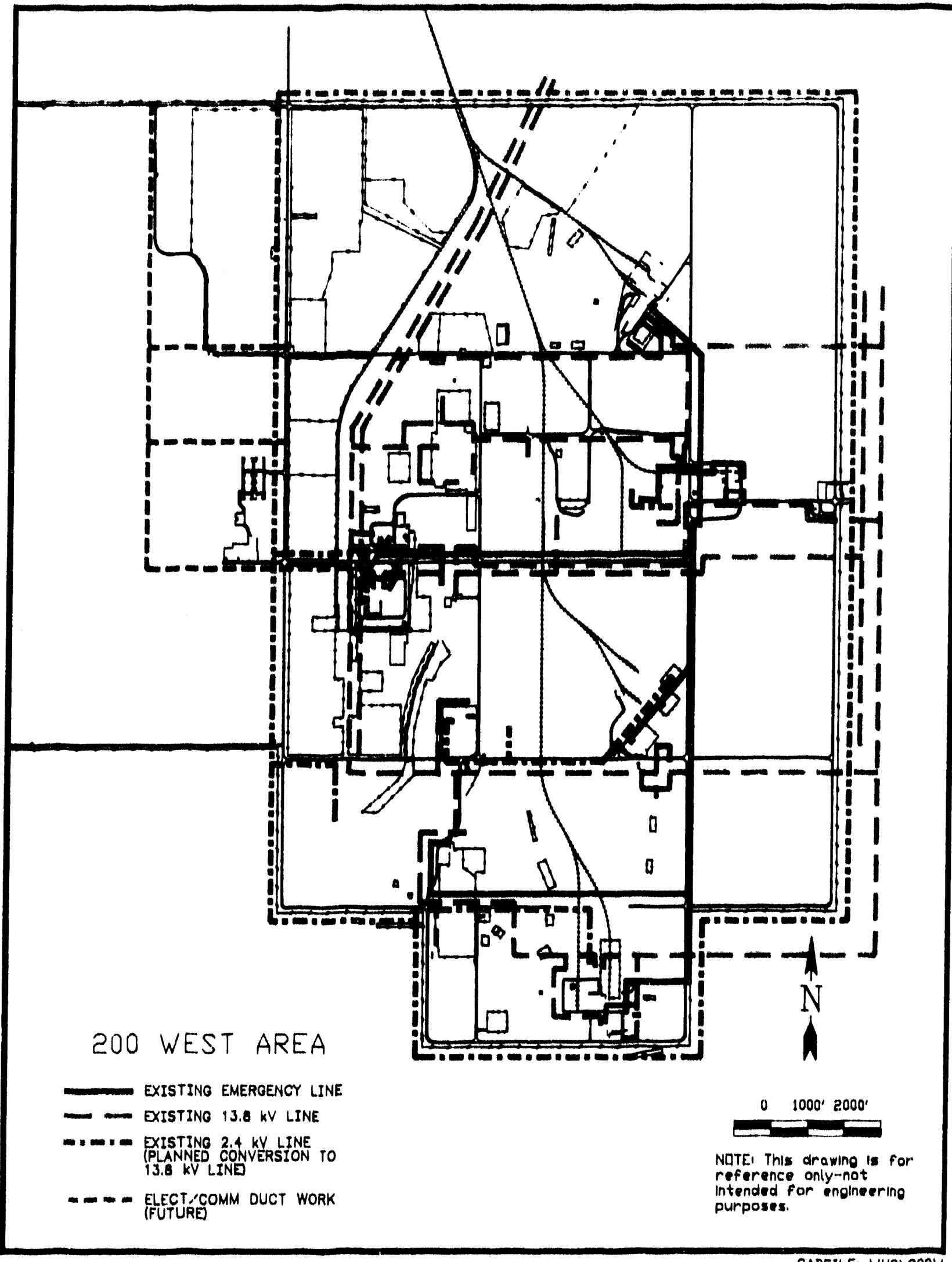

CADFILEI WHC $\backslash 200 W$ 
Several alternatives for meeting this need are currently being considered. They include upgrading the existing power plants, replacing the two existing plants with a single new facility which could be either government or privately owned/operated, using distributed package boilers, or a combination of package bollers and alternative energy sources such as electricity, propane or natural gas, and diesel generators.

Figure 2-17 shows existing steam distribution in the 200 East and 200 West Areas. If a centralized approach is selected for the future, Figure 2-18 shows the anticipated distribution. There is no planned expansion for steam distribution in the 200 West Area. Steam distribution in the corridor will parallel the new roads (see Figure 2-10 for conceptual road plans).

2.3.3.2.5 Sewer. Sanitary sewer effluents in the 200 Areas have been managed exclusively through the use of septic tanks and subsurface soll absorption systems since 1943. There are approximately 44 individual septic tanks and drainfields currently serving tile 200 Areas' facilities. Holding tanks are used for some small flow generation areas in lieu of septic tank systems. Some systems have failed and require regular pumping. This must continue until approvals can be obtained for replacing the falled septic systems.

A project proposal is being considered to develop a centralized collection, treatment, and disposal facility to handle the 200 Area sanitary waste. This is because of changing environmental regulations and growing concerns about existing systems' ability to handle current and projected needs derived from anticipated construction of new facilities and the attendant increase in personnel.

Figure 2-19 shows a conceptual collection system in each of the 200 East and 200 West Areas. The disposal process has not yet been chosen and the location of disposal facilities and collection system routes has not gone through the formal site selection process. Sanitary waste collection lines in the 200 Area Corridor would parallel the new roads.

2.3.3.2.6 Utilities Summary. The 200 Areas' infrastructure is approaching 50-years old. It will continue to be required throughout the foreseeable future. Significant portions of each infrastructure system wili need to be replaced or upgraded in the future.

Generally, line item projects include provision of necessary links to existing infrastructure. However, when several projects are foreseen in the same general location, it may make good financial sense to provide the infrastructure as part of a single project. This was done for the HCWC described in Section 4.1.3. This approach should al so be considered for the proposed Tank Waste Remediation System Complex (Section 4.1.2).

2.3.3.3 Emergency Services. This section identifies emergency services serving the 200 Areas. Emergency services include fire and medical services. 
Figure 2-17. Existing and $P 1$ anned Steam Distribution in the 200 East Area.

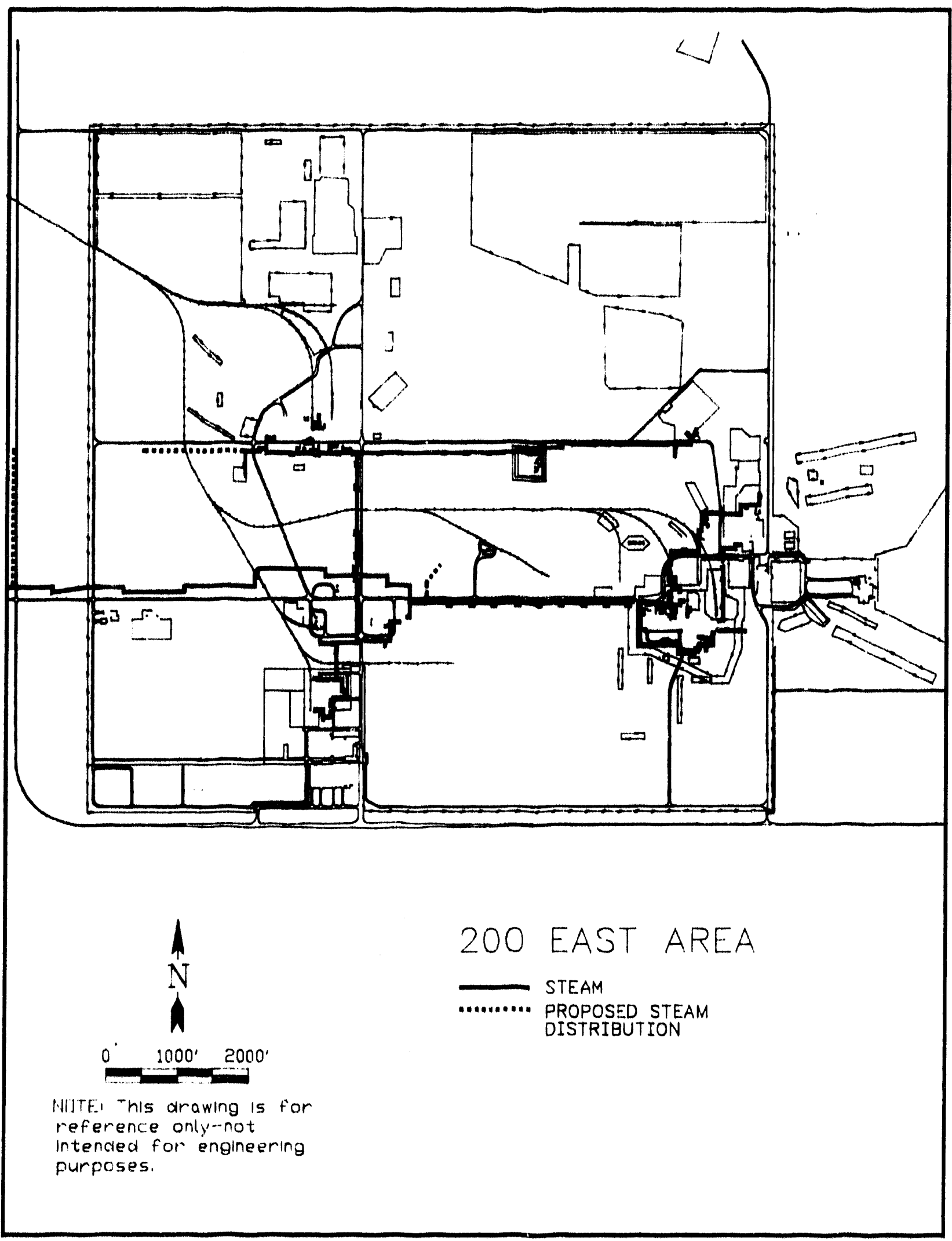


Figure 2-18. Existing and Planned Steam Distribution in the 200 West Area.

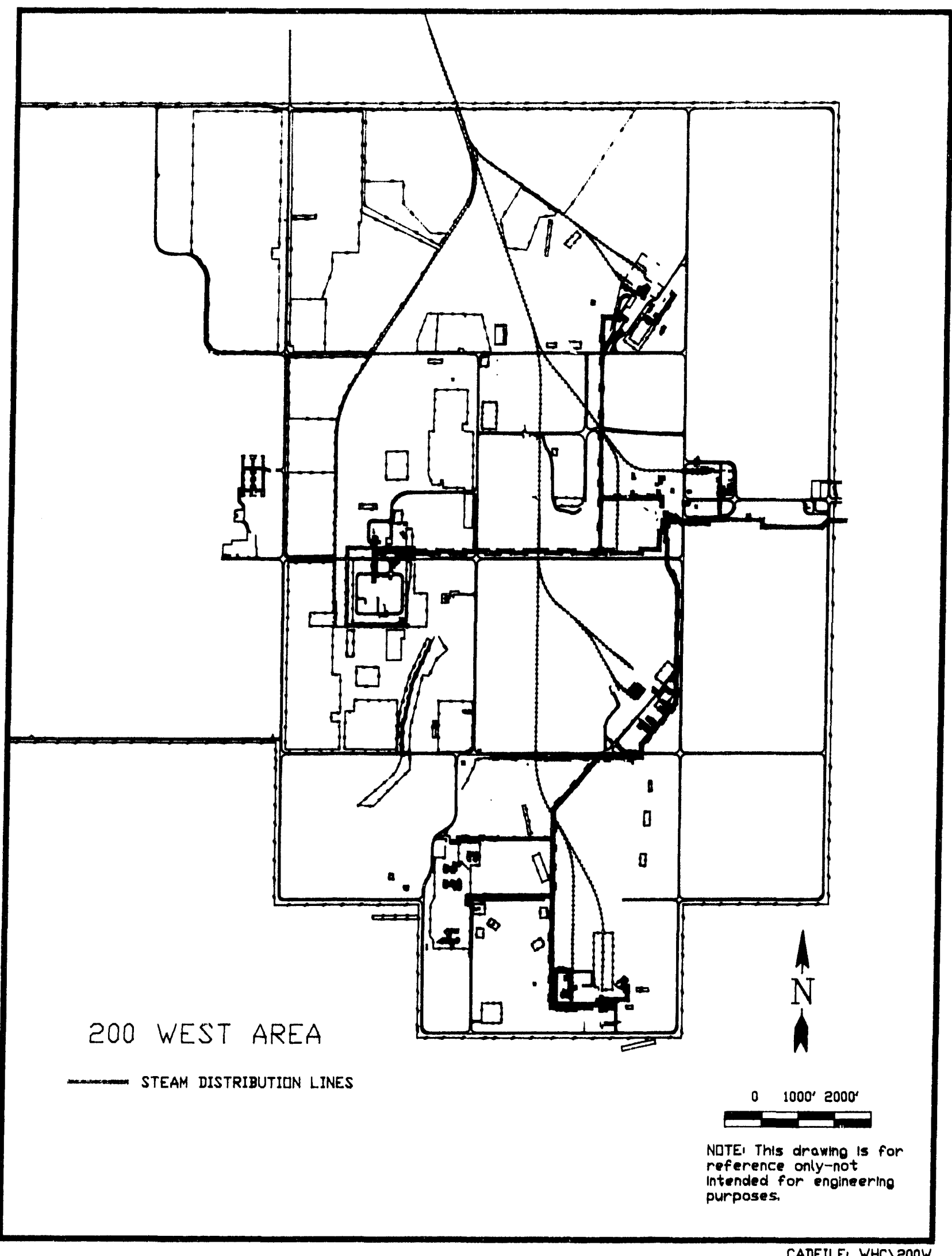


DOE/RL $-92-29$

Figure 2-19. Proposed 200 Areas Sanitary Waste Collection System.

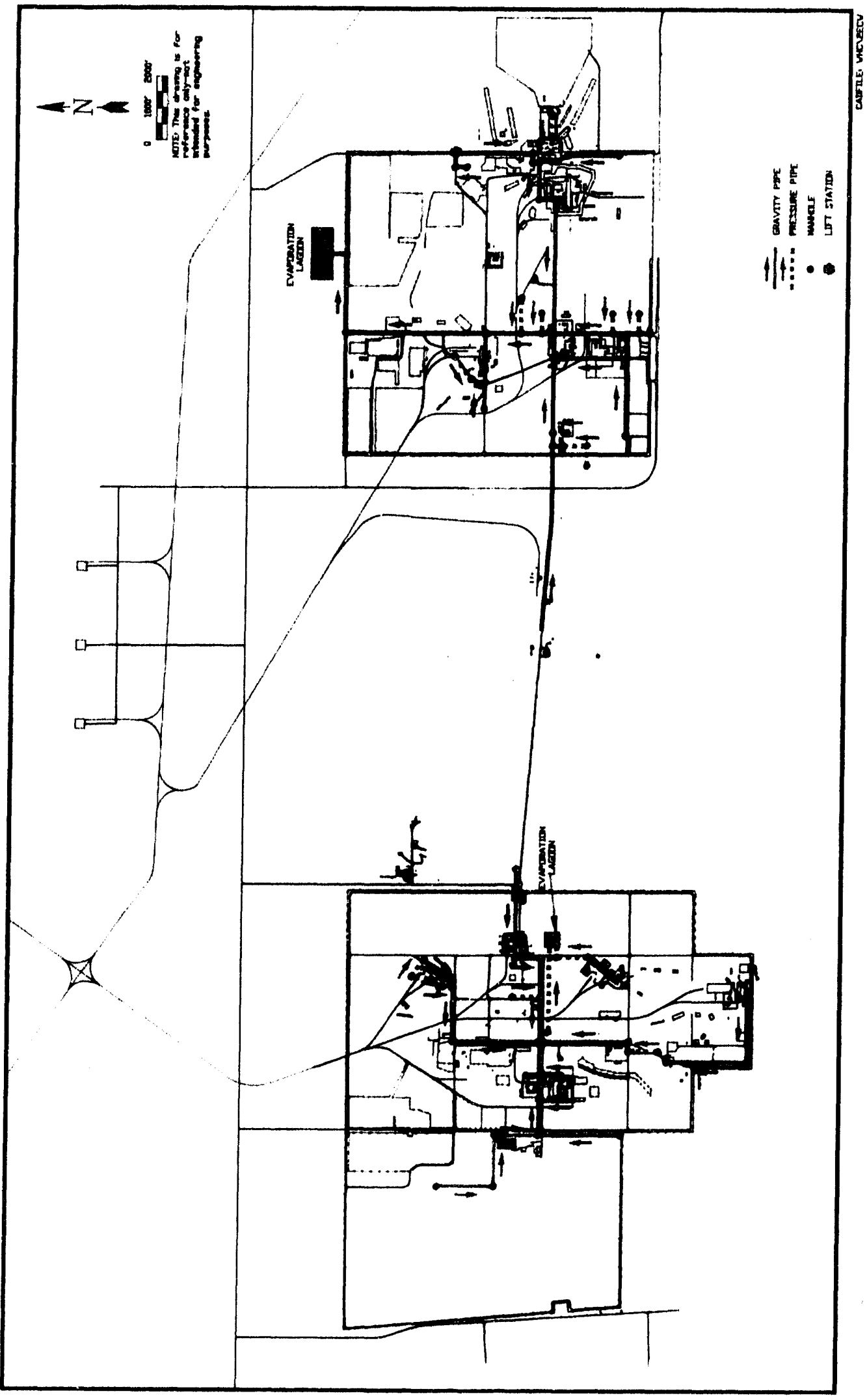


2.3.3.3.1 Fire. The 200 Area fire station provides primary pumper suppression response; ambulance operations, staffed by Hanford Fire emergency medical technicians and paramedics; and special rescue support to all 200 and 600 Area facilities and range lands. The fire station also provides secondary backup pumper response on all fire alarms in the 100 and 600 Areas, as well as backup ambulance support to the 100 and 600 Areas. Mutual aid responses and a Hazardous Materials Incident response team also reside at this station. A fire prevention program that includes operational control, inspection and testing of fire alarm and suppression systems, self contained breathing apparatus maintenance, building tours and inspections, and pre-fire planning for the Hanford Site are also managed and enforced from the 200 Area Fire Station.

The 200 Area fire station was constructed in 1965. An assessment of the fire station has revealed some physical and space deficiencies. Project L-094 has been identified to correct these deficiencies. This project will modify the Headquarters Administration Section into sleeping quarters and relocate the administrative personnel to a new 300 Area Headquarters Fire Station. The additional sleeping space will provide adequate room for the personnel located at the 100 Area Fire Station. The 100 Area Fire Station will be closed in FY 1997 and the 200 Area Fire Station will provide all emergency fire and medical services to all government owned property north of the Wye Barricade. Other upgrades being provided by Project L-094 consist of expanding the kitchen and rest room facilities, correcting electrical 1 ife safety and HVAC deficiencies, providing locker room space and disinfection space, removing asbestos, making miscellaneous repairs and replacements, and constructing an additional 2,500 square foot bay to house additional apparatus. This project will ensure that the 200 Area fire station will meet current code and standard requirements and the long-term needs of the Hanford Site.

2.3.3.3.2 Medical Services. Medical services are provided by the Hanford Environmental Health Foundation (HEHF) to provide basic occupational health care for the Hanford Work Force. Services are available 24 hours a day, seven days a week.

Nursing aid stations are located in the 2719EA Building in the 200 East Area and the 2719WA Building in the 200 West Area. First aid and emergency services are provided at these facilities.

The nursing aid station (2719WA) in the 200 West Area was constructed in 1949. This is an inadequate facility that adversely affects delivery of services. An FY 1994 General Plant Project has been identified to replace 2719WA. The 200 East nursing aid station is assessed as good.

\subsubsection{Developable Lands}

Developable areas within the 200 Areas (Figure 2-20) are identified by minor, moderate, and major constraints. Developable areas with minor and moderate constraints will allow development at a relatively low cost. Areas with major constraints will require high development costs. 
DOE/RL-92-29

Figure 2-20. 200 Areas Developable Lands.

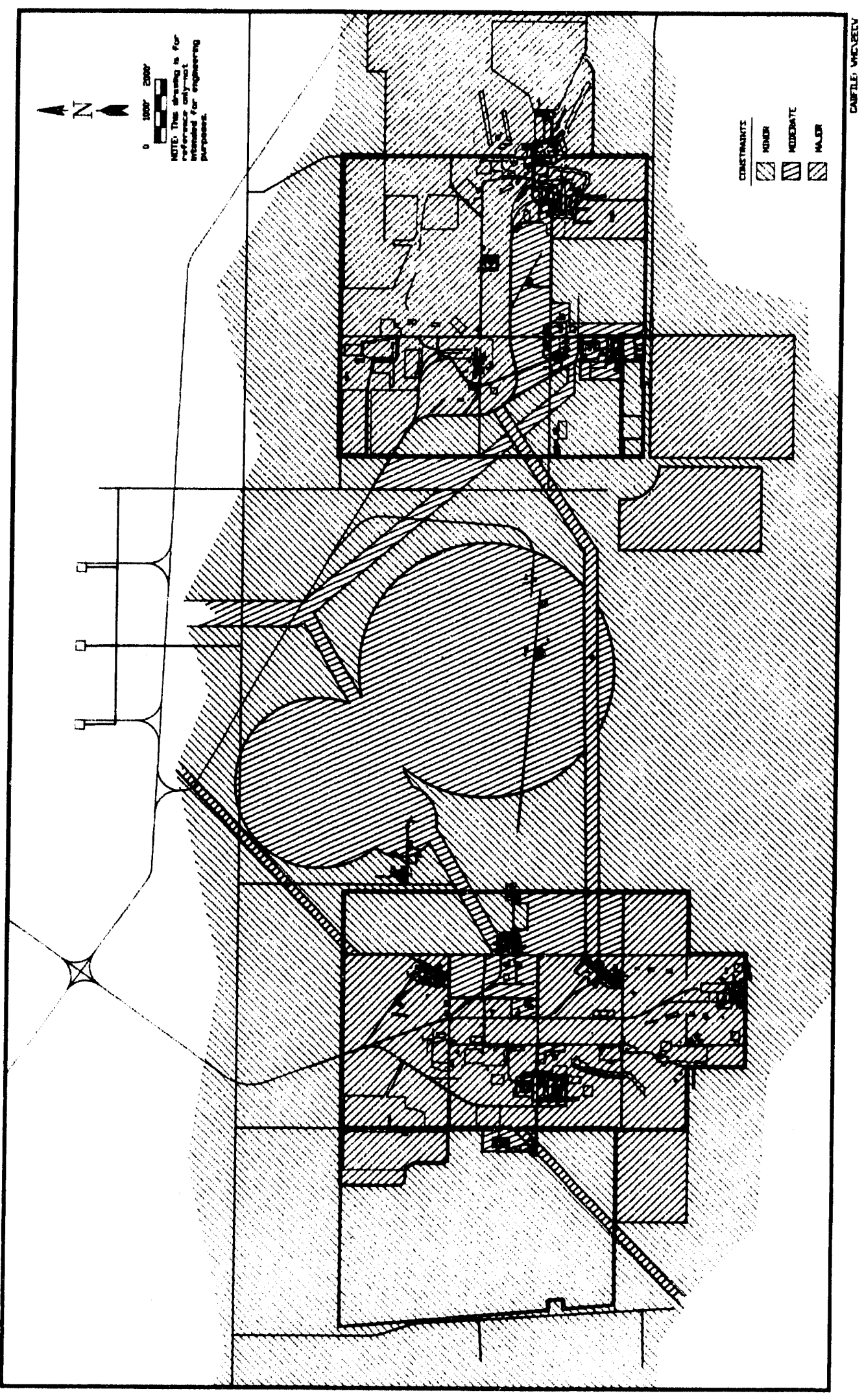


Minor: Developable areas with minor constraints are areas that are relatively open, flat, and primarily undisturbed. Few facilities are located in these areas and infrastructure development is minimal. Utilities can be provided to these areas by extending existing systems. In the 200 Areas, these lands are within operable units; therefore, development must be closely integrated with cleanup and restoration plans.

Moderate: Developable areas with moderate constraints are areas that have been developed or have specific requirements restricting certain types of activity. These areas usually contain a number of facilities and infrastructure systems. Extension of utilities to these areas can also be provided by extending or tapping into existing systems. These areas are also located within operable units and will need to be closely integrated with cleanup and restoration plans.

Major: Developable areas with major constraints are areas that are sensitive by statute (i.e., wetlands, areas significant to protected or endangered species, land with culturally historic value) or areas that would be very costiy to develop (i.e., previously used for reprocessing and waste operations, steep slopes). Many of these areas consist of waste sites, such as trenches, ponds, and burial grounds, and/or have a number of existing pipe runs and facilities on them. These areas may contain surface and/or subsurface contamination. After the year 2018, contaminated lands could be redeveloped depending on the level of cleanup, and assuming the 1 and is released for new uses.

Design and construction of all future projects proposed to be located in the three areas (minor, moderate, and major) must be coordinated closely with the appropriate operabie unit manager(s) to ensure compliance with environmental requirements and to minimize construction, remediation, and operating costs. The Westinghouse Hanford Company Environmental Engineering group should be contacted before any activities within an operable unit are planned.

\subsection{SAFEGUARDS AND SECURITY}

\subsubsection{Physical Security}

The Safeguards and Security Program has three main operating objectives: (1) ensure the physical protection, control, and accountability of special nuclear material; (2) provide physical protection for operating facilities, sensitive property, and equipment; and (3) protect against the release of classified information to unauthorized personnel.

The 200 Areas are within the Hanford Site controlled area. Public access to these areas is restricted. As Figure 2-21 shows, a11 of the 200 East and 200 West Areas are currently within property protection areas. Portions of the 202A Facility and the Patrol Operations Center in the 2721E Building are designated as limited area islands within the 200 East property protection areas. 
DOE/RL-92-29

Figure 2-21. Existing 200 Areas Physical Security.

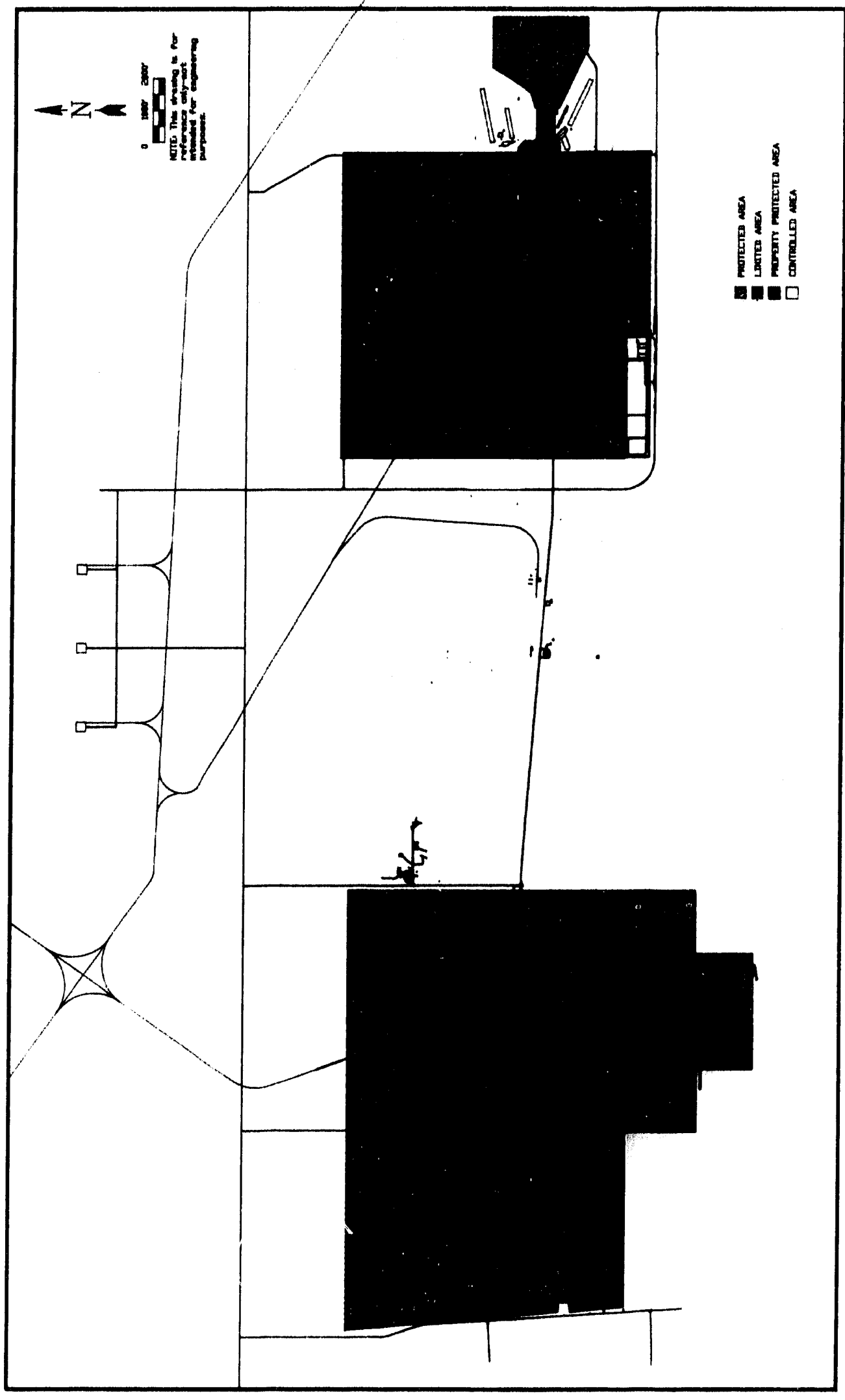


The PFP is a protected area within the 200 West property protection areas. The 200 Area Corridor is part of the overall Hanford Site controlled area and does not inslude any designated security areas.

The continued protection of DOE facilities, materials, and information will remain the goal of the Safeguards and Security Program. Security planning will be driven by the shifting emphasis away from defense nuclear materials production toward environmental restoration and waste management.

To support the change in mission, the RL has identified five key safeguards and security initiatives to guide future Hanford Site security planning efforts. These initiatives are as follows:

- Reduce the number of protected areas on the Hanford Site via consolidation and/or transfer of special nuclear material.

- Consolidate and eliminate locations of nonprotected area special nuclear material on a cost versus benefit basis consistent with programmatic mission requirements.

- Consolidate and eliminate locations of classified matter on a cost versus benefit basis consistent with programmatic mission requirements.

- Reduce the need for security clearances to a level consistent with mission and program requirements.

- Apply new technology to safeguards and security applications on a cost versus benefit basis consistent with mission requirements.

These initiatives are designed to reduce protection program costs while maintaining required protection. Plans for implementing the first initiative call for reducing the protected areas to one. The single protected area will be the PFP in the 200 West Area. The PFP is projected for continued storage of special nuclear material for the foreseeable future.

The other initiatives, combined with the continuing evolution of the Hanford Site mission, will result in significant reductions in classified matter onsite and the number of personnel security clearances required. Currently, all 200 Areas' classified matter is either within the PFP protected area or the Patrol Operations Center limited area island. These effects, in turn, will result in a continuing reduction in security zones and physical security barriers. At the same time, emphasis on providing increased levels of security for waste tanks and tank farm operations can be expected. Future security functions can be expected to be provided through automation.

Future 200 Areas' physical security will consist of two activities. An industrial security level of protection will be provided for inactive facilities. At the same time, appropriate security measures will be maintained for the few remaining special nuclear material and classified information security interests. 


\subsubsection{Significant Nuclear Inventories}

This section identifies facilities in the 200 Areas that have significant nuclear inventories. The majority of these facilities are involved in the processing and storage of radioactive materials. These facilities have the potential for onsite and offsite impacts to large numbers of people and the environment.

In the 200 East Area, facilities with significant nuclear inventories consist of active and inactive waste sites, SST and DST farms, and individual buildings. Table 2-7 identifies these facilities and their nuclear inventories.

In the 200 West Area, facilities with significant nuclear inventories consist of inactive waste sites, SST and DST farms, and individual buildings. Table 2-8 identifies these facilities and their nuclear inventories.

Currently, no buildings in the 200 Area Corridor are designated as having significant nuclear inventories.

\subsection{ENVIRONMENTAL ACTIVITIES}

This section briefly discusses existing and future environmental activities in the 200 Areas. These environmental activities will focus on the cleanup and management of hazardous wastes.

\subsubsection{Hanford Federal Facility Agreement and Consent Order}

The EPA, on November 3, 1989, 1isted the 200 East Area and 200 West Area for inclusion on the National Priorities List (NPL) (EPA 1989) under CERCLA. This action is being incorporated into the continuing environmental restoration efforts at the Hanford Site. These efforts are being addressed through the Tri-Party Agreement (Ecology et al. 1990) that was negotiated and signed in May 1989 by the Ecology, the EPA, and the DOE.

Because of the magnitude of the work required by the Tri-Party Agreement, a uniform streamlined process was established to (1) meet statutory requirements, (2) integrate CERCLA remedial investigation/feasibility study (RI/FS) and RCRA past-practice RCRA facility investigation/corrective measures study (RFI/CMS) guidance, (3) satisfy the Tri-Party Agreement, and (4) ensure the protection of human health and welfare and the environment at the Hanford Site.

\subsubsection{Operable Units}

The 200 Areas' NPL site is divided into eight waste area groups that share similar characteristics and are located in the same general area. These waste area groups are further subdivided into 37 operable units, with 19 in the 200 East Area, 17 in the 200 West Area, and 1 in the 200 Area Corridor (see Figures 2-22, 2-23, and 2-24). Six isolated operable units located within the 600 Area are also associated with the 200 Areas' NPL. 
Table 2-7. 200 East Area Significant Nuclear Inventories.

\begin{tabular}{|c|c|c|}
\hline $\begin{array}{l}\text { Building } \\
\text { number }\end{array}$ & Building name & $\begin{array}{c}\text { Nuclear } \\
\text { inventory* }\end{array}$ \\
\hline $221 B$ & Separations Building & $M C i, g$ \\
\hline $225 \mathrm{~B}$ & Waste Encapsulation and Storage Facility & $M C i,<\mu \mathrm{g}$ \\
\hline $218 \mathrm{E}$ & Inactive Burial Grounds & $\mathrm{MCl}, \mathrm{kg}$ \\
\hline $218 \mathrm{E \& W}$ & $\begin{array}{l}\text { Active Burial Grounds (East and West } \\
\text { combined) }\end{array}$ & $\mathrm{MCi}, \mathrm{kg}$ \\
\hline \multirow[t]{2}{*}{$243 \mathrm{G}$} & Grout Facility (Future) & $\mathrm{MCi}, \mathrm{kg}$ \\
\hline & $\begin{array}{l}\text { Plutonium-Uranium Extraction Raflroad } \\
\text { Tunnel }\end{array}$ & $M C i, \mathrm{~kg}$ \\
\hline $241 \mathrm{~A}$ & Single-Shell Tank Farm & $\mathrm{MCi}, \mathrm{kg}$ \\
\hline $241 \mathrm{AN}$ & Double-Shell Tank Farm & $\mathrm{MCi}, \mathrm{kg}$ \\
\hline $241 \mathrm{AW}$ & Double-Shall Tank Farm & $\mathrm{MCi}, \mathrm{kg}$ \\
\hline $241 \mathrm{AX}$ & Single-Shell Tank Farm & $\mathrm{MCi}, \mathrm{kg}$ \\
\hline 241 AY & Aging Waste Tank Farm & $\mathrm{MCi}, \mathrm{kg}$ \\
\hline $241 \mathrm{AZ}$ & Aging Waste Tank Farm & $\mathrm{MCi}, \mathrm{kg}$ \\
\hline $241 B$ & Single-Shell Tank Farm & $\mathrm{MCl}, \quad \mathrm{Qg}$ \\
\hline $241 \mathrm{BX}$ & Single-Shell Tank Farm & $\mathrm{MCi}, \mathrm{kg}$ \\
\hline $241 \mathrm{BY}$ & Single-Shell Tank Farm & $\mathrm{MCi}, \mathrm{kg}$ \\
\hline $241 C$ & Single-Shell Tank Farm & $\mathrm{MCi}, \mathrm{kg}$ \\
\hline $216 E$ & Active Cribs/Ponds/Trenches & $\mathrm{kCi}, \mathrm{kg}$ \\
\hline $242 \mathrm{~A}$ & Evaporator & $\mathrm{kCi}, \mathrm{g}$ \\
\hline 244 AR & Vault & $\mathrm{kCi}, \mathrm{g}$ \\
\hline $202 A$ & $\begin{array}{l}\text { Plutonium-Uranium Extraction Canyon } \\
\text { Building }\end{array}$ & $\mathrm{kCl}, \mathrm{kg}$ \\
\hline $241 \mathrm{AP}$ & Double-Shell Tank Farm & $\mathrm{kCi}, \mathrm{kg}$ \\
\hline
\end{tabular}

NOTE: 200 East Area Inactive Cribs/Ponds/Trenches--No Data.

$g=$ Grams of uranium and transuranic products.

$k C i=$ Kilocuries of fission and activation products.

$\mathrm{kg}=$ Kilograms of uranium and transuranic products.

$M C \dot{I}=$ Megacuries of fission and activation products.

$\mu \mathrm{g}=$ Micrograms of uranium and transuranic products.

* = Nuclear inventory values are order-of-magnitude. 
Table 2-8. 200 West Area Significant Nuclear Inventories.

\begin{tabular}{|c|c|c|}
\hline $\begin{array}{l}\text { Butlding } \\
\text { number }\end{array}$ & Bullding name & $\begin{array}{c}\text { Nuclear } \\
\text { inventory* }\end{array}$ \\
\hline $218 W$ & Inactive Burial Grounds & $\mathrm{MCl}, \mathrm{kg}$ \\
\hline $241 S$ & Single-Shell Tank Farm & $\mathrm{MCl}, \mathrm{kg}$ \\
\hline $2415 x$ & Single-Shell Tank Farm & $\mathrm{MCi}, \mathrm{kg}$ \\
\hline $241 S Y$ & Double-Shell Tank Farm & $\mathrm{MCi}, \mathrm{kg}$ \\
\hline $241 T$ & Single-Shell Tank Farm & $\mathrm{MCl}, \mathrm{kg}$ \\
\hline $241 \mathrm{TX}$ & Single-Shell Tank Farm & $\mathrm{MCl}, \mathrm{kg}$ \\
\hline $241 \mathrm{TY}$ & Single-Shell Tank Farm & $\mathrm{MCl}, \mathrm{kg}$ \\
\hline $241 U$ & Single-Shell Tank Farm & $\mathrm{MCi}, \mathrm{kg}$ \\
\hline $285 W$ & Hanford Central Waste Complex & $\mathrm{kCl}, \mathrm{g}$ \\
\hline $202 S$ & Reduction-0xidation Plant & $\mathrm{kCi}, \mathrm{kg}$ \\
\hline $236 Z$ & Plutonium Reclaim & $\mathrm{kg}$ \\
\hline $2736 Z$ & Plutonium Storage & $\mathrm{kg}$ \\
\hline 2763 ZB & Plutonium Storage & $\mathrm{kg}$ \\
\hline $221 \mathrm{~T}$ & Decon Fac./Rx Core Storage & $\mathrm{kCi}, \mathrm{kg}$ \\
\hline $221 \mathrm{U}$ & U Plant Complex & $\mathrm{kCl}$ \\
\hline
\end{tabular}

NOTE: 200 West Area Inactive Cribs/Ponds/Trenches--No Data.

$g=$ Grams of uranium and transuranic products.

$\mathrm{kCi}=\mathrm{Kilocuries}$ of fission and activation products.

$\mathrm{kg}=$ Kilograms of uranium and transuranic products.

MCi = Megacuries of fission and activation products.

* Nuclear inventory values are order-of-magnitude.

Operable unit cleanup responses have been prioritized based on an initial assessment of potential risk to the public. The 20 highest priority operable units have been ranked individually and scheduled for investigation; the remaining operable units have been prioritized in groups (B, $C$, and $D)$. Characterization and development of cleanup plans for each operable unit will depend on its priority witlin its own grouping. Actual cleanup will begin when cleanup $p$ lans have been reviewed by the public and regulatory permits and approvals have been received.

Tables 2-9 and 2-10 identify each of the 200 East and 200 West operable units by priority, when characterization and development of cleanup plans should be completed, when actual cleanup should begin, and by aggregate area, which is discussed in Section 2.5.4. 


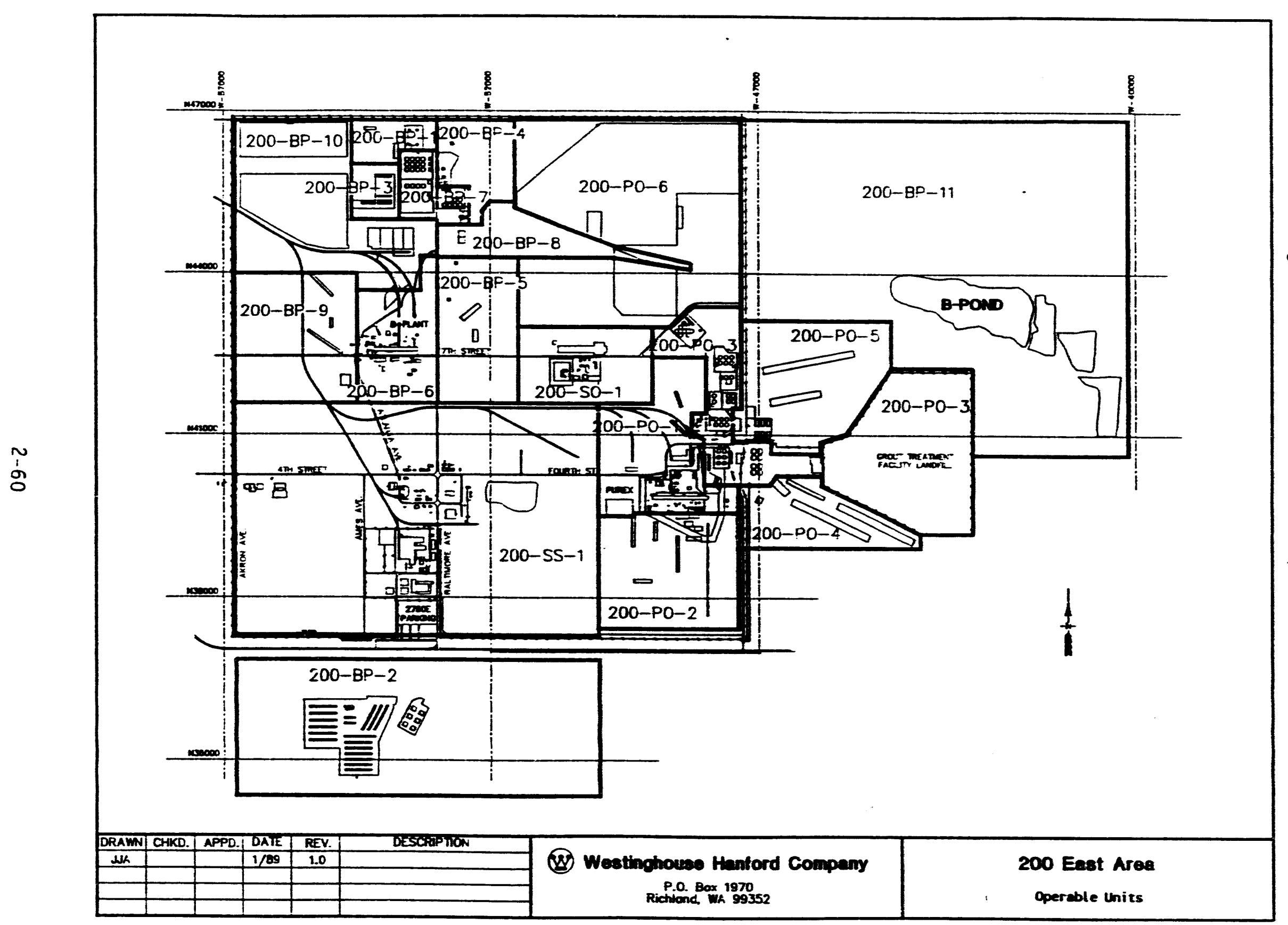

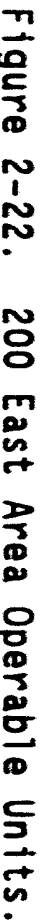


Figure 2-23. 200 West Area Operable Units.

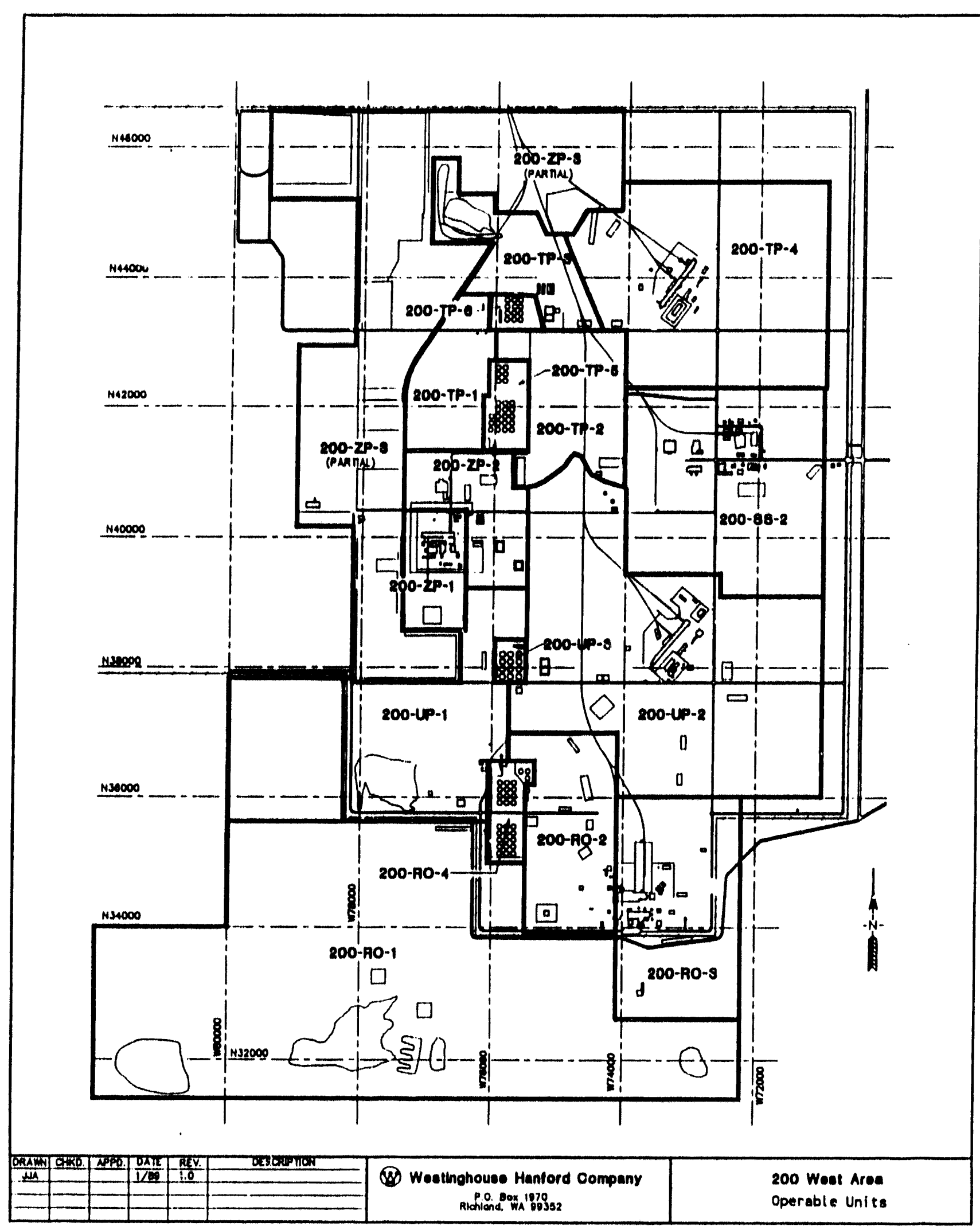


Figure 2-24. 600 Area Operable Units.

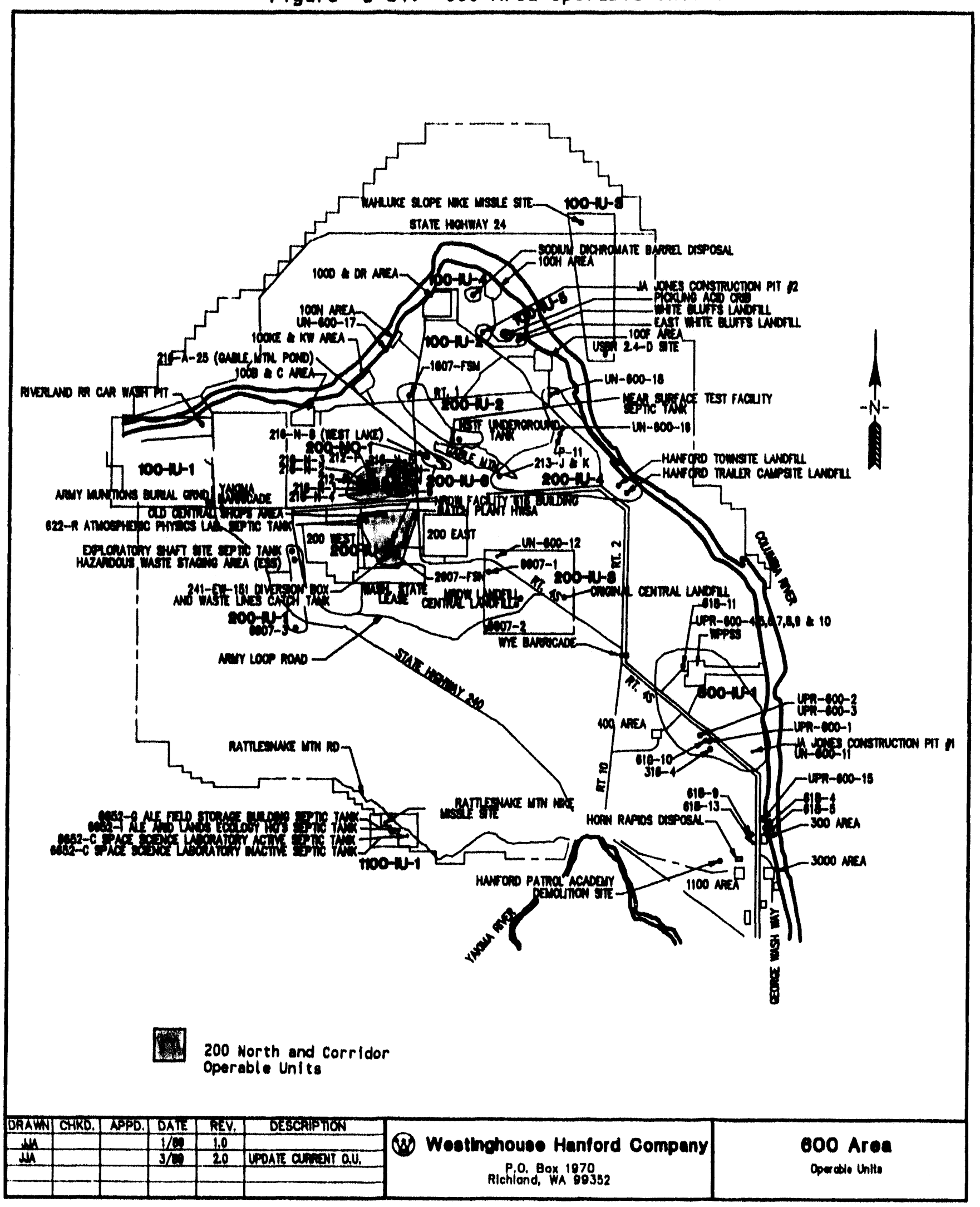


Table 2-9. 200 East Area Operable Units.

\begin{tabular}{|c|c|c|c|c|}
\hline $\begin{array}{c}200 \text { East Area } \\
\text { operable } \\
\text { units }\end{array}$ & Priority & $\begin{array}{c}\text { Completion of } \\
\text { characterization } \\
\text { and development } \\
\text { of cleanup }\end{array}$ & $\begin{array}{l}\text { Start of } \\
\text { actual } \\
\text { cleanup }\end{array}$ & $\begin{array}{c}\text { Aggregate } \\
\text { area }\end{array}$ \\
\hline 200-BP-1 & 3 & FY 1995 & FY 1996 & B Plant \\
\hline 200-BP-2 & B & FY 2000 & FY 2001 & B Plant \\
\hline $200-B P-3$ & C & FY 2004 & FY 2005 & B Plant \\
\hline $200-B P-4$ & 17 & FY 1998 & FY 1999 & B Plant \\
\hline $200-B P-5$ & 13 & FY 1998 & FY 1999 & B Plant \\
\hline $200-B P-6$ & C & FY 2004 & FY 2005 & B Plant \\
\hline *200-BP-7 & - & -- & -- & B Plant \\
\hline $200-B P-8$ & $C$ & FY 2004 & FY 2005 & B Plant \\
\hline $200-B P-9$ & $C$ & FY 2004 & FY 2005 & B Plant \\
\hline $200-B P-10$ & $C$ & FY 2004 & FY 2005 & B Plant \\
\hline 200-BP-11 & 18 & FY 1999 & FY 2000 & B Plant \\
\hline 200-P0-1 & B & FY 2000 & FY 2001 & PUREX Plant \\
\hline $200-P 0-2$ & 19 & FY 1999 & FY 2000 & PUREX Plant \\
\hline *200-PO-3 & -- & -- & -- & PUREX Plant \\
\hline $200-P 0-4$ & B & FY 2001 & FY 2002 & PUREX Plant \\
\hline $200-P 0-5$ & 20 & FY 1999 & FY 2000 & PUREX Plant \\
\hline $200-P 0-6$ & C & FY 2005 & FY 2006 & PUREX Plant \\
\hline 200-S0-1 & $B$ & FY 2001 & FY 2002 & Semi-Works \\
\hline 200-SS-1 & $\bar{D}$ & FY 2007 & FY 2008 & B Plant \\
\hline
\end{tabular}

FY = Fiscal year.

PUREX = Plutonium-Uranium Extraction.

*This operable unit contains single-shell tanks (SST) and is not prioritized with other operable units. Schedules for Resource Conservation and Recovery Act of 1976 facility investigation/corrective measures study work $p l a n s$ and subsequent characterization are being developed as part of the SST system closure/corrective action work plan. 
Table 2-10. 200 West Area Operable Units.

\begin{tabular}{|c|c|c|c|c|}
\hline $\begin{array}{c}200 \text { West Area } \\
\text { operable } \\
\text { units }\end{array}$ & Priority & $\begin{array}{c}\text { Completion of } \\
\text { characterization } \\
\text { and development } \\
\text { of cleanup }\end{array}$ & $\begin{array}{l}\text { Start of } \\
\text { actual } \\
\text { c?eanup }\end{array}$ & $\begin{array}{c}\text { Aggregate } \\
\text { area }\end{array}$ \\
\hline 200-RO-1 & $C$ & FY 2005 & FY 2006 & S Plant \\
\hline $200-R 0-2$ & $C$ & FY 2005 & FY 2006 & S Plant \\
\hline $200-R 0-3$ & $C$ & FY 2005 & FY 2006 & S Plant \\
\hline$* 200-R 0-4$ & -- & -- & -- & S Plant \\
\hline $200-S S-2$ & $D$ & FY 2007 & FY 2008 & $T$ Plant \\
\hline $200-T P-1$ & B & FY 2001 & FY 2002 & $T$ Plant \\
\hline $200-T P-2$ & B & FY 2001 & FY 2002 & $\mathrm{~T}$ Plant \\
\hline $200-T P-3$ & $C$ & FY 2005 & FY 2006 & $\mathrm{~T}$ Plant \\
\hline $200-T P-4$ & B & FY 2001 & FY 2002 & $\mathrm{~T}$ Plant \\
\hline$\star 200-T P-5$ & -- & -- & -- & $\mathrm{T} \mathrm{Pl}$ ant \\
\hline$* 200-T P-6$ & - & -- & -- & $\mathrm{T}$ Plant \\
\hline 200-UP-1 & C & FY 2005 & FY 2006 & U Plant \\
\hline 200-UP-2 & 11 & FY 1997 & FY 1998 & U Plant \\
\hline$\star 200-U P-3$ & -- & -- & -- & U Plant \\
\hline $200-Z P-1$ & 15 & FY 1998 & FY 1999 & PFP \\
\hline $200-Z P-2$ & B & FY 2002 & FY 2003 & PFP \\
\hline $200-Z P-3$ & $C$ & FY 2006 & FY 2007 & PFP \\
\hline
\end{tabular}

PFP = Plutonium Finishing Plant.

*This operable unit contains single-shell tanks (SST) and is not prioritized with other operable units. Schedules for Resource Conservation and Recovery Act of 1976 facility investigation/corrective measures study work plans and subsequent characterization are being developed as part of the SST system closure/corrective action work plan. 
In the 200 Area Corridor, Operable Unit 200-IU-5 (Figure 2-24) is priority D. Characterization and development of cleanup plans should be completed sometime in FY 2007 depending on its priority within the D grouping. Actual cleanup could begin sometime in FY 2008. Completion will depend on how the work is done.

An RI/FS or RFI/CMS work plan will be completed for each operable unit. A schedule for implementation of the RI/FS process is based on each operable unit as agreed to in the Tri-Party Agreement (Ecology et al. 1990). The RI/FS determines the nature and extent of the threat presented by releases of hazardous substances from the operable units and to evaluate proposed remedies for such releases. The goal of the RI/FS is to allow for the selection and subsequent implementation of a cost-effective remedial alternative that ensures the protection of public health and the environment.

\subsubsection{Expedited Response Actions}

During the early plutonium recovery processes at the Hanford Site, radioactively contaminated acidic aqueous wastes and organic liquids were discharged to the soil column at three disposal sites (216-Z-1A Tile Field, the 216-Z-18 (rib, and the 216-Z-9 Trench) in the 200 West Area. As a result, a portion of the underlying groundwater is contaminated with carbon tetrachloride, a suspected carcinogen, several orders of magnitude above the maximum contaminant level accepted for a drinking water supply.

In January 1992, the EPA and Ecology authorized the DOE to begin cleanup of the carbon tetrachloride in the unsaturated soils through an expedited response action. An expedited response action is a provision in the CERCLA that allows for accelerated cleanup activities. The goal of this action is to mitigate the spread of the carbon tetrachloride from the disposal sites to the groundwater in the 200 West Area by removing carbon tetrachloride from the unsaturated soils.

\subsubsection{Aggregate Area Management Study Reports}

The RL, Ecology, and the EPA have negotiated a change package (M-12-90-4) to the Tri-Party Agreement. The regulatory agencies and DOE streami ined the RI/FS process. The first phase of this new approach for the 200 Areas is to implement source aggregate area management study reports (AAMSR) based on the eight waste area groups discussed and two groundwater AAMSRs, one for the 200 East Area and one for the 200 West Area. Figures 2-25 and 2-26 identify the aggregate areas within the 200 Areas. Two groundwater aggregate areas (not shown) encompass the entire 200 East and 200 West Areas. 


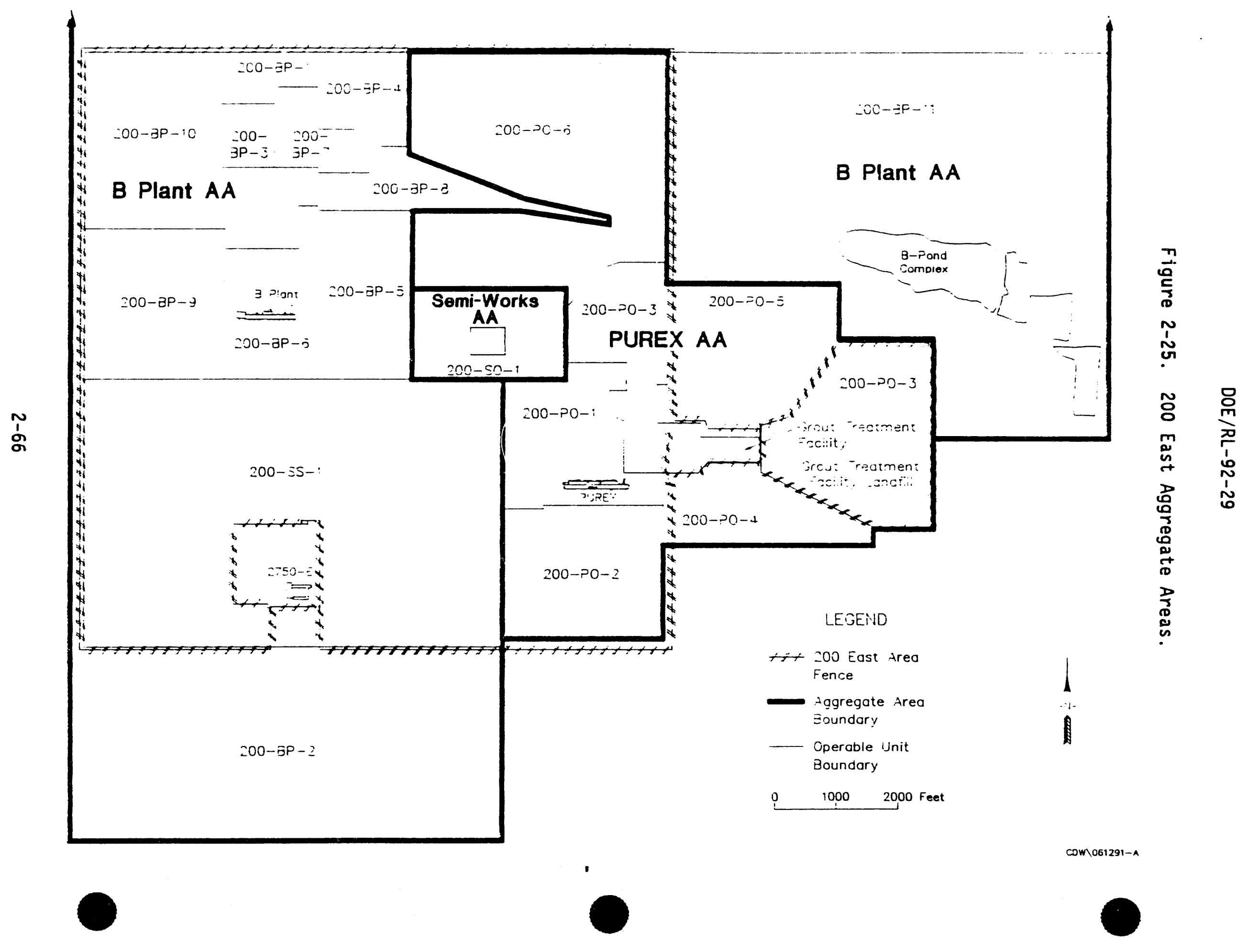




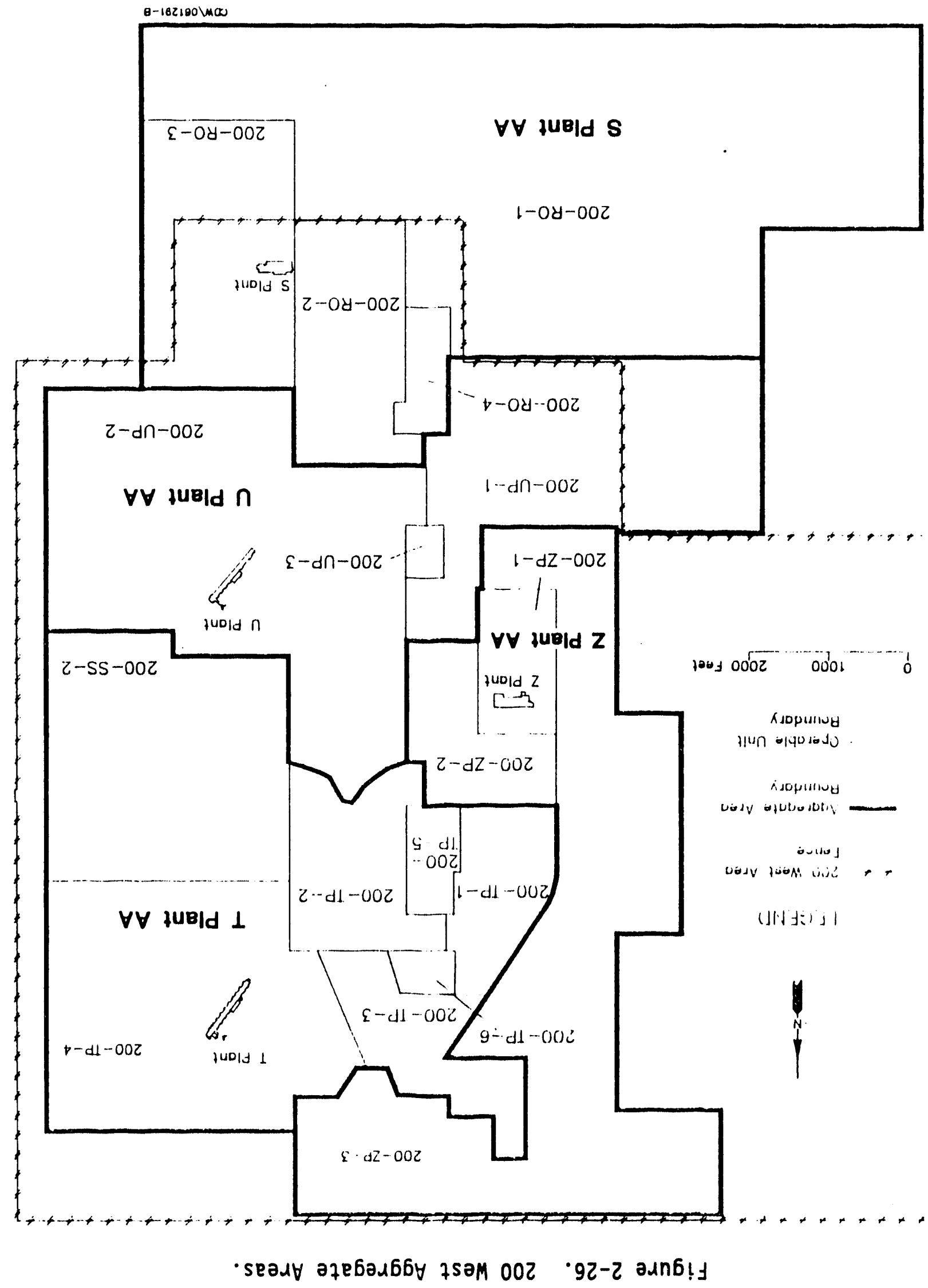


The primary purpose of each AAMSR is to search, compile, and evaluate existing data such that contaminants of concern can be identified, the scope of future characterization efforts can be determined, and a conceptual model of the aggregate area can be developed. Each AAMSR will result in management recommendations that include (1) the need for expedited, interim, or limited actions, (2) definition and prioritization of operable units, (3) prioritization of work plan activities, (4) integration of RCRA treatment, storage, or disposal closure activities, (5) conduct of field characterization activities, and (6) the need for treatability studies. Each AAMSR will determine whether existing information is sufficient to forego further characterization efforts and whether to proceed with a final risk assessment and feasibility study that would lead to a record of decision. The 10 AAMSRs are now in the M-27-00 series milestones in the Tri-Party Agreement. The results of the studies will be used to prioritize and implement characterization and remediation work for the 200 Areas.

\subsubsection{Environmental Permitting Activities}

Currently, 33 facilities in the 200 Areas have been identified as RCRA treatment, storage, or disposal facilities. These facilities operate or have operated with dangerous waste as specified in Washington (State)

Administrative Code (WAC) 173-303. The Ecology and EPA have been notified of the status of these facilities by the submission of Part $A$ permit applications. Permits for 14 of these facilities will be sought for continued dangerous waste operations. Part B permit applications for each of these facilities will be or have been submitted to the Ecology and/or the EPA for approval. These permit application submittals have been scheduled as part of the Tri-Party Agreement. These facilities are identified in Table 2-11.

The remaining facilities are no longer operating for treatment, storage, or disposal of dangerous wastes. These facilities will be closed in accordance with WAC 173-303. Closure plans will be submitted to Ecology and EPA for approval as scheduled in the Tri-Party Agreement (Ecology et al. 1990).

The following are brief descriptions of the permits identified in Table 2-11.

Part A Permit Application--The part of the consolidated permit application that a RCRA permit applicant must complete to qualify for interim status for each treatment, storage, or disposal waste management unit dealing with dangerous waste. This application also will be used for consideration for a final permit. The Part $A$ consists of a general information form (Form 1) and a hazardous waste application form (Form 3). Currentily at the Hanford Site, there is one Form 1 and 62 individual Form 3 's.

Part B Permit Application--The part of the application that a RCRA permit applicant must complete to be issued a final permit. Each individual treatment, storage, or disposal waste management unit that includes operations that treat, store, and/or dispose of dangerous waste will require a permit application to be submitted to the Ecology and the EPA. 
Table 2-11. 200 Area Resource Conservation and Recovery Act Permitting Status.

\begin{tabular}{|c|c|c|}
\hline Facility name and/or description & Ares & Permit \\
\hline 221-T Containment System Test Facility & 200 West & $A / C$ \\
\hline Ash Pit Site & 200 Hest & $A / C$ \\
\hline E-8 Borrow Pit & 200 East & $A / C$ \\
\hline 242-A Evaporator/Crystallizer & 200 East & A/B \\
\hline Grout Treatment Facility & 200 East & $A / B$ \\
\hline T Plant Treatment Tank & 200 West & $A / B$ \\
\hline 241-2 Treatment Tank & 200 West & $A / B$ \\
\hline B Plant & 200 East & $A / B$ \\
\hline 222-S Laboratories Tank and Pad & 200 West & $A / B$ \\
\hline 204-AR Waste Unloading Station & 200 East & $A / B$ \\
\hline Plutonium-Uranium Extraction Plant & 200 East & $A / B$ \\
\hline Hanford Waste Vitrification Plant & 200 East & $A / B$ \\
\hline 2727-S storage Facility & 200 Hest & $A / C$ \\
\hline Double-Shell Tank Farms & 200 East and 200 West & $A / 8$ \\
\hline Hexone Storage and Treatment & 200 West & $A / C$ \\
\hline 2727-WA SRE Sodium Storage Building & 200 West & $A / B^{*}$ \\
\hline Plutonium-Uranium Extraction Tunnels 1 and 2 & 200 East & $A / B$ \\
\hline Transuranic Storage and Assay Facility & 200 West & $A / B$ \\
\hline Hanford Central Waste Complex & 200 West & $A / B$ \\
\hline Single-Shell Tank Farms & 200 East and 200 West & $A / C$ \\
\hline 207-A South Retention Basin & 200 East & $A / C$ \\
\hline Liquid Effluent Retention Facility & 200 East & $A / B$ \\
\hline 241-CX-70 Tank & 200 East & $A / C$ \\
\hline Low-Level Burial Grounds & 200 East and 200 West & $A / B / C$ \\
\hline 216-5-10 Pond and Ditch & 200 West & $A / C$ \\
\hline 2101-M Pond & 200 East & $A / C$ \\
\hline 216-A-29 Ditch & 200 East & $A / C$ \\
\hline 216-8-3 Pond & 200 East & $A / C$ \\
\hline 216-8-63 Trench & 200 East & $A / C$ \\
\hline 216-A-10 Crib & 200 East & $A / C$ \\
\hline $216-U \cdot 12 \mathrm{Crib}$ & 200 West & $A / C$ \\
\hline 216-A-36A Crib & 200 East & $A / C$ \\
\hline $216-A-37-1 \mathrm{Crib}$ & 200 East & $A / C$ \\
\hline
\end{tabular}

$A=$ Part A permit application.

$B=$ Part $B$ permit application.

$C=$ Closure/Postclosure plan.

- Application has been withdrawn. 
Closure/Postclosure Plan--Usually, a chapter of the Part B permit application that contains information on how the treatment, storage, or disposal waste management unit will be closed in accordance with WAC 173-303. At the Hanford Site, for treatment, storage, or disposal waste management units no longer operating, a closure/postclosure plan is submitted to the Ecology and the EPA for approval. If dangerous wastes are left in place, isolation and monitoring must be described in a postclosure chapter, and a postclosure permit application must be submitted.

Postclosure Permit Application--Similar to a Part B permit application, a postclosure permit application contains detailed information on the isolation and monitoring of any waste that is left in place at the waste management unit. Postclosure care usually is for a minimum of 30 years.

\subsection{PLANNING INTEGRATION}

Successful development of the 200 Areas requires coordinated planning both internally and with State and Tocal agencies. This section defines responsibilities for internal coordination and outlines the plans for State and local agencies near the 200 Areas. The integration of this Development Plan with the Hanford Site integrated planning process and 1.992 Hanford Mission Plan (RL 1992a) is also discussed.

\subsubsection{Responsibilities and Internal Coordination}

On the Hanford Site, the coordination of 1 and use and development plans is performed by the Westinghouse Hanford Company Site Planning Group with review and approvals from Westinghouse Hanford Company, PliL, Kaiser Engineers Hanford (KEH), Hanford Environmental Health. Foundation (HEHF), and in accordance with DOE Order 4320.1B (DOE 1991a). Site-selection activities are coordinated through the Hanford Site Selection Review Team, which is composed of representatives from each Hanford Site contractor and from departments within the operating contractor's organization. This review team is administered by the Westinghouse Hanford Site Planning Group with assistance from PNL, KEH, and HEHF. The administration is under the jurisdiction of the RL Site Infrastructure Division--Landlord and Facilities Management Branch, in accordance with RL Order 4320.2C (RL 1990) and DOE Order 6430.1A (DOE 1989).

With the projected increase in 200 Area population and a number of major tank farm operation, solid/liquid waste, analytical laboratory, tank waste remediation system, and support projects, clear communication among contractors and an adherence to long-range plans and site selection requirements will be required to avoid confilicts and ensure cost-effective results.

\subsubsection{State and Local Agencies}

Coordinated planning between RL, State, and local agencies will play a key role in successful development in the 200 Areas. 
Washington State has involvement in activities on the leased 1 and along the south side of the 200 Area Corridor. This applies to U.S. Ecology and would apply to proposed facilities located on the State-leased 1 and.

The Benton County Public Utility District provides electrical power to U.S. Ecology and would probably provide service to any other users on the Washington State-leased 1and. The Benton County Public Utility District might al so serve privately operated facilities that may be sited at the 200 Areas. The Benton County planning department would be involved in providing easements/rights-of-way for utilities, such as the potential natural gas line to the 200 Areas.

\subsubsection{Hanford Site Integrated Planning Process and 1992 Hanford Mission Plan}

The Hanford Site integrated planning process is documented in the 1992 Hanford Mission Plan (RL 1992a) and multi-year program plans.

The 1992 Hanford Mission Plan provides a Site-level summary of the technical and operational direction for the Hanford Site's primary mission of environmental restoration and other mission areas. It develops the overall top-level logic and the technical interrelationships among the mission areas and lays out the key broad schedule and technical milestones.

The Hanford Site Development Plan (DOE/RL-89-15) (DOE-RL 1990a) and individual area development plans will provide analysis and baseline guidance for land use and physical development in accordance with mission and multiyear program plans.

The integration of development plans with the 1992 Hanford Mission Plan and the Hanford Site integrated planning process creates an iterative process, resulting in effective baseline decisions that support the Hanford Site mission areas. This integration process enhances the long-term 1 and use and development guidance outlined in Site development plans. Figure 2-27 depicts this relationship.

\subsection{LAND USE}

This section provides existing and long-range land-use drawings to help visualize future development in the 200 Areas and provide a decision-making tool for project planning and site selection.

\subsubsection{Land-Use Categories}

Land-use categories provide a method for identifying and projecting the use of DOE property. They are similar to land-use zoning regulations administered by cities and counties in that they provide guidelines for ensuring efficient and desirable development. 
Figure 2-27. Development Planning Integration.

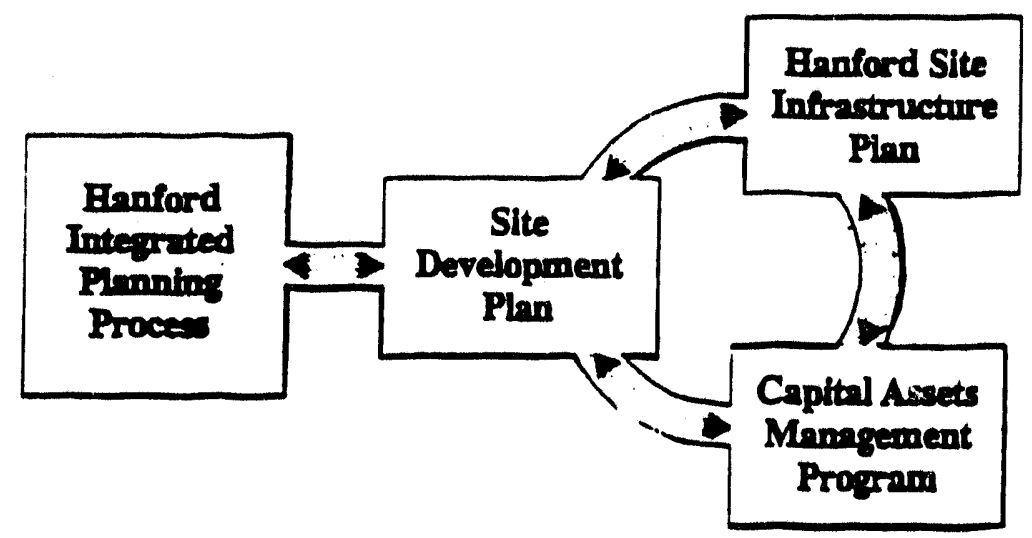

The RL land-use categories are based on activity types, not programmatic ownership or contractor function. They are applied according to the existing and projected uses of the land. Through the use of these categories, existing land uses are identified, and suitable areas for future development are reserved.

The Hanford Site Development Plan (DOE/RL-92-20) (Hathaway 1992) provides an overview of land uses at the Hanford Site. The Hanford Site Development Plan identifies the primary use for the 200 Areas as "waste operations." This use category reflects the potential baseline cleanup scenario where Sitewide wastes are collected and stored in a central location for exclusive use as a waste disposal area. This includes the relocation of waste sites and associated structures, such as the 100 Area facilities. This Development Plan further divides the waste operations use into specific zoning to support required waste operations uses.

There are eight Hanford Site land-use categories: three operations categories, two support categories, a research and development/engineering development category, a sensitive areas category, and an undeveloped land category. Seven land-use categories are applicable to the 200 Areas in the existing planning timeframe and five land-use categories are applicable in the long-range planning timeframe.

Each source and groundwater operable unit is identified as an overlay zone of these land-use categories. The operable unit overlay zones are identified when the characterization of waste management units and the development of cleanup plans begin, and would be removed when remediation activities are completed. These overlay zones are considered temporary based on the assumption that the land within the source operable units will be cleaned up to a level that allows new uses when remediation activities are completed. 


\subsubsection{Hanford Site Land-Use Category Definitions}

The land-use category definitions are as follows.

- Reactor Operations: Development and irradiation of nuclear fuels. This includes the following:

- Fuel fabrication

- Fuel storage

- Reactor plant operations

- Associated electrical power production

- Storage of advanced materials

- Dedicated support activities located directly at the operating site (i.e., maintenance, engineering, administration).

- Reprocessing Operations: Separation of spent nuclear fuels and refinement of special nuclear material. This includes the following:

- Spent fuels storage

- Reprocessing plant operations

- Nuclear materials refinement plant operations

- Storage of special nuclear material

- Dedicated support activities located directly at the operating site (i.e., maintenance, engineering, administration).

- Waste Operations: Treatment, storage, or disposal of radioactive and nonradioactive wastes. This includes the following:

- Waste treatment facility operations and active and inactive tank farms

- Burial grounds/landfills

- Vaults

- Cribs

- Basins

- Ditches

- Trenches

- Dedicated support activities located directly at the operating site (i.e., maintenance, engineering, administration).

- Operations Support: Provides services to operations. Activities are primarily industrial in nature. This includes the following activities:

- Steam plant

- Shops

- Laundry

- Regulated maintenance

- Dry materials handling

- Crane and rigging

- Utilities/infrastructure

- Maintenance

- Construction

- Warehousing and storuge 
- Roads and streets

- Railroads

- Safeguards and security

- Fire protection

- Applied technology laboratories.

- Administrative Support: Provides general purpose office services for overall Hanford Site activities. This includes the following general purpose systems and facilities:

- General engineering

- Administration.

- Research and Development/Engineering Development: Development and adaptation of innovative technologies. This includes the following:

- Interdisciplinary research

- Development of engineering solutions

- Laboratory analysis

- Computing activities

- Prototype development

- Demonstration

- Testing.

- Sensitive Areas: Ecologically and/or historically significant areas. This includes the following:

- Land or facilities that are environmentally sensitive

- Wildlife refuges

- Historically significant, archaeologically significant, or ecological research areas.

- Undeveloped Areas: Areas that have not been developed or have been restored to an undeveloped state.

- Operable Unit Overlay Zone: An area identified for characterization and remediation of 1 and and groundwater. This includes the following:

- Demolition

- Cleanup

- In situ stabilization

- Restoration

- Postclosure monitoring

- Dedicated support activities located directly at the operable unit site (i.e., maintenance, engineering, administration).

Section 2.5 provides a description of these operable unit activities. 


\subsubsection{Areas Existing Land-Use Plan}

As shown in Figure 2-28, the 200 Areas are divided into seven 1 and-use categories: reprocessing operations, waste operations, operations support, administrative support, research and development/engineering development, sensitive areas, and undeveloped areas.

The reprocessing operations areas are located at the PUREX PIant and $\mathrm{B} P \mathrm{Plant}$ in the 200 East Area and the PFP and $\mathrm{UO}_{3} \mathrm{Pl}$ ant in the 200 West Area. Currently, the 202A PUREX Canyon and Service Facility is in a standby status. Currently, B Plant is involved in waste encapsulation and storage. The PFP is in preparation for restart and the $\mathrm{UO}_{3} \mathrm{Plant}$ is in standby status.

The waste operations area is the largest land-use category in the 200 Areas. The past operation of fuel fabrication and laboratory activities at the Hanford Site created a number of waste storage and disposal sites in the 200 Areas. The waste operations area is designed to provide for the treatment, storage, or disposal of wastes. These areas are located throughout the 200 Areas and will eventually be closed and covered or cleaned up and released for new uses.

The operations support areas are designed to provide for services directly related to operations and to serve as a buffer between operations uses and administrative support and research and development/engineering development uses. The operations support areas are located in the southwest corner of the 200 East Area and the east-central and southern portions of the 200 West Area.

The administrative support areas are designed to provide for services directly related to overall 200 Areas and Hanford Site activities.

Administrative support areas are located in the southwestern corner of the 200 East Area and the east-central portion of the 200 West Area.

The research and development/engineering development area is located in the 200 Area Corridor. The Hanford Weather Station is located in this area. The PNL Atmospheric Sciences Department has a continuing interest in maintaining the area around the Hanford Weather Station for use in future meteorological field measurement programs. Future development in this area may be restricted to establish a representative "microclimate" in which measurements can be carried out (see Appendix D).

The Historic White Bluffs Road that crosses diagonally through the 200 West Area is the only sensitive area in the 200 Areas. This road is considered to be eligible for the National Register. Development of 1 and on and/or along the road will be done only after all other alternatives have been exhausted and measures have been used to mitigate impacts.

The undeveloped areas are located throughout the 200 Areas. These undeveloped areas have been primarily undisturbed with minimal infrastructure and/or facility development. 
DOE/RL-92-29

Figure 2-28. 200 Areas Existing Land-Use P1an.

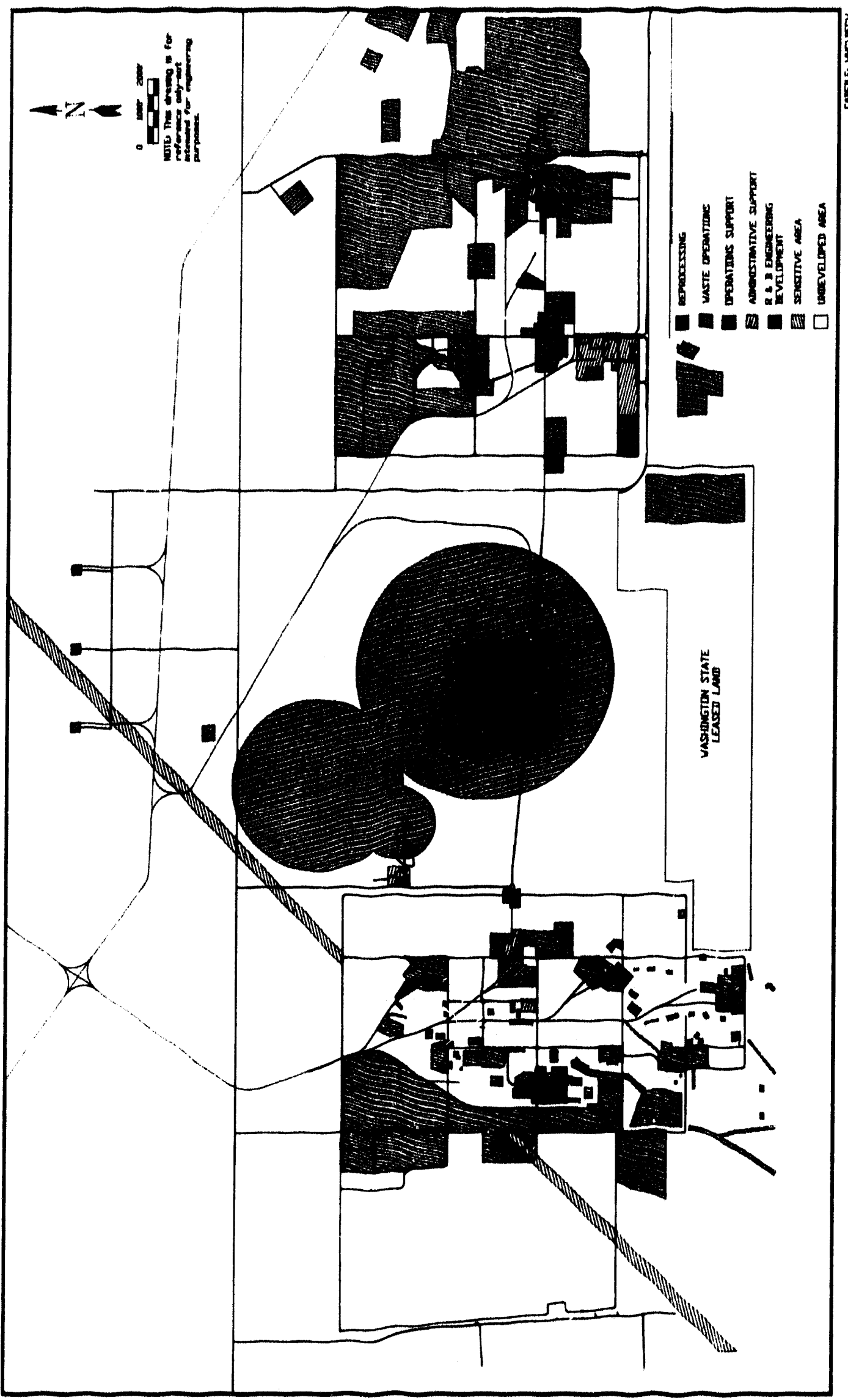


Operable Unit Overlay Zones 200-BP-1 and 200-UP-2 will be active through the next 5 to 15 years. Activities will consist of characterization and development of cleanup plans. The start of actual cleanup of these two operable unit overlay zones should begin sometime in FY 1996 and FY 1998, respectively.

\subsubsection{Areas Long-Range Land-Use Plan}

Significant development is expected to occur in the 200 Areas during this planning timeframe (20 years) based on the mission to transform the Hanford Site into the nation's model for excellence in environmental management. This includes demonstration and application of advanced technologies, restoration of 1 and, and creation of facilities for other productive uses. This mission and the expanding waste operations activities play a major role in the future development of the 200 Areas.

As shown in Figure 2-29, the 200 Areas are divided into six land-use categories: waste operations, operations support, administrative support, research and development/engineering development, sensitive areas, and undeveloped areas.

During this planning timeframe, reprocessing operations will be replaced by waste operations in which the facilities will be shutdown and enter decontamination and decommissioning.

The waste operations area will expand significantly during this planning timeframe. In the 200 East Area, waste operations activities will expand with the construction of the HWVP, which is the cornerstone of the Tank Waste Remediation System. In addition, depending on the process selected for disposal of LLW from SSTs, a large complex of grout vaults may be required. One scenario (Boomer et ai. 1991) identifies a possible requirement for as many as 139 vaults. This would require an area three times the size of the area currently reserved on the east end of the 200 East Area for grouted LLW from DSTs. The area reserved on the east end of the 200 East Area is 59.693 hectares ( 147.5 acres). Existing burial grounds will also be closed and covered during this timeframe.

In the 200 West Area, the waste operations area will expand in support of solid waste management 1 and requirements. These land requirements include the construction of HCWC facilities and expansion of burial grounds in the west end of the 200 West Area. Existing burial grounds will be closed and covered. A new tank farm and perhaps a pretreatment module could also be constructed north of the 241-SY Tank Farm. It is anticipated that additional facilities associated with disposal of tank wastes could be located along the cross-site transfer line near U Plant in the southeast part of the 200 West Area. 


$$
\text { DOE / RL-92-29 }
$$

Figure 2-29. 200 Areas Long-Range Land-Use Plan.

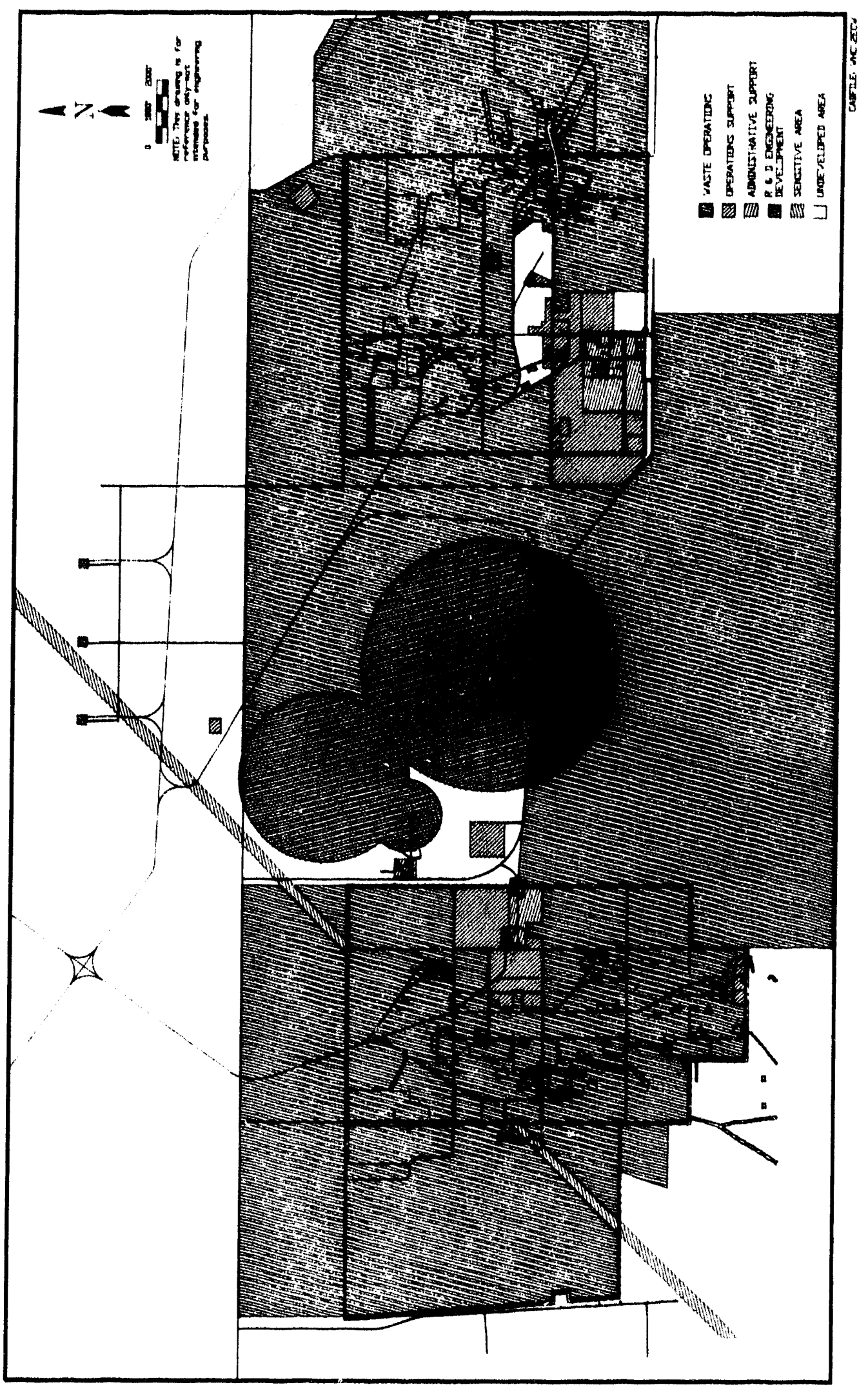


In the 200 Area Corridor, the waste operations area will expand because of the increasing need for replacement of old waste treatment, storage, or disposal facilities, the application of new technology to the Tank Waste Remediation System mission, and the potential development of a monitored waste disposal system complex. Some of these facilities are extremely large (ranging in size from 16 hectares to $15.5 \mathrm{~km}^{2}$ [39.5 acres to $6 \mathrm{mi}^{2}$ ]. The 200 Area Corridor provides the large areas of undeveloped land that could accommodate this type of development. In addition, the cross-site transfer line, which crosses the southern part of the corridor, provides easy access to liquid waste from all tank farms in the 200 Areas.

The operations support area will expand in the 200 East Area with the construction of shops, warehouses, maintenance facilities, and possibly a new steam plant. The administrative support area will expand with the construction and/or placement of office facilities to accommodate growth. The Hanford Weather Station and PNL's proposed construction restriction area around the station will continue to be designated research and development/ engineering development. The Historic White Bluffs Road will continue to be designated as a sensitive area. Undeveloped areas will continue to exist within the 200 Areas. The majority of undeveloped areas will be located outside the perimeter fence lines and may require long utility extensions to accommodate development.

The remaining 35 operable unit overlay zones will be active during this timeframe. Activities will consist of characterization and development of cleanup plans. The start of actual cleanup of these remaining 35 operable unit overlay zones is identified in Section 2.5. Cleanup of Operable Unit Overlay Zones 200-BP-1 and 200-UP-2 should be near completion. 
DOE/RL-92-29

This page intentionally left blank. 


\subsection{CONCLUSIONS}

This section summarizes the recommendations developed throughout the planning analysis and master planning processes contained in this Development Plan. All existing and currently planned projects can be accommodated.

\subsection{WASTE COLLECTION OR TRANSFER LINES}

The following projects will install waste collection or transfer lines:

- Project $\mathrm{C}-018 \mathrm{H}, 242-\mathrm{A}$ Evaporator/PUREX Plant Condensate Treatment Facility

- Project W-028, Aging Waste Transfer Lines

- Project $W-049 H, 200$ Area Treated Effluent Disposal Facility

- Project W-058, Replacement of the Cross-Site Transfer System

- Project W-087, Radioactive Liquid Waste Line Replacement.

The feasibility of placing different combinations of these pipes in common trenches or transfer corridors needs to be studied. The common trench approach could have cost and potential environmental benefits. Both the common trench and transfer corridor concepts would be more efficient from a land-use perspective.

\subsection{WASTE SAMPLING AND CHARACTERIZATION FACILITY}

The Waste Sampling and Characterization Facility design currently includes a laboratory building and a data processing/data storage building. This facility will not operate efficiently until the appropriate amount of office and support facilities are located with it. This issue is currently being analyzed.

\subsection{INFRASTRUCTURE ISSUES}

Primary infrastructure issues in the 200 Areas are as follows.

General Purpose Facilities. The 200 Areas are experiencing a critical office space shortage. As of September 1992, the 200 East and 200 West Areas were approximately 1,030 work stations short, including inadequate space, and at the current projected growth rate, the 200 Areas will need an additional 870 work stations by the end of FY 1997. Of the 1,030 work station shortage, 650 work stations are inadequate. In order to vacate this inadequate space, capital dollars must be available for the construction of new space.

Capital projects are planned to address this need but cannot respond within the timeframe required.

Analytical Laboratories. The Hanford Site analytical laboratories are in transition to support the cleanup mission. Analytical laboratory services are needed to handle LLW samples as well as dangerous and/or hazardous waste samples. This service will be provided in part by the Waste Sampling and 
Characterization Facility, which is currently under construction. Additional analytical needs may be met by offsite commercial laboratory services. In addition, expansion of hot cells needed for analysis of highly radioactive samples is under way. The source of analytical support for TRU waste is not identified at this time.

Roads. The road network north of the Wye Barricade will require major upgrades to support construction, operation, and disposal activities. The shift in location of major work centers, significant construction and disposal hauling requirements, and the age and design of existing roads dictate the need for major improvements.

Telecommunications. An upgrade is under way for a Sitewide communications network to provide the basic technology and support to future activities across the Site.

Fire. A raw-water reservoir and pumps are needed in the 200 Areas for fire protection.

Laundry. Additional loads on laundry and respirator-cleaning facilities are anticipated with the start of buried waste retrieval activities and the startup of new facilities. A contract has been made with a commercial company to provide the Hanford Site's decontamination laundry services at a new facility to be located in Richland. This facility needs to be built and operated. The existing facilities need to be decommissioned.

Railroad. The railroad network requires maintenance for continuity of operations and could require significant expansion to support bulk transport, environmental restoration activities, new burial grounds, burial grounds closure covers, and building decontamination and decommissioning. Some rail spurs will need to be removed or relocated to allow burial grounds to be closed. A rail car maintenance facility is planned for preventive and corrective maintenance to rail equipment in the outer areas.

Electrical. Westinghouse Electrical Utilities operates the DOE transmission and distribution network in the 200 Areas. Coordination between project management and Westinghouse Electrical Utilities is needed to provide the significant transmission line extensions required to support new facilities and retrieval activities. Ten power lines in the 200 Areas must be converted from $2,400 \vee$ to $13,800 \mathrm{~V}$ for safety and reliability.

Steam. Steam will be required to support existing and new facilities. The 200 Areas' steam system requires reliability upgrades. Alternatives (including private sector participation) are being evaluated for replacing the aging central steam plants and reducing steam requirements in the 200 Areas.

Water. Raw water is pumped to the 200 Areas from the Columbia River at the $100 \mathrm{~B}$ and $100 \mathrm{D}$ Areas via the export water system. Upgrade of services to support new facilities in the 200 Areas will be required, including a sanitary water reservoir and pumps and extension of fire mains.

Process Sewer. Treated effluent disposal facilities are being constructed in the 200 Areas to collect, store, treat, and dispose (process) effluent streams. 
Sanitary Sewer. The construction of a central collection, treatment, and disposal plant in the 200 Areas is being considered to handle a sanitary sewer system. Ariticipated construction of new acilities, increased personnel, changing environmental regulations, and growing concerns about the current systems' ability to handle projected needs drives this requirement. Sanitary wastes are currently disposed of through septic tanks and drain fields.

Natural Gas. Natural gas is being considered as an alternative energy source to repiace coal-fired steam production in the 200 Areas. The use of gas could save money and create a healthier environment.

Equipment Decontamination/Maintenance. Equipment decontamination and maintenance facilities are currently inadequate or nonexistent. The facilities at $T$ Plant are in need of major upgrades or replacement, the Regulated Equipment Maintenance Facility needs to be replaced, and a facility to provide maintenance to contaminated rail cars does not yet exist. 
DOE/RL-92-29

This page intentionally left blank. 


\subsection{MASTER PLANNING}

The master plans show changes in the configuration of the 200 Areas over the next 20 to 30 years. Development of these plans is based on the information and analys is in Sections 2.0 and 3.0. Topics covered in this section include future land use and functional location, facility and mission planning, utilities, transportation, security, and environmental issues.

\subsection{INDIVIDUAL MASTER PLAN DRAWINGS}

This section provides separate master plans for areas that will be experiencing the greatest amount of development throughout the planning timeframe. This section also presents an overall master plan for the 200 Areas.

\subsubsection{East Area}

4.1.1.1 Core Area. The 200 East Core Area is south of 4 th Street, west of Baltimore Avenue, and north and east of Route 4S. The core area is reserved for consolidation of administrative and support activities for the 200 Areas. This consolidation increases productivity and reduces costs.

Further development of the core area has been planned to provide capacities to accommodate future construction. The existing 200 East core Area improvements are diagrammed in Figure 4-1.

Five-Year Plan. New facilities are required to accommodate increasing population, collocate personnel, vacate inadequate facilities, and expand support activities in the 200 Areas. These new facilities will support proposed cleanup projects. Downgrading security in the 200 Areas to a property protected area, except for specific buildings and areas, could allow the 200 East Core Area to be downgraded to unrestricted access.

The proposed 5-year development of roads, parking lots, and facilities are outlined in Figure 4-1 and the utility corridors in Figure 4-2. The significant access, facility developments, and utilities proposed are as follows:

- Fabrication Facility (K-003)

- 200 East Office Facility (L-091)

- Engineering and Administrative Offices (K-004, others not programmed)

- Two 16-wide Modular Offices (L-142)

- Parking to support increase in population (not programmed)

- General Support and Electrical Utilities Complex (L-112)

- Outer Areas Fuel Station (L-044) 
Figure 4-1. 200 East Core Area Master Plan.

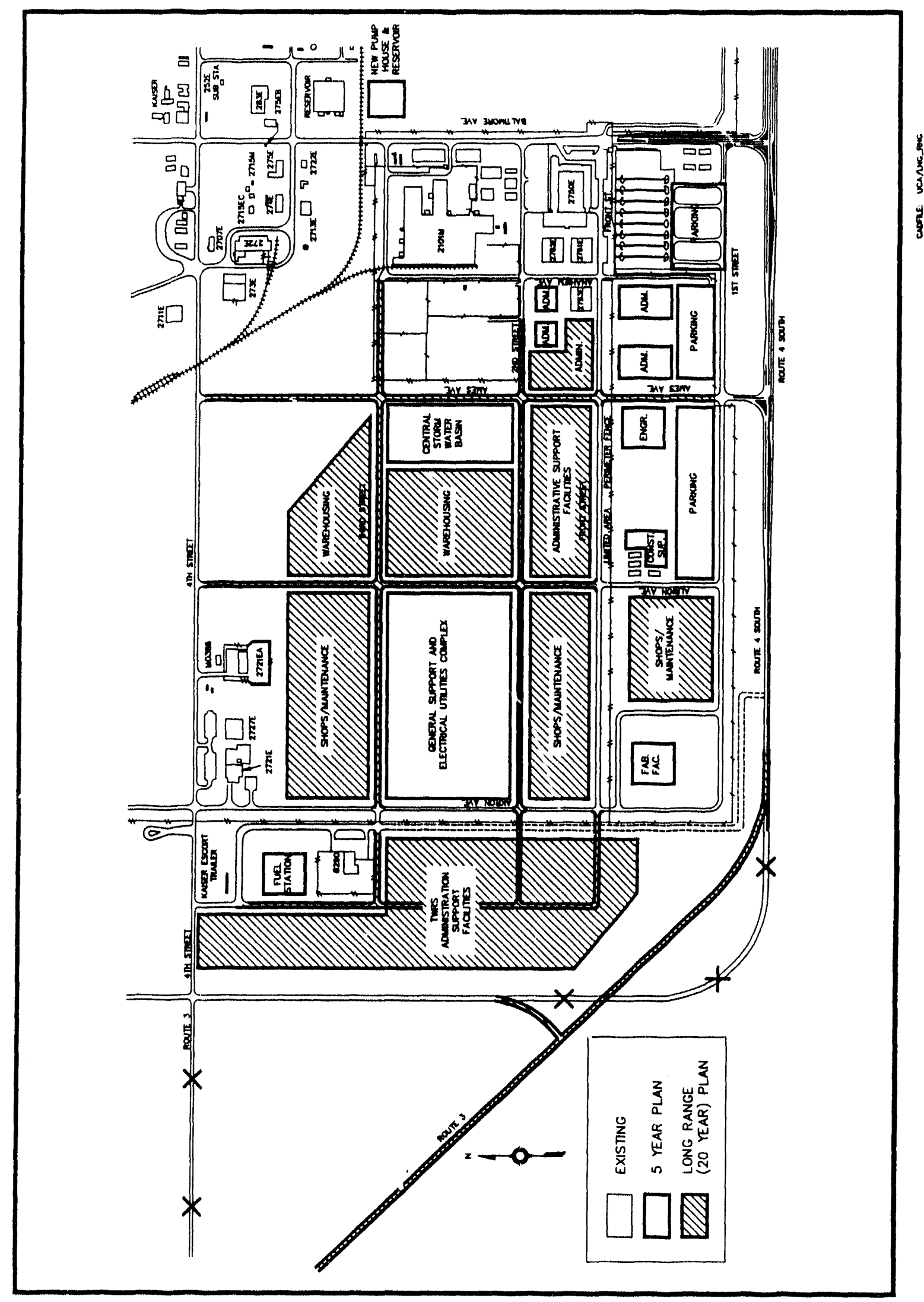


$D O E / R L-92-29$

Figure 4-2. 200 East Core Area Master Plan--Utilities.

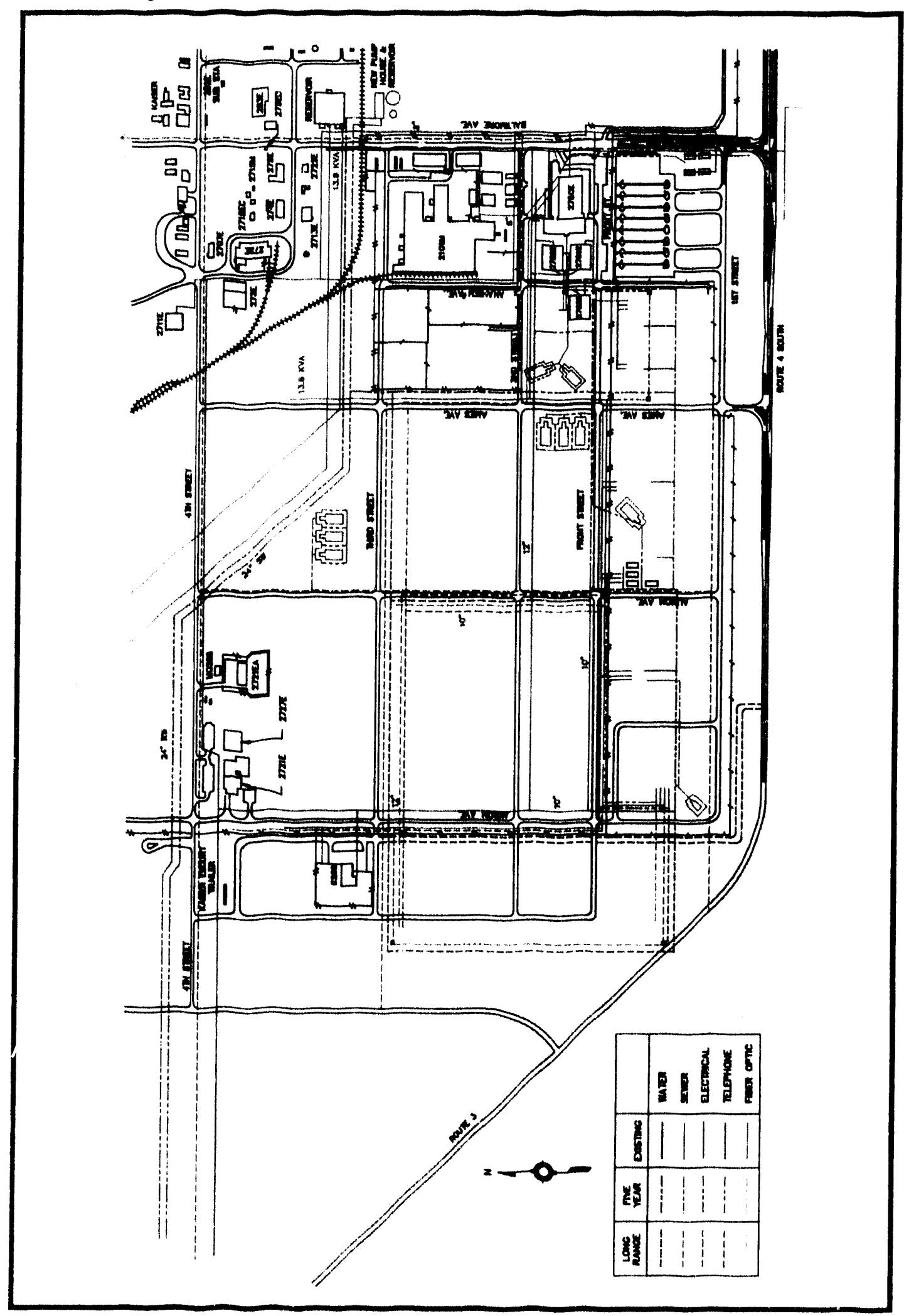


- 200 East/West Cross-Site Water Line (B-604)

- Roads and utilities expansion to support development (not programmed)

- 200 Area Sanitary Sewer System (L-116)

- Upgrade or Reconstruct Route 3/4S Intersection (L-102).

Lonq-Range Plan. The long-range plan for future 200 East Core Area expansions are shown in Figures 4-1 and 4-2, and consist of road extensions and utility corridors to support future projects.

The long-range $\mathrm{plan}$ emphasizes the following:

- Expansion of warehouse and storage space

- Engineering and administrative support facilities

- Shops and maintenance facilities

- Tie-in sewer lines to collection system

- Roads and utilities expansion to support development

- Expansion of telephone/HLAN communications network.

4.1.1.2 Grout Treatment and Disposal and the 241-A Tank Farms. Figure 4-3 diagrams the planned development of the land around 241-A Tank Farms and the grout treatment and disposal facilities.

241-A Tank Farm. Waste tank support personnel located in the 2750-E Building and other offices are to be relocated to the immediate area around the 272-AW Building. This will increase productivity and reduce costs by centrally locating and placing employees close to the tank farms, evaporator, Liquid Effluent Retention Facility, and Effluent Treatment Facility. In addition to upgrades to existing facilities, the following projects are planned to develop this centralized location:

Project Description Schedule

\begin{tabular}{|c|l|l|}
\hline W-225 & Tank Farm Support Complex & FY 1996 line item \\
\hline W-188 & Tank Farm Radiological Support Facilities & FY 1995 l ine item \\
\hline W-116 & Tank Farm Office Facility & $\begin{array}{l}\text { FY 1991 general } \\
\text { plant project }\end{array}$ \\
\hline W-182 & 272-AW Facility Addition & FY 1994 line item \\
\hline
\end{tabular}

Grout Disposal Vaults. Grout Operations plans to have 44 vaults filled by the year 2015. One vault has been constructed and filled, four other vaults are near construction completion (B-714) and will be filled. 
DOE/RL-92-29

Figure 4-3. 241-A Tank Farms and Grout Treatment and Disposal Master Plan.

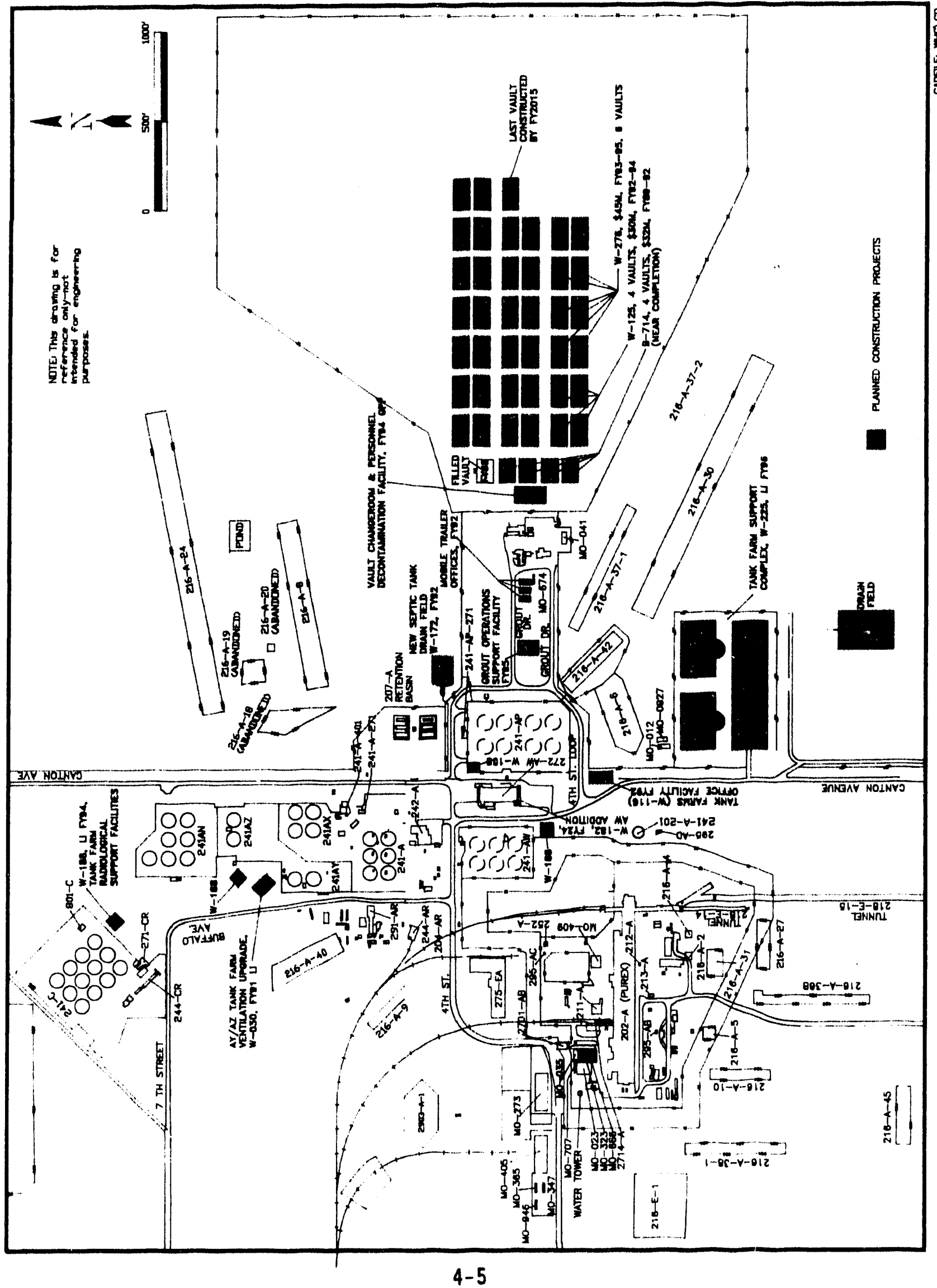


To support the continued construction and filling of these vaults, the following projects are planned:

\begin{tabular}{|c|c|c|}
\hline Project & Description & Schedule \\
\hline-- & $\begin{array}{l}\text { Grout Operations Support } \\
\text { Facility }\end{array}$ & FY 1995 general plant project \\
\hline-- & $\begin{array}{l}\text { Vault Changeroom and Personnel } \\
\text { Decontamination Facility }\end{array}$ & FY 1994 general plant project \\
\hline-- & Mobile Offices & FY 1992 project \\
\hline$B-714$ & Construct Four Vaults & FY 1989 to 1992 expense project \\
\hline$W-125$ & Construct Four Vaults & FY 1993 to 1995 expense project \\
\hline$H-276$ & Construct Four Vaults & FY 1994 to 1996 expense project \\
\hline$\overline{--}$ & Construct Additional Vaults & Through FY 2015 \\
\hline
\end{tabular}

PUREX Plant: Because of the termination of PUREX Plant operations, a 11 construction projects planned for the PUREX Plant are suspended.

As PUREX Plant operations decrease, its reduced usage of utilities, roads, buildings, and land will need to be identified. The variance in usage of these items can support Site infrastructure development. Project cost savings can be realized where the capacity added back to the utilities, roads, and facilities can be reused.

4.1.1.3 Treated Effluent Disposal Area Master Plan. The Treated Effluent Disposal Area is outside the perimeter fenceline in the northeast corner of the 200 East Area. The master plan (Figure 4-4) for this area represents a synthesis of projects. These projects are as follows:

\begin{tabular}{|l|l|} 
Project & Description \\
\hline C-018H & 242-A Evaporator/PUREX Plant Condensate Treatment Facility \\
\hline W-049H & 200 Area Treated Effluent Disposal Facility \\
\hline W-105 & $242-A$ Evaporator Liquid Effluent Retention Facility \\
\hline W-177 & 200 East Effluent Operations Support Facility \\
\hline
\end{tabular}

Construction and operation of these four projects will result in interfaces with one another to retain, treat, and dispose of treated liquid effluents. Project $\mathrm{W}-\mathrm{O} 49 \mathrm{H}$ will upgrade the Project $\mathrm{W}-105$ retention basins and the Project $\mathrm{C}-\mathrm{O} 18 \mathrm{H}$ facility to enable their acceptance of Project $\mathrm{W}-\mathrm{O} 49 \mathrm{H}$ effluents. Project $\mathrm{W}-049 \mathrm{H}$ will provide the collection piping and disposal systems for the 200 Area effluent streams to which best available technology has been applied. Retention basins were constructed (Project W-105) to hold effluent collected by the system constructed with Project $\mathrm{W}-049 \mathrm{H}$. 
Figure 4-4. Treated Effluent Disposal Area Master Plan.

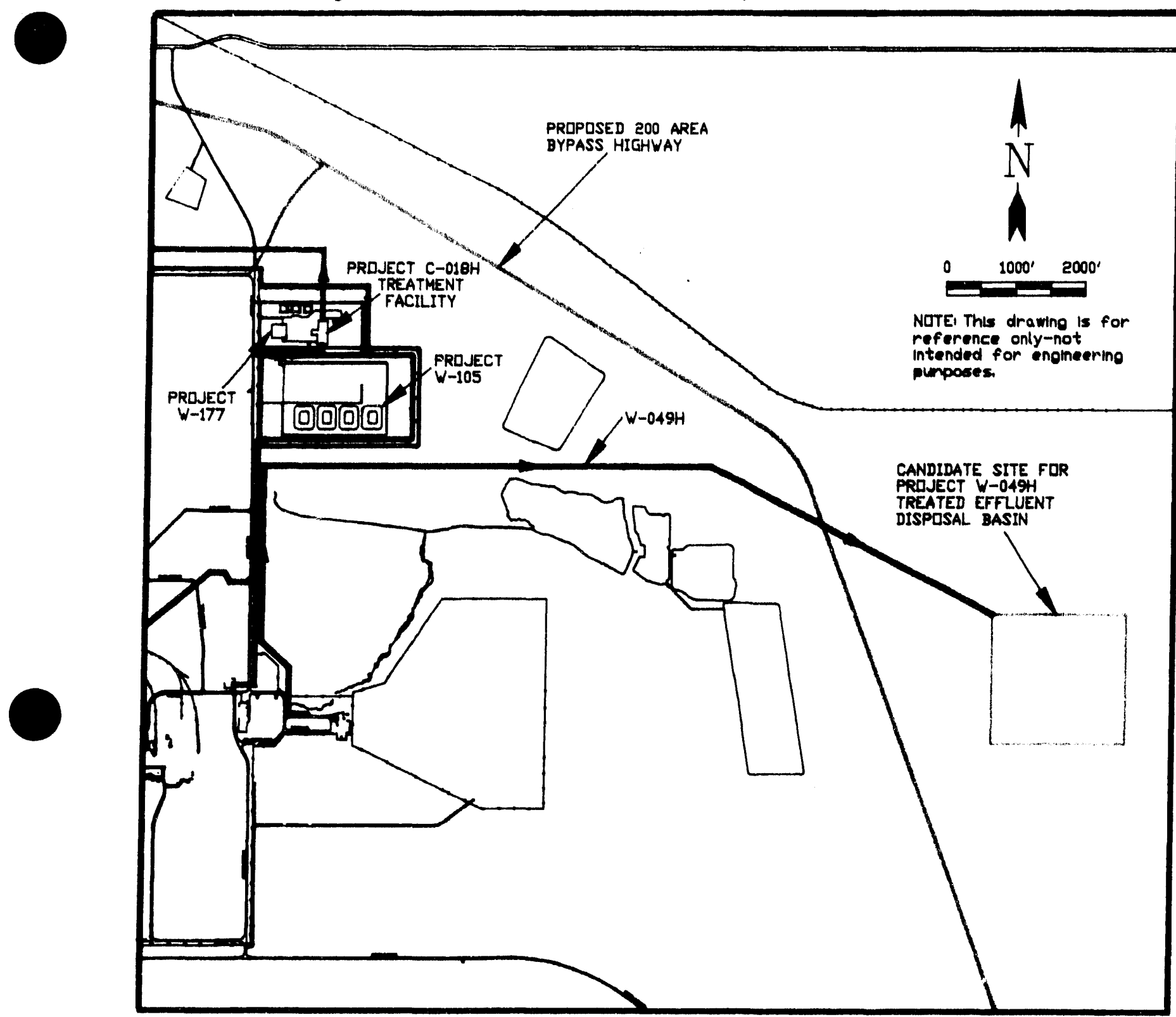

CADFILEI WHCITED 
Project $\mathrm{C}-018 \mathrm{H}$ will provide standby treatment and disposal for Project $\mathrm{W}-\mathrm{O} 49 \mathrm{H}$ effluents that exceed the Treatment Effluent Disposal Facility discharge limits. Project $W-177$ will provide office space to support effluent treatment operations. This project will increase productivity by locating effluent treatment personnel near the new operating facilities for Projects $\mathrm{W}-105, \mathrm{C}-018 \mathrm{H}$, and $\mathrm{W}-049 \mathrm{H}$.

Construction for Project $\mathrm{C}-\mathrm{O} 18 \mathrm{H}$ is scheduled for completion in the third quarter of FY 1994 with startup in the first quarter of FY 1995. Construction for Project $\mathrm{W}-\mathrm{O} 49 \mathrm{H}$ is scheduled for completion in the fourth quarter of FY 1994 with operation startup in the first quarter of FY 1995. Project W-177 is scheduled for completion in FY 1994.

The treated effluent disposal area master plan, Figure 4-4, outlines land-use plans, infrastructure development, utility corridors, and areas of future expansion for the four projects listed previously. Figure 4-5 identifies the collection system for Project $\mathrm{W}-\mathrm{O} 49 \mathrm{H}$.

\subsubsection{Area Corridor}

The Tank Waste Remediation System is an approach to resolving waste tank safety issues and achieving final disposal of SST and DST wastes. The HWVP is the cornerstone for the Tank Waste Remediation System. Other aspects include new tanks, pretreatment modules (including hot pilot plant), evaporator, and analytical and support facilities. Several of these could be in major system acquisition cost ranges. A systems engineering approach to integrating project and operating plans will prevent unnecessary spending during the facilities life cycles.

The most promising location for Tank Waste Remediation System facilities is close to and directiy west of the HWVP. This area has no secondary infrastructure, but primary roads, rail, water, steam, electrical power, and waste transfer capabilities exist on or near its borders. Optimum arrangement of facilities is currently being studied. Figure 4-6 shows three alternative sites currently being evaluated for a 40.5 hectare (100-acre) Tank Waste Remediation System pretreatment/tank farm complex with 16.2 hectares (39.5 acres) for expansion.

\subsubsection{West Area}

Solid Waste Management is developing the HCWC in the west end of the 200 West Area. The HCWC will provide facilities for processing radioactive and hazardous solid waste materials in accordance with government regulations. Also, the complex will contain various facilities that will support waste treatment, storage, or disposal. 
$\mathrm{DOE} / \mathrm{RL}-92-29$

Figure 4-5. Collection System for Treated Effluent Disposal Facility.

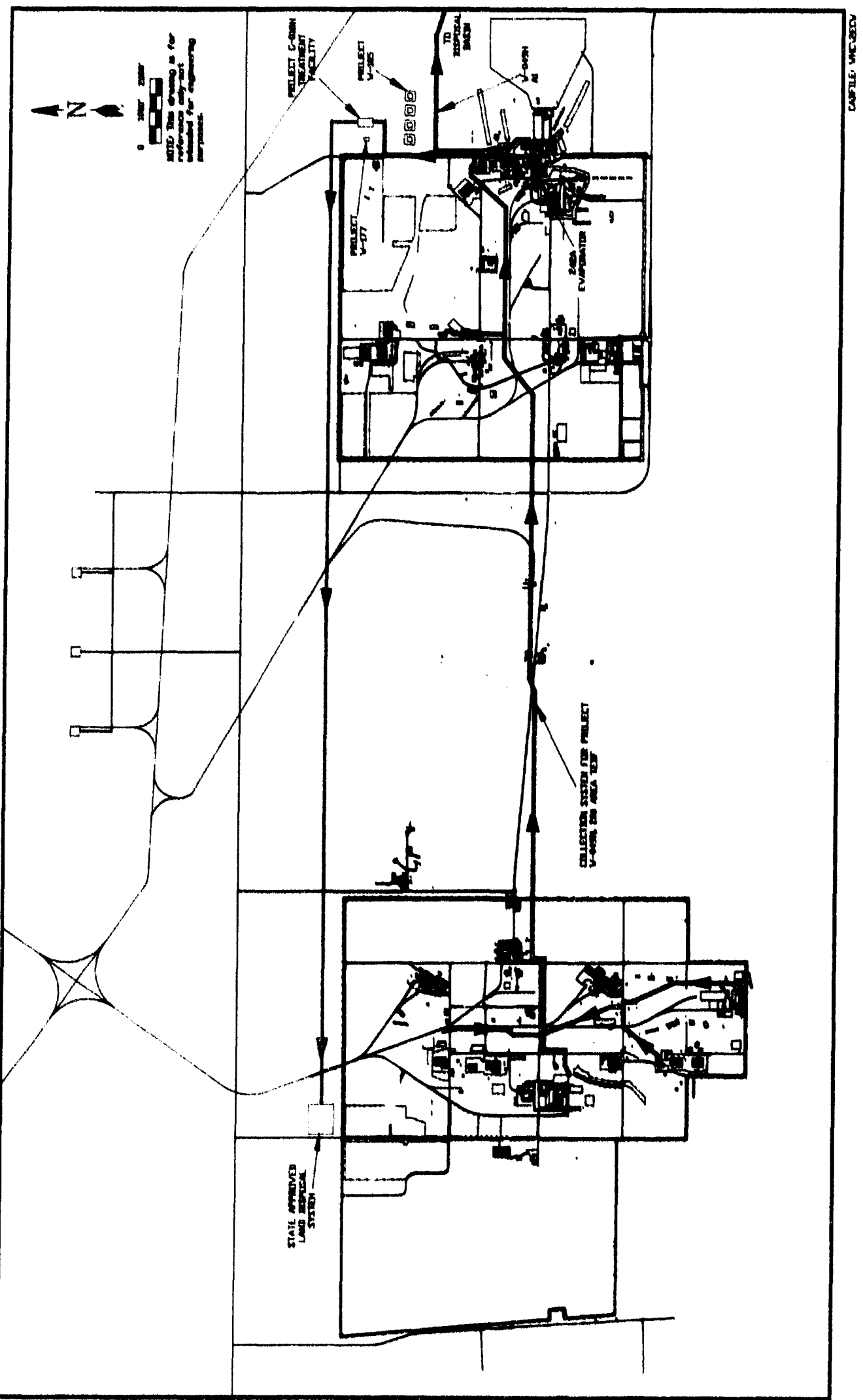


DOE/RL-92-29

Figure 4-6. Tank Waste Remediation System Development Conceptual Plan.

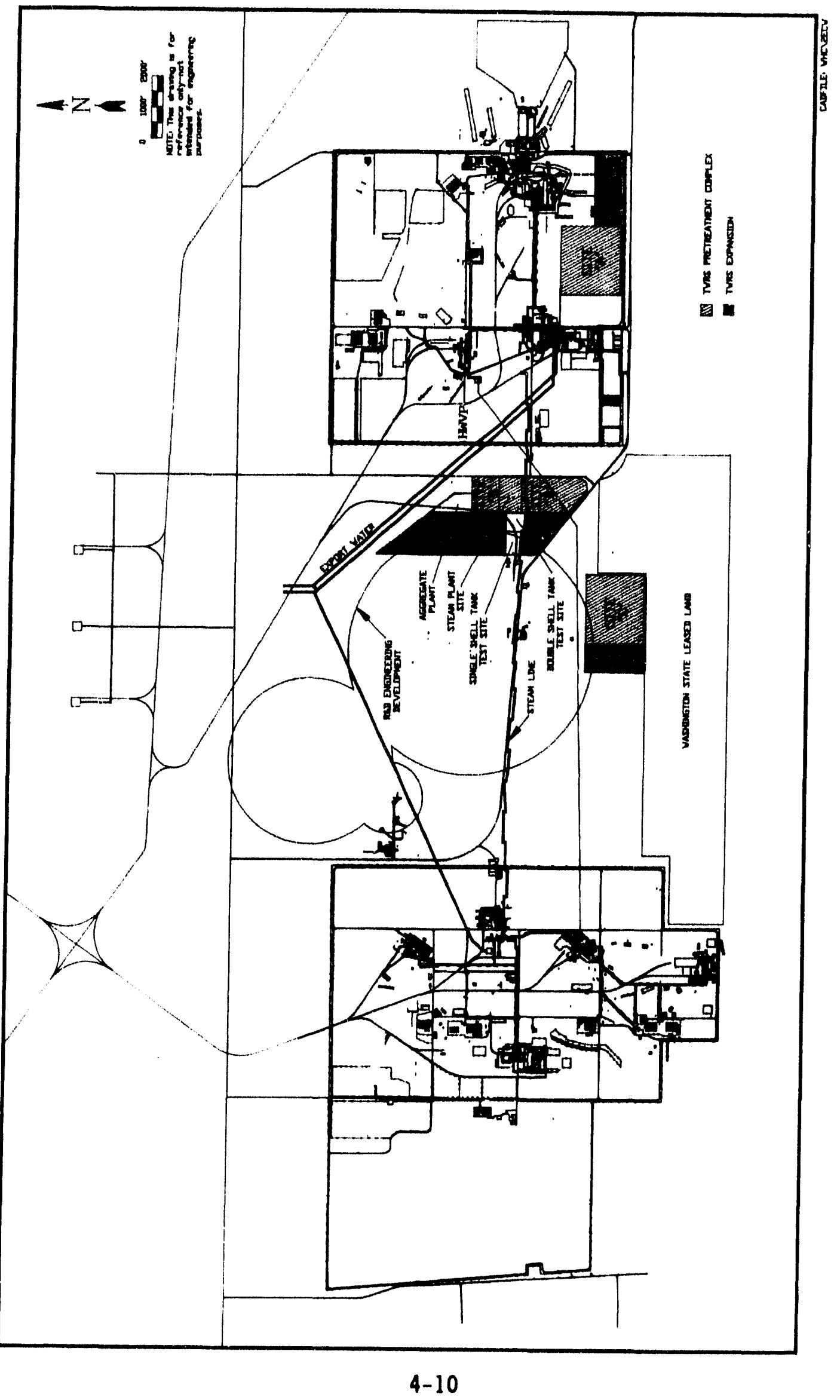


Some funded, budgeted, and planned projects for the HCWC and immediate vicinity are Waste Receiving and Processing Modules 1, 2A, and 2B; Hanford Central Waste Support Cumplex; Enhanced Radioactive And Mixed Waste Storage Phase V; Solid Waste Retrieval Phases I and II; Alpha Caisson Retrieval; waste alkali metal storage; remote-handled storage; greater-than-Class 3 storage; Radioactive Mixed Waste Cisposal Facility; Enhanced Solid LLW Disposal; and the Waste Reduction and Reclamation Facility.

These projects wili increase the number of staff by several hundred and increase the traffic at and near the HCWC. Figure 4-7 shows the master plan for the HCWC. Figure 4-8 shows the utilities master plan for the HCWC.

\subsection{AREAS MASTER PLAN}

Figure 4-9 shows the overall master plan for development of the 200 Areas. It provides a vision of what the baseline cleanup efforts will require in the 200 Areas over the next 30 years. It includes a combination of mission projections, population forecasts, facilities and infrastructure planning, and the previously outlined master plans. The master plan shows that the 200 Areas' boundaries must expand (1) into the corridor to accommodate Tank Waste Remediation System activities, (2) to the south to accommodate low-level tank waste disposal and ERSDF, and (3) to the east and north to accommodate treated effluent disposal activities.

\subsection{DEVELOPMENT STANDARDS}

To integrate architectural design and develop a more pleasing environment, a number of development standards are proposed. These standards are intended for use in guiding future planning and design efforts. The use of these standards, where possible, will allow continued development of facilities and grounds over a long period of time, and promote life cycle, cost effective, energy efficient buildings, while maintaining continuity of function and appearance within the areas.

\subsection{1 Àrchitectural Standards}

The only architectural standard proposed is that multistory buildings should be used in place of single-story buildings to conserve land and reduce building costs. 
Figure 4-7. Hanford Central Waste Complex Master Plan.

Figure 4-8. Hanford Lentral Waste Complex-Utilities Master Plan.

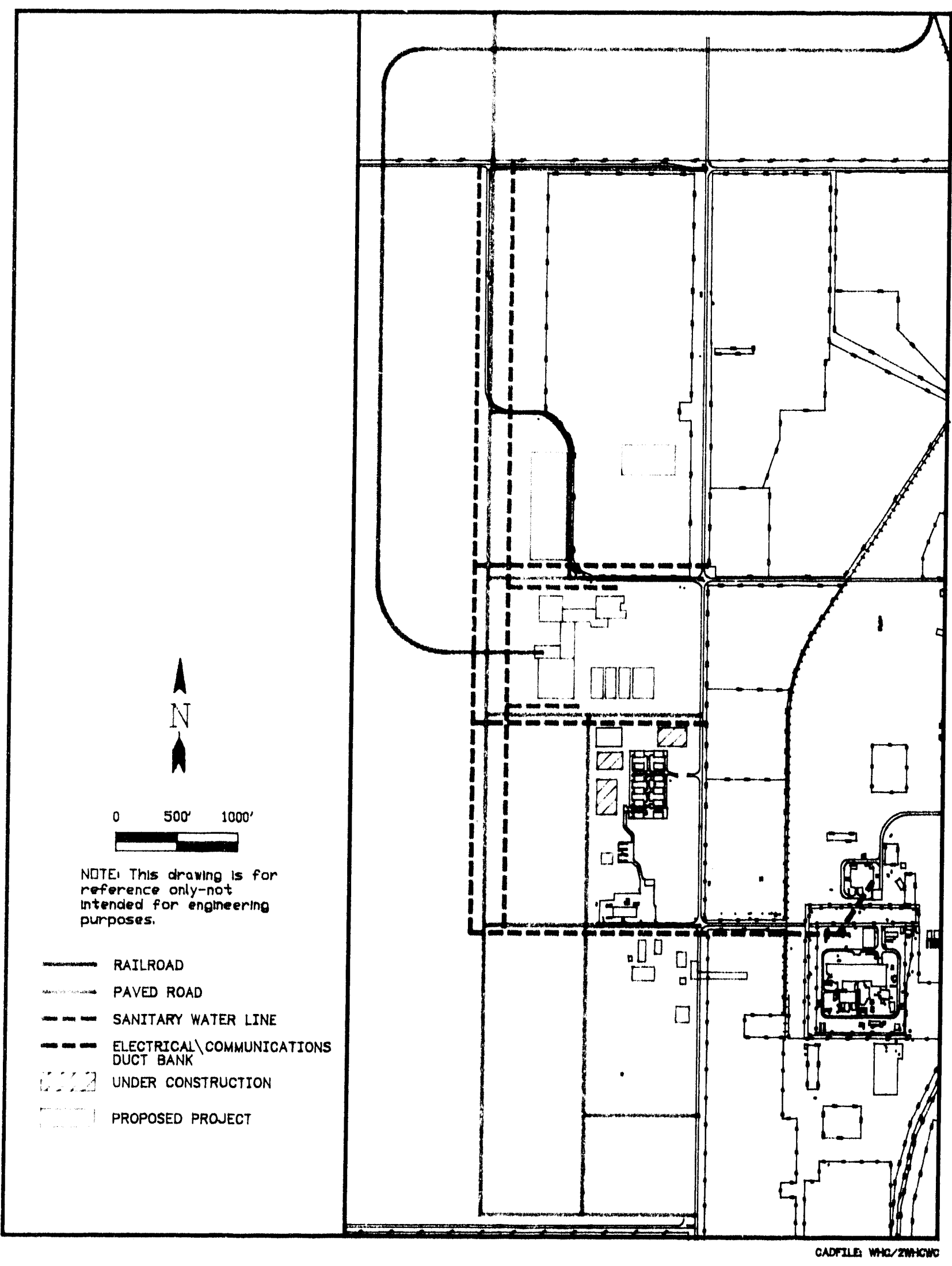


Figure 4-9. 200 Areas Master Plan.

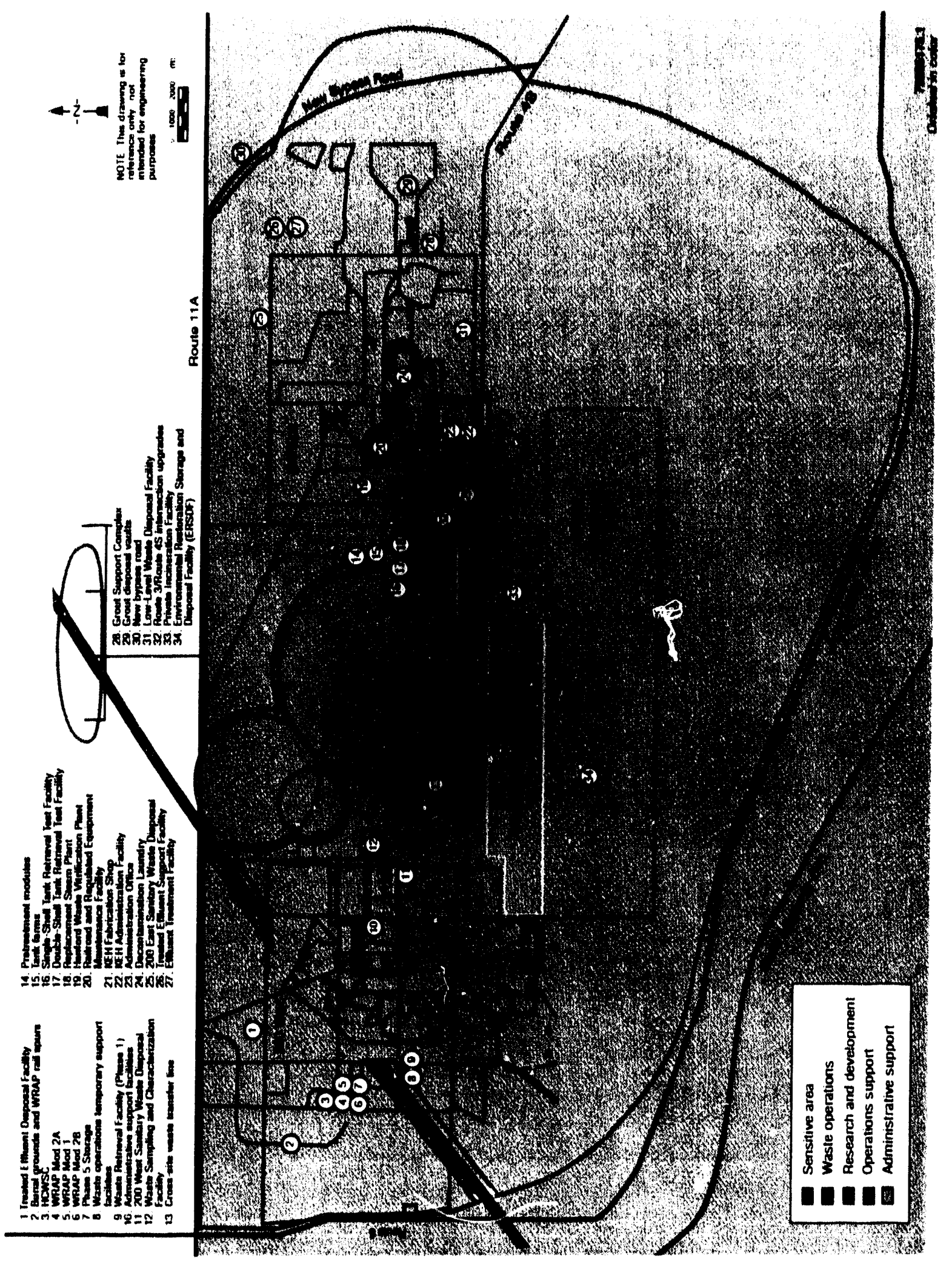




\subsubsection{Site Development Standards}

The following Site development standards are proposed.

- To the extent possible, construction restrictions requested by PNL in the vicinity of the 622 Building complex will be honored (see Appendix D). Development proposals with significant advantages for siting within these areas will be evaluated on a case-by-case basis. If development is required within the requested construction restriction areas, ccordination with PNL will be mandatory to minimize impacts.

- Siting of potentially hazardous facilities will incorporate appropriate buffer zones.

- Facility complexes should be developed to cluster programmatic activities. Parking should be kept to the outside perimeter of the clusters.

- Pedestrian and bicycle pathways should be provided between complexes.

- All designs should emphasize ease of access.

- Utility corridors along roadways should be reserved for main trunk line extensions.

\subsubsection{Setback Standards}

The following setbacks will be used.

- Buildings should be set back $91.44 \mathrm{~m}(300 \mathrm{ft}$ ) from Route 3, Route 4S, and Route 11A.

- Buildings should be set back at least $30.48 \mathrm{~m}(100 \mathrm{ft})$ from centerline of any new roads, depending on type of use.

- Buildings should be set back $15.24 \mathrm{~m}(50 \mathrm{ft})$ from centerline of all other roads.

\subsubsection{Landscaping Standards}

The following landscaping standirds are proposed.

- Landscaping should be used near facilities and clusters.

- Trees, shrubs, hedges, and landform should be used to reduce wind impacts to structures.

- Plant material should be used to reduce wind erosion and storm runoff. 


\subsubsection{Energy Conservation Standards}

The following energy conservation standards will be used:

- Architect's and Engineer's Guide to Energy Conservation in Existing Buildings, Vols. 1 and 2 (DOE/RL/01830P-H4), April 1990.

- Code of Federal Regulations, Title 10, Part 435, Energy Conservation Voluntary Performance Standards for New Buildings; Mandatory for Federal Buildings; Subpart A - Voluntary Performance Standards for New Commercial and Multi-Family High Rise Residential Buildings; Mandatory for Federal Buildings (10 CFR 435).

- Code of Federal Regulations, Title 10, Part 436, Federal Energy Management and Planning Programs; Subpart A - Methodology and Procedures for Life Cycle Cost Analyses (10 CFR 436).

- General Design Criteria, DOE 6430.1A, or DOE 6430.1B when promulgated (DOE/RL 1989).

- The Energy Conservation Manual, when promulgated by DOE Order 6430.1B (DOE/RL 1989).

- Site Development Planning for Energy Management, U.S. Department of Energy, Site Planning Handbook P-3 (DOE/MA-0129), August 1985.

\subsection{NEW INITIATIVES}

The following new initiatives are suggested.

Natural Gas Pipeline. With the 200 Areas serving as the primary area for waste treatment and long-term storage, natural gas may be the preferred option to provide reliable steam supply to the 200 Areas. One option that is being considered is a privately owned and operated gas-fired steam-only plant. The initial phases of a natural gas feasibility study (Weakley 1991) has concluded that gas is a serious option for fueling the 200 Areas steam plant. The study also concluded that rehabilitating existing facilities with gas-fired boilers needs further evaluation.

Hanford Monitored Waste Disposal System Complex. Environmental restoration will require a large capacity facility [occupying approximately $7.8 \mathrm{~km}^{2}\left(3 \mathrm{mi}^{2}\right)$ with an additional $7.8 \mathrm{~km}^{2}\left(3 \mathrm{mi}^{2}\right)$ reserved for expanstion] to treat retrieved contaminated soil and integrate closely with the solid and liquid waste mission for treatment of the liquid leachate resulting from soll treatment. The ERSDF complex, which has a proposed site south of the 200 Areas, will require significant extensions of all infrastructure components.

\section{Remote Solid Material Processing Complex and Multi-Purpose Storage} Complex. Nuclear facilities will need new capabilities to treat and store irradiated fuels. These facilities should or could also contain the capability to treat remote-handled solid waste and decladding and recovery of cesium and strontium. 
Evaporator. A large-volume evaporator will probably be built near the new DSTs, which are being built as part of the Tank Waste Remediation System.

Hazardous and Low-Level Mixed Waste Incineration Facility. This facility, as currently envisioned, would be permitted and operated by a piivate company to provide commercial disposal services. A likely location for this facility would be on the Washington State-leased land west of U.S. Ecology. Close coordination will be required to ensure safe and reliable services and operations.

Analytical Laboratory. The RL is interested in private sector provision of LLW and low-level mixed waste sample analysis capabilities. While most respondents favor placing facilities in or near Richland, the laboratory could be built closer to where the samples are generated. For instance, a facility might be located on the Washington State-leased land. 
DOE/RL-92-29

This page intentionally left blank. 


\subsection{REFERENCES}

10 CFR 435, 1992, "Energy Conservation Voluntary Performance Standards for New Buildings; Mandatory for Federal Buildings; Subpart A - Voluntary Performance Standards for New Commercial and Multi-Family High Rise Residential Buildings; Mandatory for Federal Buildings," Code of Federal Regulations, as amended.

10 CFR 436, 1992, "Federal Energy Management and Planning Programs; Subpart A - Methodology and Procedures for Life Cycle Cost Analyses," Code of Federal Regulations, as amended.

Boomer, K. D., A. L. Boldt, M. D. Britton, L. E. Engelsman, J. D. Galbraith, J. S. Garfield, K. A. Giese, C. E. Golberg, B. A. Higley, K. J. Hull, L. J. Johnson, R. Knight, J. S. Layman, R. S. Marusich, R. J. Parazin, M. G. Piepho, E. J. Siaathaug, T. L. Waldo, and C. E. Worcester, 1991, Systems Engineering Study for the Closure of Single-Shell Tanks, WHC-EP-0405 Draft A, 6 vols., Westinghouse Hanford Company, Richland, Washington.

Comprehensive Environmental Response, Compensation, and Liability Act of 1980, as amended, 42 USC 7401, et seq.

Cushing, C. E., 1991, Hanford Site NEPA Characterization, PNL-6415, Rev. 4 Pacific Northwest Laboratory, Richland, Washington.

DOE, 1987, Final Environmental Impact Statement, Disposal of Hanford Defense High-Level, Transuranic and Tank Waste, Hanford Site, Richland, Washington, DOE/EIS-0113, 5 vols., U.S. Department of Energy, Washington, D.C.

DOE, 1988, "Final Environmental Impact Statement for the Disposal of Hanford Defense High-Leve1, Transuranic, and Tank Wastes, Hanford Site, Richland, Washington; Record of Decision," Federal Register, Vol. 53, No. 72, pp. 12449-12453, U.S. Department of Energy, Washington, D.C.

DOE, 1989, General Design Criteria, DOE Order 6430.1A, U.S. Department of Energy, Washington, D.C.

DOE, 1991a, Site Development Planning, DOE Order 4320.1B, U.S. Department of Energy, Washington, D.C.

DOE, 1991b, Unreviewed Safety Questions, DOE Order 5480.21, U.S. Department of Energy, Washington, D.C.

DOE-MA, 198.5, Site Development Planning for Energy Management, Site Planning Handbook, DOE/MA-0129, U.S. Department of Energy, Washington, D.C.

DOE-RL, 1989, General Design Criteria, DOE/RL 6430.1A, U.S. Department of Energy, Richland Field Office, Richland, Washington. 
DOE-RL, 1989, Hanford Site Strategic Facilities Plan, DOE/RL-89-01, U.S. Department of Energy-Richland Operations Office, Richland, Washington.

DOE-RL, 1990, Architects and Engineer's Guide to Energy Conservation in Existing Buildings, vols. 1 and 2, DOE/RL-01830P-H4, U.S. Department of Energy Field Office, Richland, Richland, Washington.

DOE-RL, 1990a, Hanford Site Development P7an, DOE/RL-89-15, U.S. Department of Energy Field Office, Richland, Richland, Washington.

DOE-RL, 1990b, Hanford Site Infrastructure P7an, DOE/RL-89-31, U.S. Department of Energy Field Office, Richland, Richland, Washington.

Ecology, EPA, and DOE, 1990, Hanford Federal Facility Agreement and Consent Order, 2 vols., as amended, Washington State Department of Ecology, U.S. Environmental Protection Agency, and U.S. Department of Energy, Olympia, Washington.

EPA, 1989, "National Priorities List for Uncontrolled Hazardous Waste Sites," Federal Register Vol. 54, No. 191, U.S. Environmental Protection Agency, Washington, D.C.

Hathaway, H. B., 1992, Hanford Site Development Plan, DOE/RL-92-20 Draft, U.S. Department of Energy, Richland Field Office, Richland, Washington.

National Environmental Policy Act of 1969, 42 USC 4321 et seq.

Resource Conservation and Recovery Act of 1976, as amended, 42 USC 6901 et seq.

RL, 1990, Site Selection, RL Order 4320.2C, U.S. Department of Energy, Richland Field Office, Richland, Washington.

RL, 1992a, 1992 Hanford Mission Plan, D0E/RL-92-07, U.S. Department of Energy, Richland Field Office, Richland, Washington.

RL, 1992b, Strategic Plan, U.S. Department of Energy, Richland Field Office, Richland, Washington.

Weakley, S. A., 1991, Analysis and Decision Document in Support of Acquisition of Steam Supply for the Hanford 200 Area, PNL-7992, Pacific Northwest Laboratory, Richland, Washington. 


\subsection{BIBLIOGRAPHY}

Chatter, J. C., and N. A. Cadoret, 1990, Archeological Survey of the 200 East and West Areas, Hanford Site, Washington, PNL-7264, Pacific Northwest Laboratory, Richland, Washington.

Daly, K. S., S. W. Seiler, and J. C. Hail, 1991, Hanford 300 Area Development Plan, DOE/RL-91-09, U.S. Department of Energy, Richland Field Office, Richland, Washington.

Davis, J. D., 1992, Project W-O49H Treated Effluent Disposal Alternatives Engineering Study, WHC-SD-W-049H-ES-003, Westinghouse Hanford Company, Richland, Washington.

PNL, 1991, Pacific Northwest Laboratory Institutional Plan FY 1992-1997, Pacific Northwest Laboratory, Richland, Washington.

Roecker, J., 1992, Letter 9158421R2 to J. Anttonen (RL) transmitting "Draft Tank Waste Remediation System Decision Plan, Rev. OB," Westinghouse Hanford Company, Richland, Washington. 


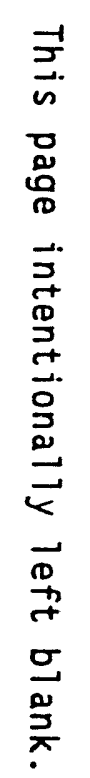

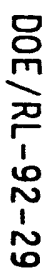

- 
DOE/RL-92-29

APPENDIX A

200 AREAS FACILITIES AND GENERAL LAYOUT

A-1 
DOE/RL-92-29

This page intentionally left blank. 
Table A-1. 200 East Area Buildings Over 1,000 $\mathrm{ft}^{2}$. (sheet 1 of 4)

\begin{tabular}{|c|c|c|c|c|}
\hline $\begin{array}{l}\text { Building } \\
\text { number }\end{array}$ & Building name & size $\left(f t^{2}\right)$ & Contractor & $\begin{array}{l}\text { Location on } \\
\text { map }\end{array}$ \\
\hline $202 \mathrm{~A}$ & PUREX CANYON AND SERVICE FACILITYY & 188,890 & WHC & H7 \\
\hline 204AR & WASTE UNLOADING FACILITY & 2,560 & WHC & G7 \\
\hline $206 \mathrm{~A}$ & $\begin{array}{l}\text { VACUUM ACID FRACTIONATOR BUILDING, ABOVE } \\
\text { GRADE }\end{array}$ & 1,265 & WHC & 47 \\
\hline $209 E$ & CRITICAL MASS LABORATORY & 7,979 & WHC & F5 \\
\hline $2101 M$ & SPARE PARTS WAREHOUSE, OFFICE BUILDING & 169,320 & WHC & H3 \\
\hline $211 \mathrm{~A}$ & CHEMICAL MAKEUP TANK FARM, PUMP HOUSE & 2,916 & WHC & G6 \\
\hline $212 B$ & FISSION PROOUCTS LOADOUT STATION & 4,389 & WHC & E3 \\
\hline $221 B$ & PROCESS TREATMENT BUILDING, CANYON & 83,500 & WHC & E3 \\
\hline $222 B$ & OFFICE BUILDING & 7,336 & WHC & E3 \\
\hline 22448 & MULTICRAFT SHOP & 3,000 & KEH & E3 \\
\hline .22478 & IRONWORKER'S SHOP & 1,200 & KEH & E3 \\
\hline $224 \mathrm{~B}$ & STORAGE BUILDING & 32,300 & WHC & E3 \\
\hline 2258 & $\begin{array}{l}\text { HIGH-LEVEL WASTE PACKAGE ENCAPSULATION } \\
\text { FACILITY }\end{array}$ & 20,463 & WHC & E3 \\
\hline $225 B C$ & ENCAPSULATION COMPRESSOR FACILITY & 1,008 & WHC & E3 \\
\hline 225BE & ENCAPSULATION REPAIR SHOP & 3,200 & WHC & E3 \\
\hline $2418 Y$ & WASTE DISPOSAL TANK FARM & 1,028 & WHC & 83 \\
\hline $242 A$ & EVAPORATOR & 8,360 & HHC & G7 \\
\hline $242 B$ & RADIOACTIVE PARTICLE RESEARCH LABORATORY & 2,713 & PNL & $C_{4}$ \\
\hline 244AR & SLUDGE VAULT STORAGE AND PROCESSING & 3,735 & WHC & F7 \\
\hline $2704 \mathrm{C}$ & OFFICE ADMINISTRATION AND GATE HOUSE & 1,025 & WHC & E5 \\
\hline $2707 E$ & CHANGE HOUSE & 3,306 & WHC & G3 \\
\hline $2711 E$ & 2E GARAGE & 6,300 & WHC & Q3 \\
\hline $2713 E$ & OFFICE ADMINISTRATION BUILDING & 4,158 & WHC & H3 \\
\hline $2714 A$ & DRY CHEMICAL WAREHOUSE & 2,250 & WHC & G6 \\
\hline 2715EB & CARPENTER STORAGE & 1,760 & WHC & H3 \\
\hline 2715EC & PAINT SHOP & 1,000 & WHC & $\mathrm{H3}$ \\
\hline $2718 E$ & CRITICAL MASS STORAGE & 1,664 & WHC & F5 \\
\hline 2719EA & MEDICAL AID STATION & 1,500 & HHC & 63 \\
\hline 2718 & SERVICE AMD OFFICE BUILDING & 30,700 & WHC & G3 \\
\hline $271 C R$ & SERVICE AND OFFICE BUILDING & 3,197 & WHC & E7 \\
\hline $2721 E$ & $\begin{array}{l}\text { PATROL HEADQUARTERS - CENTRAL ALARM } \\
\text { FACILITY }\end{array}$ & 9,114 & WHC & G1 \\
\hline 2721EA & HELICOPTER SUPPORT FACILITY & 25,600 & HHC & G2 \\
\hline 2722E & OFFICE BUILDING & 1,200 & WHC & H3 \\
\hline $2727 E$ & SAFEGUARDS AND SECURITY OFFICES & 19,000 & WHC & 61 \\
\hline
\end{tabular}


Table A-1. 200 East Area Buildings Over 1,000 $\mathrm{ft}^{2}$. (sheet 2 of 4)

\begin{tabular}{|c|c|c|c|c|}
\hline $\begin{array}{l}\text { Building } \\
\text { number }\end{array}$ & Building name & size $\left(f t^{2}\right)$ & Contractor & $\begin{array}{l}\text { Location on } \\
\text { map }\end{array}$ \\
\hline $272 B$ & ELECTRICAL MAINTENANCE SHOP BUILDING & 1,760 & WHC & E3 \\
\hline $272 B C$ & $\begin{array}{l}\text { PIPE AND ELECTRICAL CONSTRUCTION SHOP AND } \\
\text { STORAGE }\end{array}$ & 3,200 & WHC & F3 \\
\hline $272 E$ & FABRICATION, MOCKUP SHOP BUILDING & 17,250 & WHC & H3 \\
\hline $273 E$ & MATERIAL STORAGE & 6,000 & HHC & 63 \\
\hline $274 E$ & LANDLORD AND MAINTENANCE SHOP & 3,792 & HHC & H3 \\
\hline $2750 E$ & $\begin{array}{l}\text { WASTE MANAGEMENT SURV. AND OPERATING } \\
\text { FACILITY }\end{array}$ & 96,000 & WHC & 13 \\
\hline $2751 E$ & OFFICE FACILITY & 15,000 & WHC & 13 \\
\hline $2752 E$ & 200 EAST OFFICE & 15,000 & WHC & 13 \\
\hline $2753 E$ & 200 EAST OFFICE & 15,000 & WHC & 13 \\
\hline $275 E$ & CARPENTER SHOP BUILDING & 3,792 & WHC & H3 \\
\hline 275EA & $\begin{array}{l}\text { WAREHOUSE ESSENTIAL MATERIALS, NUMBER OF } \\
\text { PUREX }\end{array}$ & 36,000 & WHC & H3 \\
\hline $276 A$ & COLD SOLVENT STORAGE BUILDING, R CELLL & 1,500 & WHC & H6 \\
\hline $276 C$ & SOLVENT HANOLING BUILDING & 2,299 & WHC & E5 \\
\hline $282 E$ & PUMP HOUSE AND RESERVOIR & 1,434 & WHC & H4 \\
\hline $283 E$ & WATER FILTRATION PLANT & 7,504 & WHC & H4 \\
\hline $284 E$ & POWERHOUSE AND STEAM PLANT & 33,815 & WHC & H4 \\
\hline $291 B D$ & AIR CONTROL HOUSE & 1,092 & WHC & E3 \\
\hline M0012 & MOBILE OFFICE a GROUT & 1,584 & WHC & H7 \\
\hline MO021 & MOBILE OFFICE O 2101M & 1,584 & WHC & 13 \\
\hline M0023 & MOBILE OFFICE D 202A & 5,544 & WHC & G6 \\
\hline M0029 & MOBILE OFFICE D $271 \mathrm{~B}$ & $2, \pi 72$ & WHC & E3 \\
\hline M0035 & TRAINING FACILITY a 202A & 1,344 & WHC & 66 \\
\hline M0040 & MOBILE OFFICE O $284 E$ & 2,772 & WHC & H4 \\
\hline M0041 & MOBILE OFFICE O 2436 & 1,848 & WHC & 68 \\
\hline M0042 & MOBILE OFFICE Q 275OE & 2,772 & WHC & 13 \\
\hline 10043 & MOBILE OFFICE (DOSIMETRY) a 2750 & 3,696 & HHC & 13 \\
\hline M0047 & MOBILE OFFICE D $2101 M$ & 12,012 & WHC & H3 \\
\hline M0048 & 200 AREA CENTRAL SIGN SHOP & 1,848 & WHC & H3 \\
\hline Moin4 & MOBILE OFFICE O $2719 E$ & 1,344 & WHC & 63 \\
\hline M0108 & PREVIOUSLY CAI.LED TRL. 57B & 1.680 & KEH & 64 \\
\hline M0109 & OFFICE/CHANGE/TRAINING TRAILER จ 224B & 1,848 & WHC & E3 \\
\hline M0227 & ENGINEERING OFFICE D UCA & 1,848 & KEH & 12 \\
\hline M0232 & MOBILE OFFICE a 2718 & 1,848 & WHC & E3 \\
\hline M0234 & MOBILE OFFICE D $2750 E$ & 9,240 & WHC & 13 \\
\hline
\end{tabular}


Table A-1. 200 East Area Buildings Over 1,000 $\mathrm{ft}^{2}$. (sheet 3 of 4)

\begin{tabular}{|c|c|c|c|c|}
\hline $\begin{array}{l}\text { Building } \\
\text { number }\end{array}$ & Building name & size $\left(f t^{2}\right)$ & Contractor & $\begin{array}{c}\text { Location on } \\
\text { map }\end{array}$ \\
\hline MO245 & MOBILE OFFICE D GATE 815 & 1,848 & WHC & 13 \\
\hline M0246 & MOBILE OFFICE a GATE 815 & 1,848 & WHC & 13 \\
\hline M0247 & MOBILE OFFICE D GATE 815 & 1,848 & WHC & 13 \\
\hline M0248 & MOBILE OFFICE D GATE 815 & 1,848 & WHC & 13 \\
\hline M0251 & MOBILE OFFICE O GATE 850 & 1,848 & WHC & H3 \\
\hline M0252 & MOBILE OFFICE Q GATE 850 & 1,848 & WHC & H3 \\
\hline M0253 & MOBILE OFFICE O GATE 850 & 1,848 & WHC & H3 \\
\hline M0256 & MOBILE OFFICE E/O 27I1E & 1,848 & WHC & a3 \\
\hline M0257 & MOBILE OFFICE E/O 2711E & 1,848 & WHC & 63 \\
\hline M0266 & MOBILE OFFICE จ 272AH & 1,848 & WHC & G7 \\
\hline M0267 & MOBILE OFFICE \ 272AW & 1,848 & WHC & G7 \\
\hline M0268 & MOBILE OFFICE จ ZTZAN & 1,848 & WHC & G7 \\
\hline M0273 & MOBILE OFFICE a PUREX & 9,240 & WHC & G6 \\
\hline M0304 & MOBILE OFFICE Q EFSO PIPEYARD & 1,296 & WHC & $\begin{array}{c}\text { North of } \\
200 \text { East } \\
\text { Area }\end{array}$ \\
\hline$M 0347$ & MOBILE OFFICE O $202 A$ (ATTACHED TO MO948) & 1,296 & WHC & G6 \\
\hline M0354 & MOBILE OFFICE D $2400 E$ & 1,296 & WHC & G5 \\
\hline M0355 & MOBILE OFFICE a 2021 (ATTACHED TO MO542) & 1,296 & WHC & G6 \\
\hline M0384 & MOBILE OFFICE a $2703 E$ & 1,848 & WHC & G3 \\
\hline M0386 & MOBILE OFFICE D DMRHF & 1,848 & WHC & G5 \\
\hline M0388 & SRT HQ TRAILER O 2721EA & 1,456 & WHC & G2 \\
\hline M0392 & MOBILE OFFICE @ 2436 & 1,848 & HHC & G8 \\
\hline M0393 & MOBILE OFFICE D 272AH TANK FARMS & 1,200 & WHC & 67 \\
\hline $\mathrm{MO400}$ & MOBILE OFFICE O 2718 & 4,620 & WHC & E3 \\
\hline MO405 & MOBILE OFFICE O PUREX & 13,860 & WHC & G6 \\
\hline M0407 & MOBILE OFFICE $2101 \mathrm{M}$ & 4,620 & WHC & 13 \\
\hline $\mathrm{MO408}$ & MOBILE OFFICE D 2718 & 2,772 & WHC & E3 \\
\hline M0409 & ANALYTICAL LAB TRAILER O PUREX & 3,696 & HHC & G7 \\
\hline M0410 & MOBILE OFFICE D $271 B$ & 2,772 & HHC & E3 \\
\hline MO4 13 & MOBILE OFFICE D $2750 E$ & 7,392 & WHC & 13 \\
\hline MO4 14 & MOBILE OFFICE O OLD 2704E SITE & 11,088 & WHC & G3 \\
\hline$M 0542$ & MOBILE OFFICE a 2024 (ATT'D/ID'D MO355) & 1.296 & WHC & G6 \\
\hline M0543 & CHANGEROOM/LUNCHROOM TRAILER O $2704 C$ & 1,296 & WHC & $\mathbf{E 5}$ \\
\hline M0551 & PREVIOUSLY TRL. 6 & 1,344 & KEH & G4 \\
\hline M0552 & PREVIOUSLY TRL. 105 & 1,344 & KEH & G4 \\
\hline M0553 & PREVIOUSLY TRL. 57A & 1,680 & KEH & G4 \\
\hline
\end{tabular}


Table A-1. 200 East Area Buildings Over 1,000 $\mathrm{ft}^{2}$. (sheet 4 of 4)

\begin{tabular}{|c|c|c|c|c|}
\hline $\begin{array}{l}\text { Building } \\
\text { number }\end{array}$ & Building name & $\operatorname{size}\left(t t^{2}\right)$ & Contractor & $\begin{array}{c}\text { Location on } \\
\text { map }\end{array}$ \\
\hline M0560 & PROJECT MANAGEMENT D UCA & 1,680 & KEH & 12 \\
\hline M0570 & CONSTRUCTIOH SUPT. TRL. & 1,680 & KEH & F7 \\
\hline M0829 & WELL DRILLERS SUPT. OFFICE & 1.680 & KEH & G4 \\
\hline M0838 & PREVIOUSLY 57B & 1,200 & KEH & G4 \\
\hline M0852 & PREVIOUSLY 2910E & 4,620 & KEH & 64 \\
\hline M0860 & PREVIOUSLY 2910E & 1,680 & KEH & 64 \\
\hline M0863 & OFFICE/LUNCHROOM TRAILER O 2258 & 1,584 & WHC & E3 \\
\hline M0901 & PREVIOUSLY 2911E & 1,680 & KEH & Q4 \\
\hline M0919 & MOBILE OFFICE O $241 A Y$ (EVAP SUPP) & 1,344 & WHC & F7 \\
\hline M0921 & MOBILE OFFICE O $2911 E$ & 1,344 & KEH & G4 \\
\hline M0922 & OFFICE/CHANGE TRAILER O 2703E & 1,344 & WHC & G3 \\
\hline M0927 & MOBILE OFFICE Q GROUT & 1,344 & WHC & $H 7$ \\
\hline M0931 & GRAPHICS TRLR D 284E (ATT M0203) & 1.440 & WHC & 64 \\
\hline M0932 & PREVIOUSLY $2911 E$ & 1,680 & KEH & 64 \\
\hline M0946 & MOBILE OFFICE จ PUREX & 1,200 & WHC & 66 \\
\hline M0948 & MOBILE OFFICE D $202 A$ (ATT'D/ID'D AS MO347) & 1,200 & WHC & G6 \\
\hline M0966 & ALL CRAFT LUNCH TRL. O B-PLANT & 1,200 & KEH & F3 \\
\hline M0991 & ENGINEERING OFFICES Q UCA & 1,848 & KEH & $\sqrt{2}$ \\
\hline M0994 & ENGINEERING OFFICES O UCA & 1,344 & KEH & 12 \\
\hline M0995 & MOBILE OFFICE O 2718 & 1,344 & WHC & E3 \\
\hline M0996 & MOBILE OFFICE O 27ZAH & 1,344 & WHC & 67 \\
\hline
\end{tabular}

KEH = Kaiser Engineers Hanford.

PNL = Pacific Morthwest Laboratory.

HHC = Westinghouse Hanford Company. 
Table A-2. 200 Area Corridor Buildings Over 1,000 ft ${ }^{2}$.

\begin{tabular}{|c|c|c|c|c|}
\hline $\begin{array}{l}\text { Building } \\
\text { number }\end{array}$ & Building name & $\operatorname{size}\left(f t^{2}\right)$ & Contractor & $\begin{array}{l}\text { Location on } \\
\text { map }\end{array}$ \\
\hline $212 N$ & STORAGE BUILOING & 5,979 & WHC & $\begin{array}{l}\text { North of } \\
\text { corridor }\end{array}$ \\
\hline $212 P$ & $\begin{array}{l}\text { ELECTRICAL STORAGE AND } \\
\text { TRANSFORMER SHOP }\end{array}$ & 5,979 & WHC & $\begin{array}{l}\text { North of } \\
\text { corridor }\end{array}$ \\
\hline $212 R$ & STORAGE BUILOING & 5,979 & WHC & $\begin{array}{l}\text { North of } \\
\text { corridor }\end{array}$ \\
\hline $251 \mathrm{~W}$ & $\begin{array}{l}\text { PRIMARY } 230 \mathrm{kV} \text { SWITCHING STATION, } \\
\text { NO. OF } 200 \mathrm{~W}\end{array}$ & 4,177 & WHC & B5 \\
\hline 506 & BY TELEPHONE EXCHANGE & 2,041 & GTEL & 16 \\
\hline 509 & AREA TELEPHONE CENTRAL OFFICE BUILDING & 2,300 & UTC & 16 \\
\hline $609 A$ & FIRE STATION, 200 AREAS & 8,350 & WHC & 16 \\
\hline $609 \mathrm{C}$ & FIRE DEPARTMENT TRAINIMG FACILITY & 2,000 & WHC & 16 \\
\hline 6090 & FIRE OEPARTMENT TRAINING TOWER & 3,000 & WHC & 16 \\
\hline 609E & FIRE STATION STORAGE FACILITYY & 1,800 & HHC & 16 \\
\hline 6096 & FIRE ALARM AND TESTING OFFICE FACILITY & 2,740 & WHC & 16 \\
\hline 616 & $\begin{array}{l}\text { NONRADIOACTIVE HAZARDOUS CHEMICAL WASTE } \\
\text { FACILIITY }\end{array}$ & 7,700 & WHC & 16 \\
\hline $622 \mathrm{C}$ & STORAGE BUILDING & 1,170 & PNL & F3 \\
\hline 6220 & STORAGE BUILDING & 1,013 & PNL & 14 \\
\hline $622 E$ & STORAGE BUILDING & 1,013 & WHC & 54 \\
\hline $622 F$ & FIELD OFFICE BUILDING & 3,300 & PNL & $\mathbf{F 3}$ \\
\hline 6220 & ATMOSPHERE SCIENCE ANMEX & 3,741 & WHC & F3 \\
\hline $622 R$ & METEOROLOGY LABORATORY & 8,960 & PNL. & F3 \\
\hline 6290 & RIGGING SERVICES FACILITY & 8,650 & WHC & 18 \\
\hline MO254 & MOBILE OFFICE $\bigcirc 6220$ & 1,848 & WHC & $\mathbf{F 3}$ \\
\hline M0255 & MOBILE OFFICE $\triangle 622 G$ & 1,848 & WHC & F3 \\
\hline
\end{tabular}

GTEL = General Telephone.

PNL = Pacific Northwest Laboratory.

UTC = Benton County Public Utility District.

WHC = West inghouse Hanford Company. 
Table A-3. 200 West Area Bulldings Over 1,000 $\mathrm{ft}^{2}$. (sheet 1 of 3)

\begin{tabular}{|c|c|c|c|c|}
\hline $\begin{array}{l}\text { Building } \\
\text { number }\end{array}$ & Buflding name & size $\left(t t^{2}\right)$ & Contractor & $\begin{array}{c}\text { Location on } \\
\text { map }\end{array}$ \\
\hline 2025 & REDOX CANYON ANO SERVICE FACILITY & 149,935 & WHC & L6 \\
\hline $221 T$ & PROCESS, CANYON LABORATORY AND OFFICE & 97,711 & WHC & 07 \\
\hline $221 T A$ & VENT FAN HOUSE & 1,291 & WHC & 07 \\
\hline 2210 & U PLANT CANYYON AND SERVICE BUILDING & 83,500 & WHC & 17 \\
\hline 2225 & CONTROL LABORATORY & 60,167 & HHC & M7 \\
\hline 222SA & STANDARDS/PROCESS DEV LABORATORY & 4,500 & WHC & $M 7$ \\
\hline 22258 & FILTER BUILDING & 4,677 & WHC & $M 7$ \\
\hline 2225 & OFFICE AOMINISTRATION BUILOING & 7,336 & WHC & 07 \\
\hline 2220 & OFFICE AND LABORATORY BUILDINO & 7,508 & WHC & 17 \\
\hline $224 T$ & TRANSURANIC STORAGE AND ASSAY FACILITY & 32,300 & WHC & 07 \\
\hline 2240 & CONCENTRATION FACILITY, $\mathrm{NO}_{3}$ PLANT & 32,300 & WHC & 17 \\
\hline 22404 & CALCINATION FACILITY & 10,133 & WHC & 17 \\
\hline $2300 \mathrm{~W}$ & ELECTRICIAN'S SHOP & 1,600 & KEH & 66 \\
\hline $2301 W$ & IRONWORKER'S SHOP & 1.670 & KEH & 66 \\
\hline $2304 \mathrm{H}$ & PIPEFITTER'S SHOP & 1,200 & KEH & Q6 \\
\hline 2312 & MATERIALS ENGINEERING LABORATORY & 38,121 & WHC & Q4 \\
\hline 2322 & WASTE INCINERATOR FACILITY & 2,090 & WHC & $\mathrm{H4}$ \\
\hline 2335 & CONCENTRATION FACILITY & 2,100 & WHC & L6 \\
\hline $234-52$ & PLUTONIUM FINISHING PLANT & 212,477 & WHC & 64 \\
\hline 23428 & WASTE MATERIAL STORAGE BUILDING & 1,078 & WHC & H4 \\
\hline 2362 & PLUTONIUM RECLAMATION FACILITY & 20,430 & WHC & H4 \\
\hline 2402WG & RMW STORAGE FACILITY & 4,000 & WHC & $\mathbf{F 2}$ \\
\hline $2402 W H$ & RMH STORAGE FACILITY UB & 4,000 & WHC & $\mathbf{F 2}$ \\
\hline $2402 W I$ & RMW STORAGE FACILITY *O & 4,000 & WHC & 52 \\
\hline $2402 \mathrm{WJ}$ & RMW STORAGE FACILITY $\# 10$ & 4,000 & WHC & $F 2$ \\
\hline $2402 W K$ & RMH STORAGE FACILITY "EII & 4,000 & WHC & $\mathbf{F 2}$ \\
\hline $2402 \mathrm{HL}$ & RMH STORAGE FACILITY \#12 & 4,000 & WHC & $\mathbf{F 2}$ \\
\hline $2403 \mathrm{WA}$ & RMW STORAGE FACILITY & 34,000 & WHC & $\mathbf{F 2}$ \\
\hline $2403 W B$ & RMU STORAGE FACILITY & 34,000 & WHC & $\mathbf{F 3}$ \\
\hline $2403 W C$ & RMU STORAGE FACILITY & 34,000 & WHC & $\mathbf{F 2}$ \\
\hline 240310 & RMH STORAGE FACILITY & 55,250 & WHC & $F 2$ \\
\hline 24IWR & $\begin{array}{l}\text { VAULT THORIUM STORAGE, U AREA DIVERTER } \\
\text { STATION }\end{array}$ & 10,235 & HHC & H7 \\
\hline 2412 & TANK FARM WASTE DISPOSAL BUILDING & 2,340 & WHC & H4 \\
\hline 2422 & WASTE TREATMENT FACILITY & 1,050 & WHC & G4 \\
\hline $2701 W A$ & GATE HOUSE AND PATROL HEADQUARTERS & 2,023 & WHC & F9 \\
\hline $27012 A$ & CENTRAL ALARM STATION FACILITY & 2,256 & WHC & 64 \\
\hline 27045 & OFFICE BUILDING & 8,174 & WHC & M6 \\
\hline $2704 \mathrm{H}$ & OFFICE BUILDING & 6,457 & WHC & F8 \\
\hline 27042 & OFFICE ADMINISTRATION BUILDING & 3,911 & WHC & G4 \\
\hline
\end{tabular}


Table A-3. 200 West Area Buildings Over 1,000 $\mathrm{ft}^{2}$. (sheet 2 of 3)

\begin{tabular}{|c|c|c|c|c|}
\hline $\begin{array}{l}\text { Building } \\
\text { number }\end{array}$ & Bullding name & size $\left(f t^{2}\right)$ & Contractor & $\begin{array}{l}\text { Location on } \\
\text { Map }\end{array}$ \\
\hline 27061 & EQUIPMENT DECONTAMINATION BUILDINO & 3,330 & WHC & 07 \\
\hline $27075 x$ & CHANGE HOUSE & 1,440 & WHC & K5 \\
\hline $270 \pi$ & CHANGE HOUSE & 2,616 & WHC & 58 \\
\hline $2709 \mathrm{~W}$ & OFFICE BUILOINO & 1,816 & WHC & F9 \\
\hline 2702 & PFP OPERATIONS AND SUPPORT FACILITY & 13,000 & WHC & G4 \\
\hline $2713 \mathrm{H}$ & GARAOE & 4,160 & WHC & F8 \\
\hline 2713 WB & $\begin{array}{l}\text { REQULATED GARAGE AND HEAVY EQUIPMENT } \\
\text { REPAIR }\end{array}$ & 6,150 & WHC & F6 \\
\hline 27140 & WAREHOUSE & 4,320 & WHC & 17 \\
\hline 27168 & LABORATORY STORAGE & 1,500 & WHC & M7 \\
\hline 2719WA & FIRST AID STATION AND OFFICES & 2,545 & WHC & $\mathbf{F 8}$ \\
\hline $271 T$ & OFFICE AND SERVICE BUILOING & 30,700 & WHC & 07 \\
\hline 2710 & PLUTONIUM STORAGE & 30,700 & WHC & 17 \\
\hline $2720 \mathrm{~W}$ & PATROL HEADOUARTERS AHO CHANGEROOM & 2,216 & WHC & F9 \\
\hline $2722 W$ & WELDING LABORATORY BUILDING & 1,474 & WHC & 58 \\
\hline $2723 W$ & MASK LAUNORY AND OFFICE BUILDINO & 4,519 & WHC & F8 \\
\hline $2724 \mathrm{~W}$ & LAUNDRY FACILITY & 14,657 & WHC & 78 \\
\hline 272464 & LAUNORY STORAGE FACILITY & 3,120 & WHC & $\$ 8$ \\
\hline 272448 & STORAGE BUILDINO & 1,600 & WHC & 18 \\
\hline 27260 & PROPANE GAS STORAGE FACILITY & 1,080 & WHC & 17 \\
\hline $2727 N$ & SOOIUN STORAGE BUILOINO & 2,700 & WHC & 16 \\
\hline 27284 & DIMENSIONAL INSPECTION BUILDING & 1,000 & WHC & $\$ 8$ \\
\hline 27292 & STORAGE BUILDINO & 1,600 & WHC & $\mathrm{H4}$ \\
\hline 2725 & MAINTENANCE SHOP & 4,527 & WHC & K5 \\
\hline 2724 & MAINTENANCE SHOP BUILOING & 2,368 & WHC & 17 \\
\hline $272 H$ & MACHINE SHOP BUILDING & 16,651 & WHC & 58 \\
\hline $272 W A$ & TANK FARM SUPPORT FACILITY & 18,700 & WHC & 62 \\
\hline 27342 & GAS CYLIMDER STORAGE FACILITY & 1,163 & WHC & H4 \\
\hline 27362 & PLUTONIUM STORAGE VAULT & 3,705 & WHC & 64 \\
\hline 273628 & PLUTONIUM STORAGE SUPPORT FACILITY & 11,980 & WHC & $\mathrm{H4}$ \\
\hline $273 \mathrm{~W}$ & MATERIAL STORAGE & 6,000 & WHC & $\mathbf{F B}$ \\
\hline $274 \mathrm{~W}$ & OFFICE BUILDING & 3,815 & WHC & 58 \\
\hline 275UR & CHEMICAL STORAGE WAREHOUSE & 2,880 & WHC & 17 \\
\hline $275 \mathrm{H}$ & HEAVY EQUIPMENT SHOP & 3,792 & WHC & 18 \\
\hline 2765 & COLD SOLVENT STORAGE AND MAKEUP BUILDING & 2,650 & WHC & 16 \\
\hline $276 U$ & SOLVENT RECOVERY FACILITY & 3,725 & WHC & 17 \\
\hline $27 \pi$ & FABRICATION SHOP & 29,170 & WHC & F8 \\
\hline $282 W$ & RESERVOIR PUMP HOUSE & 1.434 & WHC & $\$ 7$ \\
\hline $283 W$ & WATER FILTRATION PLANT & 8,293 & WHC & F7 \\
\hline $284 \mathrm{~W}$ & PONERHOUSE STEAM PLANT & 27,132 & WHC & F7 \\
\hline
\end{tabular}


Table A-3. 200 West Area Buildings Over 1,000 $\mathrm{ft}^{2}$. (sheet 3 of 3)

\begin{tabular}{|c|c|c|c|c|}
\hline $\begin{array}{l}\text { Bullding } \\
\text { number }\end{array}$ & Building nam & size $\left(f t^{2}\right)$ & Contractor & $\underset{\text { Lap }}{\text { Location on }}$ \\
\hline 2912 & EXHAUST AIR FILTER STACK BUILDING & 13,680 & WHC & $\mathrm{H4}$ \\
\hline 2935 & ACIO RECOVERY ANO GAS TREATMENT BUILDING & 1,361 & WHC & $\llcorner 7$ \\
\hline M0011 & 20OW PATROL HO 234.52 & 1,584 & WHC & 65 \\
\hline M0027 & MOBILE OFFICE \& $272 S$ & 1,848 & WHC & $\sqrt{5}$ \\
\hline M0028 & RAD WORKER TRAININO TRAILER O 27045 & $2, \pi 72$ & WHC & M6 \\
\hline M0031 & MOBILE OFFICE $\bigcirc 234-52$ & 2,772 & WHC & 04 \\
\hline M0032 & MOBILE OFFICE $\bigcirc 234-52$ & $2, \pi 72$ & WHC & 64 \\
\hline M0037 & MOBILE OFFICE D $222 S$ & 5,544 & WHC & M6 \\
\hline M0039 & MOBILE OFFICE O $2704 \mathrm{~S}$ & $2, \pi 72$ & WHC & M6 \\
\hline M0056 & MOBILE OFFICE $\bigcirc 2704 \mathrm{H}$ & 1,584 & WHC & 58 \\
\hline M0107 & MOBILE OFFICE D $224 \mathrm{U}$ & 1,584 & WHC & 17 \\
\hline M0235 & MOBILE OFFICE O $2722 \mathrm{~W}$ & 1,848 & WHC & 58 \\
\hline M0240 & CHANGEROOM/OFFICE TRAILER O 284W & 1,848 & WHC & F7 \\
\hline$M 0244$ & 200W PATROL CHANGE TRAILER a 234.52 & 2,772 & WHC & 65 \\
\hline M0249 & MOBILE OFFICE O 234-52 & 1,848 & WHC & 65 \\
\hline M0250 & MOBILE OFFICE O $234-52$ & 1,848 & WHC & 65 \\
\hline M0346 & MOBILE OFFICE O $222 S$ & 1,200 & WHC & M6 \\
\hline M0406 & CHANGE/LUNCHROOM TRAILER O 2724WB & 2,772 & WHC & F8 \\
\hline M0412 & MASK CLEANINO STATION O $2724 \mathrm{~W}$ & 5,544 & WHC & F8 \\
\hline MO419 & MOBILE OFFICE O 2240 & 1,848 & WHC & 17 \\
\hline M0556 & PREVIOUSLY TRL. W-5 & 1,200 & KEH & 66 \\
\hline Mor20 & MOSILE OFFICE O 271-U & 1,848 & WHC & 17 \\
\hline M0841 & PREVIOUSLY N-6 & 1,200 & KEH & G6 \\
\hline M0909 & MOBILE OFFICE Q 222T & 1,344 & WHC & 07 \\
\hline M0924 & MOBILE OFFICE O 2025 & 1,344 & WHC & M6 \\
\hline M0936 & MOBILE OFFICE Q $222 \mathrm{~S}$ & 1,584 & HHC & M6 \\
\hline M0947 & MOBILE OFFICE O 27045 & 1,200 & WHC & M6 \\
\hline M0997 & SECURITY CHECKPOINT TRAILER \& 27042 & 1,344 & HHC & G4 \\
\hline
\end{tabular}

KEH = Kaiser Engineers Hanford

WHC = Hestinghouse Hanford Company 
DOE/RL-92-29

APPENDIX B

PROJECTED POPULATIONS BY AREA

B-1 
DOE/RL-92-29

This page intentionally left blank.

B-2 
Table B-1. 200 East Area Projected Population (as of September 1992).

\begin{tabular}{|c|c|c|c|c|c|c|c|}
\hline \multirow{3}{*}{ Organization } & \multirow{3}{*}{$\begin{array}{l}\text { Type of } \\
\text { personne } 1\end{array}$} & \multicolumn{6}{|c|}{ Fiscal year } \\
\hline & & \multirow{2}{*}{\begin{tabular}{c|} 
Actual \\
1992 \\
\end{tabular}} & \multicolumn{5}{|c|}{ Projected } \\
\hline & & & 1993 & 1994 & 1995 & 1996 & 1997 \\
\hline \multirow{2}{*}{$\begin{array}{l}\text { Hanford } \\
\text { Environmental } \\
\text { Health } \\
\text { Foundation }\end{array}$} & $\begin{array}{l}\text { Office, } \\
\text { bargair }\end{array}$ & $\begin{array}{l}2 \\
--\end{array}$ & $\begin{array}{c}2 \\
--\end{array}$ & $\begin{array}{c}3 \\
--\end{array}$ & $\begin{array}{c}4 \\
--\end{array}$ & $\begin{array}{c}4 \\
--\end{array}$ & $\begin{array}{l}4 \\
--\end{array}$ \\
\hline & Troter? & 2 & 2 & 8 & 4 & 4 & 4 \\
\hline \multirow{2}{*}{$\begin{array}{l}\text { Kaiser } \\
\text { Engineers } \\
\text { Hanford }\end{array}$} & $\begin{array}{l}a b \\
n g\end{array}$ & $\begin{array}{l}167 \\
143\end{array}$ & $\begin{array}{l}205 \\
130\end{array}$ & $\begin{array}{l}220 \\
130\end{array}$ & $\begin{array}{l}235 \\
130\end{array}$ & $\begin{array}{l}245 \\
130\end{array}$ & $\begin{array}{l}260 \\
130\end{array}$ \\
\hline & Total & 310 & 335 & (159) & 3. & 375 & 3908 \\
\hline \multirow{2}{*}{$\begin{array}{l}\text { Pacific } \\
\text { Northwest } \\
\text { Laboratory }\end{array}$} & & $\begin{array}{l}-- \\
--\end{array}$ & -- & -- & -- & -- & -- \\
\hline & Totra & 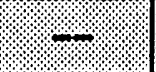 & 2. & 2 & ?.r. & -2 & ; \\
\hline \multirow{2}{*}{$\begin{array}{l}\text { Stone \& Webster } \\
\text { Engineering } \\
\text { Corporation }\end{array}$} & bargai & 12 & 10 & 10 & 10 & 10 & 10 \\
\hline & $10827 \%$ & 12 & 18 & 10 & 10 & 10 & 109. \\
\hline \multirow{2}{*}{$\begin{array}{l}\text { Westinghouse } \\
\text { Hanford Company }\end{array}$} & & $\begin{array}{c}1,882 \\
726\end{array}$ & 1,980 & $\begin{array}{c}2,155 \\
745\end{array}$ & $\begin{array}{l}2,270 \\
820\end{array}$ & $\begin{array}{c}2,350 \\
830\end{array}$ & $\begin{array}{c}2,375 \\
840\end{array}$ \\
\hline & Torar? & 2.608 & 2.720 & 2,900 & 8.690 & 3.180 & 3.245 \\
\hline \multirow{2}{*}{$\begin{array}{l}\text { U.S. Department } \\
\text { of Energy, } \\
\text { Richland Field } \\
\text { Office }\end{array}$} & $\begin{array}{l}\text { Office } \\
\text { bargail }\end{array}$ & 13 & $\begin{array}{l}75 \\
--\end{array}$ & $\begin{array}{l}75 \\
--\end{array}$ & $\begin{array}{l}75 \\
--\end{array}$ & $\begin{array}{l}80 \\
--\end{array}$ & $\begin{array}{l}80 \\
--\end{array}$ \\
\hline & 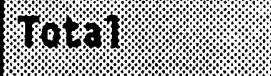 & 13 & 78 & 19 & 85 & 80 & 80 \\
\hline \multirow{2}{*}{$\begin{array}{l}\text { Total of } \\
\text { DOE and Site } \\
\text { Contractors }\end{array}$} & $\begin{array}{l}\text { Office/lab } \\
\text { bargaining }\end{array}$ & $\begin{array}{c}2,076 \\
869\end{array}$ & $\begin{array}{c}2,272 \\
870\end{array}$ & $\begin{array}{c}2,463 \\
875\end{array}$ & $\begin{array}{c}2,594 \\
950\end{array}$ & $\begin{array}{c}2,689 \\
960\end{array}$ & $\begin{array}{r}2,729 \\
970\end{array}$ \\
\hline & 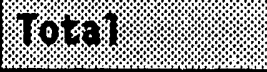 & 2,975 & $3.14 \%$ & 8,8389 & $3.54 \%$ & 3.649 & 3.699 \\
\hline $\begin{array}{c}\text { Construction } \\
\text { Workers }\end{array}$ & Toton? & 100 & 300 & 475 & 750 & 1.075 & 875 \\
\hline TOTAL & otrat? & 3.045 & $3,442 \%$ & 3.813: & 1.294 & 4.724 & 4.574 \\
\hline
\end{tabular}


Table B-2. 200 Area Corridor Projected Population (as of September 1992).

\begin{tabular}{|c|c|c|c|c|c|c|c|}
\hline \multirow{3}{*}{ Organization } & \multirow{3}{*}{$\begin{array}{l}\text { Type of } \\
\text { personnel }\end{array}$} & \multicolumn{6}{|c|}{ Fiscal year } \\
\hline & & \multirow{2}{*}{$\frac{\text { Actual }}{1992}$} & \multicolumn{5}{|c|}{ Projected } \\
\hline & & & 1993 & 1994 & 1995 & 1996 & 1997 \\
\hline \multirow{2}{*}{$\begin{array}{c}\text { Hanford } \\
\text { Environmental } \\
\text { Health } \\
\text { Foundation }\end{array}$} & $\begin{array}{l}\text { Office/lab } \\
\text { bargaining }\end{array}$ & -- & -- & -- & -- & -- & $\begin{array}{l}-- \\
--\end{array}$ \\
\hline & 10169 & ?.: & ?. & ?. & (2.: & ?+. & ?:-: \\
\hline \multirow{2}{*}{$\begin{array}{c}\text { Kaiser Engineers } \\
\text { Hanford }\end{array}$} & $\begin{array}{l}\text { Office/lab } \\
\text { bargaining }\end{array}$ & $\begin{array}{c}1 \\
15\end{array}$ & $\begin{array}{c}1 \\
20\end{array}$ & $\begin{array}{c}1 \\
20\end{array}$ & $\begin{array}{c}1 \\
25\end{array}$ & $\begin{array}{c}1 \\
25\end{array}$ & $\begin{array}{c}1 \\
30\end{array}$ \\
\hline & rotral & 16. & 14. & 21. & 26. & 26. & 31. \\
\hline \multirow{2}{*}{$\begin{array}{l}\text { Pacific } \\
\text { Northwest } \\
\text { Laboratory }\end{array}$} & $\begin{array}{l}\text { Office/lab } \\
\text { bargaining }\end{array}$ & $\begin{array}{c}8 \\
--\end{array}$ & $\begin{array}{c}8 \\
--\end{array}$ & $\begin{array}{c}8 \\
--\end{array}$ & $\begin{array}{c}8 \\
--\end{array}$ & $\begin{array}{c}8 \\
--\end{array}$ & $\begin{array}{c}8 \\
--\end{array}$ \\
\hline & 10180. & 8. & 8. & 8. & 8. & 8. & 8. \\
\hline \multirow{2}{*}{$\begin{array}{c}\text { Stone \& Webster } \\
\text { Engineering } \\
\text { Corporation }\end{array}$} & $\begin{array}{l}\text { Office/lab } \\
\text { bargaining }\end{array}$ & $\begin{array}{l}-- \\
--\end{array}$ & -- & $\begin{array}{l}-- \\
--\end{array}$ & - & -- & -- \\
\hline & 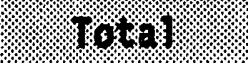 & ?:. & ?:. & ২.: & : & ?:. & ?:. \\
\hline \multirow{2}{*}{$\begin{array}{l}\text { West inghouse } \\
\text { Hanford Company }\end{array}$} & $\begin{array}{l}\text { Office/1ab } \\
\text { bargaining }\end{array}$ & $\begin{array}{l}75 \\
60\end{array}$ & $\begin{array}{l}120 \\
80\end{array}$ & $\begin{array}{l}120 \\
90\end{array}$ & $\begin{array}{l}120 \\
100\end{array}$ & $\begin{array}{l}120 \\
110\end{array}$ & $\begin{array}{l}120 \\
120\end{array}$ \\
\hline & $108 \%$ & 185 & $208 \%$ & $18 \%$ & 120 & 280 & 240 \\
\hline \multirow{2}{*}{$\begin{array}{c}\text { U.S. Department } \\
\text { of Energy, } \\
\text { Richland Field } \\
\text { Office }\end{array}$} & $\begin{array}{l}\text { Office/lab } \\
\text { bargaining }\end{array}$ & -- & - & - & -- & -- & -- \\
\hline & Trotar) & ?.:. & ?:. & ?.:- & ?.:. & ?.: & ?.:. \\
\hline \multirow[t]{2}{*}{ Total } & $\begin{array}{l}\text { Office/lab } \\
\text { bargaining }\end{array}$ & $\begin{array}{l}84 \\
75\end{array}$ & $\begin{array}{l}129 \\
100\end{array}$ & $\begin{array}{l}129 \\
110\end{array}$ & $\begin{array}{l}129 \\
125\end{array}$ & $\begin{array}{l}129 \\
135\end{array}$ & $\begin{array}{l}129 \\
150\end{array}$ \\
\hline & roros. & 159 & 229 & 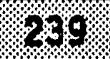 & 258 & 26. & $279:$ \\
\hline $\begin{array}{c}\text { Construction } \\
\text { Workers }\end{array}$ & rotal. & 20. & 58 & \%o & 1000 & 1008 & 4000 \\
\hline TOTAL & $10 \%$ & 179 & 279 & $389 \%$ & 858 & 964 & $1 / 279$ \\
\hline
\end{tabular}


Table B-3. 200 West Area Projected Population (as of September 1992).

\begin{tabular}{|c|c|c|c|c|c|c|c|}
\hline \multirow{3}{*}{ Organization } & \multirow{3}{*}{$\begin{array}{l}\text { Type of } \\
\text { personnel }\end{array}$} & \multicolumn{6}{|c|}{ Fiscal year } \\
\hline & & \multirow{2}{*}{$\frac{\text { Actual }}{1992}$} & \multicolumn{5}{|c|}{ Projected } \\
\hline & & & 1993 & 1994 & 1995 & 1996 & 1997 \\
\hline \multirow{2}{*}{$\begin{array}{c}\text { Hanford } \\
\text { Environmental } \\
\text { Health } \\
\text { Foundation }\end{array}$} & $\begin{array}{l}\text { Office/lab } \\
\text { bargaining }\end{array}$ & $\begin{array}{c}2 \\
-- \\
\end{array}$ & $\begin{array}{c}2 \\
-- \\
\end{array}$ & $\begin{array}{c}2 \\
-- \\
\end{array}$ & $\begin{array}{c}2 \\
-- \\
-\end{array}$ & $\begin{array}{c}2 \\
-- \\
\end{array}$ & $\begin{array}{c}2 \\
-- \\
\end{array}$ \\
\hline & 10196 & 2. & 2. & 2. & 2. & 2. & 2. \\
\hline \multirow{2}{*}{$\begin{array}{c}\text { Kaiser Engineers } \\
\text { Hanford }\end{array}$} & $\begin{array}{l}\text { Office/lab } \\
\text { bargaining }\end{array}$ & $\begin{array}{l}14 \\
86\end{array}$ & $\begin{array}{l}10 \\
70\end{array}$ & $\begin{array}{l}15 \\
75\end{array}$ & $\begin{array}{l}15 \\
75\end{array}$ & $\begin{array}{l}15 \\
80\end{array}$ & $\begin{array}{l}20 \\
80\end{array}$ \\
\hline & rotrit. & 100. & 80. & 90. & $90 \%$ & 96. & 100 \\
\hline \multirow{2}{*}{$\begin{array}{l}\text { Pacific } \\
\text { Northwest } \\
\text { Laboratory }\end{array}$} & $\begin{array}{l}\text { Office/lab } \\
\text { bargaining }\end{array}$ & -- & -- & -- & $\begin{array}{l}-- \\
--\end{array}$ & -- & $\begin{array}{l}-- \\
--\end{array}$ \\
\hline & Totra? & ?:?: & ?:? & ?:. & ?:.:. & ?:. & ?.:. \\
\hline \multirow{2}{*}{$\begin{array}{l}\text { Stone \& Webster } \\
\text { Engineering } \\
\text { Corporation }\end{array}$} & $\begin{array}{l}\text { Office/lab } \\
\text { bargaining }\end{array}$ & - & -- & -- & -- & $\overline{--}$ & -- \\
\hline & 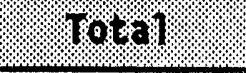 & ?.:. & ?.:. & ?.: & ?.:. & 12. & ?.: \\
\hline \multirow{2}{*}{$\begin{array}{l}\text { West inghouse } \\
\text { Hanford Company }\end{array}$} & $\begin{array}{l}\text { Office/lab } \\
\text { bargaining }\end{array}$ & $\begin{array}{l}867 \\
944 \\
\end{array}$ & $\begin{array}{l}950 \\
945\end{array}$ & $\begin{array}{l}985 \\
955\end{array}$ & $\begin{array}{c}1,025 \\
970\end{array}$ & $\begin{array}{c}1,050 \\
980 \\
\end{array}$ & $\begin{array}{c}1,070 \\
990\end{array}$ \\
\hline & 18018 & $1,81 \%$ & 1.896 & 1. 940 & $1 / 995$ & 2,030 & 2,060 \\
\hline \multirow{2}{*}{$\begin{array}{l}\text { U.S. Department } \\
\text { of Energy, } \\
\text { Richland Field } \\
\text { Office }\end{array}$} & $\begin{array}{l}\text { Office/lab } \\
\text { bargaining }\end{array}$ & $\begin{array}{c}2 \\
--\end{array}$ & $\begin{array}{l}10 \\
--\end{array}$ & 10 & $\begin{array}{l}10 \\
--\end{array}$ & $\begin{array}{l}10 \\
-- \\
\end{array}$ & $\begin{array}{l}10 \\
-- \\
\end{array}$ \\
\hline & 10\% & 2. & 10. & 10. & 10. & 10 & 10 . \\
\hline \multirow[t]{2}{*}{ Total } & $\begin{array}{l}\text { Office/lab } \\
\text { bargaining }\end{array}$ & $\begin{array}{c}885 \\
1,030 \\
\end{array}$ & $\begin{array}{c}972 \\
1,015 \\
\end{array}$ & $\begin{array}{l}1,012 \\
1,030\end{array}$ & $\begin{array}{l}1,052 \\
1,045\end{array}$ & $\begin{array}{l}1,077 \\
1,060\end{array}$ & $\begin{array}{l}1,102 \\
1,070\end{array}$ \\
\hline & Totral & 1.915 & 18987 & 2,042 & 2097 & $2.8 \%$ & 12.172 \\
\hline $\begin{array}{c}\text { Construction } \\
\text { Workers }\end{array}$ & rotrol. & 25 & $79 \%$ & 150 & 350. & 500 & $600 \%$ \\
\hline TOTAL & Total? & 1,940 & 2,062 & 2.192 & 2,447 & 2,639 & 2.772 \\
\hline
\end{tabular}




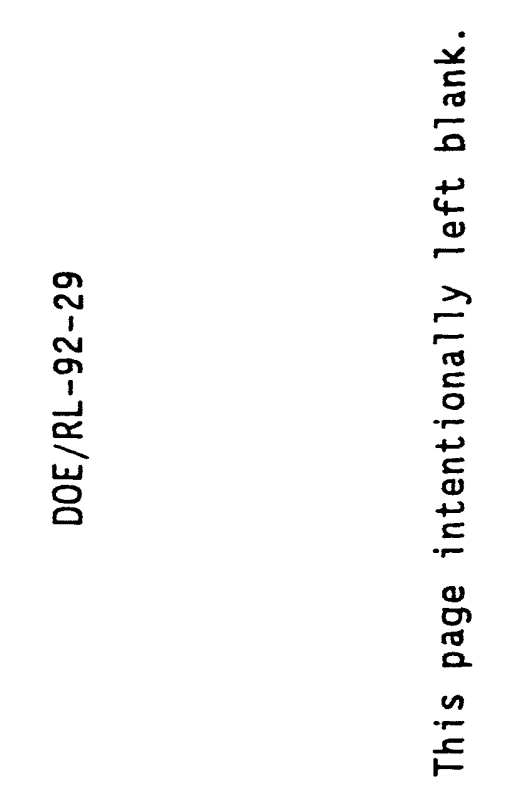


DOE/RL-92-29

APPENDIX C

SITE INFORMATION

$$
\text { C-1 }
$$




\section{DOE/RL-92-29}

This page intentionally left blank.

\section{C-2}


DOE/RL-92-29

APPENDIX C

SITE INFORMATION

CONTENTS

C.1 HISTORY . . . . . . . . . . . . . . . C C-5

C.2 LAWS AND REgULATIONS ................. . . . . . .

C.3 PHYSICAL CHARACTERISTICS OF THE 200 AREAS . . . . . . . C-6

C.3.1 Geology ................. C-6

C.3.2 Wetlands . . . . . . . . . . . . . C-7

C.3.3 Hydrology ................... C-7

C.3.4 Vegetation ................ C-7

C.3.5 Ecological Areas ............... . C-7

C.3.6 Threatened and Endangered Species . . . . . . . . C-8

C.3.7 Historical, Archaeological, and Cultural Resources . . C-8

C.3.8 Meteorology . . . . . . . . . . . . . . C-8

C.4 REFERENCES ...................... C-9 
DOE/RL-92-29

This page intentionally left blank. 


\section{APPENDIX C \\ STTE INFORMATION}

This appendix briefly highlights the major historical trends, the laws and regulations affecting current and future use, and the general physical characteristics of the 200 Areas.

\section{C.1 HISTORY}

In January 1943, the U.S. Army Corps of Engineers, Manhattan District, chose the Hanford Site for the Hanford Engineering Works, where facilities would be built to produce plutonium for the world's first nuclear weapons. During this same timeframe, the 200 East and 200 West Areas were dedicated for the construction of facilities to process spent fuel from production reactors at the Hanford Site. The 200 Area Corridor (between the 200 East and 200 West Areas) remained largely, undeveloped throughout the early years of the Hanford Site. In the late $1980^{\prime} \mathrm{s}$, the 200 Areas primary mission shifted from defense production to environmental restoration with some subsequent diversification into research and development.

\section{C.2 LANS AND REGULATIONS}

All 200 Areas' activities must comply with all applicable Federal, State, and local laws and regulations, and applicable U.S. Department of Energy (DOE) orders. The Hanford Site Development Plan (DOE-RL 1990) lists and discusses some of the most significant laws, regulations, and DOE orders that impact current and future use of the Hanford site. The majority of these legislative actions will influence existing and future operations in the 200 Areas. Because of the comprehensive discussion in the Hanford Site Development Plan (DOE-RL 1990), only a listing of some of the most important laws and regulations affecting the 200 Areas will be provided.

\section{Federal Government}

- Comprehensive Environmental Response, Compensation, and Liability Act of 1980, 42 USC 9601 et seq., as amended by the Superfund Amendments and Reauthorization Act of 1986

- National Environmental Policy Act of 1969, 42 USC 4321, et seq.

- Resource Conservation and Recovery Act of 1976, as amended, 42 USC 6901 , et seq.

State of Washington [Revised Code of Washington (RCW)]

- Washington State Hazardous Waste Management Act, RCW 70.105

- Onsite Disposal of Solid and Liquid Wastes Act, RCW 43.20.050 
- Washington (State) Administrative Code (WAC):

- "State Waste Discharge Program, " WAC 173-216

- "Dangerous Waste Regulations," WAC 173-303

- "Onsite Sewage Disposal," WAC 248-96

- Washington Clean Air Act of 1976, RCW 70.94.

Regulatory Documentation

- Hanford Federal Facility Agreement and Consent Order.

\section{C.3 PHYSICAL CHARACTERISTICS OF THE 200 AREAS}

This section briefly describes the natural factors and associated constraints of the 200 Areas. The referenced material at the end of each section provides a complete discussion of that topic. The following topics are covered: geology; hydrology; vegetation; ecological areas; threatened and endangered species; historical, archaeological, and cultural resources; and meteorology.

\section{C.3.1 Geology}

The elevation in the 200 Areas varies from 190 to $245 \mathrm{~m}(623$ to $804 \mathrm{ft}$ ) above mean sea level. The major geologic units beneath the 200 Areas are, in ascending order, basement rocks of undetermined origin, the Columbia River Basalt Group, the Ringold Formation, the Plio-Pleistocent unit, and the Hanford formation. The surface of the 200 Areas is hidden with loess and sand dunes of varying thickness.

The Columbia River Basalt Group is a thick sequence of tholeiftic basalts, which form the bedrock beneath the Hanford Site. In the 200 Areas, this layered sequence is subdivided into five formations and is at least $1,460-\mathrm{m}(4,818-\mathrm{ft})$ thick and may be as much as $4,267-\mathrm{m}(14,081-\mathrm{ft})$ thick.

The Ringold Formation overlies the basalts. In the 200 Areas, this formation consists of a series of sandy silt and clay layers. The Ringold Formation averages about $120-\mathrm{m}(396-\mathrm{ft})$ thick beneath the 200 West Area and about 60-m (198-ft) thick beneath the 200 East Area.

Overlying the Ringold Formation is the Plio-Pleistocene unit. In the 200 Areas, the sediments of this unit are typically fine grained, consisting predominantly of very fine sand and silt. The Plio-Pleistocene unit about 6-m $(20-\mathrm{ft})$ thick on average.

Overlying the Plio-Pleistocene unit is the Hanford formation. In the 200 Areas, this formation consists of unconsolidated gravels and sands with some boulders and cobbles. The Hanford formation averages about $45-\mathrm{m}(149-\mathrm{ft})$ thick beneath the 200 West Area and about $60-\mathrm{m}$ (198-ft) thick beneath the 200 East Area (Cushing 1991). 


\section{C.3.2 Wetlands}

Aquatic habitats on the Hanford Site include the ponds and ditches in or near the 200 Areas, the Columbia River, and several very small streams. The wastewater disposal sites have similar water-quality characteristics and support similar kinds of algae, rooted plants, and invertebrates.

The ponds and ditches are the only sources of water in the 200 Areas and, therefore, provide habitat for many birds and mammals. The ditches are generally less productive than the ponds in terms of avallable biomass. Streams formed by surrounding springs are quite productive and are in remote locations from the waste sites (DOE-RL 1990).

\section{C.3.3 Hydrology}

Both unconfined and confined aquifers are present beneath the 200 Areas. The uppermost aquifer is unconfined; underlying aquifers are contained in the basalts and are generally confined. The unconfined aquifer is affected by disposal of wastewater to surface and subsurface disposal sites. The depth to groundwater in the 200 West Area is about 50 to $60 \mathrm{~m}$ (165 to $198 \mathrm{ft}$ ) and about $75 \mathrm{~m}(248 \mathrm{ft})$ in the 200 East Area.

The unconfined aquifer beneath the 200 Areas receives artificial recharge from liquid disposal sites. Many of these liquid disposal sites have been reduced, with an accompanying decline in water table elevations. The sources of natural recharge to the unconfined aquifer are from rainfall and two intermittent streams. From the areas of recharge, the groundwater flows downgradient to discharge areas, primarily along the Columbia River. This west-to-east flow pattern is interrupted by groundwater mounds, created by artificial recharge, in the 200 Areas. From the 200 Areas, groundwater also flows to the north, between Gable Mountain and Gable Butte (Cushing 1991).

\section{C.3.4 Vegetation}

Vegetation in the 200 Areas is typical of semiarid regions. The dominant plants in the 200 Areas are big sagebrush, rabbitbrush, cheatgrass, and Sandberg's bluegrass, with cheatgrass providing half of the total plant cover. The sagebrush and cheatgrass or Sandberg's bluegrass is perhaps the most common in the 200 Areas. Cottonwood, willows, cattails, and bulrushes grow along ponds and ditches (Cushing 1991).

\section{C.3.5 Ecological Areas}

The ponds and ditches near the 200 Areas and the cribs near the 200 Areas are primary ecological study areas. The ponds and ditches near the 200 Areas focus on lake and pond radioecology by performing studies of phyto- and zooplankton, algae, fish, waterfowl, and mammals. The cribs near the 200 Areas focus on terrestrial ecology of waste disposal practices, revegetation of disturbed soll, dispersal of radionuclides via food habits of insects and jackrabbits, small mammals, root distribution of native plants, soil-plant uptake studies, and foodchain dynamics (DOE-RL 1990). 


\section{C.3.6 Threatened and Endangered Species}

Threatened and endangered plants and animals on the Hanford Site, as listed by the federal government (50 CFR 17) and Washington State (Washington National Heritage Program 1990), are shown in Table C-1. No plants or mammals on the federal list of Endangered and Threatened Wildlife Plants (DOI 1986; 50 CFR 17.11, 17.12) are known to occur on the Hanford Site. There are, however, several species of both plants and animals that are under consideration for formal listing by the federal government and Washington State (Cushing 1991).

Table C-1. Threatened and Endangered Species.

\begin{tabular}{|l|l|c|c|}
\hline \multicolumn{1}{|c|}{ Common name } & \multicolumn{1}{|c|}{ Scientific name } & Federal & State \\
\hline Plants & & T \\
\hline Columbia milk-vetch & Astragalus columbianus & & E \\
\hline Yellowcress & Rorippa columbiae & & T \\
\hline Hoover's desert parsley & Lomatium tuberosum & E & E \\
\hline Birds & \multicolumn{3}{|l|}{} \\
\hline Aleutian Canada goose & Branta canadensis leucopariea & E & E \\
\hline Pererine falcon & Falco perregrinus & T & T \\
\hline Bald eagle & Haliaeetus leucocephalus & & E \\
\hline White pelican & Pelecanus erythorhychos & & E \\
\hline Sandhill crane & Grus canadensis & & T \\
\hline Gerruginous hawk & Buteo regalis & \\
\hline
\end{tabular}

$E=$ Endangered

T = Threatened.

\section{C.3.7 Historical, Archaeological, and Cultural Resources}

An archaeological survey has been completed for all undeveloped 1 and in the 200 East Area, and a 50 percent random sample has been completed for undeveloped land in the 200 West Area. No archaeological sites or areas of Native American interest were identified in the 200 East Area and 200 West Area, and none are known to exist within $2 \mathrm{~km}(1.3 \mathrm{mi})$ of their boundaries. The only historic site is the old White Bluffs freight road that crosses diagonally through the 200 West Area. This road is considered to be eligible for the National Register of Historical Places. A $100 \mathrm{~m}$ easement has been created to protect the road from uncontrolled disturbances (Cushing 1991). 


\section{C.3.8 Meteorology}

The prevalling wind directions in the 200 Areas are from the northwest in all months of the year. During the winter and summer, winds from the northwest occur more frequently. During the spring and fall, winds from the southwest increase and winds from the northwest decrease. Monthly average wind speeds are lowest during the winter months, averaging 10 to $11 \mathrm{~km} / \mathrm{h}$ $(6.8 \mathrm{mi} / \mathrm{h})$, and highest during the summer, averaging 14 to $16 \mathrm{~km} / \mathrm{h}(9.9 \mathrm{mi} / \mathrm{h})$. The highest wind speeds are usually associated with winds from the southwest.

The average monthly temperatures at the Hanford Meteorology Station (located in the 200 Area Corridor) for the perlod of 1912 through 1980 range from a low of $-1.5^{\circ} \mathrm{C}\left(29^{\circ} \mathrm{F}\right)$ in January to a high of $24.7^{\circ} \mathrm{C}\left(76^{\circ} \mathrm{F}\right)$ in July. The lowest recorded monthly average winter temperature is $-5.9^{\circ} \mathrm{C}\left(21^{\circ} \mathrm{F}\right)$, and the highest recorded monthiy average winter temperature is $6.9^{\circ} \mathrm{C}\left(44{ }^{\circ} \mathrm{F}\right)$. The highest recorded monthly average summer temperature is $27.9^{\circ} \mathrm{C}\left(82{ }^{\circ} \mathrm{F}\right)$. The coolest summer month on record is June with an average of $17.2{ }^{\circ} \mathrm{C}\left(63^{\circ} \mathrm{F}\right)$.

The annual average relative humidity at the Hanford Meteorology Station is 54 percent. During the winter, humidity is higher than the annual average (averaging about 75 percent), and during the summer, lower than the annual average (averaging about 35 percent).

The average annual precipitation at the Hanford Meteorology Station is $16 \mathrm{~cm}(6.3 \mathrm{in.})$. The total annual precipitation ranges from 7.6 to $27.9 \mathrm{~cm}$ ( 3 to 11 in.). Most of the precipitation takes place during the winter (DOE-RL 1990; Cushing 1991).

\section{C.4 REFERENCES}

Comprehensive Environmental Response, Compensation, and Liability Act of 1980, as amended, 42 USC 7401.

Cushing, 1989, Hanford Site NEPA Characterization, PNL-6415, Rev. 2, Pacific Northwest Laboratory, Richland, Washington.

Cushing, 1991, Hanford Site NEPA Characterization, PNL-6415, Rev. 4, Pacific Northwest Laboratory, Richland, Washington.

DOE-RL, 1990, Hanford Site Development Plan, DOE/RL-89-15, U.S. Department of Energy-Richl and Operations Office, Richland, Washington.

Ecology, 1990a, "State Waste Discharge Program," WAC 173-216, Washington (State) Administrative Code, Washington State Department of Ecology, Olympia, Washington.

Ecology, 1990b, "Dangerous Waste Regulations," WAC 173-303, Washington (State) Administrative Code, Washington State Department of Ecology, Olympia, Washington.

Ecology, 1990c, "Onsite Sewage Disposal," WAC 248-96, Washington (State) Administrative Code, Washington State Department of Ecology, Olympia, Washington. 
Ecology, EPA, and DOE, 1990, Hanford Federal Facility Agreement and Consent Order, 2 vols., as amended, Washington State Department of Ecology, U.S. Environmental Protection Agency, and U.S. Department of Energy, Olympia, Washington.

National Environmental Policy Act of 1969, as amended, 42 USC 4321 et seq. Onsite Disposal of Solid and Liquid Wastes Act, RCW 43.20.050.

Resource Conservation and Recovery Act of 1976, as amended, 42 USC 6901 et seq.

Superfund Amendments and Reauthorization Act of 1986, 42 USC 11001 et seq. Washington Clean Air Act of 1976, RCW 70.94 .

Washington State Hazardous Waste Management Act, RCW 70.105. 


\section{DOE/RL-92-29}

\section{APPENDIX D}

\section{PACIFIC NORTHWEST LABORATORY PROPOSED CONSTRUCTION}

RESTRICTIONS IN CORRIDOR AREA 
DOE/RL-92-29

This page intentionally left blank. 
DOE /RL $-92-29$

March 6, 1991

Mr. Scott Seiler

Acting Manager

WHC Site Planning

Westinghouse Hanford Company

P.0. Box 1970

Richland, HA 99352

Dear Mr. Seiler:

Attached for your information is the proposed construction and land use

restrictions for the area near the Hanford Weather Station in the 600 Area.

This report is a more detalled revision of an earlfer report dated September 26, 1990.

PNL would like to see these restrictions included in future versions of the 200 Area LAPAs and, where appropriate, site evaluation reports.

If you have any questions, please contact Mr. Ed Yancey on 376-3960.

Very truly yours,

inculeleamis

MA Williams, Manager

Facilities Administration

CC: MJ Plahuta, DOE-RL

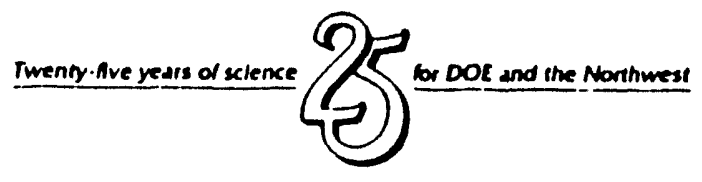


$\mathrm{DOE} / \mathrm{RL}-92-29$

Proposed Construction Restrictions for Area

East of the 622 Building Complex

Battelle Pacific Northwest Laboratory

February 26, 1991 


\section{APPENDIX D \\ PNL PROPOSED CONSTRUCTION RESTRICTIONS IN CORRIDOR AREA}

The PNL Atmospheric Sciences Department has a continuing interest in maintaining the area around the 622 building complex for use in future meteorological field measurement programs. In the past, the area to the east, northeast, and southeast of the $122-\mathrm{m}(400-\mathrm{ft})$ meteorological tower was used for a series of tracer measurements to characterize atmospheric diffusion, and for measurements of atmospheric turbulence, instrument testing, and dispersion model evaluation. Sampling arcs extending to $25 \mathrm{~km}$ (15 mi) were maintained, although the 200 East complex of buildings could be considered a major disruption to flow patterns over the region. In particular, the area out to the $3200 \mathrm{~m}$ ( $2 \mathrm{mi})$ sampling arc was almost completely undisturbed and it was possible to obtain high quality, representative meteorological measurements for stlidies in atmospheric turbulence and diffusion. These measurements have formed the basis for a wide range of theoretical and practical advances in atmospheric science, and the data have been employed by scientists throughout the world. Results obtained from studies in this area have been used by DOE, the U.S. Environmental Protection Agency, and the Nuclear Regulatory Commission for basic research and in the testing and evaluation of atmospheric dispersion models and regulatory codes.

The location of the supporting facilities at the 662 weather station, the availability of roads in the area, the relative uniformity of the terrain and surface cover, the largely unobstructed exposure in all directions, and the historical data base ( $>40$ years) collected in the region all make it essential that this area be preserved for future use. Although the particular studies carried out by atmospheric scientists change from year to year, the region is still the prime area on the Hanford Site for many meteorological measurements. For example, one of the major new initiatives begun by DOE involves a program of study in global climate change. The results of this study, which is expected to last 10 years or more, may have major impacts on future national energy policy, resource development, and economic policy. PNL has a lead role in this program, and part of its activities will involve the testing and evaluation of meteorological instruments. The area around the 622 complex will be used this spring for measurements of this kind, and similar activities are likely in the future. In recent years, hydrological programs have also been carried out near this area. These studies have helped to establish the behavior of soils in the uptake, evaporation, and flowthrough of water, an important issue in the assessment of environmental hazards from buried waste. Unfortunately, current and proposed construction in the area poses a serious threat to the continuation of such research and measurements. To ensure the continued availability of this region for studies such as these, we request that no further development be permitted in the proposed experimental areas.

The requested restriction on further development can be understood in terms of the conditions necessary to establish a representative "microclimate" in which measurements can be carried out. A rule of thumb for micrometeorological measurements is that for an accurate determination of ambient turbulent quantities, such as vertical fluxes of heat or water vapor, the uniform, undisturbed upwind fetch should be between 100 and 200 times the height at which measurements are taken. ("Fetch" refers to the terrain, 
surface type, distribution of heat sources, etc. that describe the local conditions.) It is these turbulent fluxes that play a major role in governing the dispersion of atmospheric pollutants, the evaporation of water from the ground (and, therefore, its migration into the soil), and the winds and temperatures in the 1 owest $1000 \mathrm{~m}$ of the atmosphere. Because of a combination of factors involving some theoretical considerations and the intrinsic characteristics of the instruments used to measure turbulent quantities, such turbulence measurements are typically taken at height of 5-10 m or more; this requires an undisturbed fetch of up to $2000 \mathrm{~m}$.

With existing structures already in place in the 622, $200 \mathrm{E}$ and $200 \mathrm{~W}$ areas, and with some upgrades to facilities inevitable, it is no longer possible to obtain an undisturbed fetch of this extent, except for some limited ranges of wind directions. To avoid further losses in the utility of the site, we propose that the following areas be protected from new construction:

1. A circular region surrounding the $122-\mathrm{m}(400 \mathrm{ft})$ meteorological tower, extending outward for at least 400 meters $(1300 \mathrm{ft})$ in all directions.

2. A circular region of at least $1200-\mathrm{m}$ (3900 ft) radius, centered on the middle $61-\mathrm{m}(200-\mathrm{ft})$ tower on the $1600-\mathrm{m}(5250-\mathrm{ft})$ arc, at an azimuth of approximately 114 degrees from the 122-m meteorological tower.

3. The region to the north and east of the 622 complex, in the area of the old runway.

The stippled areas in the map attached to this discussion shows the proposed exclusion areas. The winds in this region blow from the north northwest through south southwest about $65 \%$ of the time. However, other wind directions do occur and for this reason we have requested circular exclusion zones rather than some other shape. In the event of proposed modifications to existing facilities, we request that we be allowed to review the modifications on a case-by-case basis.

New facilities outside but close to the boundaries of these areas would be acceptable if they do not seriously affect wind flow, temperature, and humidity patterns in the area or provide major disruptions in the natural surface.

Buildings of several stories height or facilities that involve major earth moving activities will almost certainly pose a problem even if they are outside but near the critical areas. The recently approved site for the Waste Sampling and Characterization Facility is a good example. While it probably will have only a minor impact on measurements taken on the $1600 \mathrm{~m}$ sampling arc, it effectively eliminates the region around the $122 \mathrm{~m}$ tower as a useful release point for a variety of tracer measurements, such as those carried out in the past and used by DOE and the NRC.

Building construction projects are not the only possible problem. Any disturbance of the natural vegetation cover, such as that associated with road construction or test well drilling, will have detrimental effects for the reasons cited above. An example is the construction of extensive paved parking areas, which provide localized sources of heat that differ greatly from that arising from an equal area of the natural surface cover in the region. Once disturbed, the vegetation may be expensive and difficult to restore, and the process may take many years. In the event that nothing is done to repair damage to the area, its utility for micrometeorological measurements may be permanently lost. 
DOE/RL-92-29 
$D O E / R L-92-29$

This page intentionally left blank. 


\section{DISTRIBUTION}

Number of Copies

ONSITE

125

U.S. Department of Energy.

Bichland Operations effice

R. W. Small (30)

A7-27

Hanford Environmental Health Foundation

S. A. Thompson

B5-16

Kaiser Engineers Hanford

B. E. Hubbard (2) G7-01

Pacific Northwest Laboratory

M. A. Williams P7-60

Westinghouse Hanford Company

W. T. Alumkal

R2-52

A. D. Ballinger

H1-62

T. B. Bergman

B2-17

R. J. Bliss

B3-04

M. D. Brincat

(5)

R. A. Carlson

S1-06

D. B. Cartmell

K. S. Daly

J. L. Denning

A. Y. Dingle

J. L. Deichman

H6- 03

R3-56

B4-64

B4-40

B4-65

R. H. Engelman

B1-59

H6-26

D. R. Fox

A. D. Gadeken

H1-62

B4-52

R. J. Giroir

T4-05

D. E. Good

S3-97

A. Greenberg

S2-66

J. M. Hache

S2-12

W. H. Hamilton, Jr.

P. L. Hapke

H. D. Harmon

N3-10

T4-05

G. A. Harvey

R2-52

B4-52 


\section{DISTRIBUTION (continued)}

\section{Number of Copies}

ONSITE

\section{West inghouse Hanford Company (cont inued)}

B. A. Holmberg

G4-02

J. O. Honeyman

$B 2-30$

M. C. Hughes

R2-81

K. D. Johnson

H5 -33

J. R. Knight

B3-04

M. K. Korenko

$B 3-08$

K. M. Liikala

A2-24

M. M. McCarthy

N3-13

H. E. McGuire

B3-63

S. M. O'Toole

H5-38

A. L. Pajunen

R. W. Powell

W. A. Retterer

H5-49

C. A. Rinne

H4 -14

R. J. Roberts

S2-20

J. H. Roecker

B4-64

W. G. Ruff

N3-13

B1 -59

R. M. Schwenk

S. W. Seiler

R. A. Smith

R3-50

B5-30

R. D. Stephens

B4-64

T. C. Varljen

G6-02

C. W. Walton

$\mathrm{N} 1-29$

H5-27

G. L. Wiggins

เ6-1]

R. D. Wojtasek

G4-12

H6-27

H. H. Yoshikawa

B2-30

Information Release

Administration (3)

A3-36

Hanford Technical Library

P8-55

Central Files

L8-15

Public Reading Room

$\mathrm{H} 2-53$ 


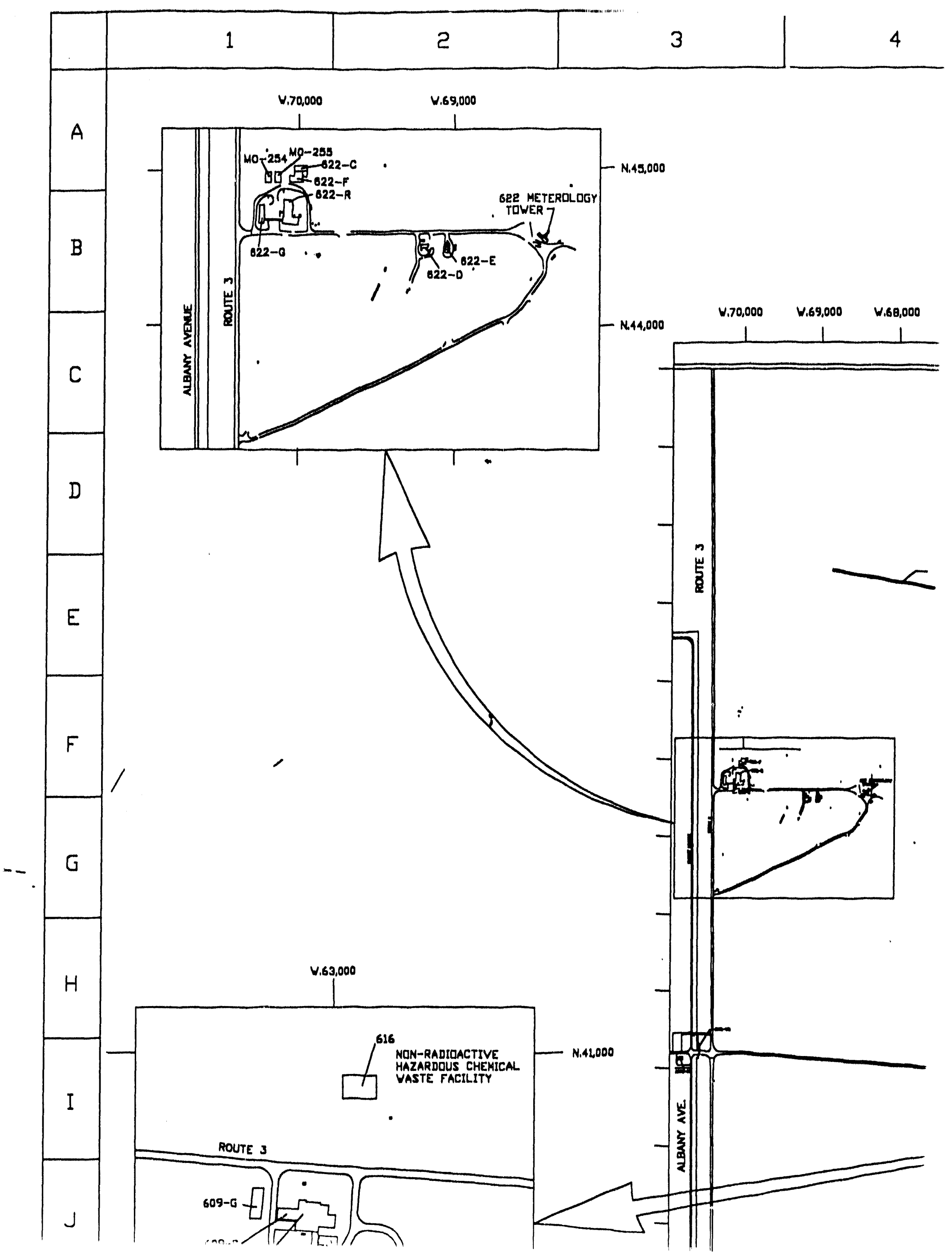




\begin{tabular}{|l|l|l|l|l}
5 & 6 & 1 & 0 \\
\hline
\end{tabular}

LANDING STRIP

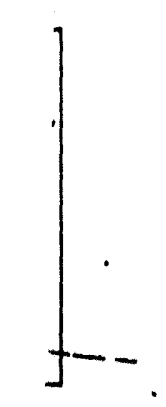

8 


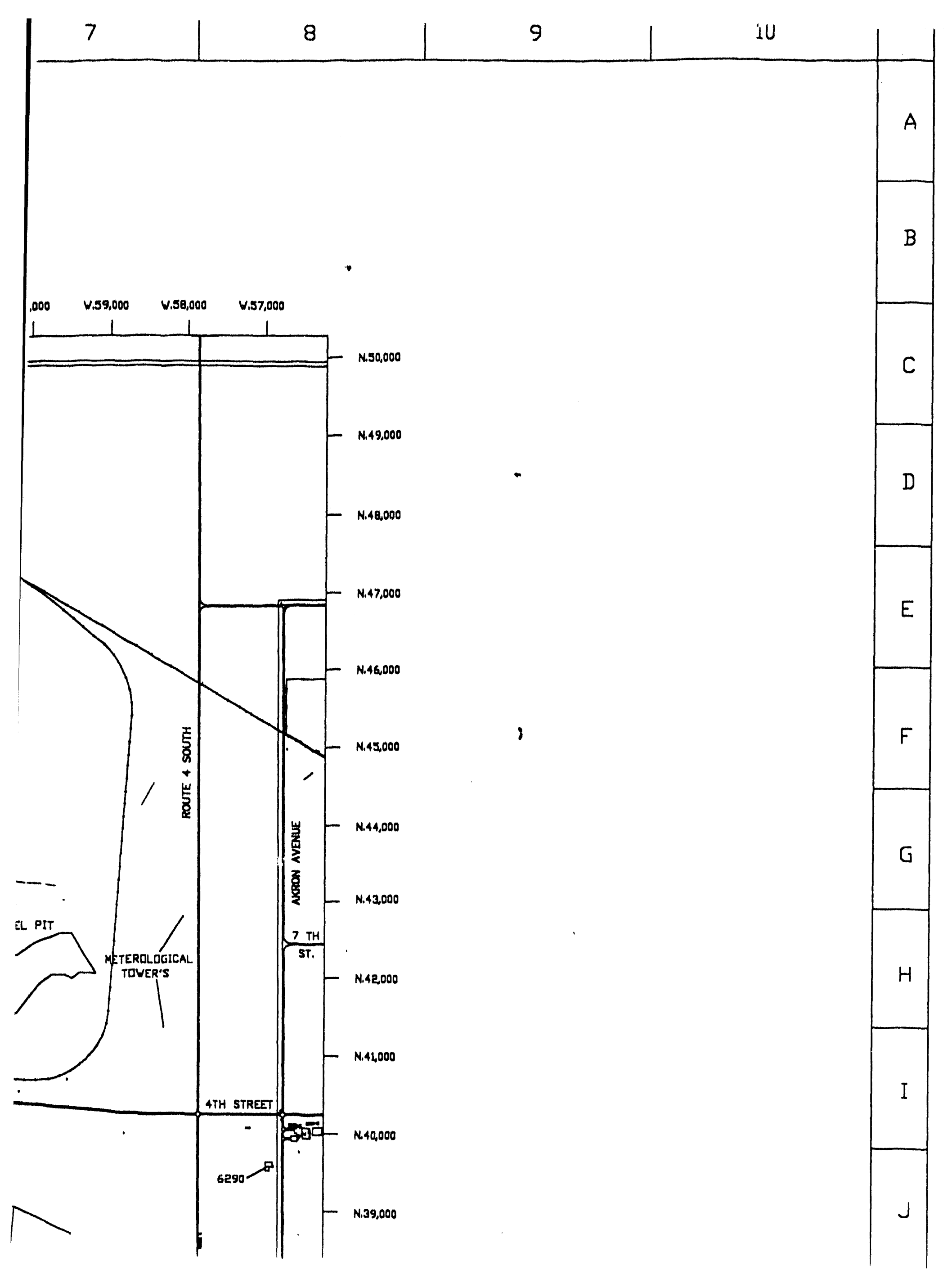




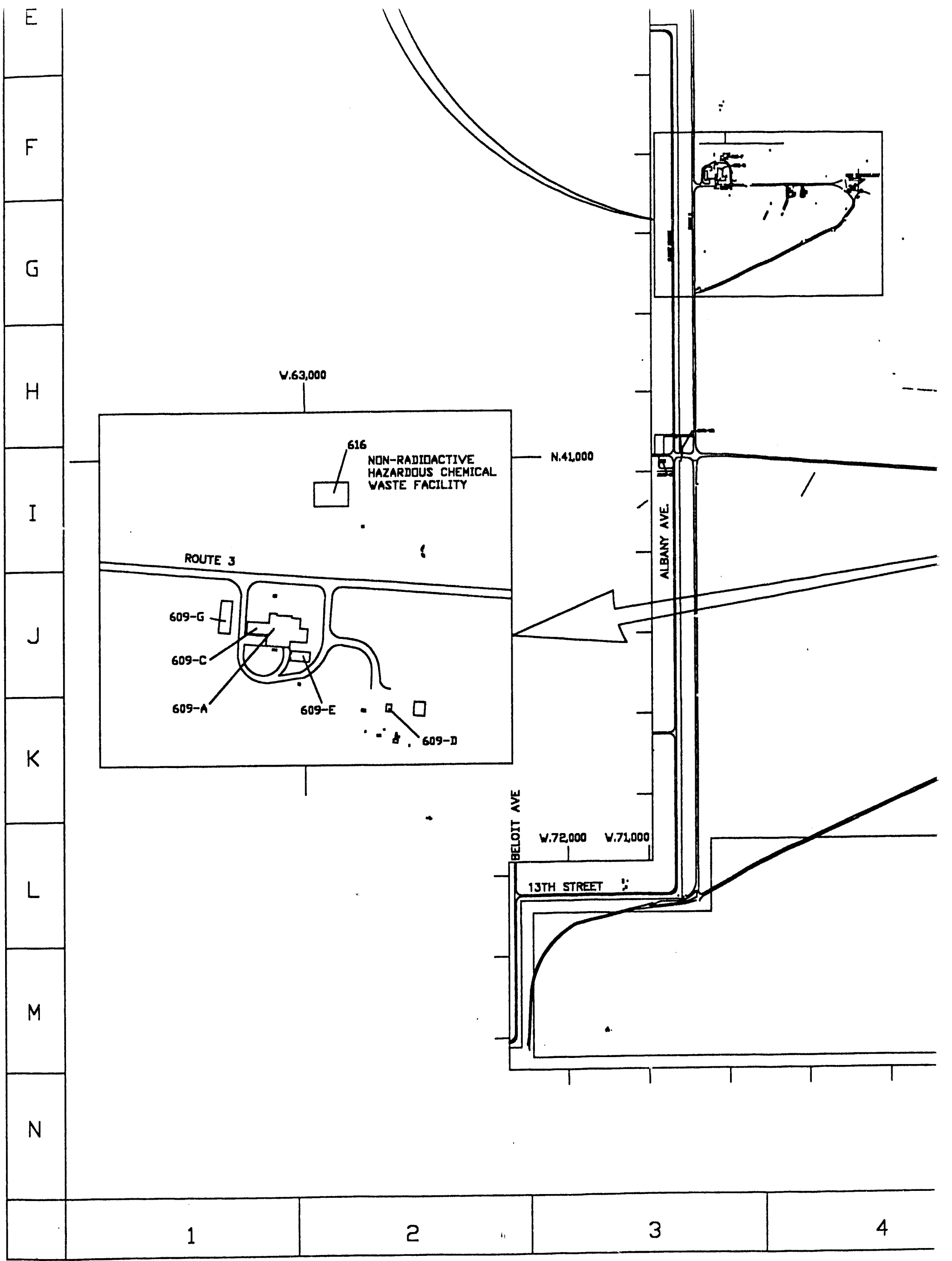




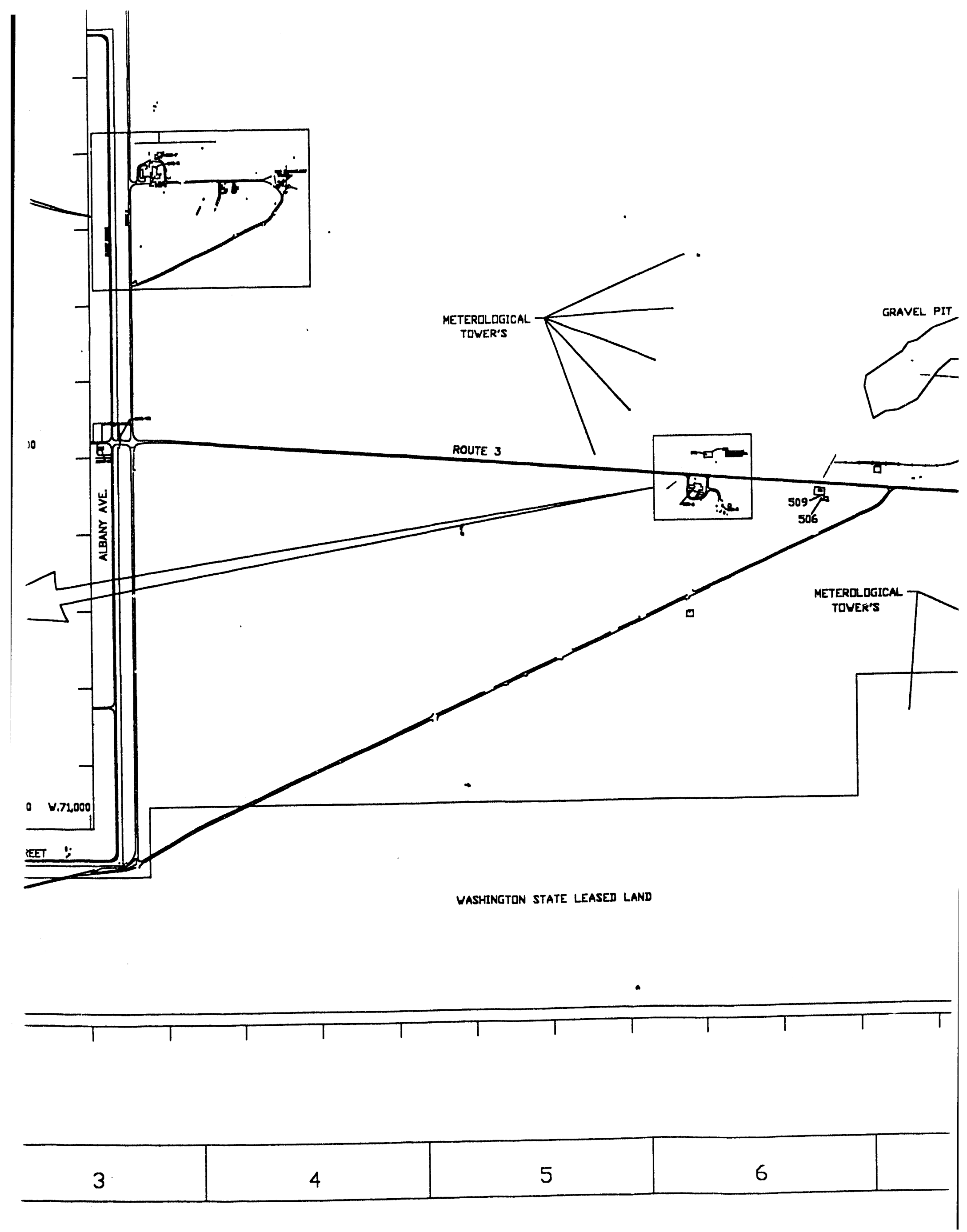




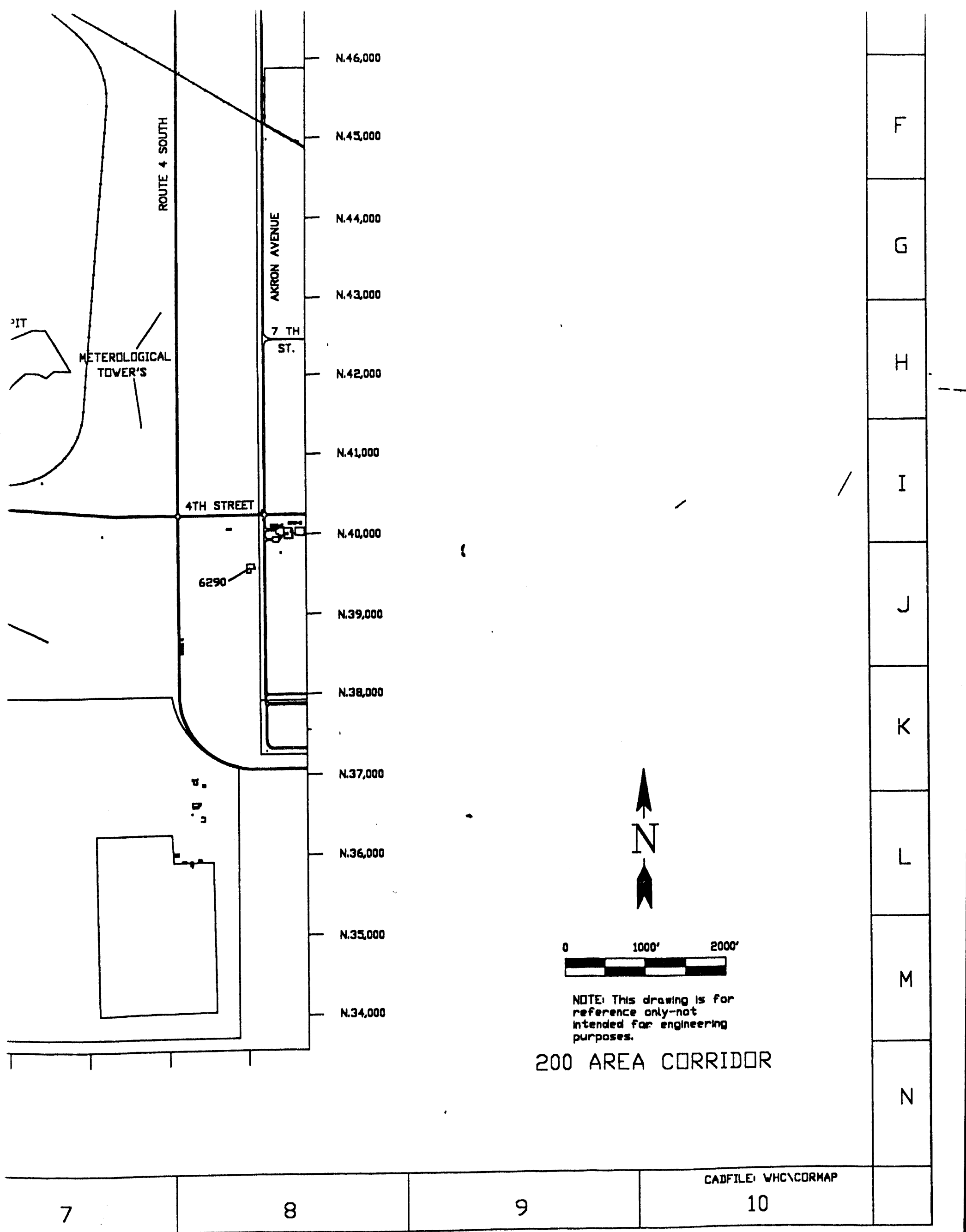




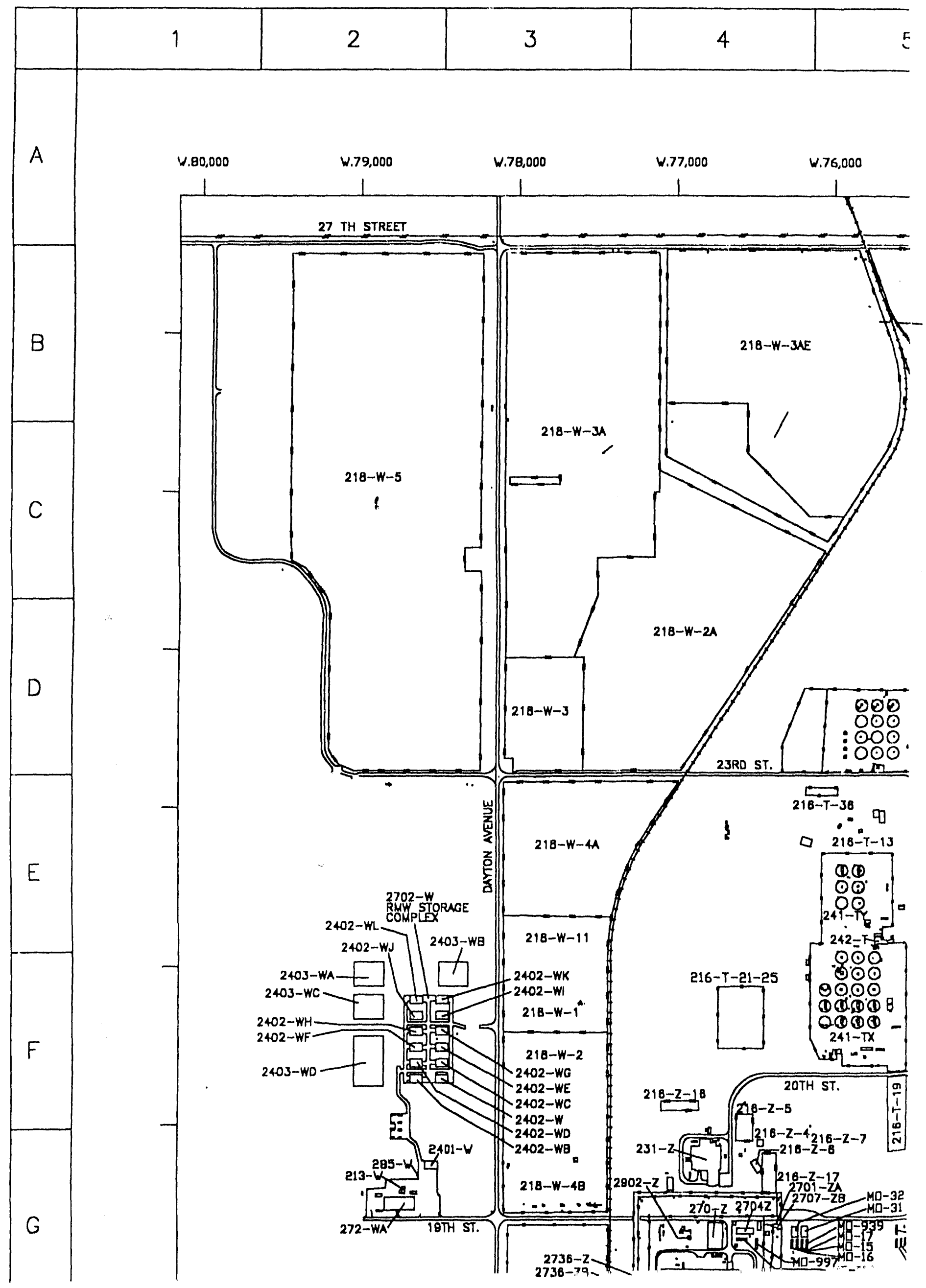




\begin{tabular}{l|l|l|l|l|l}
\hline 6 & 6 & 7 & 8 & 9 & 10 \\
\hline
\end{tabular}

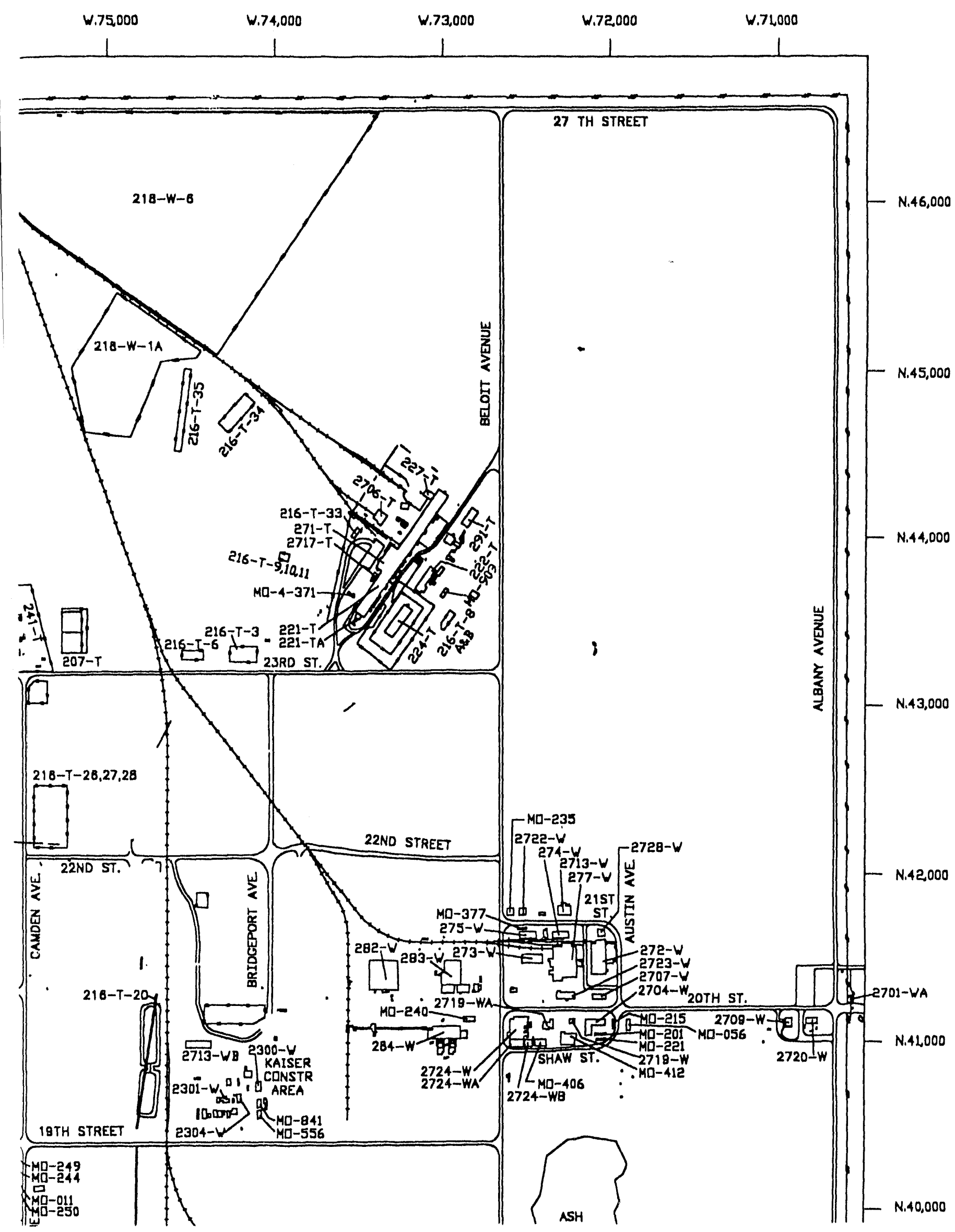




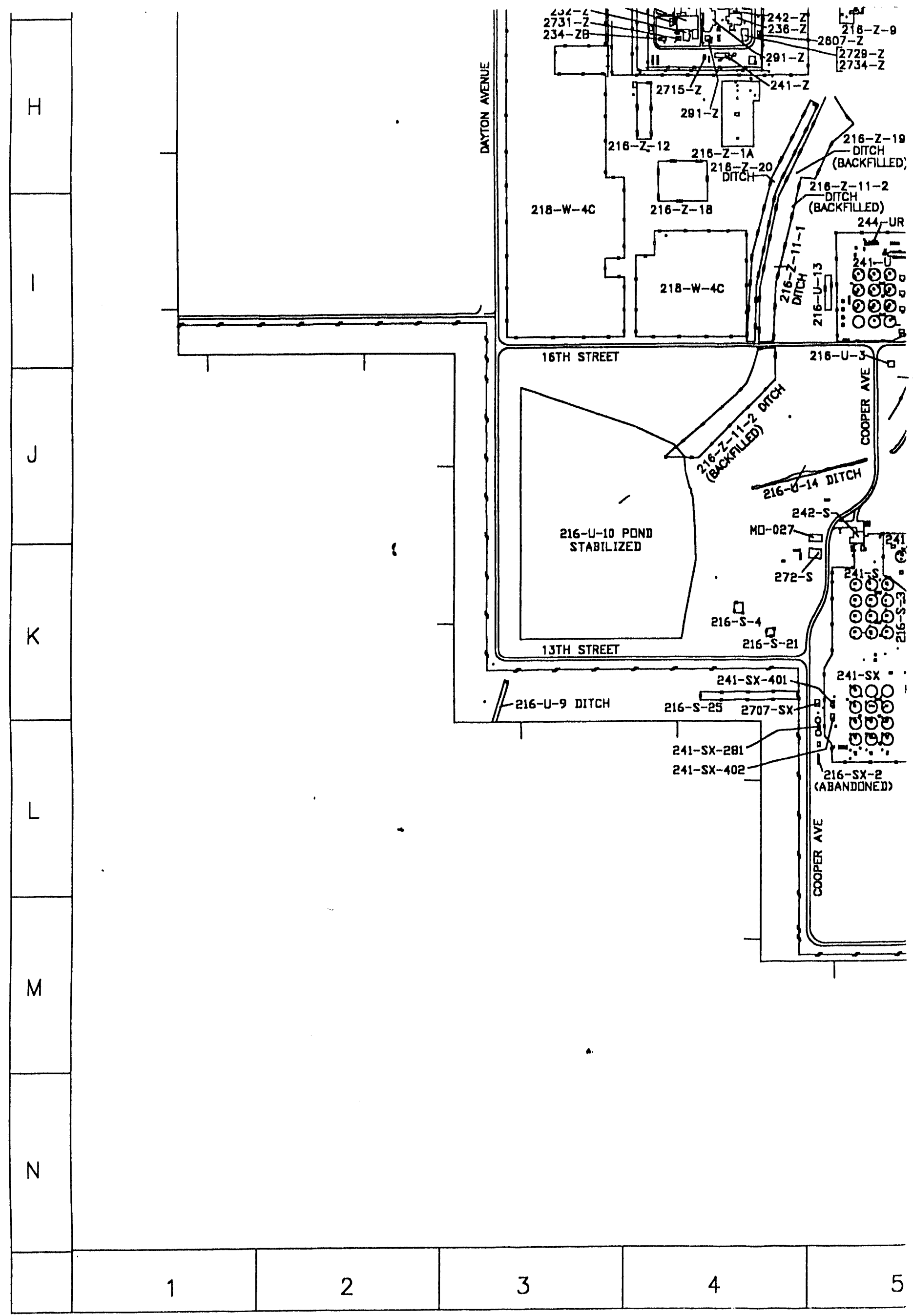




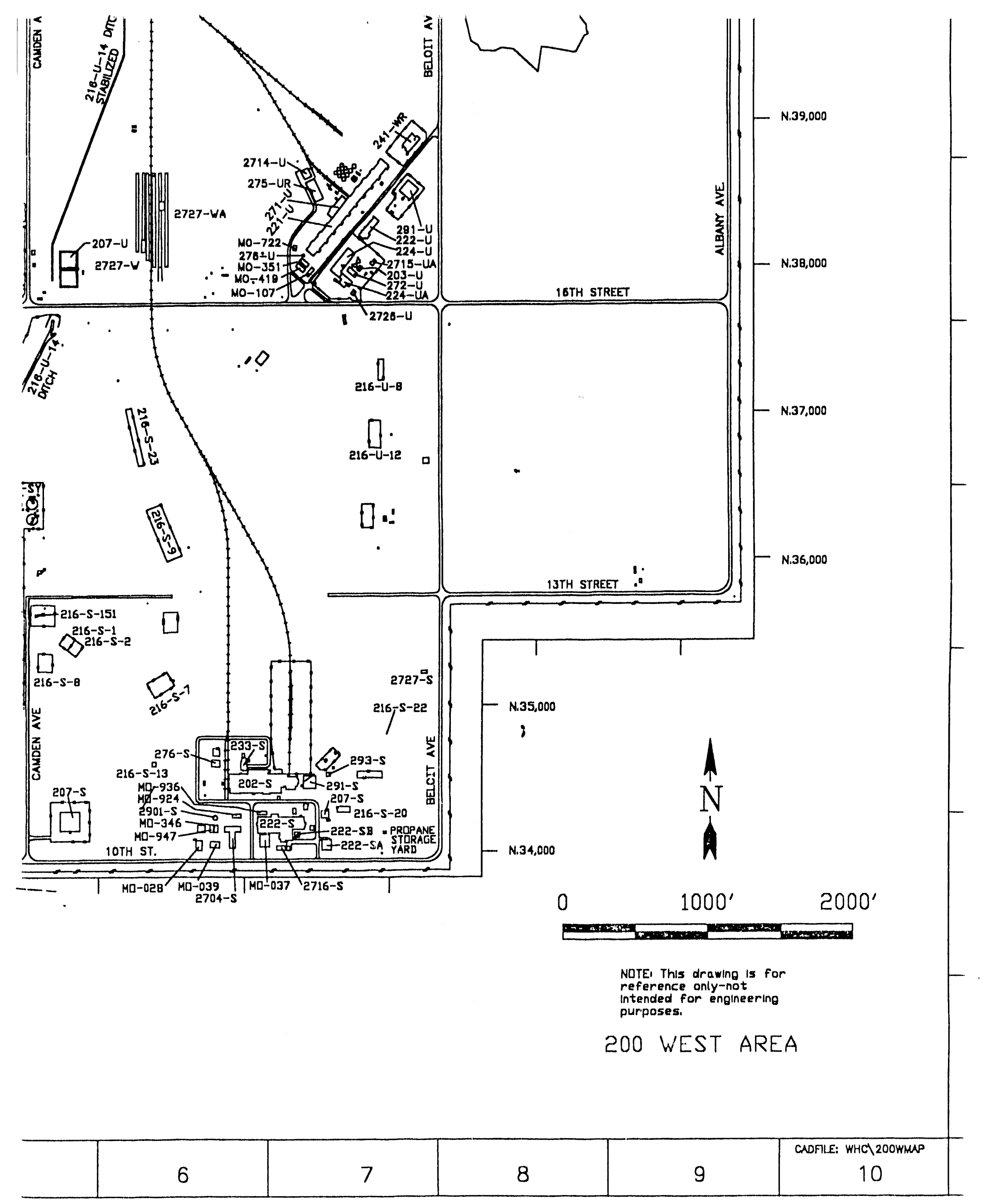




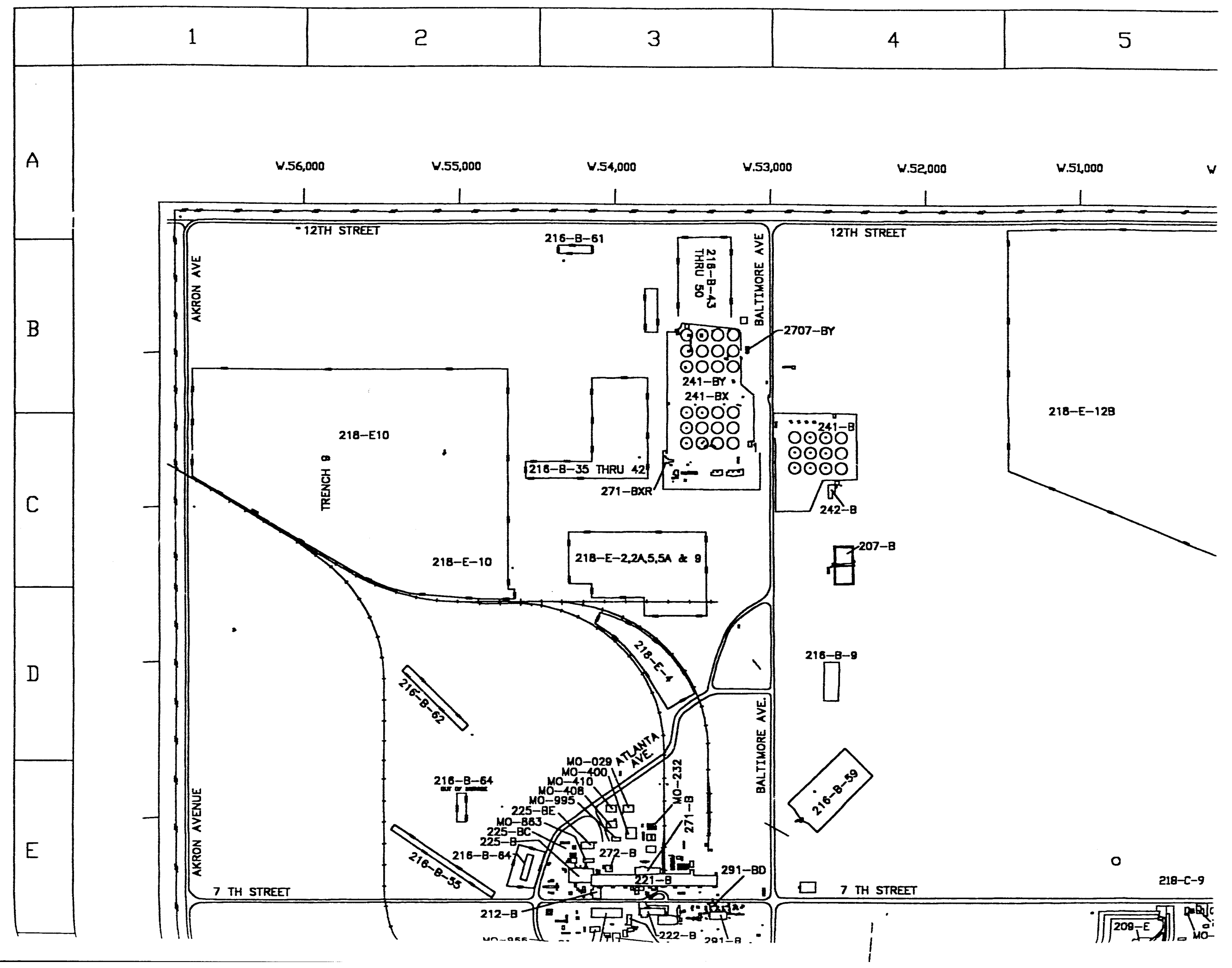




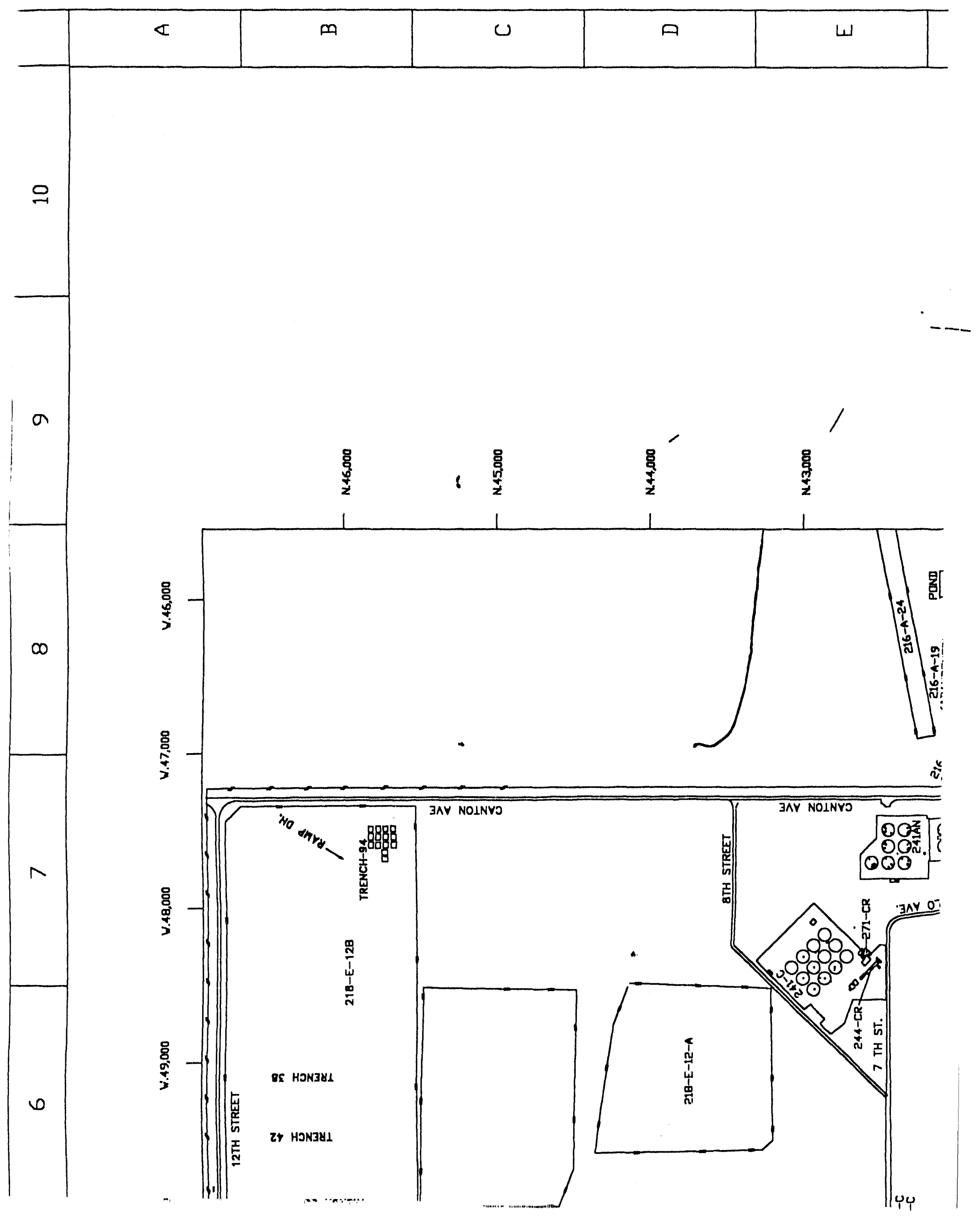




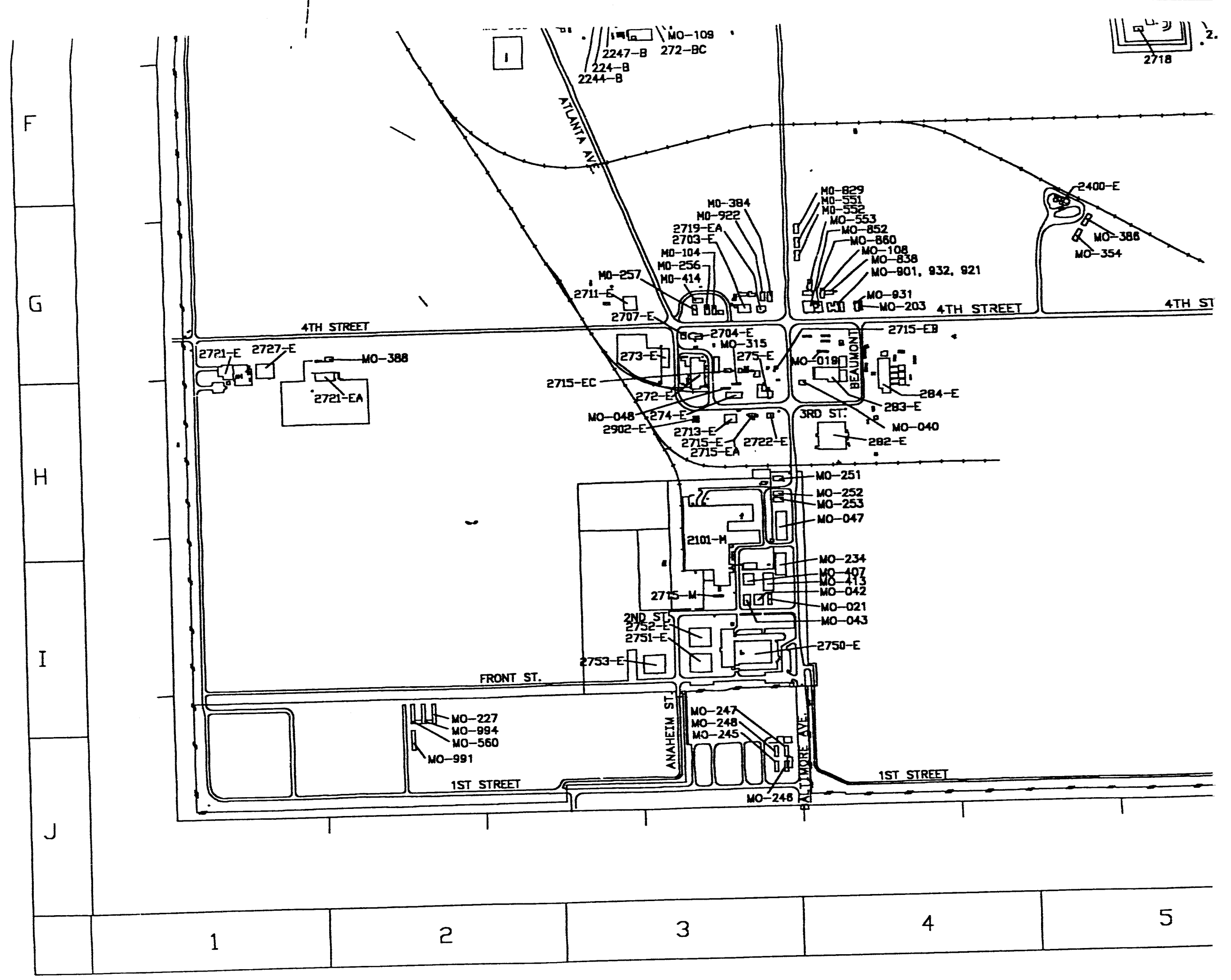




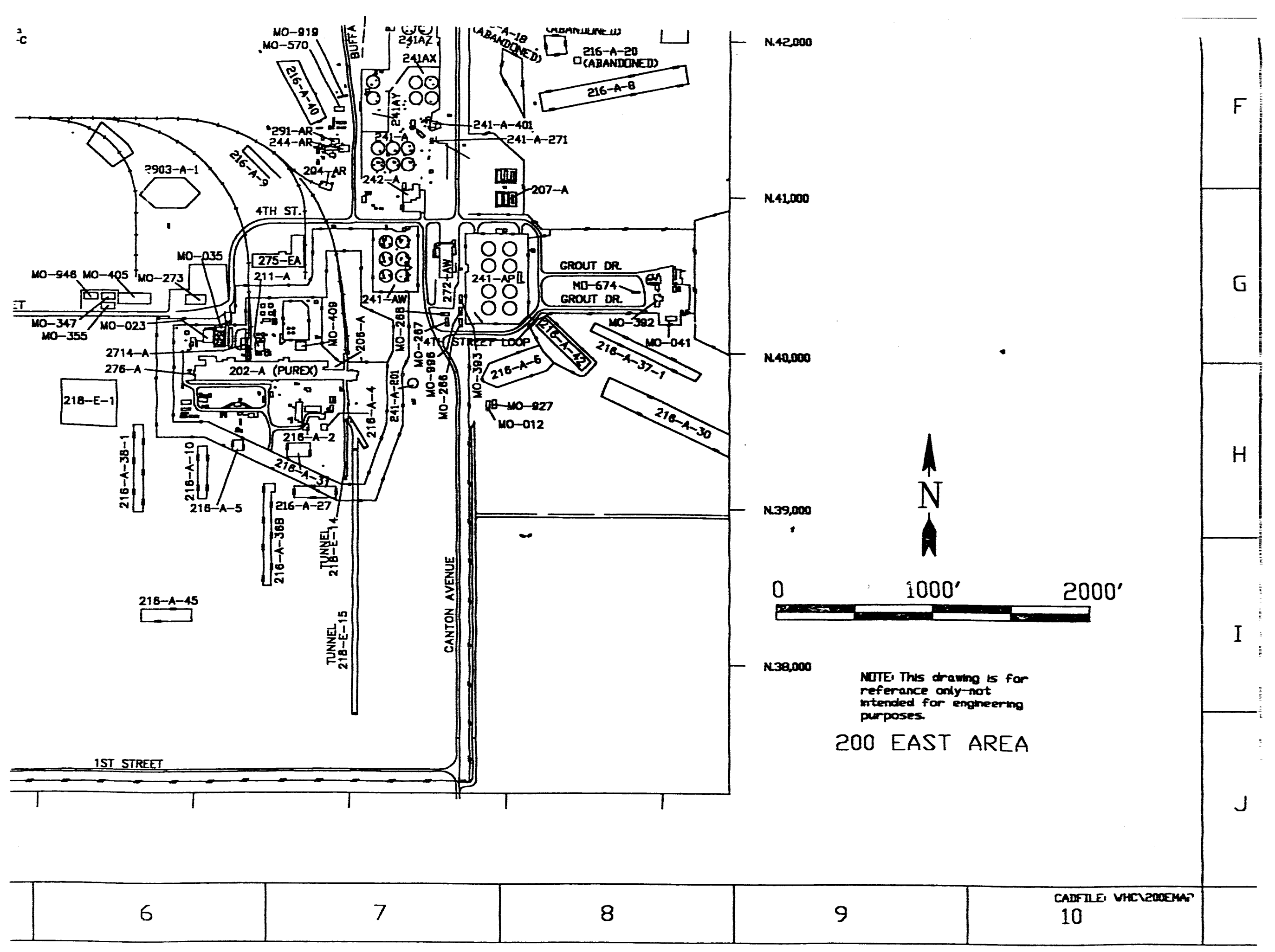



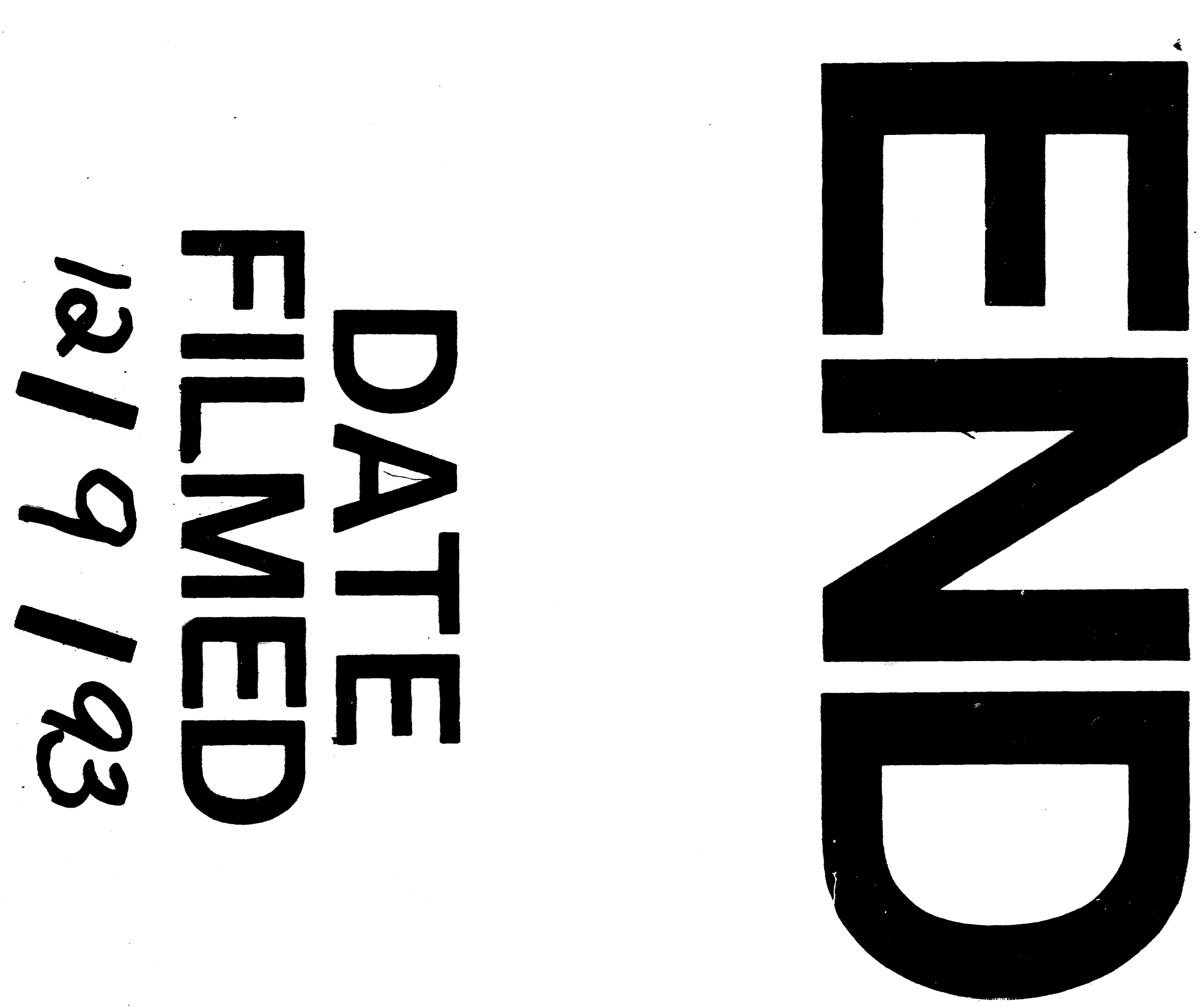
